From Goodwill to Grunge:

Secondhand Consumerism in the Twentieth-Century United States

\author{
Jennifer Kathleen Le Zotte \\ Niceville, Florida
}

B.S. University of Florida, 2000

M.A. University of Florida, 2007

A Dissertation presented to the Graduate Faculty of the University of Virginia in Candidacy for the Degree of

Doctor of Philosophy of Arts

\title{
Department of History
}

University of Virginia

August 2013

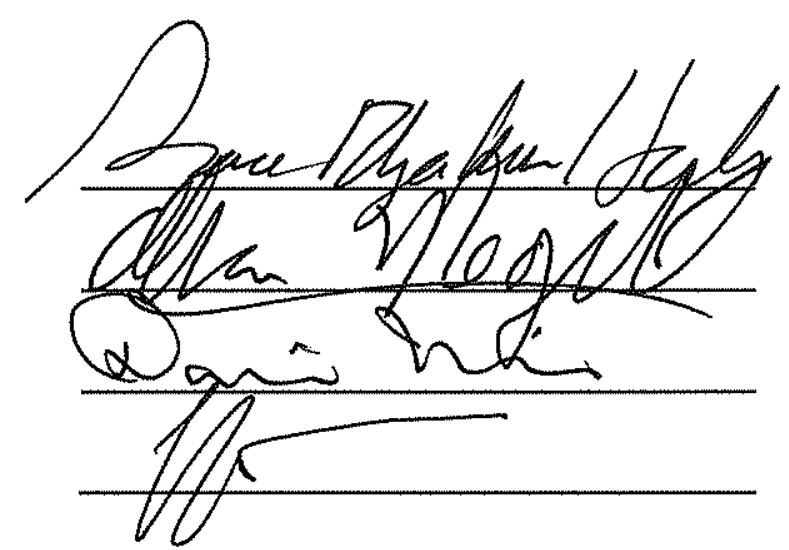




\section{Acknowledgments}

Like every complicated endeavor, this dissertation owes its completion to a host of mentors, friends, and family members. I have many people to thank. Both my work and my now-abiding ardor for historical research and writing are owing to the often unexpected generosity of senior scholars. Brian Ward was the first to formally usher me into the halls of academia. His enthusiasm for my vague idea to write something about flea markets and his subsequent advice and support led to my first graduate degree at the University of Florida, where I also benefitted from the excellent tutelage of professors Jack Davis and Jeffrey Adler.

Like Brian Ward, Grace Elizabeth Hale took a chance on my unformed ideas when she agreed to advise me at the University of Virginia. She never stopped believing in my original vision of secondhand history, even when I was tempted to. I am grateful for Grace's uncompromising approach to scholarly critique, tempered but not encumbered by personal empathy. At the University of Virginia, professors Allan Megill, Cindy Aron, Eric Lott, Alon Confino, and Peter Onuf also helped me along the way, either by reading my work, inspiring my research, or shaping my philosophical approach to academia.

Through long conversations, arguments, drinks, and wrestling, Jon Grinspan, Michael Caires, and Kobi Kabalek helped me realize that I am a historian. Together with Hamutal Jackobson Girshengorn, Eglantine Morvant, and Oscar Ax, these colleagues made me feel a part of an intellectual community in ways I had dreamed of since my childhood. However, too much of a good thing ceases to beneficial, so I am also extremely grateful to the Charlottesville Derby Dames, who, for two glorious, sweaty, bruised and occasionally bloody years, provided the perfect balance to the rigors of writing. I am honored to have known the support of teammates, especially those as strong, multi-talented, and successful as the Dames.

Throughout crafting this dissertation, national and international conferences served me well. I benefitted from the influence and encouragement of several motivating and engaging scholars met at conferences and responsible for expanding my notion of historical work and of American Studies, as well as building my intellectual confidence. Alison Isenberg invited me to serve on my first academic panel, which I attended only two months into my PhD program at the University of Virginia. The experience was validating and exhilarating at exactly the time I otherwise may have succumbed to self-doubt. Subsequent conference interactions with Alison, as well as with Wendy Woloson, Susan Strasser, Helen Sheumaker, Alexandra Palmer, Larry Glickman, and Dierdre Clemente gave me a sense of my work in the context of the growing field of secondhand scholarship and of fashion history. At a conference of the Organization of American Historians, Daniel Horowitz, with academic generosity that continues to astound me, offered his immeasurably valuable guidance. Based only on an obligation to broad intellectual community, Daniel has promptly read everything I sent his way, providing me with expertise in consumer history and a cherished example of collegial kindness. I have come to rely on his advice on a wide array of topics. Quite simply, he is the model of a scholar and a mentor to which I aspire. 
The obliqueness of my topic sometimes required a seeming aimlessness at the archives. I appreciated the patience of Emily Darragh and Julie Le at the Metropolitan Museum of Art, and the archivists at the New York City Municipal Archives, San Francisco Public Library History Center, and the San Francisco GLBT Historical Society, especially Rebekah Kim. Scott Bedio and Susan Mitchem at the Salvation Army National Archives helped me weather several false starts, and even assisted remotely by digitizing and emailing images. I benefitted immensely from the willingness of several people to speak with me directly and at length. Jerry Stokes and Gail Barron the National Flea Market Association shared their flea market expertise and documentation on several occasions, as did Terry Goodson and Ed Collins. Speaking with Cockettes Fayette Hauser and Rumi Missabu was not only very fun but also endlessly fascinating and useful.

For any and all of my accomplishments since pre-adolescence, I owe fortitude and self-confidence to that amazing group of women I've been privileged to know since girlhood. Andrea Fehl and Anne Philip abetted the adolescent obsession with old clothes that foreshadowed this dissertation's topic. Sharing in Lisa Donovan's ambitions (and her unsurpassed baked goods) has made me feel a part of a very elite group. And losing proximity to Erin O'Donnell, whose friendship was essential to my completion of this dissertation-and so much more across these past two decades - will be the hardest part of leaving Charlottesville.

My family has been my greatest motivation. My parents, lifelong teachers and learners themselves, instilled in me intellectual curiosity, love of conversation, and the written word. Sasha Von Dassow, Sumi Von Dassow, Antonia Gardner, Chris Gardner, and Paul Gardner comprised the inspirational and competitive environment into which I was born and have each, in various ways, offered me support and encouragement in my intellectual pursuits, as well as provided comfort during less lofty ordeals. Doctors, musicians, potters, and scientists, my brothers and sisters showed me that there is nothing members of this family cannot do. Antonia, especially, has not only been my best friend and confidante, but if she had not introduced ten-year-old me to the Bargain Box, the shotgun shack that served as the Methodist Church's thrift store in our small hometown, and taught me the fine art of cultivating personal style on a shoestring budget, I may never have been captured by the topic of second hand. All in all, my family's weird sense of clannishness is something I cherish increasingly.

I am delighted to have extended my family in recent years. Everybody who knows me agrees I won the in-law lottery. Ron, Lynn, Jen, Philip, Charlie, and Will Ragain have added to that vital sense of security that makes life so much simpler seeming. Finally, this accomplishment owes most of all to the best life partner I could possible have. Nathan Ragain's scholarly integrity, intellectual devotion, and passion for teaching inspire me to try harder at my craft every day. At the same time, his love, compassion, sacrifice, and domestic care make it logistically possible for me to push myself. His delicious cooking and enduring sense of humor have sustained me in this last year, the hardest and best of my life, during which our inexpressibly wonderful, sweet, and hilarious son, Theodore Givens Ragain, has given everything a fresh and better context. 


\section{Table of Contents}

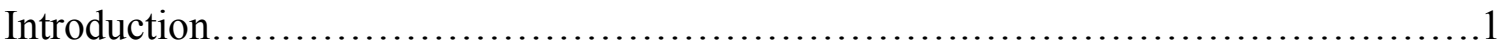

Chapter 1. "Not Charity, But a Chance"

Philanthropic Capitalism and the Rise of American Thrift Stores...............20

Chapter 2. Pushcart Wars and Hoss Mondays:

How Secondhand Saved the Public Marketplace............................57

Chapter 3. "I Couldn't Even Shop When I Wanted To!":

Garage Sales and the Postwar Household................................95

Chapter 4. "A Utopia Would Rise Out of Garbage":

The Radical Fashions of Waste............................................. 133

Chapter 5. Genderfuck and the Boyfriend Look:

Gender Trangression and Secondhand Style................................ 194

Conclusion.............................................................248

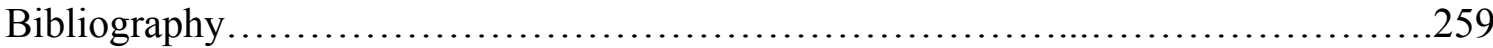




\section{Introduction}

... modern consumer society is symbolized at least as much by the mountains of rubbish, the garage and jumble sales, the columns of advertisements of secondhand goods for sale and the second-hand car lots, as it is by the ubiquitous propaganda on behalf of new goods.

-Colin Campbell

The Romantic Ethic and the Spirit of Modern Consumerism

In 1906, the wistful-eyed, auburn-haired "Commander" of the United States

Salvation Army took center stage at Carnegie Hall. Flanked by a troop of "slum sisters" wearing the torn gingham dresses of tenement wives, Evangeline Booth regaled wealthy theater-goers with tales of the charitable organization's work among the poor, especially her own time spent living in tenements, proselytizing to the unfortunate. Booth glamorized the labor in song and sensationalized the clothing with her demeanor. ${ }^{1}$ An article about "The Commander in Rags" described her outfit as though lingering over the details of a Sarah Bernhardt costume: a slim, little woman, Commander Booth wore "a tartan shawl, a tattered print skirt, and broken-heeled shoes laced with string."2

Booth, the wealthy youngest daughter of the founder of the Salvation Army, frequently used cross-class dress to publicize the Christian humility of the group's evangelical "soldiers," as well as to satisfy a personal desire for drama. ${ }^{3}$ In the musical

\footnotetext{
${ }^{1}$ Diane Winston describes Evangeline Booth's attraction to and romanticization of poverty and her use of what I call cross-class dressing, as well as her important role in the Salvation Army in the U. S. and her reshaping of the group's public image. See Diane Winston. Red-Hot and Righteous: The Urban Religion of the Salvation Army (Cambridge, Harvard University Press, 1999) 143-190. For more on Salvation Army dress, see Jennifer Le Zotte, "'Be Odd': The Contradictory Use of Dress in the Gilded Age Salvation Army," Winterthur Portfolio (Winter 2012, Vol. 47, No. 4).

2 The musical was named "The Commander in Rags" in reference to Booth. See "Miss Booth's Slum Tales Thrill Crowd," New York Times (Jan 29, 1906), p. 9.

${ }^{3}$ Booth's parents once feared she would leave the mission for a life "on stage." P. W. Wilson describes Booth's dramatic inclinations in Wilson, General Evangeline Booth of the Salvation Army (NewYork: Charles Scribner's Sons, 1948), 63-65. For more on Evangeline Booth's life, see Margaret Troutt, The General Was a Lady: The Story of Evangeline Booth (Nashville: A.J.
} 
display at Carnegie Hall, theatrical ragwear made manifest the Salvation Army soldiers' sacrifice of worldly pleasures — including fashion. ${ }^{4}$ Conveniently for both these performances and the slum workers depicted, the Salvation Army had easy access to enormous quantities of old clothes. In 1906, both the Salvation Army and Boston's Goodwill Industries were building charitable salvaging businesses reliant on the acquisition, repair, and resale of secondhand household goods and clothing. Those first "thrift" stores would permanently alter the dynamics between charity, labor, and profit and become a central part of a vast resource for generations of sartorial experimentalists. ${ }^{5}$ Fast-forward eighty-six years to another New York City stage. At Sony Music Studios in November 1993, Nirvana's lead singer Kurt Cobain slouched in the seat of a cheap-looking office swivel chair, strumming his guitar to some of the band's lesserknown songs and covers of Lead Belly and David Bowie. Cobain's unwashed, blond hair skimmed his stubbled chin, his light-colored jeans were stained, and the floppy laces of his classic black Converses were gray. Over a screen-printed Frightwig t-shirt, Cobain wore a pastel-striped, button-down shirt from the perfectly outdated mid-1980s, rumpled

Holman, 1980). Evangeline Booth's views are also reflected in her own writing. See Booth, Evangeline. The Harp and the Sword: Published and Unpublished Writings and Speeches of Evangeline Cory Booth (Salvation Army, Literary Dept., USA Eastern Territory, 1992); Evangeline Booth and Grace Livingston Hill, The War Romance of the Salvation Army, (Philadelphia and London: J. B. Lippincott Company, 1919).

${ }^{4}$ By the end of the nineteenth century, all of the Salvation Army's soldiers were required to wear a uniform, a practice intended to announced separation from secular life, distinction from conventional Protestantism, and unity within the organization. Before the Army itself produced and sold standard uniform garments, Salvationists patched together uniforms from anything that "suggested the soldier": hussars' coats, artillery regiment garb, helmets from the Household Troop Bands, or even just yachting caps - in other words, the first Salvation Army uniforms also used secondhand. See Lt.-Colonel Edith MacLachlan, "The Salvation Army Uniform," (The Salvation Army National Archives [TSANA], uncatalogued, 1977), 5. For more on how religious groups have historically used clothing as "symbolic boundary markers," see Linda B. Arthur, Religion, Dress and the Body (Oxford, New York: Berg, 1999). See also, Le Zotte, "'Be Odd."” ${ }^{5}$ See Edward H McKinley, Somebody's Brother: A History of the Salvation Army Men's Social Service Department (Lewiston: The Edwin Mellon Press, 1986), 158. 
and undone. ${ }^{6}$ A beige-colored woman's cardigan—-lumpy, stretched-out, pilled and fuzzy — topped off the "grunge" look emulated by thousands of enamored viewers of MTV's Unplugged. ${ }^{7}$

For Cobain, grunge (the name given to both the musical and dress styles) referenced his origins from an impoverished rural Washington town and presented a cultivated cynicism about self-image and artistic identity. ${ }^{8}$ Secondhand clothing was so essential to the style that certain Salvation Army stores advertised themselves as the "grunge headquarters." In the 1992 film Singles, which depicts the Seattle-born grunge music scene, the establishing shot zooms past the Space Needle and focuses in on a sidewalk view of an Army-Navy surplus store. ${ }^{10}$ The original adherents of grunge selfconsciously emphasized secondhand, as did the eager, adolescent fans tuned into representative music videos. More properly $u n$-fashion than anti-fashion, grunge even disavowed dissidence, differentiating the trend from its radical older cousin, punk. ${ }^{11}$

\footnotetext{
${ }^{6}$ Frightwig, an all-female, feminist punk band, was suddenly popular after MTV aired the episode of Unplugged in December 1993. See David A. Ensminger, Visual Vitriol: The Street Art and Subculture of the Punk and Harcore Generation (Jackson, Mississippi: University Press of Mississippi, 2011), 188.

${ }^{7}$ Description based on the author's viewing of the episode of MTV Unplugged from which the live album and DVD was recorded. See Beth McCarthy-Miller, director, Nirvana: MTV Unplugged (New York: Geffen Records, 2007).

${ }^{8}$ The term "grunge" was reportedly coined by Mudhoney frontman Mark Arm to describe his band's sound, which leaned on heavy metal but was more stripped down and vocals forward. The music genre would become firmly associated with the angst-ridden, apathetic lyrical minimalism of Nirvana, and the fashion with Cobain. See Kurt St. Thomas, Nirvana: The Chosen Rejects (New York: St. Martin's Press, 2004), 30; see also Kyle Anderson, Accidental Revolution: The Story of Grunge (New York: St. Martin's Press, 2007).

9 The publicity efforts to link grunge and the Salvation Army were local ones-specifically, four stores in Jacksonville, Florida, ran a small campaign touting themselves as "grunge headquarters. The national Salvation Army spokesman responded ambivalently,saying "I'm not so sure the grunge headquarters is what we'd recommend, but if it works. . " from an undated article, "Stores try to cash in on grunge," (TSANA).

${ }^{10}$ Singles, directed by Cameron Crowe (1992; Burbank, CA: Warner Bros.), DVD.

${ }^{11}$ James Truman, editor-in-chief of the men's fashion magazine Details said that grunge "is not about making a statement, which is why it is crazy for it to become a fashion statement." See
} 
Aside from the genre's defining disaffection, many chroniclers of grunge dress focus on the rapid co-optation of street grunge by the fashion world. ${ }^{12}$ Just one year after Nirvana's break-out album, Nevermind — and about a year and a half after Cobain performed live in a vintage floral-print dress—-fashion designer Marc Jacobs shocked his bosses at the preppy fashion house of Perry Ellis by parading a haute couture interpretation of grunge: cashmere thermals, structured "flannel" shirts (actually sandwashed silk), half-laced Doc Martens boots, and crocheted skullcaps. ${ }^{13}$

Grunge music fans reviled high-end fashion's appropriation of their street-born style. The viscerally negative reactions to Jacobs' line reflected a long-standing assumption that secondhand goods exemplified a kind of consumer "authenticity"- that thrift-store shopping, the anti-consumption consumerism, was exactly the opposite of exorbitantly priced runway fashion. ${ }^{14}$ This belief overlooked the fact that many secondhand distribution networks were, in fact, highly profitable businesses that played an intrinsic part in the development of twentieth-century American corporate capitalism. In popular and academic accounts, the supply of secondhand goods is mystified, shrouded by simultaneous assumptions of economic insignificance and moral superiority ${ }^{15}$ This approach ignores the actual political, economic, and cultural effects of

Rick Marin, “Grunge: A Success Story,” The New York Times (November 15, 1992), V1.

${ }^{12}$ See Anderson, Accidental Revolution, 71-132; "Turning Points: Grunge," Voguepedia http://www.vogue.com/voguepedia/Grunge\#cite note-9 (accessed June 1, 2013); see also Susan Orlean, "Breaking Away," Vogue, September 1992.

${ }^{13}$ Marin, "Grunge," V1.

${ }^{14}$ Grace Elizabeth Hale describes how notions of 'authenticity' — along with 'rebellion'—are particularly in flux in the postwar decades, as white, middle-class Americans identify with and redefine themselves as cultural outsiders. This dissertation tracks sartorial representations of this "romance of the outsider." See Hale, A Nation of Outsiders: How the White Middle Class Fell in Love with Rebellion in Postwar America (Oxford, New York: Oxford University Press, 2011). ${ }^{15}$ Reflections on secondhand economies often include them in the broader category of informal economies and assess them as resources for the underprivileged and marginal (many of these theories derived from studying the Latin American context). In the U.S. context, secondhand 
the recirculation of goods.

Over the course of the twentieth century, the sale of secondhand goods and clothing in the United States grew from a series of suspiciously regarded professions on the economic margins of society to include a variety of respectable, multimillion-dollar industries. ${ }^{16}$ At the same time, second-hand goods themselves - especially cloth itemswent from being reviled augurs of disease and destitution to symbols of youthful rebellion and productive creativity. These transformations depended on each other, and they reflected and affected broader changes in commerce, in fashion, in politics, and in art.

This dissertation argues that secondhand exchange in the twentieth-century United States was a major economic tool and defining social mechanism, and not simply a stopgap subsidiary of firsthand commerce. Used goods markets helped to craft the infrastructure of a thriving industrial economy. The philanthropic capitalism of thrift stores, the publically conducted entrepreneurialism of flea markets, and the semi-private intimacy of garage sales permanently altered the U.S.'s commercial landscape. With adept plasticity, secondary economies provided financial opportunities for marginalized groups such as African-Americans and Jews, preserved a waning element of civic

commerce did not remain marginal social or economic territory for long into the twentieth century. For examples of work on informal economies, see Alejandro Portes, Manuel Castells, and Lauren A. Benton, ed., The Informal Economy: Studies in Advanced and Less Developed Countries (Baltimore and London: The Johns Hopkins University Press, 1989); Portes, Alejandro. "The Informal Sector: Definition, Controversy, and Relation to National Development," Review 7, no. 1 (1983): 151-74; Alejandro Portes and Saskia Sassen-Koob, "Making it Underground: Comparative Material on the Informal Sector in Western Market Economies," American Journal of Sociology 93, no.1 (1987).

${ }^{16}$ In 2001, Goodwill Industries reportedly brought in over \$2 billion in revenues. Florida flea market lobbyist Ed Collins reported that the Port Richey, Florida, USA Flea Market sold for $\$ 10$ million in the early aughts. Ed Collins, (Florida flea market lobbyist), interview with the author November 4, 2006. 
interaction within monetary exchange, and provided the raw materials for alternative political and cultural expression.

Especially after the end of World War II, these so-called "shadow economies" gained a substantial, voluntary consumer following. Secondhand markets became an important resource for the public articulation of minority opinions, including those of anti-capitalists, war protesters, advocates of gender and sexuality equality, and environmentalists. Participants in secondhand and underground commerce worked with evolving ideals of fashion, fueled by the growing importance of individual identity and notions of celebrity, to disrupt existing categories of sexuality and gender. Through advocacy for and personal use of used goods, writers, activists, musicians, and other public performers redefined class belonging and its relationship to cultural capital and social mobility. Using consumerism to illuminate and combat social problems stemming from a commodity culture, however, produced contradictory results, which in part accounted for the sartorial irony inherent in later secondhand styles.

This dissertation assumes that "Where did those clothes come from?" and "Why did people wear them?" are equally important questions. The dual examination of buyers and sellers upsets a prevailing tendency of consumer studies to consider supply and demand separately or unevenly. As Bethany Moreton demonstrates, considering businesses in the context of the motivations of employers, the social and cultural lives of workers, and the predilections of buyers creates a fuller understanding of economic trends, labor practices, and consumer responses. ${ }^{17}$ A coordinated look at the supply of and demand for pre-

17 By looking at the success of the world's largest corporation, Wal-Mart, Bethany Moreton describes how a Christian service ethos fueled domestic and global capitalism. See Moreton, To Serve God and Wal-Mart: The Making of Christian Free Enterprise (Boston: Harvard University Press, 2010). 
owned products is especially vital to this study because within certain secondhand markets, the roles of consumer, producer, and supplier were rarely discrete. Thrift-store workers gleaned, repaired, sold, and bought resale goods. Antique collectors frequently became dealers in order to better indulge their passion. Gay rights activists used preowned clothing both to fundraise and to cross-dress.

Grunge dress, with its accessibility, gender-role deviance, cross-class identification, and ironic inflections, referenced a century of secondhand exchange. By relating that history, this dissertation counters a decades-long scholarly privileging of first-hand consumerism. Ever since Thorstein Veblen coined "conspicuous consumption" to apply to the spending habits of the new leisure class at the end of the nineteenth century, consumer scholars have focused on the seemingly never-ending proliferation of new commercial goods. ${ }^{18}$ They have examined changes in the "national character," the psychological impetus to buy, the fantasy-building role of advertisers, the physical spaces of commerce, and the political machinations of the economy and its participants-all in relation to the production or consumption of new goods. ${ }^{19}$ Aside from a handful of

\footnotetext{
${ }^{18}$ See Thorstein Veblen, The Theory of the Leisure Class: An Economic Study of Institutions, (1899; repr. New York: Macmillan Company, 1953), 60-80. For more on Veblen and his economist cohort's analysis of consumerism, see Daniel Horowitz, "Consumption and Its Discontents: Simon N. Patten, Thorstein Veblen, and George Gunton," The Journal of American History 67 (1980): 301-17.

${ }^{19}$ Consumer studies expanded into a wide-ranging field, of which an exhaustive representation is impossible here. In the mid-1950s, concern over the changing "character" of the American people as part of the shift from a producer society to a consumer society generated an array of sociological studies, including David Reisman, Reuel Denny and Nathan Glazer Reisman, The Lonely Crowd: A Study of the Changing American Character (New Haven and London: Yale University Press, 1950); and David Potter, People of Plenty: Economic Abundance and the American Character (Chicago: University of Chicago Press, 1954). Other important (and increasingly pessimistic) sociological works included Herbert Marcuse, One-Dimensional Man (Boston: Beacon Press, 1964); and Daniel Bell, The Cultural Contradictions of Capitalism (New York: Basic Books, Inc, 1976). For assessments of the role of advertising, see Stuart Ewen, Captains of Consciousness: Advertising and the Social Roots of the Consumer Culture (New York: McGraw-Hill, 1976); Roland Marchand, Advertising the American Dream: Making Way
} 
sociologists and anthropologists looking at contemporary examples of flea markets or garage sales, only recently have scholars such as Susan Strasser, Alison Isenberg, and Wendy Woloson offered more than fleeting glimpses into the ineluctable forces of secondhand exchange. ${ }^{20}$

Focusing solely on the effects and influences of firsthand goods exchange creates a skewed perspective of American commercial engagement. When only firsthand goods are

for Modernity, 1920-1940 (Berkeley and Los Angeles: University of California Press, 1985). William Leach, Land of Desire: Merchants, Power, and the Rise of a New American Culture (New York: Pantheon, 1993); and T. J. Jackson Lears, Fables of Abundance: A Cultural History of Advertising in America (New York: Basic Books, 1994). Lizabeth Cohen's A Consumers' Republic: The Politics of Mass Consumption (New York: Knopf, 2003), examines politics through the lens of consumer culture, while several of Kathy Peiss's books give voice to non "leisure" class consumers and consider the influence of the buyer on the commodity. See especially Kathy Peiss, Hope in a Jar: The Making of America's Beauty Culture (New York: Metropolitan Books, 1998); and Kathy Peiss, Cheap Amusements: Working Women and Leisure in Turn-of-the-Century New York (Philadelphia: Temple University Press, 1986.

${ }^{20}$ Work addressing the recirculation of goods is (unlike its subject matter) new, but builds on earlier studies of material value, waste, and consumerism, such as Michael Thompson's seminal theory of "rubbish" and the creation of value. See Thompson, Rubbish Theory (London: Oxford University Press, 1979). Other important theoretical works include Pierre Bourdieu, Distinction: A Social Critique of the Judgment of Taste (Oxon: Routledge, 1984); and Arjun Appaduari, ed., The Social Life of Things: Commodities in Cultural Perspective (New York: Cambridge University Press, 1986).Susan Strasser tracks the changing relationship between materials objects and their owners, emphasizing the ways industrialization effected notions of individual stewardship. See Strasser, Waste and Want: A Social History of Trash (New York: Henry Holt and Company, 1999). Alison Isenberg's forthcoming book uses antique and secondhand trades as a lens for understanding the relationships between the racial reconfiguring of nineteenth and twentieth-century cities and the politics and economy of preserving and redistributing objects of American heritage. From a paper given at the 2013 American Historical Association conference. Isenberg, "Second-hand Cities: Unsettling Racialized Hierarchies," January 2013. Additionally, Briann Greenfield's history of the "invention" of antiques in America explores the high end of secondhand goods value. See Greenfield, Out of the Attic: Inventing Antiques in TwentiethCentury New England (Amherst and Boston: University of Massachusetts Press, 2009. Scholars interested in secondhand in the British context are slightly more prevalent, and their work has influenced this dissertation conceptually. See for example, Beverly Lemire notes the importance of considering the "second tier" of clothing consumption in gauging consumer demand in preindustrial and early industrial England. Beverly Lemire. "Consumerism in Preindustial and Early Industrial England: The Trade in Secondhand Clothes." Journal of Business Studies 27 (1988): 124; Beverly Lemire, "Shifting Currency: The Culture and Economy of the Second Hand Trade in England, c. 1600-1850," in Old Clothes, New Looks: Second Hand Fashion, edited by Alexandra Palmer and Hazel Clark (New York: Berg, 2005); Louise Crewe and Nicky Gregson, SecondHand Cultures (Oxford: Oxford International Publishers, Ltd., 2003). 
considered, thrift appears as a severely diminishing if not absent attribute of consumer culture. ${ }^{21}$ Ideals of frugality and personal stewardship have to some degree taken refuge in the unprepossessing rows of flea market stalls, on the neatly mown lawns at Saturday morning garage sales, and in the heavy-laden shelves of thrift stores.

Secondhand commerce, however, was not without its concessions to the increasingly high standard of living in the U.S., to a time and place where the line between want and need was broad and blurred. Secondhand buying enabled consumers to procure necessities when their incomes could not accommodate firsthand prices. Yet it also helped people who wanted to resist middle-class culture or corporate capitalism to still participate in crafting individual identities based on consumer choices. As Alison Humes admits in her assessment of thrift shops in America, the habit of thrift can become "reflexive instead of effective," resulting in unnecessary and excessive purchases. The hobby of collecting pre-owned objects for aesthetic rather than utilitarian purposes, for example, rose in popularity alongside the growth of secondhand venues. Luxury and thrift are not mutually exclusive, and the irony inherent in grunge style acknowledges the potential extravagance of secondhand consumerism. ${ }^{22}$ Secondhand commerce potentially justified indulgence for many participants; through donations, civically responsible

\footnotetext{
${ }^{21}$ For an example of this declension narrative of thrift, see David M. Tucker, The Decline of Thrift in America: Our Cultural Shift from Saving to Spending (New York: Praeger, 1991). In a compilation of essays on thrift, several historians, including T.J. Jackson-Lears, Jennifer Scanlon, Olivier Zunz, and Lawrence Glickman acknowledge the altered but persistent role for thrift in modern consumer society. See Joshua J. Yates and James Davison Hunter, eds., Thrift and Thriving in America: Capitalism and Moral Order from the Puritans to the Present, (New York: Oxford University Press, 2011). Alison Humes offers an account (framed by personal experience), describing the selfish pleasures of thrift that buying used affords. See Humes, "A Hundred Years of Thrift Shops," in David Blankenhorn, Barbara Dafoe Whitehead, and Sorcha Brophy-Warren, eds., Franklin's Thrift: The Lost History of an American Virtue (West Conshohocken, PA: Templeton Press, 2009), pp. 98-126.

${ }^{22}$ Humes describes how her own "thriftiness" becomes extravagance in "A Century of Thrift Shops," p. 123.
} 
citizens rationalized new purchases based on their forfeiture of used items - after all, last season's discarded shoes were not crowding landfills or taxing municipal incinerators. They were, presumably, going to someone who needed those shoes. In reality, castoff materials in the U.S. reached a monumental tonnage by the end of the twentieth century, and only major exportation of secondhand could accommodate consumer discards.

In order to unravel the array of contradictory impressions of used goods exchange in the U.S., this project explores the origins, growth, and persistence of the three major innovations in twentieth-century secondhand trade - thrift stores, garage sale, and flea markets - along with the use of preowned products by an increasingly diverse body of consumers. Most networks of secondhand distribution are untaxed and unmeasured and so supply researchers with no large, central archives or easily tracked statistics. Inspired by George Chauncey’s innovative source-finding for a "hidden” group, I found evidence for the supply of and demand for these "hidden" economies in small and mostly unplumbed archives (such as those of the Salvation Army), city records, receipts, newspaper articles and classifieds, interviews, memoirs and biographies, political manifestos, literature, sales catalogs, and song lyrics, among many other resources. ${ }^{23}$

\footnotetext{
${ }^{23}$ George Chauncey relied on a vast array of primary sources in order to demonstrate that gay society openly thrived in pre-WWII New York City. See Chauncey, Gay New York: Gender, Urban Culture, and the Making of the Gay Male World, 1890-1940 (New York City: Basic Books, 1994). I apply the methodological approaches from a range of academic disciplines and find inspiration in the works of a diverse group of scholars, including historians such as Kathy Peiss, Daniel Horowitz, Grace Hale, Nan Enstad, Dierde Clemente, and Anne Hollander; sociologists and cultural theorists whose work spans as much time as the dissertation covers, including George Simmel, Angela McRobbie, Wini Breines, Elizabeth Wilson, and Diana Crane; material culture experts like Alexandria Palmer; and historical geographers like Nicky Gregson and Louise Crewe. Together, the materials and analytical approaches represented by this group of scholars introduced me to ways of exploring the relationship between mass culture and quotidian life, methods I have applied to secondhand commerce and style in the context of broader economics and culture.
} 
The dissertation is divided into two, roughly chronological parts, focusing on supply and demand. Part I of the dissertation, "Supplying Secondhand," examines the codification and growth of secondhand sales alongside the maturation of corporate capitalism in the United States. Between about 1894 and 1970, three major innovations in secondhand commerce — thrift stores, flea markets, and garage sales — established a steady supply of readily available used goods.

Chapter 1, “'Not Charity, But a Chance': Philanthropic Capitalism and the Rise of American Thrift Stores," explains how thrift-store proprietors created a sanitized, Christianized alternative to Jewish-run junk shops, one that incorporated Progressive-era ideals of philanthropy, sanitation, and consumer choice. At the turn of the twentieth century, middle-class, native-born Americans distrusted used goods and their systems of distribution. Anti-Semitism fueled their doubts. Typified by pushcart peddlers and pawnshop proprietors, secondhand sellers were disproportionately Jewish, especially as immigration from eastern European countries increased between 1880 and 1920. In addition to racist, xenophobic assumptions of improper business dealings, the goods themselves were viewed as dirty and even dangerous. Among secondhand commodities, cloth materials were especially scorned. As first medical professionals, and then the public, accepted the germ theory of disease, smallpox and yellow fever epidemics were widely attributed to the recirculation of tainted secondhand suits and discarded dresses, presumed to be wares abandoned by their now-dead, previous owners. ${ }^{24}$

\footnotetext{
${ }^{24}$ Medical reports in the late 1800 s contributed the spread of communicable diseases directly to pre-owned cloth items, such as in an 1882 Medical News report that smallpox had been "reintroduced into Jersey County through a suit of second-hand clothes bought in St. Louis." See "News Items," Medical News (Oct. 14, 1882), pp. 41, 16.
} 
Through goods salvaging programs, groups like the Salvation Army and Goodwill Industries provided work, shelter, and clothing for charity-seekers, who then worked to transform unwanted goods into viable consumer products. By bridging the gap between welfare aid and commerce, Goodwill Industries and the Salvation Army created two of the longest-running, largest, and most profitable chain stores in U.S. history. By emphasizing sanitation and Christian philanthropic ideals, thrift stores began to disassociate secondhand goods from Jewish proprietors and communicable diseases.

Chapter 2, "Pushcart Wars and Hoss Mondays: How Secondhand Saved the Public Marketplace," traces the protean development of flea markets. As early as the 1880s, legislation in expanding East Coast cities limited the territory of itinerant vendors, again predominately Jewish. A series of noise regulations, zoning ordinances, and licensing laws in many major cities carved out urban areas where secondhand sales concentrated throughout the twentieth century. These areas eventually assumed the shape of flea markets, with individual stalls rented out to vendors by either a municipal or private property owner. In the 1920 s and 1930s, while these pushcart wars still raged, the advance of chain grocery stores nearly destroyed urban public marketplaces, many of which were built as part of Progressive-era city planning. Used goods gradually filled empty produce stalls, sustaining public marketplaces in the U.S. until a new era of direct food distribution arose later in the twentieth century. Similarly, the addition of secondhand products helped float rural farmers markets through agricultural crises.

Meanwhile, a rise in the popularity of antique and Americana collecting validated secondhand sales venues of all sorts, which helped the informal markets survive when more prosaic items were harder to procure during the Great Depression and World War 
II. Upper-class socialites demonstrated the mounting cultural cachet of used goods by organizing fundraisers in imitation of Paris's popular marché aux puces, from where the name "flea market" originated. Finally, in the 1960s, flea markets secured their position in American consumer culture when entrepreneurs - especially on the west coastcashed in on the craze for old things, staging dozens of "swap meets" in spaces with a variety of alternative identities: abandoned cattle lots, dying drive-in theaters, and football stadium parking lots.

Chapter 3, “'I Couldn't Even Shop When I Wanted To!': Garage Sales and the Postwar Household," contextualizes the rise of garage sales in post-World War II suburbs. Amid the emergence of new forms of first-hand consumerism, such as giant shopping centers and home sales parties, resale did not fade away but adapted to the spatial and social demands of suburbia. Suburban women used the convenience and intimacy of home-held garage sales to expand their earning potential, personalize their surroundings, and to fundraise for political causes and community charity. Suburban men aided in garage-sale success at least incidentally, since the venues provided materials for the increasingly popular trend of do-it-yourself building and home repair. ${ }^{25}$

Part II, "The Use of Used," focuses mostly on the secondhand market's growing consumer base after World War II, by addressing the use of preowned goods by Beats, hippies, anti-war protestors, drag queens, and punk rockers, among others. The resilience of second-hand consumerism amid relative wealth relied upon the principled participation of buyers in the secondary economy, a trend that first emerged in the roaring twenties,

\footnotetext{
${ }^{25}$ For more on the rise of trends in homebuilding and repair, see Steven M. Gelber, Do-ItYourself: Constructing, Repairing and Maintaining Domestic Masculinity," American Quarterly 49.1 (March 1997): 66-112; and Steven Gelber, Hobbies: Leisure and the Culture of Work in America (New York: Columbia University Press, 1999).
} 
when Bohemian modernists incorporated secondhand into their art and dress. Vaudevilleinspired hit songs like Fanny Brice's 1922 "Second-Hand Rose" connected the unconventional Greenwich Village enclave with the surrounding area's Jewishdominated trade in pre-owned consumer items. "Flapper" style, derived from Greenwich Village modernists' dress, introduced Americans to fashionable styles that originally relied upon the creative application of used materials. ${ }^{26}$

During the Great Depression and through the consumer rationing of World War II, many Americans became temporarily and begrudgedly re-accustomed to re-use. In general, secondhand markets stagnated as potential donors were forced to hold onto their stuff. After the war ended, mass migration to suburbs, a leap in consumer spending, and an unprecedented sense of civic duty impelled many Americans to donate outmoded belongings stockpiled through leaner times. Many white, middle-class youth were familiar with secondhand exchange from the perspective of the goods provider. Rummage sales and white elephant sales were frequent forms of community fundraisers, and garage sales originated in postwar suburbs.

The act of thrift-store shopping was in itself deviant. For middle-class youth, becoming the consumer of used goods was a quick rebellion, a way to flip class expectation on its head by assuming the role of the working-class charity recipient or underprivileged thrift-store patron. At the same time, changes in the technology and production of clothing, coupled with the consolidation of a fashion "industry" that offered a consensus as to what was available any given "season" meant that older clothing was more identifiable as such than ever before. The lingering stigmatization of

\footnotetext{
${ }^{26}$ See Deborah Saville, "Dress and Culture in Greenwich Village," in Twentieth-Century American Fashion, pp. 33-56.
} 
used goods, their suddenly increased availability, and their visual distinction from new products set the stage for the radical use of secondhand dress.

To understand use, I focus mostly on the distribution and wearing of secondhand clothing. In writing on fashion and modernity, Elizabeth Wilson describes fashion as an aesthetic enterprise, which, like other artistic forms, performs an ideological task, "to resolve formally, at the imaginary level, social contradictions that cannot be resolved" otherwise. ${ }^{27}$ Clothing, as the most intimate of commodities, and as the literal boundary between private self and public influence, was a key medium by which to imaginatively resolve the conflicting postwar desires for individualism and community. For radical dressers in the postwar era, secondhand materials gave wearers the opportunity to transcend — or at least defy — the rigidity of social categories such as class, race, ethnicity, and gender.

Chapter 4, “'A Utopia Would Rise Out of Garbage': The Radical Fashions of Waste," analyzes the popularization of secondhand in the postwar years, including the radicalization of used goods by anarchists, anti-war activists, feminists, and environmentalists. The increasing collectability of some clothing - the emergence of "vintage" dress - demonstrated that co-optation traveled in various directions. By the time activists adapted secondhand clothing to distinctly political means, upscale, vintage boutiques were already billing used clothing as a very desirable commodity.

The secondhand economies of the 1950s and 1960s provided an enduring but conflicted model of subversive consumerism by critiquing capitalism through acts of acquisition. For the most part, secondhand dressers did not abdicate their role as

${ }^{27}$ Wilson's portrayal of fashion's "elusive double bluffs" heavily informs my analysis of dress. See Wilson, Adorned in Dreams: Fashion and Modernity (Berkeley and Los Angeles: University of California Press, 1985), p. 9. 
consumers, but used it to express social and political opposition. For members of the 1960 's countercultural youth movement, the incorporation of secondhand items into one's wardrobe, like the cross-class action of shopping at secondhand venues, symbolized a generational desire for the breakdown of social, as well as stylistic, categorization. Total corporate co-optation was impossible as long as secondhand was in fact, secondhand, and not a newly produced replica of older styles. By itself, the popularity of used goods did not depict the downfall of its radical purposes.

Chapter 5, "Genderfuck and the Boyfriend Look: Gender Transgression and Secondhand Exchange," demonstrates that secondhand commerce enabled gendertransgressive performances and disrupted accepted gender binaries. In the 1950s and 1960s, thrift stores directly funded gay rights activism while supplying the materials for cross-dressing. At the same time, public displays of avant-garde art and theatrical performances popularized androgyny as part of an anticommercial or trash aesthetic reliant on discarded goods. Influential figures like underground filmmaker Jack Smith and Hibiscus, founder of the psychedelic drag troupe The Cockettes, presented an ambivalent relationship to gay rights, citing anarchic, anti-monetary motivations for avoiding first-hand consumption and for presenting a "queer" appearance deemphasizing sexual preference. Members of The Cockettes commercialized their glitterboy style by using a trash aesthetic with profit-making intentions, helping to style glam rockers and further popularizing gender-ambiguous styles.

But "genderfuck" - a term coined to describe The Cockettes' gender-bending dress - played differently for women than for men. For gender-bending female dressers, the use of the label "boyfriend look" portrayed gender-deviant styles for women as 
reassuringly heterosexual, but without wholly invalidating feminist implications. Punk rocker Patti Smith's iconic style described her complicated sexual self-identity through the cultivation of an androgynous appearance. Pre-owned materials offered an imaginative erotic exchange, and her clothing catalogued the masculine influences on her style and art and set a new standard for creative female genderfuck.

A brief conclusion assesses fashion designer Jean-Paul Gaultier's dismissive remark that "Grunge is nothing more than the way we dress when we have no money." 28 Following the acceptance of gender deviation and secondhand style as shorthand for pop identities, grunge artists adeptly manipulated the creative relationship between dress and performance. Their ironic postures of poverty toward explicitly anti-corporate ends included a self-conscious knowledge of the contradictions inherent in using consumption to oppose consumption.

In a consumerist sphere obsessed with novelty and shaped by planned obsolescence, a thriving second-hand commercial realm seems illogical. Yet, in postwar America, this phenomenon extended from the lowest registers of commerce to the loftiest ranks of artistic production. Reactions to the trade tended toward the extreme and unexamined. On the one hand, loyal vintage dressers posited a "green" approach to fashion, understanding secondhand sales as environmentally friendly and socially superior in its avoidance of direct financial support of companies with unfair labor practices. On the other hand, economists dismissed secondhand exchange as marginal, unmeasurable, and unimportant.

But as Elizabeth L. Cline's recent book Overdressed: The Shockingly High Cost of Cheap Fashion acknowledges, secondhand exchange has become an intrinsic and

${ }^{28}$ Katherine Marin, “Runway Report,” Vogue (July 1993). 
lucrative part of the global economy. By the end of the twentieth century, discarded clothing, much of it donated with charitable intent, far outpaced domestic need. Profitoriented trade organizations like Secondary Materials and Recycled Textiles (SMART) systematized the sorting and redistribution of millions of tons annually of clothing rejected by American thrift store shoppers. ${ }^{29}$ Secondhand clothing exports from the United States grew steadily throughout the second half of the twentieth century. ${ }^{30}$

Secondhand consumerism is exempt from neither the horrors nor the glories of buying and selling. As a cheap and plentiful commercial resource, used goods have encouraged cultural innovation, supported social reform, and supplied marginalized Americans with work and clothing. At the same time, ever-quickening rotations of style and expectations of inexpensive fashion, systems that oppress millions of global workers, are validated by easy systems of disposal for barely worn and low-quality clothing. The persistent myths that used goods exchange is either too inconsiderable to study or morally excepted from the contradictions of corporate capitalism place a limit on understanding the global processes of trade, fashion, and cultural exchange.

\footnotetext{
${ }^{29}$ Cline examines the huge profit-making industries that arose to accommodate the increasing tonnage of castoff clothing in past few decades, and relates the expectation of ever cheaper new clothing to the changes in secondhand clothing trade and recycling. See Elizabeth L. Cline, Overdressed: The Shockingly High Cost of Cheap Fashion (New York: Penguin Group, 2012), pp. 119-137.

${ }^{30}$ For an examination of secondhand exportation to Zambia, see Karen Tranberg Hansen, Salaula: The World of Secondhand Clothing and Zambia (Chicago: University of Chicago Press, 2000).
} 


\section{Part I}

The Supply of Secondhand 


\section{Chapter One}

"Not Charity, But a Chance"":

Philanthropic Capitalism and the Rise of American Thrift Stores, 1897-1930

On 3 May 1884, the Saturday Evening Post carried a short story entitled "The

Blue Silk." The tale's protagonist — the comely, young, buxom blonde Louisa-yearns to accept an invitation to a grand party, but her curmudgeonly father refuses to pay for her "ball frippery." Against the advice of her cousin, who argues that only "second-hand gentility" would resort to such means, Louisa gathers together what little money she has and buys a beautiful, pale blue gown from "the Jewess behind the counter" of a resale shop. ${ }^{2}$ At the party, the gown's train tears; then Louisa overhears the hostess wondering aloud how it is that Louisa would be wearing Emily Lourele's dress! Evidently, the author thought public humiliation not lesson enough, for Louisa later learns that the store where she had purchased the gown has since closed, all of its workers having been stricken with small-pox, initially brought in with the stock that is currently being carted away for disposal. Louisa's household soon succumbs to the illness, she most severely. In the course of its ravages, Louisa loses, along with her social reputation, her fine looks.

In 1902 the Reverend Edgar J. Helms, founder of what would come to be known as Goodwill Industries, set out to collect used goods from Boston's wealthier residents and redistribute them to the city's more needy inhabitants. At the time, he and his congregation at the Methodist Morgan Memorial Chapel had to overcome concerns such as those raised in the Post's cautionary account. Pre-owned clothes, perhaps the most

\footnotetext{
${ }^{1}$ Goodwill's oldest slogan, adopted from an article in Carry On, a magazine published in the interest of wounded soldiers. See Beatrice Plumb, Edgar James Helms, the Goodwill Man (Minneapolis: T. S. Denison \& Company, Inc., 1965), 199; Earl Christmas, House of Goodwill: A Story of Morgan Memorial (Boston: Morgan Memorial Press, 1924), 58.

${ }^{2}$ Percy Herbert, “The Blue Silk,” Saturday Evening Post, 3 May 1884, pp. 63, 42.
} 
intimate of consumer items, were especially suspect. "We have been taught to look askance on discarded clothing,” Helms bemoaned. “'It’s junk,' some have said. They have taught us to abhor it." ${ }^{3}$ Given that goods were abundantly available through catalogs, specialty shops, and department stores, most citizens thought potentially unhygienic secondhand wearables suitable for donating to the poorest of the poor but hardly fit for public sale.

Despite such resistance, Goodwill Industries spread from Boston, throughout New England and beyond. By 1935, it had established ninety-six "thrift stores" in American cities as well as a dozen abroad. Gathering no-longer-wanted articles in designated Goodwill Bags, millions of "altruistic housewives" aided in Goodwill's success. ${ }^{4}$ Salvation Army thrift stores expanded throughout the first part of the century as well, especially in the affluent 1920 s, which suggests that the commercial viability of the secondhand trade did not rely on recessions. At the time of the 1929 stock market crash, thrift store income provided approximately half the annual budget for the eastern Men's Social Service, the large shelter and jobs' program under which the Salvation Army's nationwide thrift store chain operated. ${ }^{5}$ Business in second hand was booming.

Far from simply drifting in the wake of first-hand commercial endeavors such as department stores, thrift stores constituted a deliberate and profitable sea change in Christian-based community outreach. Industrial capitalism and urbanization set the stage for secondhand commerce, but thrift stores (sometimes referred to as "family service

\footnotetext{
${ }^{3}$ Quoted in Christmas, House of Goodwill, p. 55.

${ }^{4}$ In an industry manual, Rev. Edgar J. Helms thanks the thousands of "altruistic housewives" who make Goodwill a success. The Goodwill Industries: A Manual, A History of the Movement, Departmental Methods of Work, Religious and Cultural Activities, Administration and Organization (Boston: Morgan Memorial Goodwill Press, 1935), dedication.

${ }^{5}$ See Edward H McKinley, Somebody's Brother: A History of the Salvation Army Men's Social Service Department (Lewiston: The Edwin Mellon Press, 1986), 86.
} 
stores" or "social service stores") were not direct offshoots of firsthand commercial endeavors. Instead, by deliberately adapting Progressive-era reforms to a workable business model attuned to a new consumer society, the founders of thrift stores brought unprecedented profitability to their Christian-based community outreach and linked charity to capitalism decades before the "nonprofit sector" had been so designated. ${ }^{6}$ Thrift store innovators also established one of the earliest and longest-running chain businesses in the United States. ${ }^{7}$ And yet scholars have generally failed to acknowledge the importance of secondhand stores in Americans' commercial and social lives, even when addressing the institutions responsible for thrift stores' creation. The Salvation Army, for example — an evangelical mission group with eccentric paramilitary uniforms, raucous parades and marching bands, and somewhat progressive gender politics - has been the subject of many excellent studies. ${ }^{8}$ Still, the Salvation Army's thrift stores, which underwrite a substantial portion of its activities, have been neglected, as have the secondhand businesses of Goodwill Industries, of the Catholic Society of St. Vincent De Paul, and of Deseret Industries, organized by the Church of Jesus Christ of Latter-Day

\footnotetext{
${ }^{6}$ McKinley, Somebody's Brother, p. 158, and Judith Sealander, "Curing Evils at Their Source: The Arrival of Scientific Giving," in Charity, Philanthropy, and Civility in American History, ed. Lawrence J. Friedman and Mark D. McGarvie (New York: Cambridge University Press, 2003), p. 222.

${ }^{7}$ The definition of a chain store is that it have at least ten units and a central headquarters. The only chain store established before the Salvation Army that still exists today is the Great Atlantic $\&$ Pacific Tea Company, or A\&P, a supermarket and liquor store chain. A\&P filed for bankruptcy in 2010 and became a private company in 2012. For more on A\&P, see Mark Levinson, The Great A\&P and the Struggle for Small Business in America (New York: Hill and Wang, 2011). ${ }^{8}$ Studies of the Salvation Army range from the hagiographic to the critical. In addition to his Somebody's Brother, which discusses the Army's Men's Social Service Department, which ran the first thrift stores, Edward H. McKinley has written Marching to Glory: The History of the Salvation Army in the United States of America, 1880-1980 (San Francisco: Harper and Row, 1980).
} 
Saints. $^{9}$

The engines of industrial capitalism and advertising, historians have widely agreed, drove the decisions of firsthand consumers at the turn of the last century, especially those of the less affluent. ${ }^{10}$ Conversely, the success of second-hand commerce illustrates how marginal consumers, especially immigrants, shaped marketing. First, antiSemitism contributed to the disrepute of second-hand sales, a prejudice that worked in the favor of Protestant organizations dealing in salvaged goods. Additionally, new philanthropy targeted immigrants with a view toward maintaining clean, orderly, and fully "American" cities. Teaching American style and habits was part of the Salvation Army's and Goodwill's Americanization and reform programs, which included resale retail as a natural extension of social welfare projects.

Ultimately, thrift store businesses succeeded because they conformed conventional charity and civic responsibility to the conditions of modern consumerism, adapting the virtues of thrift to the rewards of industrial capitalism. The business tactics of and consumer responses to thrift stores defies the assumption that, with the blossoming of modern consumer culture and the rise in standard of living, thrift as an American ideal

\footnotetext{
${ }^{9}$ I focus on the Salvation Army and Goodwill Industries as the earliest and fastest expanding examples of chain thrift stores. By midcentury, however, Catholic counterparts followed much the same trajectory and applied many of the same business tactics in sales and employment. For an anecdotal account of St. Vincent de Paul's thrift store work, see Jane Knuth, Thrift Store Saints: Meeting Jesus 25 Cents at a Time (Chicago: Loyola Press, 2010). Deseret Industries was a post-World War II expansion of the Church of Jesus Christ of Latter-Day Saints' welfare aid. See Leonard J. Arrington and Davis Bitton, The Mormon Experience: A History of the Latter-day Saints (New York: Alfred A. Knopf, 1979), pp. 272-74.

${ }^{10}$ See, e.g., Stuart Ewen, Captains of Consciousness: Advertising and the Social Roots of Consumer Culture (New York: McGraw-Hill, 1976); T. J. Jackson Lears, Fables of Abundance: A Cultural History of Advertising in America (New York: Basic Books, 1994); and Roland Marchand, Advertising the American Dream: Making Way for Modernity, 1920-1940 (Berkeley: University of California Press, 1985). Kathy Peiss makes an excellent case for crediting workingclass buyers with cultural and economic influence over vital changes in dress, media, and entertainment in this period. See, e.g., Kathy Peiss, Cheap Amusements: Working Women and Leisure in Turn-of-the-Century New York (Philadelphia: Temple University Press, 1986).
} 
lost popular favor. Rather than positing a necessary opposition between the goal of acquisition and the value of frugality, the growth of thrift stores underlined how successful marketing techniques, both in favor of new and used products, often relied on an appeal to fiscally sensible shopping in order to encourage consumer participation.

\section{Charitable Salvaging: "Saving the Waste in Men and Things"}

As early as the colonial era, writers, politicians and other vocal critics denounced used goods sales along with other alternative commercial modes, asserting that auctions, vendues, pawnshops, and peripatetic peddling relied on impulse and falsely generated excitement. The goods themselves were assumed undependable, unhygienic, and even dangerous. ${ }^{11}$ Pawnshops, a hybrid of lending and second-hand trade that matured alongside the formalizing of taxed and measured commerce in the nineteenth century, were even more directly associated with vice and profligacy. ${ }^{12}$ Pawnbrokers usually operated in the same areas as prostitutes, gamblers, and other affiliates of the urban underworld, but offered a necessary service to the working poor as well an unsteady

\footnotetext{
${ }^{11}$ Benjamin Franklin, in "The Way to Wealth," argued that auctioneers led consumers astray by exciting them into spending unwisely. However, many land-locked colonists only had access to foreign-made laces, fineries, ribbons, and delicate housewares after these products passed through portside hands. In order to participate in the growing transnational consumer culture, they relied on auctions and vendue sales, which resembled a mix of modern-day flea markets and auctions. For more on Franklin's criticisms of auctions, see Benjamin Franklin, The Way to Wealth (1758; repr. New York: New York Association for Improving the Condition of the Poor, 1848) p. 8; Joanna Cohen writes on the role of auctions in the Early American Republic. For more on early American consumerism, see Cohen, "The Right to Purchase Is as Free as the Right to Sell": Defining Consumers as Citizens in the Auction-house Conflicts of the Early Republic," Journal of the Early Republic 20.1 (Spring 2010): 25-62; T.H. Breen, The Marketplace of Revolution: How Consumer Politics Shaped American Independence (Oxford: Oxford University Press, 2004), pp. 140-141.

${ }^{12}$ Historian Wendy Woloson argues that pawnshops were as formative to the emergence of capitalism, especially in the final decades of the nineteenth century, as was firsthand wholesale and retail commerce. See Woloson, In Hock: Pawning in America from Independence through the Great Depression, (Chicago: University of Chicago Press, 2009), pp. 5-6.
} 
crutch for the blankly profligate. Pawnbroking grew together with the development of consumer culture in the nineteenth century, especially in its final decades. Consumers could levy their nicer wares against immediate needs; urban women, particularly, used pawnshops to supplement insufficient wages, allowing them to participate in the broader capitalist market. ${ }^{13}$ Despite this frequent purpose, pawnshops' reputation was overwhelmingly negative.

Anti-Semitism added to the antipathy for pawning. A large percentage of pawnshop owners were Jewish. Jews in America as well as in Europe were often barred from professional vocations and forced into low-status jobs at the margins of the economy, such as secondhand trade. European Jews were especially central to old clothes trade (or "old clo,"” as the peddler's call had it). Early in the nineteenth century, an enormous proportion of the world's increasingly international trade in used clothing cycled through East London's Old Clothes Exchange, a sophisticated system of secondhand trade. By the end of the century, Chatham Street in New York was a similar harlequin collage of used-clothes dealers suiting the working class - no small proportion of their actual wares came by way of London's East Side. ${ }^{14}$

\footnotetext{
${ }^{13}$ Woloson, In Hock, pp. 5-9. Christine Stansell describes how pawning was a common housewives' financial stopgap, used as a lending agency in order to make rent in close months. See Stansell, City of Women: Sex and Class in New York, 1789-1860 (Chicago: University of Illinois Press, 1987), p. 51.

${ }^{14}$ According to Adam Mendelsohn, Chatham Street became so firmly associated with old clothing trade areas that similar zones as far away as China were called "the Chatham Street" of the city. See Mendelsohn, “'It's the Economy, Shmendrick': A New Turn in Jewish Studies?" AJS Perspectives (Fall, 2009), 14-17. For more on Europe's secondhand trade, see Madeleine Ginsburg, "Rags to Riches: the Second Hand Clothes Trade, 1700-1978," Costume: The Journal of the Costume Society 14 (London, 1980), 125; and Woloson, In Hock, pp. 16-17. On the economic history of Jews in modern Europe, see Derek Jonathan Penslar and Anthony W. Lee, Shylock's Children: Economics and Jewish Identity in Modern Europe, (Berkeley and Los Angeles: University of California Press, 2001), pp. 16, 20.
} 
Between 1880 and 1920, the secondhand trade burgeoned along with an unprecedented influx of immigrants. Before the 1880s, the majority of America's newcomers were from Germany, Ireland, and Great Britain, but after 1900, the numbers of incoming Irish and Germans fell, while Italians, Russians, Poles, Greeks, AustroHungarians, and Jews of various nationalities dominated the statistics. The absolute number of immigrants also rose at the same time as this shift. By 1910, almost 15 percent of all Americans were foreign born, with immigrants and their children comprising approximately three-quarters of the populations of Boston, New York, Chicago, and Detroit. ${ }^{15}$ And, according to an 1890 survey of Jewish families in several Manhattan wards, peddling was the second largest occupation, behind tailoring. ${ }^{16}$

Meanwhile, as improved industrial processes produced more new things and as, consequently, their prices dropped, more usable cast-offs were to be had. Pawnshops proliferated as did scrap businesses. Seeing need among new immigrants and the working class as well as opportunity with the abundance of used goods, the Salvation Army and Goodwill Industries seized the moment. Although they would have to combat the secondhand trade's ill repute among potential customers as well as among the middleclass, native-born citizens they targeted for support, the Protestant social activists enjoyed a distinct advantage over independent Jewish entrepreneurs as they appealed to likeminded secular reformers and fellow Christians.

\footnotetext{
${ }^{15}$ Niles Carpenter, Immigrants and Their Children (Washington, D.C.: Government Printing Office, 1927), and David M. Reimers, "Immigrants and Thrift," in Thrift and Thriving in America: Capitalism and Moral Order from the Puritans to the Present, ed. Joshua J. Yates and James Davison Hunter (New York: Oxford University Press, 2011), p. 350.

${ }^{16}$ The survey identified more than 2,440 peddlers. See Daniel Bluestone, "The Pushcart Evil," in David Ward and Olivier Zunz, ed., Landscapes of Modernity: New York, 1900-1940 (Baltimore, MD: Johns Hopkins University Press, 1992), pp. 292-293.
} 
Thrift store proponents could also capitalize on another turn-of-the-century development that was serving to distance secondhand exchange from its negative associations while simultaneously affiliating it with benevolence. In 1900, an author for one of New York's premier weekly journals, The Outlook, announced that a new kind of charity event, the rummage sale, was "sweeping over the United States like a cyclone, carrying all before [it]." A combination of an "Old Curiosity Shop" and "Rag Fair," it would soon outrank all other charity events, the writer predicted, for it could benefit numerous causes, such as church, settlement home, community, and even political interests. ${ }^{17}$ Selling donated and gleaned goods to the public as well as distributing them to the needy thus became a popular tool among activists of various stripes, especially those with limited access to conventional political influence. ${ }^{18}$

Rummage sales had their origins in charity fairs, which as early as 1820 were blending benevolence and commerce. Originally organized around agricultural products or handmade items and comestibles, the largely female-run charity fairs did not feature secondhand goods until industrial production had become efficient and widespread. Once consumers could regularly and economically replace their household and personal items with new goods, they began donating their used materials to charitable organizations, which then circulated them through established networks. ${ }^{19}$ Engaging with a marginal

\footnotetext{
17“"The Spectator," Outlook, 1 December 1900, anthologized in Alfred Emanuel Smith, ed., New Outlook, vol. 66 (New York: Outlook Publishing Company, Inc., 1900), p. 781.

${ }^{18}$ Female African-American activists used turn-of-the-century rummage sales to gain attention for their causes as well as to raise money. See Linda Gordon, "Black and White Visions of Welfare: Women's Welfare Activism, 1890-1945," Journal of American History 78.2 (September 1991): 559-90.

${ }^{19}$ Beverly Gordon, Bazaars and Fair Ladies: The History of the American Fundraising Fair (Knoxville: University of Tennessee Press, 1998), pp. 11-12. See also F. K. Prochaska, "Charity Bazaars in Nineteenth-Century England," Journal of British Studies 16.2 (Spring 1977): 62-84. Though Prochaska's study focuses on England, similar patterns emerged a little later in the U.S.,
} 
trade that had been assumed to be the province of the foreign, the criminal, and the destitute, the largely middle-class and usually native-born women who ran rummage sales — conducted in public, outdoor venues — brought respectability to resale and helped pave the way for innovations such as the Salvation Army's and Goodwill Industries' thrift stores.

Before rummage sales swept the United States, however, the Salvation Army was pioneering charitable salvage work overseas. ${ }^{20}$ Founded in 1865 by former Methodist minister William Booth as the East London Christian Mission, the Army provided food, shelter, and work for indigents who, in turn, repaired donated materials at large factory workhouses. Sober and diligent individuals were sent to rural "colonies," where they were groomed to spread the Christian message abroad. Profits from workers' renovated products helped fund these worldwide missionary pursuits. ${ }^{21}$

The Army sent a small troop of "soldiers" to New York in 1880, and from there Salvation Army outposts soon spread across the United States. Launched in 1897, America's first Army "salvage brigade" operated out of the basement of a New York men's shelter. In exchange for lodging and food, twenty residents with four pushcarts roamed through local neighborhoods asking for scrap paper—which at first accounted for the bulk of the profits - as well as cast-off household goods and clothing, which they sold

as Beverly Gordon verifies. Rummage sales also foreshadowed flea markets, which were not yet popular in the United States.

${ }^{20}$ Like America's charity fairs, England's charity bazaars predated rummage sales. See Peter J. Gurney, "'The Sublime of the Bazaar': A Moment in the Making of a Consumer Culture in MidNineteenth Century England," Journal of Social History 40.2 (Winter 2006): 386-405.

${ }^{21}$ See Diane Winston, Red-Hot and Righteous: The Urban Religion of the Salvation Army (Cambridge: Harvard University Press, 1999), pp. 118-19; for more detail, see Norman Murdoch, Origins of the Salvation Army (Knoxville: University of Tennessee Press, 1996), pp. 146-68. 
to salvage yards or directly to industries. ${ }^{22}$ At this point, the U.S. Salvation Army's operation differed little from scrap metal and junk dealerships of the time, many of which were run by Jewish entrepreneurs, who were disproportionately represented those who founded such businesses between 1865 and the end of World War I.

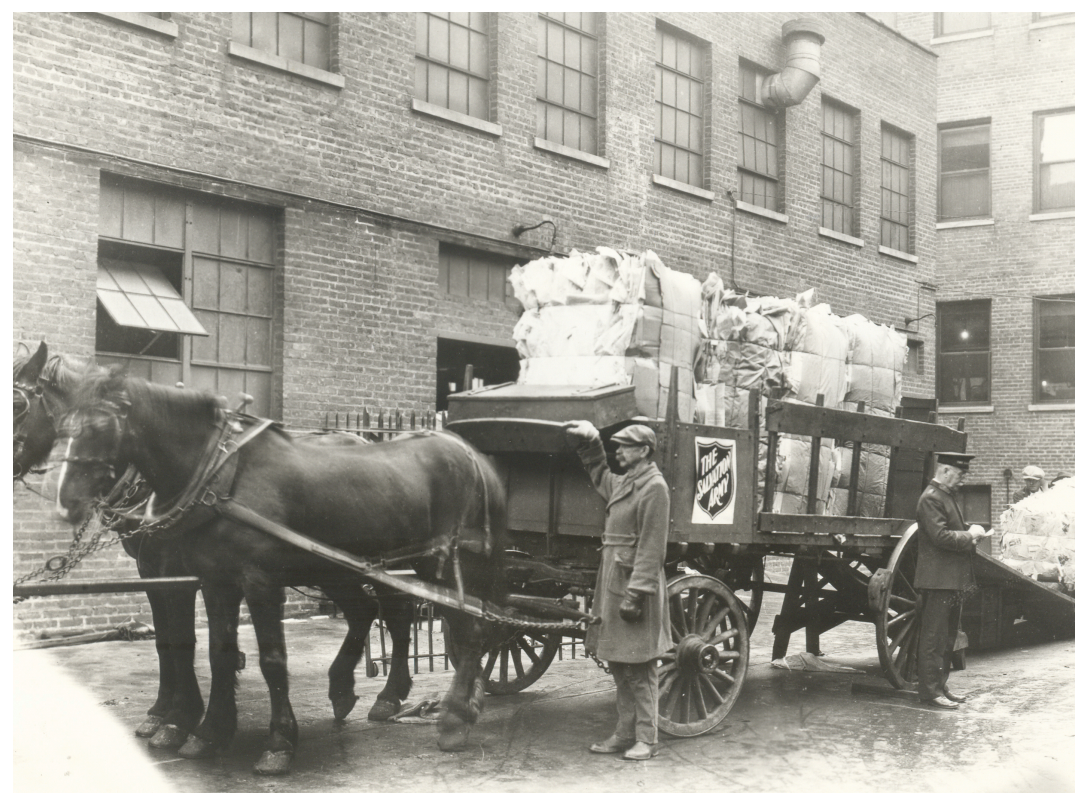

Fig. 1.1. Collected paper products loaded into a Salvation Army horse-drawn wagon, circa 1910. Courtesy of The Salvation Army National Archives (TSANA).

Throughout the nineteenth century, the popular press routinely portrayed Jewish tradesmen as swindlers. At the same time, junk dealers were viewed as a public nuisance, even a moral menace, a group comprised of "foreigners, and classes of collectors who [were] constantly going beyond the limit of the law" and who were, moreover, "low on the scale of ethics and intelligence." 23 Beyond such ethnic prejudices, Americans'

\footnotetext{
${ }^{22}$ A similar program, a Salvation Army "workshop" attached to a shelter called the San Francisco Lighthouse, was launched in that city as early as 1893. Men collected makeshift materials from restaurants, saloons, and even dumps. A "Curiosity Shop" featuring used clothing provided goods and employment. See McKinley, Somebody’s Brother, pp. 24-25, and Susan Strasser, Waste and Want: A Social History of Trash (New York: Henry Holt and Company, 1999), pp. 141-53,15659.

${ }^{23}$ J. P. Alexander, "Sales of Materials," Electric Railway Journal 23 (January 1915): 192-93; Harry H. Grigg and George E. Haynes, Junk Dealing and Juvenile Delinquency, text by Albert E. Webster (Chicago: Juvenile Protective Association, (1919[?]), p. 50; and Carl Zimring, "Dirty Work: How Hygiene and Xenophobia Marginalized the American Waste Trades, 1870-1930," Environmental History 9.1 (January 2004): 87, 89.
} 
increasing understanding of hygiene intensified fears of contagion, which further discredited the practice of collecting discarded goods and reselling salvaged "junk." 24 As new legislation sought to curb the activities of urban scrap dealers, Christian-run salvage ventures that relied on donations (and, thus, were exempt from pushcart regulations aimed at vendors) benefited from these restrictions in places such as New York, Chicago, and Boston.

In addition to sponsoring its own salvage brigades in America, the Salvation Army inspired the creation of other programs that financed their charitable outreach through the sale of salvaged consumer goods. In 1894, Rev. S. G. Smith of The People's Church in St. Paul, Minnesota (which was not affiliated with the Salvation Army) organized what was perhaps the first American thrift store, a small salvage bureau patterned after similar Salvation Army shops in London. In the 1890s, an economic crisis had sunk many people "in want, through no moral or intellectual defects." What they most needed was work, and "in the least conspicuous manner," according to Smith, who credited General Booth with the insight. ${ }^{25}$ Other such programs sprang up across the country. Most were attached to settlement homes and churches and at least loosely tied to the Social Gospel movement.

Also inspired by General Booth, California's West Oakland Settlement began sponsoring a two-day-a-week salvage bureau in about 1899. Well-to-do, native-born, Protestant women volunteered time and donated funds to offset the ill effects of an area

\footnotetext{
${ }^{24}$ Zimring describes eastern European immigrants' involvement in the U.S. waste trades in "Dirty Work," pp. 80-101. Also see his Cash for Your Trash: Scrap Recycling in America (New Brunswick, N.J.: Rutgers University Press, 2000), pp. 5, 46-50, and Woloson, In Hock, pp. 2154. Louis Harap covers literary depictions of Jews in America in The Image of the Jew in American Literature: From Early Republic to Mass Immigration (New York: Syracuse University Press, 2003).

${ }^{25}$ See Eva V. Carlin, “A Salvage Bureau,” Overland Monthly, September 1900, pp. 246-57.
} 
sporting more dirty factories and saloons than playgrounds and reading rooms, "an unsavory spot in moral and material aspects," whose inhabitants, mostly immigrants, lacked the positive attributes of "industry, perseverance, patience, dexterity, economy, cleanliness and thrift." From gardening to children's games, the women organized activities and programs in aesthetically pleasant, well-ordered settings that were designed to instill white, American, middle-class habits and preferences among the settlement's "low-browed" and "ill-favored" residents. ${ }^{26}$ The settlement, whose residents represented more than twenty-one nationalities, mostly Italian and Portuguese, was integrated, but racial condescension and stereotypes were pervasive. ${ }^{27}$ The addition of a small, part-time thrift store tied the settlement's plan to reform its residents by Americanizing them with a strategy to reform the secondhand trade by Christianizing it.

Rev. Helms followed a similar logic when, in 1895, he became pastor of Morgan Methodist Chapel (organized in 1869), located at Shawmut Avenue and Corning Street in Boston's South End. ${ }^{28} \mathrm{He}$ and his wife changed the church's name to Morgan Memorial and reached out to the community — populated largely by Italian, Hungarian, Czech, and Polish newcomers - with childcare, direct almsgiving, and various Americanization programs, such as language training and fresh-air camps for children. The volunteers who delivered the programs - mostly middle-class, Anglo-American women - were motivated by values in keeping with their Puritan heritage and nativist assumptions. ${ }^{29}$

\footnotetext{
${ }^{26}$ Carlin, “A Salvage Bureau,” p. 247, and Marta Gutman, "Inside the Institution: The Art and Craft of Settlement Work at the Oakland New Century Club, 1895-1923," Perspectives in Vernacular Architecture 8 (2000): 248-79.

${ }^{27}$ Gutman, "Settlement Work at the Oakland New Century Club," p. 256.

${ }^{28}$ Subcommittee on Memorial History, Fifty Years of Boston: a memorial volume issued in commemoration of the tercentenary of 1930 (Boston: Tercentenary Committee, 1932), p. 600.

${ }^{29}$ Robert Rollin Huddleston, "The Relatedness of Goodwill Industries and the Christian Church," (Ph.D. diss., Iliff School of Theology, 1959), p. 154.
} 
To enhance their community outreach, church members began collecting clothing for women and children in need. Because the demand for discarded garments among the impoverished was robust, as was the supply of same from the more fortunate, church leaders decided to charge a nominal fee for the goods. As money accumulated, the church hired unemployed women to repair and sometimes repurpose the cloth wares. Word spread, and donations swelled. In due course, Morgan Memorial distributed old food sacks among contributing housewives so that they could more readily set aside and save their unwanted articles for future donation. At first, bags were stamped with "The Morgan Memorial Cooperative Industries and Stores, Inc.”; after 1902, they bore a new, more succinct branding: "The Goodwill Bag.,"30

In 1902, Helms officially launched Goodwill Industries, a secondhand goods program quite similar to the Salvation Army's. Goodwill Industries hired poor and often physically disabled people to assist with collecting cast-off goods, repairing viable items at large factories dubbed "cooperative industries," and selling those refurbished wares at secondhand retail stores. Materials beyond repair were sold to salvage yards. In 1910, the first Goodwill organization outside of Boston was established in Brooklyn, New York, not far from where the pushcarts of the Salvation Army salvage brigades first gathered urban discards. By the early 1920s, Goodwill had a fleet of trucks, like those in Figure 1.2, that amassed unwanted household goods and clothing from more than one hundred thousand homes. Within two decades, the modest Morgan Memorial Chapel had grown

\footnotetext{
${ }^{30}$ Huddleston, “Goodwill Industries and the Christian Church,” pp. 173-74.
} 
into a block-long complex, which included workers' living quarters and a six-story industrial plant. ${ }^{31}$

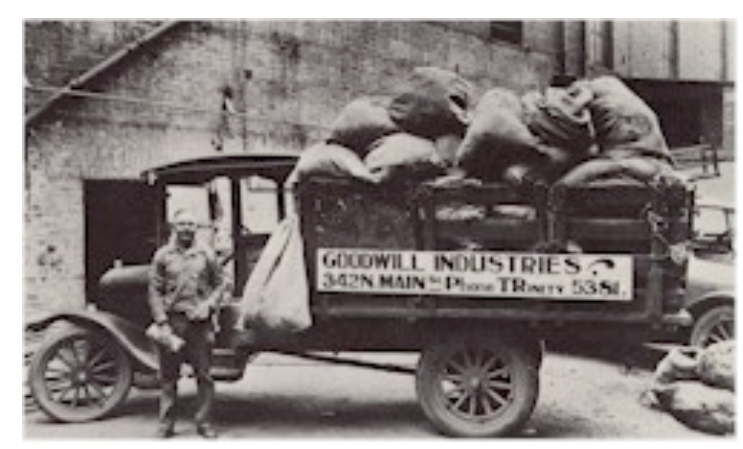

Fig. 1.2. Early Goodwill Industries donation truck. Courtesy of Goodwill Industries International, Inc. Archives.

Comparing the material hand-me-downs that were repurposed in Goodwill's factories with the people who processed them, Rev. Helms promoted his project with the slogan "Saving the Waste in Men and Things.",32 Goodwill advertised its work as restoring the unredeemed to usefulness, making out of the discards of a profligate society productive individuals and newly desirable commodities. "The Goodwill Industries takes wasted things donated by the public and employs wasted men and women to bring both things and persons back to usefulness and well-being. ${ }^{, 33}$ In language that is strikingly similar, the American "commander" Frederick Booth-Tucker likewise characterized the Salvation Army's industrial homes as places where "human wastage" was employed "in collecting, sorting, repairing and selling the material waste." ${ }^{, 34}$

Although Goodwill Industries and the Salvation Army portrayed their burgeoning businesses as social welfare, critics viewed their work as irrelevant to either religious concerns or social uplift. The Salvationists were repeatedly denounced as they spread

\footnotetext{
${ }^{31}$ Christmas, House of Goodwill, pp. 45-47, and Frederick C. Moore, The Golden Threads of Destiny (Boston: Morgan Memorial Goodwill Press, 1952), p. 69.

${ }^{32}$ Christmas, House of Goodwill, p. 143.

${ }^{33}$ Edgar J. Helms, Pioneering in Modern City Missions (Boston: Morgan Memorial Printing Dept., 1944), pp. 71-72.

${ }^{34}$ McKinley, Somebody's Brother, p. 58.
} 
their salvaging efforts across the United States. In 1909, a Catholic priest condemned the Salvation Army's outreach operations. "From a religious organization they have developed into a bunch of junk dealers," he opined. ${ }^{35}$ For such detractors, trafficking in used goods was incompatible with religious goals. Methodists — the Protestant denomination with which both the Salvation Army and Goodwill Industries were at least loosely affiliated - were prohibited from profiting not just from taverns and theaters but also from pawnshops. ${ }^{36}$ Despite the fact that providing the poor with clothing and other necessities had long been the purview of religious charity, selling used goods to the public was still frowned upon as a shady business dealing that sullied all who were involved in it.

\section{Stewardship and Philanthropy: Rebranding Junk Shops as Thrift Stores}

At the turn of the twentieth century, city denizens were throwing away more things than ever before. The large-scale commercial production of items that had previously been fashioned in the home changed people's relationship with material goods; the easier it was to purchase goods, the more people thought of them as temporary acquisitions. At the same time, as urban populations swelled, the size of residential living quarters shrank, as did the areas where unused goods might be stored. As Susan Strasser has concluded, Americans living in the Gilded Age were abandoning personal practices of stewardship. ${ }^{37}$ Responsibility for the stewardship of goods and resources was

\footnotetext{
35“From Religion to Junk," Washington Post, 23 August 1909, p. 12.

${ }^{36}$ David M. Tucker, The Decline of Thrift in America: Our Cultural Shift from Saving to Spending (New York: Praeger, 1991), p. 20.

${ }^{37}$ Strasser, Waste and Want, p. 13.
} 
becoming, instead, the responsibility of governmental agencies and manufacturing interests. ${ }^{38}$

Various waste management industries grew up around the conservation, reduction, and reuse of cast-off materials. For example, the Bessemer converter, which enabled steel mills to mass-produce steel more quickly and more cheaply, raised the demand for scrap iron, an inexpensive source of raw material. In turn, the demand for scrap iron and other industrial remainders and byproducts created economic opportunities for immigrants who had little start-up capital, which contributed to the growth of the above-mentioned Jewish-dominated scrap materials businesses. ${ }^{39}$

Proponents of efficiency continued to advocate long-standing ideals of good stewardship, but they now adapted them to new ideals of giving. Philanthropists, often leaders of corporate capitalism as well, developed and/or supported up-to-date theories on poverty in response to unprecedented urban population growth, which had quintupled nationwide in the last quarter of the nineteenth century and continued to expand through the 1920s. The percentage of those living beneath the poverty line grew but so did the roster of the super-rich. In the late 1870s, approximately one hundred individuals counted themselves millionaires; by 1916, that number had passed forty thousand. Some were millionaires many times over, such as Andrew Carnegie, who in 1901 sold Carnegie Steel

\footnotetext{
${ }^{38}$ Some Progressive-era federal policies, such as the establishment of the Public Lands Commission during President Theodore Roosevelt's administration, demonstrate this shift from private to public responsibility. See Samuel P. Hays, Conservation and the Gospel of Efficiency: The Progressive Conservation Movement, 1890-1920 (1959; repr. Pittsburgh: University of Pittsburgh Press, 1999).

${ }^{39}$ Zimring, Cash for Your Trash, pp. 18-19.
} 
Corporation interests to U.S. Steel for $\$ 447$ million. ${ }^{40}$

The majority of the uberwealthy gave away little in their lifetimes. What they did donate often went to local causes, like building schools or orphanages, which improved only the immediate community. A minority of the new upper class, however, recognized the nation's increasing wealth disparity as an incipient crisis and worried that the struggling masses would threaten the social order. The solution, as proposed by Frederick Gates, John D. Rockefeller Sr.'s chief philanthropic advisor, was scientific givingsystematic, large-scale, highly organized donations designed to better society at large. ${ }^{41}$ Giving was "investing in," as Rockefeller put it, and the goal, Carnegie insisted, was to avoid wasting time, effort, and money on the "unreclaimably poor" and to concentrate, instead, on "stimulat[ing] the best and most aspiring of the poor."

By requiring labor in exchange for shelter-in effect vetting potential clients by testing their willingness to work—and by providing them with useful skills—or so the argument went—-the Salvation Army and Goodwill Industries reflected precepts of systematic or scientific giving. In addition, by charging for donated goods, thrift stores and their related work programs bought new standards of social welfare that valued selfhelp and independence. Goodwill Industries was more directly invested in scientific

\footnotetext{
${ }^{40}$ Charles W. Calhoun, ed., The Gilded Age: Perspectives on the Origins of Modern America, 2nd ed. (Lanham, Md.: Rowman and Littlefield Publishers, Inc., 2007), p. 102; Sealander, "Curing Evils at Their Source," p. 218.

${ }^{41}$ For more on scientific giving, see Sealander, "Curing Evils at Their Source," pp. 218-20.

${ }^{42}$ John D. Rockefeller, Random Reminiscences of Men and Events (New York: Doubleday, Page and Company, 1909), pp. 141-42, 145-47. Andrew Carnegie, "Wealth," North American Review, June 1889, pp. 653-54, and "The Best Fields of Philanthropy," North American Review, December 1889, pp. 682-98; quoted in Robert H. Bremner, Giving: Charity and Philanthropy in Giving (New Brunswick: Transaction Publishers, 1994), p. 159. For more on Carnegie's writings, see his "The Gospel of Wealth" and Other Timely Essays (New York: New York Century Co., 1901); see also Sealander, "Curing Evils at Their Source," pp. 228-37. For more on changes in the structure of philanthropy in America, see Robert H. Bremner, American Philanthropy, 2nd ed. (Chicago: University of Chicago Press, 1988), and David Wagner, What's Love Got to Do with It? A Critical Look at American Charity (New York: New Press, 2001).
} 
philanthropy than were the Salvationists, whose primary motivation was to generate support for their evangelical mission. Salvationists and Goodwill organizers alike, however, had the basic — if often unnamed — ideals of the gospel in mind, as did the era's major capitalist-philanthropists, many of whom—Carnegie, Gates, the Rockefellers, and others-were convinced that the impetus to give was dictated by God. ${ }^{43}$

Although the new philanthropists standardized notions of scientific giving, they were not the first to insist that the reformable poor be differentiated from the permanently derelict. A moral distinction between "victims of circumstance," such as widows and orphans, and those whose poverty was brought on by their own intemperance and idle habits was built into the English poor laws and carried to the New World, especially the New England colonies. Puritans, in particular, emphasized the importance of community charity and the value of hard work. However, for a long time, the distinction between deserving and undeserving poor mattered little because poverty was a relatively minor, contained problem. Even in Boston, screening applicants for aid was not encouraged unless the needy party was not a local inhabitant. Throughout the nineteenth century, the New England states led the charge in charity. But although they boasted the greatest number of associations promoting either charity or philanthropy, the region's longtime Anglo-American residents regarded newcomers seeking support with greater suspicion than ever. ${ }^{44}$

Statisticians, sociologists, educators, and graduate students in a variety of fields studied the causes and implications of poverty, and their findings further legitimated the

\footnotetext{
${ }^{43}$ Robert T. Grimm Jr., "Working with Handicaps: Americans with Disabilities, Goodwill Industries and Employment, 1920s-1970s" (Ph.D. diss., Indiana University, 2002), pp. 24-25, and Sealander, "Curing Evils at Their Source," pp. 226-28.

${ }^{44}$ Robert A. Gross, "Giving in America: From Charity to Philanthropy," in Friedman and McGarvie, Charity, Philanthropy, and Civility, pp. 32-44.
} 
view that direct giving perpetuated rather than alleviated poverty. In the late 1890s, Columbia University's new social science department, working with New York's Charity Organization Society, concluded that environmental circumstances caused 41.8 percent of poverty cases, moral failure or "shiftlessness" 12 percent, and the remainder could be attributed to a combination of causes. ${ }^{45}$ Such calculations, whose very specificity lent them credence, perpetuated distinctions between the "worthy" and "unworthy" poor and encouraged the belief that much poverty could be cured.

Goodwill Industries was so loath to compare its functions to old-fashioned, direct giving charity that at their 1922 annual conference, the company adopted as their national motto, "Not Charity, But a Chance."46 The motto appeared in nearly all company promotional materials, such as the magazine in Figure 1.3, which also features Lady Liberty as Goodwill's benevolent, larger-than-life ambassador. The choice and promotion of the slogan reflected the rise in aggressive advertising, as did the switch from the unappealing moniker "junk shop" to the more uplifting "thrift store." Additionally, redemption through industry was a recurrent theme, one that reflected the authority of scientific philanthropy. Work was the cure for poverty, as Goodwill Industries leaders clearly stated:

Work is the great tonic. The man, broken and discouraged, who is put to mending chairs, repairs his own fortunes and hopes in the process. Each article repaired is made more valuable. To the garment, there is added the labor of the man or woman who works on it. So with people. ${ }^{47}$

\footnotetext{
${ }^{45}$ John Louis Rechiutti, Civic Engagement: Social Science and Progressive-Era Reform in New York City (Philadelphia: University of Pennsylvania Press, 2007), pp. 32-33.

${ }^{46}$ Plumb, Edgar James Helms, p. 199.

${ }^{47}$ Christmas, House of Goodwill, p.58.
} 


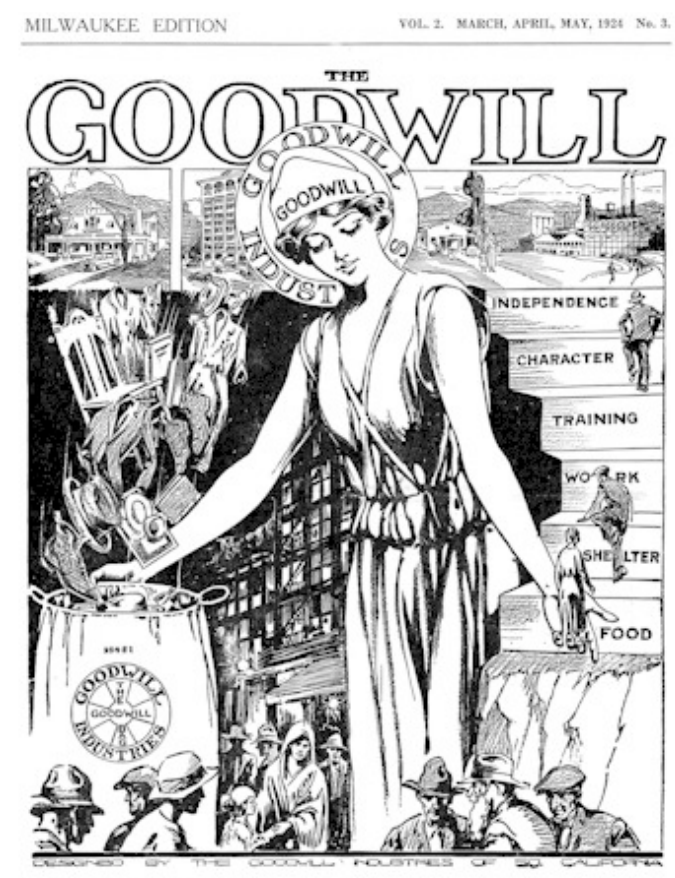

Fig 1.3. Cover of The Goodwill Magazine, Milwaukee edition, (Vol.1, Issue 1, 1924).

\section{NOT CHARITY, BUT A CHANCE!}

Influential religious leaders had long stressed thrift as a core Christian virtue, but thrift is also a basic value of capitalism. ${ }^{48}$ Adam Smith, for example, declared that "Parsimony, and not industry, is the immediate cause of the increase of capital." ${ }^{.49}$ As consuming ready-made goods became an essential activity of everyday life in the late nineteenth century, the concept of thrift was forced to accommodate the impetus to buy. In the 1920s, Harvard economics professor T. N. Carver claimed that "[t]hrift does not consist in refusing to spend money or buy things." In fact, he contended, "the thriftiest people are the people with the highest standard of living." ${ }^{, 50}$ Accordingly, the sort of educated consumer who understood the time-and-money-saving convenience of modern products promoted a brisker economic pace, spurred product innovation, and even

\footnotetext{
${ }^{48}$ Yates and Hunter, intro. to Thrift and Thriving in America, pp. 5-10, 13.

${ }^{49}$ Adam Smith, An Inquiry into the Nature and Causes of the Wealth of Nations (1776), ed. Edwin Cannan (Chicago: University of Chicago Press, 1976), p. 359.

${ }^{50}$ T. N. Carver, "Thrift and the Standard of Living," Journal of Political Economy 28 (November 1920): 284-325.
} 
encouraged the use of consumer credit.

During World War I, as it sought to raise funds for programs geared toward soldiers and their families as well as toward European aid, the U.S. government drew a strong association between "thrift," or saving, and giving. ${ }^{51}$ Mass giving - that is, the cumulative contributions of small-scale donations channeled toward a broad philanthropic application — required a "culture of giving" in which middle- and workingclass citizens would routinely respond to public appeals. The government's strategy of directly soliciting all the nation's citizens was immensely successful, producing "an unprecedented level of giving among a broad cross section of Americans, including recent immigrants." ${ }^{, 52}$ As the public adopted a philosophy of morally influenced personal economics, it contributed more to the country's aggregate growth in charitable giving than did the handful of large-scale donors who had first prompted the shift to scientific philanthropy.

By the 1920s, charitable groups' mass appeals garnered grander responses than ever. For example, a study showed that if 3 percent of a city's residents had supported philanthropic causes in 1900 , by the 1920 s that percentage was likely to have swelled to $35 .^{53}$ The increase in participation was especially dramatic for the laboring classes, even in the heart of the Great Depression. One investigation found that in the 1930s, a full 93

\footnotetext{
${ }^{51}$ Olivier Zunz, "Mass Philanthropy as Public Thrift for an Age of Consumption," in Yates and Hunter, Thrift and Thriving in America, pp. 336-38.

${ }^{52}$ Olivier Zunz, Philanthropy in America: A History (Princeton: Princeton University Press, 2012), pp. 44-46, 340.

${ }^{53}$ Zunz, "Mass Philanthropy as Public Thrift," p. 340.
} 
percent of San Francisco streetcar workers contributed to organized charities. ${ }^{54}$ Some did so through community chests, offshoots of the "war chests" of World War I that collected funds from the sale of Liberty Bonds and other federal instruments. Community chests gathered donations on behalf of hundreds of affiliated local charities, churches, and national charity branches, including the Salvation Army. ${ }^{55}$ A 1935 Goodwill manual suggested that in cities where Goodwill was allied with community chests, the treasurer ought to align the branch's fiscal year with that of the community chest, which suggests that a substantial financial gain was to be anticipated when the confederation divided the funds that had been donated to it. ${ }^{56}$

The thrift store concept accorded well with public sentiment. Even though more commercial items were available for sale and Americans' purchasing power was steadily increasing, consumers continued to associate profligacy with a weak moral character. Across categories of class and ethnicity, and despite the glamour of new and aggressive forms of advertising and marketing, American consumers still critiqued their own and others' materiality. ${ }^{57}$ Through thrift store programs, people could abandon viable clothing and household materials, reassured that they were helping those with fewer means. Passing down her clothing a little sooner than she might have otherwise, the "altruistic housewife" exhibited a virtuous devotion to public thrift that also happily sanctioned her personal indulgence in new acquisitions. Mass philanthropy and the practices of thrift stores thus served to increase buyers' participation in firsthand consumer capitalism.

\footnotetext{
${ }^{54}$ Emily H. Huntington and Mary Gorringe Luck, Living on a Moderate Income: The Incomes and Expenditures of Street-Car Men's and Clerk's Families in the San Francisco Bay Region (Berkeley and Los Angeles: University of California Press, 1937).

${ }^{55}$ Zunz, "Mass Philanthropy as Public Thrift," pp. 336-38, 342-43.

${ }^{56} \mathrm{Helms}$, The Goodwill Industries: A Manual, p. 149.

${ }^{57}$ Daniel Horowitz, The Morality of Spending: Attitudes toward the Consumer Society in America, 1875-1940 (Baltimore: Johns Hopkins University Press, 1985), pp. xvii-xviii.
} 


\section{Scrubology and Soapology: Becoming 100 Percent American}

In addition to persistent notions of good stewardship and thrift, new ideals of sanitation encouraged a rise in thrift store donations, while also dictating the advertisement of salvaging programs' stringent hygiene practices. A woman of middling means in the 1880 s was likely to have reused cloth materials several times over. She mended her husband's shirts, remade them into her children's pinafores, and, finally, used the worn out, unwearable fabric to clean house or to stuff furniture. ${ }^{58}$ The popular acceptance of the germ theory — which had shown that illnesses could be transferred by invisible substances which clung to and bred on materials, especially cloth—altered cleaning and disposal practices, and American women's responsibilities in the home expanded to include a stricter definition of good hygiene for her family. ${ }^{59}$ The affordability of new materials made rampant disposal possible, but the middle-class imperative of domestic cleanliness made it requisite. Even before the in-home reuse of materials lost favor, however, buying secondhand goods was not, in many circles, considered proper. The Saturday Evening Post's cautionary tale of 1884, a summary of which opens this chapter, illustrated the social, physical, and even moral dangers that one risked when buying secondhand. Such anxieties over communicable disease inspired not

\footnotetext{
${ }^{58}$ See Nancy Tomes, The Gospel of Germs: Men, Women, and the Microbe in American Life (Cambridge: Harvard University Press, 1998), pp. 56-57, and Zimring, Cash for Your Trash, p. 40. For more on popular ideas on cleanliness, see Suellen Hoy, Chasing Dirt: The American Pursuit of Cleanliness (New York: Oxford University Press, 1995), and Richard L. Bushman and Claudia L. Bushman, "The Early History of Cleanliness in America," Journal of American History 74.4 (March 1988): 1213-38.

${ }^{59}$ The germ theory was largely but not fully accepted in the scientific community around 1880 . The public did not embrace the precepts until early in the twentieth century. See Phyllis Allen Richmond, "American Attitudes toward the Germ Theory of Disease (1860-1880)," Journal of the History of Medicine 9 (1954): 428-54.
} 
only sorrowful fables but also legislation aimed at curbing informal practices of secondhand exchange.

The increasing quantities of waste generated by expanding urban populations posed real health hazards in Gilded Age cities as municipalities struggled to establish effective garbage and trash disposal systems. After a devastating yellow fever epidemic struck the Mississippi Valley in the 1870s and 1880s, many cities turned their attention to preventing water contamination. In 1895, George E. Waring Jr., a former Civil War colonel and the "greatest apostle of cleanliness," was appointed commissioner of street cleaning in New York City. To help residents understand the need for and to advocate sanitary practices, Waring launched an informational campaign. Among the useful advice he circulated was a plan for profiting from efficient refuse sales rather than consigning unwanted objects to overtaxed city dumps and incinerators. ${ }^{60}$

New York City's Salvationists piggy-backed their own promotional drive on the commissioner's crusade to encourage citizen-based initiatives to enhance municipal cleanliness. Because concerns about contamination and contagion still lingered, the Salvationists published pamphlets explaining their salvaging businesses' ultrahygenic processes for preparing goods for public sale, processes that included "huge laundries working constantly," which thoroughly sanitized donated materials. ${ }^{61}$ Imperatives toward cleanliness permeated the social reform programs underwritten by the thrift stores that Goodwill Industries and the Salvation Army had pioneered. In the 1890s, a new

\footnotetext{
${ }^{60}$ In Garbage in the Cities: Refuse, Reform, and the Environment (rev. ed., Pittsburgh: University of Pittsburgh Press, 2004), Martin V. Melosi offers a history of urban environmental issues and waste management in a broad, world context with illustrative case studies (esp. pp. 41-42). See also, for the American industrial context, Strasser, Waste and Want, p. 125.

${ }^{61}$ See, e.g., "The Evolution of an Idea and a Pushcart: The Story of an Industry Which Remakes Men and Materials," uncatalogued, TSANA.
} 
social department—which would conduct the Salvation Army's thrift store program— adopted as its motto, "Soup, Soap, and Salvation!",62 At the West Oakland Settlement, too, immigrant children were taught cleanliness, a routine carried out in settlement homes across the country. When the settlement's boys had finished practicing military drills and stamping leather, they received rousing instruction in "Scrubology" and "Soapology," borrowing General Booth's terminology. ${ }^{63}$

Good hygiene, modern frugality, individual and community improvement, and personal industriousness were all values emphasized by the developing social sciences and by the new philanthropists. The primary targets of their attention were immigrants. Although "Americanization" is sometimes referred to as a movement, its proponents did not all subscribe to the same tactics; rather, strategies for Americanization ranged along a spectrum from multicultural acceptance to strict, xenophobic demands of absolute assimilation. ${ }^{64}$ Programs abounded for acclimating immigrants to American ways of cooking, cleaning, speaking, dressing, and living. Early on, when operating as Morgan Memorial, Goodwill Industries had provided an array of Americanization programs, such as fresh air camps and language instruction for first-generation children, and it taught "American" cooking and hygiene, as did the Salvation Army. ${ }^{65}$

\footnotetext{
${ }^{62}$ McKinley, Somebody's Brother, p. 34.

${ }^{63}$ Carlin, “A Salvage Bureau," p. 248.

${ }^{64}$ For more on Americanization projects in different contexts, see the essays in George E. Pozzetta, Americanization, Social Control, and Philanthropy (New York and London: Taylor and Francis, 1991). For variants of Americanization, ranging from "liberal" efforts that supported native languages and some cultural customs to the more aggressive, "100 percent Americanism" during the World War I era, see Otis L. Graham Jr. and Elizabeth Koed, "Americanizing the Immigrant, Past and Future: History and Implications of a Social Movement," Public Historian 15 (Fall 1992): 41.

${ }^{65}$ Huddleston, "Goodwill Industries and the Christian Church,” pp. 159-63.
} 
Progressive-era reform groups seeking to impart American priorities also organized "thrift clubs." ${ }^{, 66}$ During World War I, the concept of thrift was expanded beyond the personal realm and into the public as it was tied to notions of patriotism. Liberty Loan drives targeted immigrants, who were encouraged to save money by buying bonds. Posters asked, "Are you 100\% American? Prove it!” The campaign was successful; in September 1918, 46.5 percent of all subscribers were foreign born or directly descended from a first-generation immigrant. ${ }^{67}$

Thrift stores were the consumer's analog to thrift clubs. Shopping was a significant pastime in America, increasingly intrinsic to its culture. Thrift stores extended that culture to and instilled it among impoverished newcomers. When the West Oakland Settlement Home added the salvage bureau to its operation, not all its volunteers were enthusiastic. Still associating immorality and uncleanliness with used goods, they viewed the resale trade as antithetical to their goals of uplift, Americanization, and beautification. Proponents, however, thought that thrift stores would offer the poor a venue where they might participate in and develop the skills necessary to adequately negotiate the increasingly complex American marketplace. Buying was not just a necessity but an aptitude, one best developed and practiced in a setting that emulated the handsome, new department stores springing up in American cities. "Every article of clothing" sold in the thrift store, salvage bureau advocate Eva Carlin pointed out, "is neatly wrapped up and

\footnotetext{
${ }^{66}$ Little attention has been devoted to "thrift clubs" specifically, but they usually functioned in coordination with charitable organizations' other Americanization efforts. See Kenneth Kusmer, "The Functions of Organized Charity in the Progressive Era: Chicago as a Case Study," Journal of American History 60.3 (December 1973): 665.

${ }^{67}$ Zunz, "Mass Philanthropy as Public Thrift for an Age of Consumption," p. 340; Reimers, "Immigrants and Thrift," p. 368; Lizabeth Cohen, Making a New Deal: Industrial Workers in Chicago, 1919-1939 (New York: Cambridge University Press, 1990), p. 77.
} 
tied, so that the transactions assume the dignity of store purchases." ${ }^{\circ 8}$

Thrift store advocates like Carlin faced an uphill battle. Not only did they have to convince reformers, settlement volunteers, and Christian critics about the viability of their proposed enterprise, but potential consumers, too, had to be persuaded to accept the value, practicality, and pleasure of buying pre-owned goods, especially clothing. Immigrants were no exception. Passing pre-worn clothing through kinship networks was common to many newcomers' countries of origin, but the practice did not easily translate into buying strangers' discards, even though recent immigrants well understood the adaptive importance of clothing. Upon arriving in the United States, the first imperative for European, particularly Jewish, immigrants was "to visit the stores and be dressed from head to foot in American clothing." ${ }^{, 69}$ Language skills were necessary for many jobs, but employment and social acceptance were more readily achieved when the applicant's clothing was neat, clean, and not markedly foreign. Thrift stores, which offered inexpensive American wares, would seem to have been ideally equipped to serve the needs of the aspiring immigrant. But young immigrants, women especially, preferred department stores, novel establishments redolent of fashionable modernity and well stocked with ready-made options that enticed new wage earners, over thrift shops, which, no matter how much they gussied up their operations, offered only old clothing stigmatized by a stranger's use. ${ }^{70}$

\footnotetext{
${ }^{68}$ Gutman, "Settlement Work at the Oakland New Century Club," p. 261 (emphasis added). ${ }^{69}$ Mary Antin, At School in the Promised Land (New York: Houghton-Mifflin Company, 1912), p. 30. For more about how Jewish women immigrants responded to American dress, see Barbara A. Schreier, Becoming American Women: Clothing and the Jewish Immigrant Experience, 18801920 (Chicago: Chicago Historical Society, 1994).

${ }^{70}$ Kathy Peiss assesses working women's relationship to ready-made clothing in turn-of-thecentury New York City in Cheap Amusements, pp. 56-87.
} 
The role of clothing in early twentieth-century immigrants' lives, as well as newcomers' sentiments about secondhand, is illustrated in the stories of Russian, Polandborn immigrant Anzia Yezierska. ${ }^{71}$ New clothing was perhaps a greater priority for Jews than for other immigrant groups because their traditional, Old World clothing set them apart at a glance as un-American and non-Protestant. In one of Yezierska's stories, a young Jewish immigrant, Shenah, who believes that a new outfit will help her shed the appearance of foreignness and attract an American man, bemoans her plight. "Woe is me! No mother, no friend to help me lift myself out of my greenhorn rags," she complains. ${ }^{72}$ Shenah's lament speaks to a 1913 Chicago study demonstrating that a newly arrived Jewish girl's stateside relatives considered themselves obliged to buy her American clothing "almost immediately." ${ }^{, 73}$ Shenah, however, with no welcoming relations in the U.S., lacks that advantage.

To acquire the money she needs to buy a cheerful dress and hat decked with imitation cherries, Shenah pawns her "last memory from Russia," a featherbed her mother had made and bequeathed to her. The pawnshop Shenah patronizes is portrayed as a clearly undesirable commercial zone. In one sentence, the space is described as "gloomy," its wares as "tawdry," and the proprietor's face as "grisly. ${ }^{74}$ In Yezierska's stories, virtuous actors like Shenah will reluctantly sell secondhand items to afford new ones, but they will not buy used goods. As the author notes elsewhere, a secondhand store

\footnotetext{
${ }^{71}$ As Katherine Stubbs observes, Yezierska's own "sartorial alienation" stems from her experience as a garment worker and often focuses on ready-made clothing. Much secondhand clothing was likely to be cheap, ready-made discards. See Stubbs, "Reading Material:

Contextualizing Clothing in the Work of Anzia Yezierska," MELUS 23.2, Varieties of Ethnic Criticism (Summer 1998): 157-72.

${ }^{72}$ Anzia Yezierska, "Wings" (1920), repr. in How I Found America: Collected Stories of Anzia Yezierska (New York: Persea Books, 1991), pp. 3-16.

${ }^{73}$ Shreier, Becoming American Women, p. 57.

${ }^{74}$ Yezierska, "Wings," pp. 9, 10-11.
} 
"protrude[s] its rubbish" upon a destitute neighborhood and, thus, becomes one of its more distinctive "banners of poverty." ${ }^{75}$ And so, while middle-class reformers may have considered new immigrants to be the ideal market for thrift stores, immigrants still viewed secondhand shops as disorderly, ugly, and steeped in immorality. ${ }^{76}$ To court their target audience effectively, thrift stores had to adapt.

\section{The New Secondhand: Promoting Fashionable Thrift}

To create a fresh image for used goods, thrift stores incorporated three elements that consumers had come to expect from their familiarity with department stores: ample product choice, attractive display, and a good deal. The Outlook's description of an 1899 rummage sale touched on these key aspects: "a second-hand department store was slowly evolved out of the apparent chaos, with the managers and their friends as saleswomen, and the appeal to the second great human instinct—-that of bargaining—-began."77 Department stores wooed consumers with their vast, carefully presented arrays of fashionable and ever-changing goods, smartly attired mannequins, and helpful but unobtrusive sales staff. As permanent sites, thrift stores were able to emulate firsthand retail more effectively than intermittent, open-air rummage sales. By the eve of the Great Depression, thrift stores' broader acceptability as affordable stand-ins for expensive department stores relied on following department store example, even by advertising their

\footnotetext{
${ }^{75}$ The secondhand shops as "banners of poverty" comes from Anzia Yezierska, Salome of the Tenements (Chicago: University of Illinois Press, 1923), p. 5.

${ }^{76}$ Lizabeth Cohen offers examples of this working-class rejection in home decorations and furnishings in "Embellishing a Life of Labor: An Interpretation of the Material Culture of American Working-Class Homes, 1885-1915," in American Material Culture: The Shape of Things around Us (Bowling Green, Ohio: Bowling Green State University Popular Press, 1984), pp. 158-81.

77،"The Spectator,” p. 781.
} 
wares through conventional retail channels. Given that John Wanamaker, "the greatest merchant in America," was a longtime friend and supporter of the Salvation Army, thrift stores' success was not entirely surprising. Indeed, in the years around World War I, Salvation Army and Goodwill thrift stores matched, or even outpaced, the growth of chain stores such as Woolworth's and A\&P. ${ }^{78}$

But attractive displays and clever advertising were not sufficient to attract and retain a steady clientele. Because fashion trends changed rapidly, the vast majority of donated garments were out of style, and so less likely to be purchased by even marginalized consumers. The garment manufacturing section of Southern California's Goodwill Industries hit upon a solution, which it announced in a report of the 1920s. "Many up to date coats for girls are made of the larger velvet coats of past seasons. Sateen coat linings and skirts are used for bloomers. ... Long and short pants and suits for boys are cut from the wide-gored skirts of styles now extinct."79

In addition to repurposing donated clothing, the Southern California Goodwill staged fashion shows to showcase the stylishness of thrift store garments. Along with the physical items to be had at the thrift store, which were transformed from outdated to chic, the worker and the consumer were metamorphosed from indigent and ill clothed to selfsufficient and fashionable. ${ }^{80}$ In figure 1.4, a Salvation Army pamphlet from the late teens/early 1920s shows a few choice images of "What the camera finds in a Salvation

\footnotetext{
${ }^{78}$ See Winston, The Urban Religion of the Salvation Army, p. 220. For more on the influence of Wanamaker and his department stores on American consumerism, see Leach, Fables of Abundance, p. 32. On the rise of chain stores, see Tracey Deutsch, Building a Housewife's Paradise: Gender, Politics, and American Grocery Stores in the Twentieth Century (Chapel Hill: University of North Carolina Press, 2010), pp. 43-72.

${ }^{79}$ Betty Harris, With Courage Adequate . . With Dignity Intact: The Story of Goodwill Industries of Southern California (Los Angeles: Goodwill Industries of Southern California, 1971), p. 29.

${ }^{80}$ Harris, Goodwill Industries of Southern California, p. 34.
} 
Army Industrial Home and Store.” A venerable-looking older man labors in the “clockmaker's corner," evoking pre-industrial nostalgia, perhaps tapping into the popularity of the Arts and Crafts movement of the time. ${ }^{81}$ A mechanic has a position, and even "men who have no other trade can always sort and bale paper." And in the very center of the pamphlet, a young girl smiles at a newly priced possession held aloft with pride: "A modish little top-coat made from remnants of automobile upholstery."

That alteration involved the same practice of stewardship that nineteenth-century women had performed when they repaired and repurposed their own household items. In the age of industrial capitalism, the stewardship of material goods was adapted to new commercial realities, and thus recodified, at the same time as new populations-both employees and consumers-were drawn into America's free market economy.

\footnotetext{
${ }^{81}$ T.J. Jackson Lears writes on the antimodernist implications of the Arts and Crafts movement in America; see Lears, No Place of Grace: Antimodernism and the Transformation of American Culture, 1880-1920 (Chicago and London: The University of Chicago Press, 1981).

82 TSANA, "What the Camera Finds in a Salvation Army Industrial Home and Store," (pamphlet, uncatalogued, undated).
} 


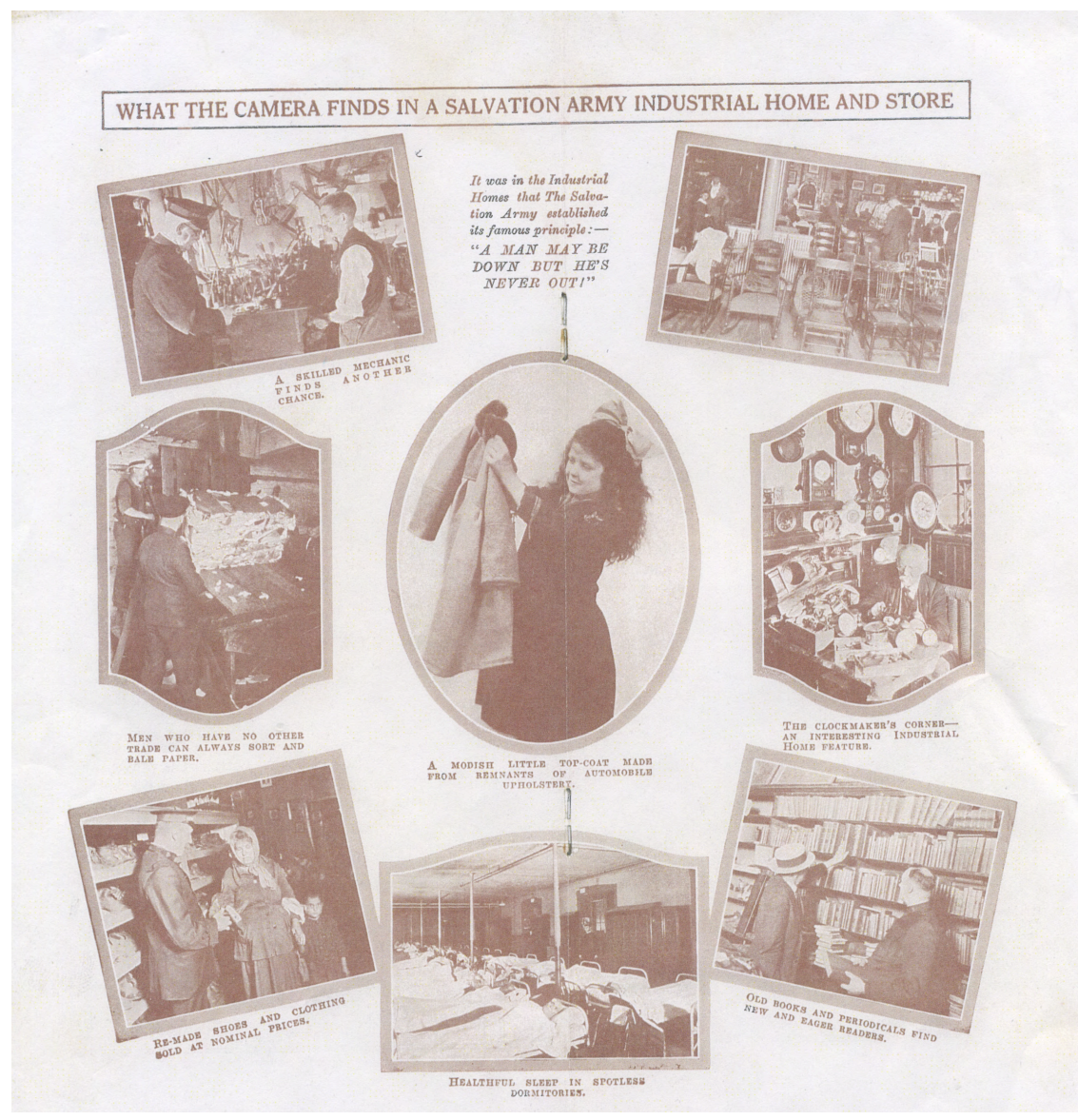

Fig. 1.4.

Promotional pamphlet, circa 1920. Courtesy of TSANA.

A 1902 article on the Salvation Army's Brooklyn salvage store indicated how successful the thrift movement's strategies had already been as it described the remarkable range of customers the stores attracted. They included a struggling mother of nine, a huckster hoping to turn a profit by reselling a good coat, the plain down-and-out, and (the last buyer of the day) a "straight, red-lipped young girl with cool, steady, black eye, who saunters in and leans against the counter, chewing gum and surveying the stock with careful indifference." She chooses a cute pair of bronze slippers to impress the "cream of the ward" at the last Navy Street dance of the season. ${ }^{83}$ The girl does not fit any strict definition of "need," as the article's author makes clear. As a business open to the public, the Salvation Army and Goodwill Industries had no desire to restrict buyers.

${ }^{83}$ "New York's Cheapest Department Store," New York Times, 4 May 1902, p. C1. 
Unlike Reverend Helms's early salvaging initiatives or those of settlement homes, which limited distribution to the "deserving poor," the new chain thrift stores were corporate capitalist endeavors whose inexpensive wares were available to all.

Capitalist interests were not the only ones coloring thrift store operations. Other influences, however, like that of consumer cooperatives, exerted slighter influence than did Carnegie and company. Rev. Helms had direct experience with cooperative models through running the Boston Settlement House and visiting cooperatives in the United States and England - including the original Rochdale Cooperative. The name given to the charter granted the umbrella organization in 1905, "The Morgan Memorial Cooperative Industries and Stores, Inc.," reflected Helms's interest in the contemporary trend of consumer cooperatives in England and America. However, Helms only selectively applied cooperative principles. Some, such as democratic member control, were never followed by the Goodwill Industries. The alliance with the cooperative movement seemed mostly rhetorical. ${ }^{84}$

Even more striking was the fact that beginning in the 1920s, and especially during the Great Depression, Goodwill Industries adopted distinctly Marxist rhetoric. Helms himself professed his desire to aid a "class exploited by the capitalists and despised by organized labor." ${ }^{85}$ By then, most of Goodwill Industries’ lower-level employees were

\footnotetext{
${ }^{84}$ Moore, The Golden Threads of Destiny, p. 68; for more on cooperatives in America, see Florence E. Parker, "Consumers' Cooperation in the United States," Annals of the American Academy of Political and Social Science, 191 (May, 1937), pp. 91-102; Ellen Furlough and Carl Strikwerda, "Economics, Consumer Culture, and Gender: An Introduction to the Politics of Consumer Cooperation," Consumers against Capitalism? Consumer Cooperation in Europe, North America, and Japan, 1840-1990, pp. 5-9; Kathleen Donahue, Freedom From Want: American Liberalism and the Idea of the Consumer (Baltimore and London: The Johns Hopkins University Press, 2003).

${ }^{85}$ Qtd in Ross Warren Sanderson, The Church Serves the Changing City, (New York: Harper Books, 1955), p. 75.
} 
physically or mentally disabled. President Roosevelt's New Deal labeled this group "unemployable" and advocated for the growth of "sheltered workshops" like Goodwill so that such potential workers would not compete on the open market with able-bodied men. However, amateur in its approach, Goodwill in these decades often over-hired, and were unable to provide much income to its workers - at times even just "paying" employees in vouchers for store goods. ${ }^{86}$

Goodwill juggled its ideological sympathies even more awkwardly in a corporate document from 1936: "The Spiritual, Social and Economic Implications of the Goodwill Movement." First the author readily acknowledged Goodwill's purpose as a profitmaking business, especially in the depths of the Great Depression, but he also iterated the group's role within society more generally, as a stop-gap measure for its less valued members. In order to underscore goals of equality, the author quoted a phrase popularized by Karl Marx and used to exemplify Marxist communism. "“From each according to his ability; to each according to his need." ${ }^{87}$ Rhetorically, both cooperative ideals and Marxist philosophies played interesting roles in public representations and the corporate self-understanding of the Goodwill Industries, roles that were never more than nominal.

The Salvation Army was also fleetingly associated with socialism. Friedrich Engels himself wrote, in Socialism: Utopian and Scientific, that the Salvation Army "revives the propaganda of early Christianity, appeals to the poor as the elect, fights

\footnotetext{
${ }^{86}$ Grimm, "Working with Handicaps," pp. 13-15.

${ }^{87}$ The statement of which this is part well expresses the multiple influences on Goodwill: capitalist businesses, charitable intentions, religious dissemination, and disability aide included. Cooperatives, settlement houses, department store operations, and Marxist sentiments all colored the formation of these stores. "The Spiritual, Social and Economic Implications of the Goodwill Movement," Purpose and Policies of Goodwill Industries (Milwaukee: The Bureau of Goodwill Industries and the National Association of Goodwill Industries, 1936), pp. 1-2. Qtd in Huddleston, "Goodwill Industries and the Christian Church," pp. 233-234.
} 
capitalism in a religious way, and thus fosters an element of early Christian class

antagonism." ${ }^{88}$ Salvationists mostly denied such an interpretation, which has none the less found favor in recent historical analyses. Early on, General Booth did admit approval of some elements of socialism, and another important early leader of the group, Frank Smith, helped found the British Labor Party. ${ }^{89}$ Before the thrift store heyday of the postWWII era, when anti-Communism reigned supreme, both Goodwill and the Salvation Army thoroughly shed any hint of such ideologies.

\section{Conclusion: Valuing Business Efficiency over Spiritual Results}

The success of thrift stores made savvy businessmen of old-fashioned almsgiving missionaries. By 1909, Industrial Homes was providing the Salvation Army with nearly $\$ 2$ million annually and comprised the bulk of its $\$ 1.5$ million real estate portfolio. ${ }^{90}$ The mounting importance of maintaining this source of income was reflected in shifting institutional priorities. In 1923, for example, a handbook for evaluating officers valued the "ability to secure business efficiency from men" over "spiritual results in dealing with men." 91

The semantic rebranding of "junk shops" as "thrift stores" signaled that Christianbased social reform groups had, in effect, sanitized secondhand goods, both morally and physically. Much-maligned pawnshops underwent a similar transformation in the mid-

\footnotetext{
${ }^{88}$ The Engels quote is from Frederich Coutts, Bread for My Neighbour: An Appreciation of the Social Influence of William Booth (London: Hodder and Stoughton, 1978), p.11; See also Lillian Taiz, Hallelujah Lads and Lasses: Remaking the Salvation Army in America, 1880-1930 (Chapel Hill: University of North Carolina Press, 2001); and William Kostlevy, Holy Jumpers: Evangelicals and Radicals in Progressive Era America (Oxford: Oxford University Press, 2010), p. 12.

${ }^{89}$ Kostlevy, Holy Jumpers, p. 13; Taiz, Hallelujah Lads and Lasses, p. 107.

${ }^{90}$ Strasser, Waste and Want, p. 143.

${ }^{91}$ McKinley, Somebody's Brother, p. 87.
} 
twentieth century, when semiphilanthropic associations began to compete with independent owners. The most successful of these "benevolent" pawnshops was the Provident Loan Society in New York City, founded in 1929 and bankrolled by business elites such as Cornelius Vanderbilt and J. Pierpont Morgan. ${ }^{92}$

Sociologist Emily Fogg Mead had written that the steady stream of advertisements and novelty goods produced at the beginning of the twentieth century served to awaken in Americans "the ability to want and choose." But in 1901, deprived of the choice and variety that the modern consumer culture afforded, the "lower class [wa]s still the slave of simple and undiversified habits." ${ }^{, 93}$ Thrift stores sought to replicate the "progress in consumption" that aroused and fulfilled wealthier consumers' desires.

Secondhand consumerism mimicked the tactics of mainstream marketing not only to "remake" waste products but to "remake" public perceptions of that waste as well. In the process, goods salvaging programs also remade the men and women associated with that waste. Upper- and middle-class consumers who donated their cast-offs were encouraged to think of themselves as virtuous helpmeets in the Progressive era's reform agenda, while poor, "ethnic," or disabled individuals were transformed into an army of workers as well as a niche market to be tapped. A classic example of doing well while also doing good, the Salvation Army's and Goodwill Industries' salvaging operations changed America's charitable giving as well as its culture of consumption by cunningly creating for the very same artifact both producers and consumers.

\footnotetext{
${ }^{92}$ Woloson, In Hock, pp. 154-58.

${ }^{93}$ Emily Fogg Mead, "The Place of Advertising in Modern Business," Journal of Political Economy 9.2 (March 1901), p. 227.
} 


\section{Chapter Two \\ Pushcart Wars and Hoss Mondays: \\ How Secondhand Saved the Public Marketplace}

In 1937, The Washington Post's society editor boasted the advent of an open-air sale destined to attract "no end" of proper city folk as well as those from "the fashionable hunt country." The market's organizer, known for her "flair for infusing a familiar setup with foreign atmosphere," designed the Middleburg event after Paris's famed marché aux puces (in English, market with fleas). ${ }^{1}$ The avid sportswoman's flea market specialized in new and used boots and saddles, hand-woven, tweed-cushioned dog baskets, and fine linens and glassware. And Bettina Belmont was not alone among the area's debutante set in her secondhand business acumen or her use of French inflections. That year, the Washington Arts Club hosted an entirely secondhand fundraising sale called "Foire aux Croutes" (or "Fair of the Crusts)," versions of which their members had organized annually throughout the 1930 s. $^{2}$

At the same time secondhand sales were attracting the money and attention of D.C.'s high society, New York City Mayor Fiorello LaGuardia was working very hard to limit the presence of roaming junk dealers gathered in New York City's pushcart markets, as part of efforts to formalize the "modern" city's historically street-based foodsales and secondhand economies. ${ }^{3}$ New York City officials had since the last century sought to immobilize these mostly immigrant venders. By the 1930s, city legislation had

\footnotetext{
${ }^{1}$ Hope Ridings Miller, "Bettina Belmont is Set to Open 'Flea Market': Hunt Leaders Expected to Visit Display of Boots, Saddles, Linen, Glassware at Middleburg; Project Patterned After European Idea," The Washington Post, 31 Sept 1937, p. 16.

${ }^{2}$ Miller, "Bettina Belmont is Set to Open 'Flea Market,"” p. 16; For more about fundraising sales in general, see Beverly Gordon, Bazaars and Fair Ladies: The History of the American Fundraising Fair, (Knoxville: the University of Tennessee Press, 1998).

${ }^{3}$ Daniel Bluestone, "The Pushcart Evil," in David Ward and Olivier Zunz, eds., The Landscape of Modernity: New York City, 1900-1940 (Baltimore, Maryland: John Hopkins University, 1992), pp. 308-309.
} 
concentrated once-peripatetic peddlers in certain areas that were either legally designated zones or de facto markets due to certain neighborhoods' poor regulation and oversight.

Both lower Manhattan's oft-reviled pushcart markets and Bettina Belmont's uppercrust hunting-gear soirees were prototypical American "flea markets." Largely due to their definitional capaciousness, classifying "flea markets" is a Sisyphean task. ${ }^{4}$ Historically, hardly any elements evenly applied to all the venues, and even fewer only applied to them. From their earliest inception they were extremely malleable, which accounted for both their persistence and regular predictions of their demise. Unlike thrift stores, there was no discernible date on which the "first" U. S. flea market opened, no formal records of their declared purposes, and no consistent centralized standards. ${ }^{5}$

Some of the earliest examples were continuations of open-air, public food markets. Others developed as the popular and seminal Parisian market did, as studies in negative space, with informal sales consolidating in less-regulated parts of the city or moving outside metropolises. They were the (sometimes illegitimate) offspring of peripatetic peddling, the younger cousins of livestock trade shows, and mid-century, the redemptive siblings of dying drive-in theaters, born to provide a life-saving transfusion of new blood to an institution doomed by television sets and daylight savings time. And, as Miss Belmont illustrates, they were part of upper-crust businesses catering to a rising class of collectors, a category that expanded after the end of World War II to accommodate middle-class buyers and their new hobbyist pursuits of collecting.

\footnotetext{
${ }^{4}$ Some struggling to define flea markets write simply that "you know it when you see it." See Albert LaFarge, U.S. Flea Market Directory, $3^{\text {rd }}$ Edition: A Guide to the Best Flea Markets in All 50 States (New York: St. Martin's Press, 2000), p. ix.

${ }^{5}$ Flea markets did not gain a central organization until 1997, when flea market owner Jerry Stokes formed the National Flea Market Association (NFMA). Information on the formation of the NFMA from NFMA founder Jerry Stokes, interview with the author, November 25, 2006.
} 
In eastern U. S. cities, flea markets sprouted from within the threatened institution of public markets, gradually (though never totally) replacing food with secondhand as grocery stores edged out municipal distribution systems of late nineteenth-century cities. In the less densely populated Midwest and South, monthly court days in town squares provided an informal platform for public trade of all sorts, inviting the eventual addition of secondhand goods, especially after the market in Americana swelled. Finally, in the western states, especially California, where the events were more often referred to as “swap meets," flea market venues co-existed with or replaced various consumer spaces, including cattle lots, drive-in theaters, and football stadium parking lots. ${ }^{6}$

Although many Americans had heard the term "flea market" by the 1920s, the spectacle was nearly unavoidable by the late 1960 s. $^{7}$ Contemporary news reports called the events "a phenomenon of the 60s," and the markets were loosely associated with the drug culture of the time. The concurrent growth of garage sales - the subject of the next chapter-reinforced the trend in secondhand. In fact, more than one curious observer mistakenly saw flea markets as expansions of garage sales. ${ }^{8}$ However, while widespread public visibility of flea markets mounted in the postwar era, fueled by the increasing

\footnotetext{
${ }^{6}$ Data from the NFMA verifies anecdotal evidence for the locations of western U.S. flea markets after 1960. Gail Barron (executive director of the NFMA), interview with the author, October 30, 2006. See also for example, Jack Schermerhorn, "Drive-in Traders Buy, Sell, Swap Everything from Bullets to Bikes," Los Angeles Times, 30 May 1965, p. CS10. In 1969, The Rose Bowl stadium began hosting a monthly flea market in its large parking lots. See for example, Barbara Isenberg, "Garage Sale Gone Big; Monthly 'Swap Meets' Take over Rose Bowl," Wall Street Journal 8 Oct 1970, p. 16.

${ }^{7}$ The estimate of familiarity of the term stems from surveys and research from the latter part of the century but is consistent with its appearance in national newspapers. See Rick Sebak, "A Flea Market Documentary." Pittsburgh: WQED Pittsburgh, Public Broadcasting System, 2001; Stokes, and Barron.

${ }^{8}$ See for example, Robert A. Wright, "See What They Did to the Garage Sale," The New York Times, 15 July 1971, p. 26; Marilyn Hoffman, "Flea Market: Big Business in U.S.," Christian Science Monitor, 10 Sept 1976, p. 2; John Leonard, "Handcraft Swapping at Drive-Ins: A Bit of California Dreaming," The New York Times, 17 January 1976, p. 44; and also in Sebak, "A Flea Market Documentary."
} 
amount of viable discarded secondhand goods and a countercultural fad for antiquated styles, the commercial, social, legal, and cultural roots of these modern bazaars stem from many of the same changes in corporate capitalism, urbanization, and immigration that aided in the establishment of thrift stores in the first decades of the century.

Unlike thrift stores, though, flea markets and their predecessors never dealt exclusively in secondhand goods. Flea markets represented a continuation of nineteenthcentury public markets focused primarily on the food distribution. The origin of U. S. flea markets could be traced to the unrecorded moment when secondhand goods became a critical part of urban public or rural farmers markets, or the also-elusive instant when the name changed. Either way, the addition of secondhand goods sustained public markets as their original purpose faded attendant to the rise in chain grocery stores during the interwar period. ${ }^{9}$ Similarly, secondhand goods extended the services of rural farmers markets in the face of farming crises and diminishing returns on direct-consumer produce distribution. ${ }^{10}$ Secondhand saved the American public marketplace. ${ }^{11}$

\footnotetext{
${ }^{9}$ In his study on the rise and fall of the American public market, James Mayo concludes that while the public markets became economically unviable for both municipalities and private interests by midcentury, they were perceived "as a viable cultural function." See Mayo, "The American Public Market," Journal of Architectural Education (Vol. 45, No. 1, Nov. 1991), p. 41; For a history of the development of grocery stores, see Tracey Deutsch, Building a Housewife's Paradise: Gender, Politics, and American Grocery Stores in the Twentieth Century (Chapel Hill: The University of North Carolina Press, 2010), and for more on the dispute over chain stores in the 1920s and 1930s and oppositional consumerism activism during the Great Depression, see Daniel Scroop, "The Anti-Chain Store Movement and the Politics of Consumption," American Quarterly 60.4 (Dec. 2008): 925-949.

${ }^{10}$ As late as 1971, Jane Pyle called farmers' markets, a term she uses synonymously with public market, a "functional anachronism"- - a designation which has in turn been extended to include flea markets. Pyle charts the history of these markets and their twentieth-century decline. See Pyle, "Farmers' Markets in the United States: Functional Anachronisms," in American Geographical Society 61.2 (Apr., 1971):167-197. In 2001, Allison Brown was more specific in her designation of the markets, and more optimistic about their future. I argue their resurgence is of a piece with the sale of secondhand. See Brown, "Counting Farmers Markets, Geographical Review 91.4 (Oct., 2001): 655-674.
} 
Scholars studying contemporary examples of flea markets admit that "without comparable historical data we can only speculate about why [flea markets] emerged."12 Those historical data form a patchwork portrait of a zigzagging business model, intersecting with or piggybacking onto established venues. For example, in the urban context, in their early stages, the enterprises appear to owe their existence to organized municipal efforts to clean, standardize, and regulate every possible aspect of growing cities. However, popular backlash against those efforts also determined the markets' persistence. The answer lies somewhere in between this push and pull. Flea markets emerged, survived, and finally, flourished through equal measures of participants' adaptability and defiance. The final results varied and changed depending on the cultural and social background of the participants, another protean aspect of the markets.

\footnotetext{
${ }^{11}$ I am taking liberties with the meaning of "public," as most flea markets are not municipal entities, but retain many of the attributes of older government-run and essentially socialized institutions. See Mayo, "The American Public Market," p.42. Also, many “public" markets, too, were funded by, owned by, and provided a profit for private interested as early as the midnineteenth century. A distinction is occasionally made between "municipal" or "quasi-public," in which case the land was city-owned, but the market structures were built by private companies, who managed them and collected revenues for a determined time, usually twenty-five years. See Robert A. Sauder, "The Origin and Spread of the Public Market System in New Orleans," Louisiana, History: The Journal of the Louisiana Historical Association 22.3 (Summer, 1981): 282.

${ }^{12}$ See Russell W. Belk, John F. Sherry, Jr., and Melanie Wallendorf, "A Naturalistic Inquiry into Buyer and Seller Behavior at a Swap Meet," The Journal of Consumer Research 14.4 (1988): 1330. In the 1980s, a body of sociological studies of contemporary swap meets or flea markets and garage sales emerged. See Nabil Y. Razzouk and David Gourley, "Swap Meets: A Profile of Shoppers," Arizona Business 29 (1982): 8-12; Elaine Sherman, Kevin McCrohan, and James Smith, "Informal Retailing: An Analysis of Products, Attitudes, and Expectations," in Advances in Consumer Research, ed. Elizabeth C. Hirschman, Morris B. Holbrook (Provo, Utah: Association for Consumer Research, 1985), pp. 204-208; Cree McCree, "Flea Market," Psychology Today 18 (June 1986): 46-52; Max H. Miller, "Patterns of Exchange in the Rural Sector: Flea Markets Along the Highway," Journal of American Culture 2.3 (1988): 55-59; John F. Sherry Jr., "A Sociocultural Analysis of a Midwestern American Flea Market," The Journal of Consumer Research 17.1 (June 1990): 13-30. Almost all studies on flea markets were produced in the 1980s, after which time followed a lull in the exploration. Robert J. Shepherd's 2008 book When Culture Goes to Market: Space, Place, and Identity in an Urban Marketplace (New York: Peter Lang, 2008) offers a case study of Washington, D. C.’s Eastern Market.
} 


\section{Marché aux Puces: the first "market of the fleas"}

Flea markets were distinguished in part by nomenclature. Americans' first association with the term "flea market" came clothed in Francophilic glamour. The Parisian origins of the name are relevant to, as well as prescient of, the circumstances under which U. S. flea markets emerged in cities. The genesis stories of the Marché aux Puces market and appellation are as numerous as its venders quickly grew to be. ${ }^{13}$ As is often the case, the development of this new mode of secondhand sales coincided with changes in firsthand economies. The flea market's emergence in Paris denoted an important phase in the systematization of primary consumerism - the development of the department store. ${ }^{14}$ Before the late nineteenth-century, professional Parisian peddlers of various goods, including secondhand, both salvaged and hawked their wares in the street, as occurred in many of the world's cities. An estimated thirty thousand chiffonniers (rag pickers), for instance, sold cloth scraps to paper producers. As with charitable salvaging businesses like Goodwill, professional Parisian gleaning involved a good amount of repair and repurposing, though much of it from further down the scavengers' food chain:

\footnotetext{
${ }^{13}$ For example, some say the term originated because looking for coveted goods at such a market is akin to looking for fleas on a dog. See Leavitt F. Morris, "Travel Editor's Diary," Christian Science Monitor 7 Jun 1957, p. 10.

${ }^{14}$ While the name "flea market" was almost certainly derived from Paris, older examples of "old things" markets exist, such as the Brussels' Marché Place du Jeu de Balle, founded in 1873, has roots in a similar market dating back to 1640 , strictly for old and used wares, held Tuesdays and Thursdays; even as early as the $16^{\text {th }}$ century, sources document an "Oude Merckt." See Paul F. State, Historical Dictionary of Brussels, (Lanham, MD: Scarecrow Press, Inc, 2004), p.192 and Anneli Rufus and Kristan Lawson, The Scavengers' Manifesto (New York: Penguin, 2009), p. 157. Current assessments of Marché aux Puces do not thoroughly consider the social, legal, and economic machinations that complicated the markets' growth. For brief histories, see Pamela Hough and Stuart Hough. Bit by the Fleas: An Insider's Guide to the Paris Flea Market. (Paris: Vilo, 2002); Sebak, “A Flea Market Documentary"; Pamela Klaffke, Spree: A Cultural History of Shopping, (Vancouver: Arsenal Pulp Press, 2003), pp. 112-114; and Maureen Stanton, Killer Stuff and Tons of Money: Seeking History and Hidden Gems in Flea-Market America, (New York: The Penguin Press, 2011), pp. 7-8.
} 
dead animals rendered into candles, bones turned into buttons, and hair fashioned into wigs. ${ }^{15}$

In the last quarter of the century, peddling became increasingly difficult within the Paris city limits. As in the United States, French officials began to systematize trash collection to prevent the spread of infectious diseases. The 1884 Paris ordinance requiring every building to include a standard, lidded garbage receptacle slowed scavenging substantially, and various ordinances limited the purveyance of used goods. ${ }^{16}$ In the early 1880s, chiffonniers, biffins, (rag-and-bone men), and les pêcheurs de lune (moon-fisherman) began to sell at a large scrap-metal market in the Parisian suburb of Saint-Ouen. Increasingly undesired within Paris's city limits, secondhand peddlers soon found this to be a convenient way to sell used goods. By 1885, enough secondhand merchants sold in Saint-Ouen for a newspaper to dub the congregation "marché aux puces," or "market with fleas,"-referencing the often-valid assumption that the secondhand cloth goods came with parasites. The French flea market grew rapidly and was renowned as a carnivalesque shopping experience by World War I, gaining cachet among American tourists. ${ }^{17}$

\footnotetext{
${ }^{15}$ Stanton, Killer Stuff and Tons of Money, pp. 7-8. See also Sandy Price, Exploring the Flea Markets of France (New York: Three Rivers Press, 1999); and Jerry Stokes, “A Flea Market By Any Other Name Is a Flea Market," in Rupert Thomas and Eglé Salvy, Antique \& Flea Market of London \& Paris (London: Thames \& Hudson, 1999).

${ }^{16}$ The municipal garbage cans, though different in shape and material, retain the name poubelle, after the Paris prefect M. Poubelle, who advocated for the ordinance. See David Bouchier, The Cats and the Water Bottles: and Other Mysteries of French Village Life (Mid Atlantic Production, 2002), pp. 37-38.

${ }^{17}$ A 1923 article boasted of "the prestige afforded by a flea market" in Paris. See "Real Flea Market Will Open in Paris," The Washington Post 26 Aug 1923, p. 33. In 1930, the Paris market was a place that "[n]early every tourist who visits France plans to make at least one visit," according to "The Flea Market," New York Times 22 Oct 1930, p. 23.
} 
Though not usually cited as a factor in the emergence of the Marché aux Puces, the advent of department stores was suspiciously concurrent with the marginalization of street peddlers. In 1867, a large, new building was constructed for Paris's premier fixedprice department store, Le Bon Marché. Considered by many to be the "first" department store in the world, Le Bon Marché changed the way French consumers shopped, codifying exchange interactions and in troducing new elements of fantasy and recreation. ${ }^{18}$ As grand magasins — large, highly organized department stores — grew up along Paris's main boulevards, laws regarding street selling multiplied, partly at the behest of department store owners' complaints, a pattern that would repeat in the United States. $^{19}$

While flea markets emerged partly in reaction to the institutionalization of consumer practices in the form of department stores, participants were also responding to the same factors enabling and necessitating those changes, such as an increased pool of discarded items and advances in transportation. In 1908, a completed metro line connecting Paris North to South secured Parisians' easy access to the market. As the Marché aux Puces expanded, the market's managers organized and structured the rows of goods, categorizing the types of items in order to facilitate shopping-much like department stores. ${ }^{20}$ In the Paris market's combining of mainstream and alternative

\footnotetext{
${ }^{18}$ Miller, The Bon Marché, pp. 2-11. For more on department stores and the effect of advertising and display on American consumers' desires around the turn of the century, see e.g. William Leach, Land of Desire: Merchants, Power, and the Rise of a New American Culture (New York: Vintage Books, 1993).

${ }^{19}$ Standards barring commercial participation were of course not new in France; previously, guilds had regulated entry to trades and governed craftsmanship and competition. This period represents a transition to different types of commercial limitations, not a departure from an entirely open system. These changes required adaptation on the part of participants at all levels of commerce. Miller, The Bon Marché, pp. 21-22.

${ }^{20}$ Hough, Bit By the Fleas, p. 18.
} 
consumer attributes, the Marché aux Puces portrays the intractability and adaptability of secondhand sales, and flea markets in general. And as the Marché aux Puces grew more attractive to consumers internationally, its success indicated and encouraged a growing enamorment with collectibles and antiques on the part of European and American travellers.

\section{Pushcart Wars: the Immobilization of Eastern City Peddlers}

The gradual emergence of what would become flea markets in the eastern U. S. cities was, like that of the Marché aux Puces, in part a response to politics and regulations, many of which reflected Americans' xenophobia. ${ }^{21}$ In cities like Chicago, Washington, D. C., and New York City, the large influx of immigrants, especially those from eastern Europe, many of whom were Jewish, determined the particularities of all types of informal trade, as seen in the previous chapter. Though no single model can signify accurately for all markets, the evolution of various markets on the Lower East Side of Manhattan and Maxwell Street Market in Chicago illustrated the political biases and grassroots backlash behind the establishment of new market-designated spaces that increasingly included secondhand goods.

Maxwell Street Market is one of many American flea markets that, before it was mostly moved and partially dismantled in 1994, claimed the title of the country's "first"

\footnotetext{
${ }^{21}$ Paris's immigrant population doubled between 1800 and 1840, compromising the city's economic structure and political stability. As Jerrold Seigal writes, "the image of the working classes merged with the specter of les classes dangereuses, the dangerous classes." See Seigal, Bohemian Paris: Culture, Politics, and the Boundaries of Bourgeois Life, 1830-1930 (New York: Penguin, 1986), pp. 22-23.
} 
flea market. ${ }^{22}$ At the time of Chicago's great fire in 1871, Eastern European immigrants were already creating Jewish enclaves in multiple parts of the city, and practicing the sorts of informal trade familiar overseas, including the collection and sale of used goods. ${ }^{23}$ The fire consumed numerous residences and businesses in and around the Loop, and another conflagration in 1874 ravaged the Near South Side where many poor eastern European Jews made homes. Burned-out businesses relocated, some in what was expected to be a temporary fashion, to Jefferson Street near Maxwell Street, just outside the fires' paths, as did displaced Chicagoans. ${ }^{24}$ The number of peddlers grew, spilling over onto Maxwell Street. By 1893, pushcart peddlers had become enough of a spectacle to warrant a special mention in the World's Fair guidebook as one of the city's most interesting sights. $^{25}$

While the World's Fair guidebook boasted of the unique display Maxwell Street provided, not all contemporary expositions were acclamatory. According to one reporter in 1896, Maxwell Street teemed with raucous commerce: "oratory, profanity, gesticulation, and fisticuffs are so often connected with the sharp bargainings of the street that the Maxwell Street Police Station exerts a not inconsiderable influence upon the

\footnotetext{
${ }^{22}$ Documentarian Phil Ranstrom outlines the battle to keep Maxwell Street Market in place in "Cheat You Fair": The Story of Maxwell Street, (Rantrom, documentary DVD), 2012.

${ }^{23}$ Adam Mendelsohn offers a concise overview of the importance of informal economies to Jewish life in Europe and the United States in Mendelsohn, "'It's the Economy, Shmendrick,", pp.14-17. For more on Europe's second-hand trade, see Madeleine Ginsburg, "Rags to Riches: the Second Hand Clothes Trade, 1700-1978," Costume: The Journal of the Costume Society 14 (London, 1980): 121-135; and Woloson, In Hock: Pawning in America from Independence Through the Great Depression (Chicago: The University of Chicago Press, 2009), pp. 16-17. On the economic history of Jews in modern Europe, see Derek Jonathan Penslar and Anthony W. Lee, Shylock's Children: Economics and Jewish Identity in Modern Europe, (Berkeley and Los Angeles: University of California Press, 2001), pp. 16, 20.

${ }^{24}$ Carolyn Eastwood, Near West Side Stories: Struggles for Community in Chicago's Maxwell Street Neighborhood, (Chicago: Lake Claremont Press, 2002), pp. 19-21.

${ }^{25}$ Eastwood, Near West Side Stories, p. 21.
} 
trade of that whole section." 26 This journalist reported with astonishment that despite the abject poverty of this area, there are no pawnshops. Why not? "Everything is too hopelessly second-hand. There's never anything new in the neighborhood except babies." To many native-born Americans, immigrants' seemingly irresponsible procreation signaled a willingness to live in the substandard conditions endemic to urban tenement housing in the United States. ${ }^{27}$ Racial references riddled the author's detailing of the unembarrassed haggling intrinsic to exchanges. The buyer must be unsentimental as "he seeks to buy for the least money which his small Shylock will accept."28

Poor oversight — the blight and benefit of informal economies — disadvantaged buyers from wholesalers down, and newspapers described the pushcart dealers as victims as well as swindlers. Scales and weights as well as appropriate baskets were altered or abandoned; legerdemain reigned as a rite of purchase. In addition to dealing with business interactions such as coal suppliers stacking pounds of firm coal atop inferior, soft stuff, large, empty gaps, and even rats, small dealers had to pay a yearly license tax-fifty dollars in $1896 .{ }^{29}$ Despite these hardships, activity swelled in the increasingly Jewish Near West Side (by 1910, 90 percent of the area's residents were Jewish). In

\footnotetext{
26“"Buy Much for a Penny: Commercial Side of One of Chicago's Oldest Neighborhoods," Chicago Daily Tribune 20 Sep 1896, p. 34.

${ }^{27}$ While many reformists attributed the unsanitary industrial-era housing condition to their inhabitants, others sought to encourage municipal responsibility, in part through comparison to other industrialized countries' housing provisions for workers. For example, Angela M. Blake recounts a tenement housing exhibition held on Fifth Avenue in New York City in 1900, whose purpose was to show the insufficiency of New York's and the United States' tenements in comparison to other countries. See Blake, How New York Became American, 1890-1924 (Baltimore, MD: The Johns Hopkins University Press, 2006), pp. 39-48.

${ }^{28}$ Shylock refers to the vengeful Jewish moneylender in Shakespeare's Merchant of Venice. See "Buy Much for a Penny," p. 34.

29 "Buy Much for a Penny," p. 34.
} 
1912, the city formally certified Maxwell Street as an open-air market—a step intended, hypothetically, to increase municipal oversight of the goings-on there. ${ }^{30}$

Far from all relevant legislation favored the merchants. In the first decade of the century, Near West Side peddlers vehemently resisted a series of Chicago-wide anti-noise laws restricting the "crying of goods" they deemed vital to their livelihood. The Nineteenth Ward alderman argued that the restrictions were weakly disguised discrimination against immigrant and working-class street vendors. The sellers rebelled, continuing to cry their goods, despite sporadic arrests and an eventual Supreme Court upholding of the statute. On July 26, 1911, peddler strikes and protests culminated in "a day of rioting and wild disorder such has not been seen in Chicago since the garment workers' strike." ${ }^{31}$ Multiple arrests and exorbitant fines dampened the rebellion for a while, while the designation of Maxwell Street as a formal market area helped to contain noisy peddlers who persisted in violating the ordinance. Finally, in 1913, the peddlers won a partial victory: the passing of a new ordinance allowing "the crying of wares by peddlers between 11 a.m. and 6 p.m." ${ }^{, 32}$ The new resolution did not end public legal disputes over market authority, though. Immediately after the market's formal designation, decades-long outrage erupted over the Maxwell Street Market master's unfair fee system. The conflicts resulted in fistfights and public law suits. ${ }^{33}$

\footnotetext{
${ }^{30}$ Eastwood, Near West Side Stories, p. 21.

${ }^{31}$ For more on the legislation of peddlers' noises in Chicago's near west side, see Derek Valliant, "Peddling Noise: Contesting the Civic Soundscape of Chicago, 1890-1913," Journal of the Illinois State Historical Society (vol. 96, No. 3, Autumn, 2003): 257-287.

${ }^{32}$ Amendment quoted in Chicago Record Herald July 2 1913, refer. in Carolyn Eastwood, Chicago's Jewish Street Peddlers (Chicago: Chicago Jewish Historical Society, 1991), p. 29.

${ }^{33}$ A long series of articles chronicled the ongoing struggles between the Maxwell Street venders and allegedly corrupt market masters. See for example, "Peddlers Accuse Market Master: Say A. J. Goldstein of Maxwell Street Collects Too Many Dime Fees," Chicago Daily Tribune 1 Jun 1913, p.3; "Riots Near at Market Hearing," Chicago Daily Tribune 12 June 1913, p. 5. Similar
} 


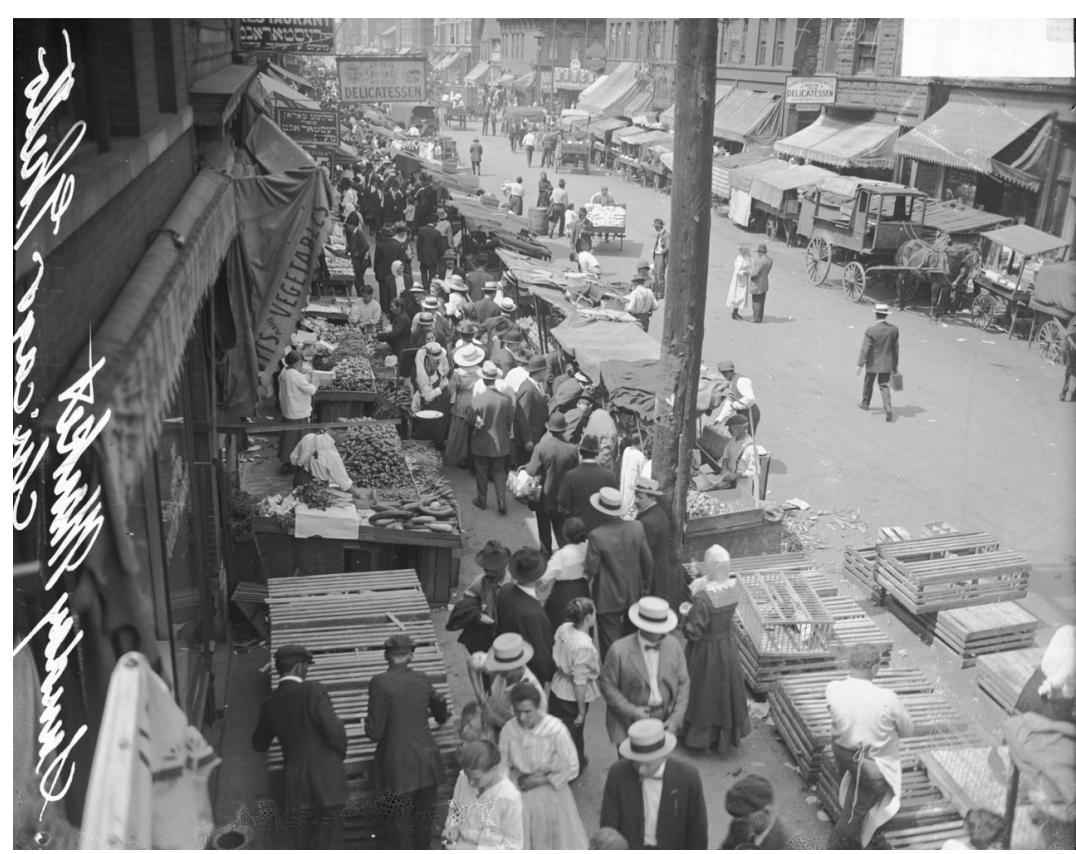

Fig 2.1. View from above, Maxwell Street Market, early in the morning, with many vendors just setting up. Chicago Daily News, 1917.

This pattern was not unique, though the scale of Maxwell Street's open-air commerce was unusual. In the wake of the declining popularity of public markets near the end of the nineteenth century, peripatetic pushcart peddlers presented new problems for many growing east coast cities. As city populations grew and especially, as trucks replaced farmers' wagons for transportation, public markets became more congested and bewildering to shoppers. Individual peddlers, selling any array of foods and other wares, acted as conduits from the central markets, distributing goods into neighborhoods and enclaves. The number of peddlers multiplied along with the number of immigrants, and lawmakers responded with high licensing fees_-fees much higher than for conventional merchants, especially when food was concerned-in addition to the other regulations limiting their domain. ${ }^{34}$ As early as 1894 , newspapers periodically reported the imminent

charges continued with future market masters. See "Fick Charges 'Big Money' Paid for Market Favors," Chicago Daily Tribune 15 July 1921, p. 15.

${ }^{34}$ As mentioned in chapter one, street peddling was a trade that Jewish immigrants historically favored. In New York City as early as 1855, before the major influx of Eastern European immigrants, the number of Jewish peddlers began to overtake that of Irish. An estimated minimum of four to five percent of all gainfully employed Jews in New York City were peddlers 
demise of pushcart peddlers, as retail merchants and lawmakers sought to staunch their rapid growth in what were dubbed "pushcart wars." 35 New York, Chicago, D. C., New Orleans, Omaha, and Milwaukee all took steps to reduce or eliminate pushcart peddlers, with varying results.

Middle-class reformers complained that peddlers swindled unsuspecting housewives, compromised sanitation and traffic safety, made disruptive noises, conducted illegal exchanges, and contributed to a system of bribes and extortion stemming from uneven regulation of licensing laws. Anti-Semitic language colored many of the positions taken. Both merchants and consumers described peddlers as "parasites." Undoubtedly, some peddlers skirted regulations and made bad deals, and frequently, this was attributed to their non-native origins. Chicagoan council members even considered restricting licenses to native-born peddlers. ${ }^{36}$

Despite reformers' aversions to urban chaos and native-born Americans' xenophobia, some consumers bemoaned the loss of some of the competitive advantages and conveniences peddlers offered when they were successfully banned. Even storebound, conventional merchants sometimes found peddlers' presence beneficial. In 1925, over 100 retailers and landlords in Brooklyn sought an order to compel pushcart vendors to sell in front of their shops. The businesses across the street, where merchants were

in the mid-nineteenth century. See Robert Ernst, Immigrant Life in New York City, 1825-1863 (Syracuse, New York: Syracuse University Press, 1994), p. 84.

35"War on the Cart Venders: An even Dozen Rounded Up and Fined in the Police Court," The Washington Post 14 Aug 1894, p.8.

${ }^{36}$ Proceedings of the City Council, (July 6, 1899), p. 987; Valliant, "Peddling Noise," p. 266; Deutsch, Building a Housewife's Paradise, pp. 30-31. 
permitted to park, were doing much better as the result of a general stimulation of trade. ${ }^{37}$ Temperate reformers admitted that the pushcarts were not an inherent nuisance and could even save consumers time and expense, but begged they no longer be allowed "to obstruct the streets and impede traffic, to scatter disease-breeding refuse, and to produce congestions that are dangerous in time of fire." 38 The growing popularity of the automobile boosted these complaints as the battle for the public thoroughfares cast the cart peddlers in the role of "traditional" — or outmoded, depending of the side of the argument.

Pushcart defenders cited benefits for consumers and the provision of oldfashioned charm to city ambiance. Also, pushcart businesses were recognized as special entrepreneurial activities for immigrants, especially in lieu of other employment opportunities. For many successful Maxwell Street merchants, selling second hand was a way to break into firsthand businesses, expand existing trade, or even stumble into untapped markets. At the turn of the century, Romanian immigrant Henry Mages supplemented his meager income as a tailor by peddling used pots and pans. Stuffed in one lot of wares, so the story goes, were a handful of baseball gloves. They sold so well that he began to truck exclusively in sporting goods, eventually opening a sporting goods store. By midcentury, Mages' son Morrie managed a small sporting goods empire, with a total of fourteen area stores. ${ }^{39}$ Similarly, Israel Lerner started out buying old shoes that people left in shoe stores when they purchased a new pair. Lerner gave them new soles

\footnotetext{
${ }^{37}$ For a specific study of these advantages as Chicago housewives perceived them, see Deutsch, Building a Housewife's Paradise, pp. 31-32; and "Merchants Sue for Push Cart Competition: Say Peddlers Parked at Door Boost Trade," New York Times 30 July 1925, p. 21.

${ }^{38}$ This comment appeared one year after the Triangle Shirtwaist Factory fire of 1911. See "The Romance of the Picturesque Pushcart," The New York Times 14 June 1912, p. SM9.

39 "Morrie Mages, 72, dies-'Mr. Sporting Goods,"' Chicago Sun-Times 26 Sept 1988; Shuli Eshel and Roger Schatz, Jewish Maxwell Street Stories (Chicago: Arcadia, 2004), pp. 49-52
} 
and a shine and sold them on Maxwell street — eventually he earned and learned enough to deal in new shoes. Lerner Shoes became one of the biggest footwear businesses in the Maxwell Street area. ${ }^{40}$

Also, those who still held "thrift" to be a good moral value saw virtue in choosing the cheaper, often secondhand, wares of pushcarts. In 1915, "Thrifty Rosa” glowed with pride over having supplied herself with a complete wedding trousseau from pushcarts for only $\$ 17.73$, including a "pair of fancy second-hand bronze slippers" for only twenty-five cents. $^{41}$ During the Great Depression both the imperative for thrift and the motivation on the part of primary retailers to staunch competition grew. Arguments on both sides waged throughout this first half of the century.

Much as in Chicago, New York City's pushcarts developed into a common informal market system in the last quarter of the nineteenth century. Stories of pushcart wars between vendors and city legislators detailed the dangers and costs that peddling presented to citizens one minute, and lamented the approaching disappearance of this "picturesque" aspect of city life in the next. ${ }^{42}$ In 1904, Manhattan's Commissioner of Street Cleaning assigned five city blocks to pushcart vendors for the city's 5,000 licensed food vendors in the hopes of isolating the "nuisance." The author clearly thought the peddlers ought to be grateful, opining that " $[\mathrm{b}] \mathrm{y}$ making himself a public nuisance the Manhattan push-cart peddler now gets from the city, absolutely free of charge, one of the

\footnotetext{
${ }^{40}$ The success was often hard-won; during the Great Depression, the Lerners, unable to sell stockpiled old shoes, resorted to burning them to shield against the winter cold. See Eshel and Schatz, Jewish Maxwell Street Stories, p. 63.

41 "Ghetto Beauty, Whose Trousseau Came From Pushcarts, Now Waits to Wed Same Day as Mrs. Galt," The Washington Post 14 Nov 1915, p. E14.

${ }^{42}$ See for example, "The Romance of the Picturesque Pushcart," The New York Times 14 June 1912, p. SM9.
} 
finest market stands in the world." 43 However, many peddlers protested the arrangement, preferring to remain peripatetic. Banding together, these working-class entrepreneurs fought against rising reformist notions of progress, modernity, and order. In 1906, the East Side Push Cart Peddlers’ Association wrote New York City Mayor McClellan, demanding to retain their "little privileges in order to make a living for ourselves and our families," or else they would march to City Hall and "show to this metropolis how its poor are treated." ${ }^{, 44}$

As the number of peddlers continued to grow, the mayor's new Pushcart Commission tried a new tactic, one that opposed the sanctioning of bounded markets for the peddlers. The commission could "see no reason why the City of New York should go into the business of providing shop space for dealers in any class of supplies, at a large annual loss, nor why taxpayers should be called upon to bear such a burden." Instead, the commission proposed a diffusion of pushcarts by limiting the number of peddlers allowed per block. After massive protest meetings and the threat of boycotts on the part of the United Citizens Peddlers' Association, the commission's suggested regulations were never pursued by the city. ${ }^{45}$

Instead of formal actions, selective prosecution and harassment of peddlers continued, which effectively concentrated pushcart activity, as officials in some areas were more tolerant than those in others. The Lower East Side was a popular trading spot by 1912 , as the debate over what to do about "the pushcart evil" continued. The estimated number of peddlers doubled, and a crooked "sort of padrone system" reportedly oppressed many of the now 14,000 itinerant workers. Bosses would stable carts in central

43 “Giving the Pushcart Men a Place of Business," New York Times 3 July 1904, p. SM3.

${ }^{44}$ Bluestone, "The Pushcart Evil," pp. 293-294.

${ }^{45}$ Bluestone, "The Pushcart Evil," p. 301. 
locations, charging for cart rental and sometimes insisting certain goods-also purchased there - be stocked in the cart, thus limiting the independence of peddlers. Reports of this arrangement usually focused on Greek communities. ${ }^{46}$

Journalists portrayed recommendations for designated pushcart market space alternatively as a win for the poor immigrant workers and as a sad victory for "utility over the picturesque." According to one author, "the series of markets for the use of small dealers" would rob "drab, somber tenement streets" of a rare source of vibrancy and attractiveness. ${ }^{47}$ Recognizing that dishonest peddlers increased public anomosity toward the Jewish population and fighting against extortionist politicians, some Jewish organizations led calls to reform pushcart licensing. The frequent solution was to erect permanent structures designed to contain and centralize the peddlers and to remove licensing from subjective control. Advocates argued that honest peddlers and merchants would benefit. Some peddlers agreed, at least in part. In New York thousands of peddlers organized the Push-Cart Peddler's Trust to protest existing licensing restrictions and to propose that permanent sites be built instead. ${ }^{48}$ As in Chicago, permanent market zones, when established, did not solve Manhattan merchants' problems. In 1922, Lower East Side peddlers mobilized to fight weekly fees for market stands, alleging extortion and corruption among the politicians and market owners, echoing the complaints of Maxwell Street venders. ${ }^{49}$

\footnotetext{
${ }^{46}$ In "Pushcart Question Reduced to Politics: Those Who Profit by Lack of Regulation Expected to Oppose Reform," New York Times 7 Jul 1912, p. 12.

47" The Romance of the Picturesque Pushcarts," p. SM9.

${ }^{48}$ See e.g., "Pushcart Peddlers Menace to Health," New York Times 6 Jul 1912, 16; "Pushcart Question Reduced to Politics," New York Times 7 Jul 1912, p. 12;

${ }^{49}$ See e.g., "The Push-Cart Peddlers," New York Times 4 Jun 1907, 6; "Peddlers Fight $\$ 1$ Fee," New York Times 27 Jun 1922, p. 18.
} 
Early twentieth-century market reformers included advocates of the City Beautiful Movement, a Progressive-era movement whose municipal results varied from city to city but often included public market renovations as part of a belief in urban planning's ability to mold the increasing number of new immigrants into Americans who shared moral and social priorities with the native-born population. ${ }^{50}$ An offshoot of progressive city planning's "ideal of comprehensiveness," the City Beautiful Movement's over-arching vision to beautify and sanitize urbanites' surroundings encountered resistance from critics of the plans' perceived elitism. ${ }^{51}$ As the first sentence of the first published book on city planning defined it, in the words of Frederick Law Olmsted, "City planning is the attempt to exert a well-considered environment on behalf of the people of a city over the development of their physical environment as a whole." ${ }^{, 52}$ The success of such programs, however, was not certain. Many of the public markets built to contain foreign-born peddlers as part of these programs suffered decline across the country in the 1920s. A precipitous rise in automobile ownership and the number of chain grocery stores thwarted aspect of city plans.

\footnotetext{
${ }^{50}$ For a case study on the evolution of one such market into a flea market, see Shepherd, When Culture Goes to Market. See also Katherine Tehranian. Modernity, Space, and Power: The American City in Discourse and Practice (Cresskill, NJ: Hampton Press, 1995), pp. 83-87; M. Christine Boyer. "Critics for sale: Merchandising History at South Street Seaport" in Michael Sorkin, Variations on a Theme Park: The New American City and the End of Public Space (New York: Hill and Wang, 1992), pp. 181-204.

${ }^{51}$ According to Jon A. Peterson, city planning differed from foregoing city organizing efforts mostly in the comprehensiveness of its pursuits. The term was coined in 1908. See Peterson, The Birth of City Planning in the United States, 1849-1917 (Baltimore, MD: The Johns Hopkins University Press, 2003), p. xvi; for more on the ideology and the criticism of the City Beautiful Movement, see William H. Wilson, The City Beautiful Movement (Baltimore and London: The Johns Hopkins University Press, 1989), pp. 75-95.

${ }^{52}$ Frederick Law Olmsted, Jr., "Introduction," John Nolen, ed., City Planning: A Series of Papers Presenting the Essential Elements of a City Plan, NML Series (New York: D. Appleton, 1916), pp. 1-2.
} 
The Eastern Market in Washington, D. C., for example, evolved as part of municipal goals of comprehensiveness. Originally a working nineteenth-century produce, meat, and fish market, the multi-site system of halls and open-walled structures built in 1873 (with 82 vending stalls) was intended to use zoning ordinances to impose order on what was viewed as the growing chaos of urban life. The market expanded in the first decade of the new century as part of the City Beautiful Movement, and the new structures were at least partially enclosed in attempts to isolate venders and keep them off the streets. The entire Eastern Market became more strictly regulated than before. Despite familiar accusations of corruption and unfair vendor treatment, the new system thrived until the 1920s, when nationwide, public markets were displaced by more "efficient" food systems such as chain stores. By 1929, portions of the Eastern Market system were completely shuttered. ${ }^{53}$

Public markets nationwide, pushcart-filled or stall-oriented, declined precipitously during the Great Depression, as chain grocery stores consolidated control of urban food distribution. Though peddlers had always offered an array of goods besides food, the demand for secondhand items grew in the 1930s. In New York City, secondhand clothing and goods began to crowd the open stalls of the street markets as far north as $137^{\text {th }}$ Street. $^{54}$ Throughout the 1930 s, coinciding with the apparent proliferation of street-level

\footnotetext{
${ }^{53}$ For a description of municipally constructed nineteenth-century U. S. public markets and their role in the public sphere, see Helen Tangires, Public Markets and Civic Culture in NineteenthCentury America (Baltimore: Johns Hopkins University Press, 2003). For a broader examination of public markets, including their relationship with the City Beautiful Movement, see Tangires, Public Markets (New York: W \& W Norton and Company, Inc, 2008); and Shepherd, When Culture Goes to Market, pp. 25-32. Tracey Deutsch details the changes in food distribution in Building a Housewife's Paradise. See also Marc Levinson, The Great A \& P and the Struggle for Small Businesses in America (New York Farrar, Straus, and Giroux, 2011).

${ }^{54}$ The increase in secondhand goods, especially clothing, is based on author's survey of almost a thousand photographs of New York City street scenes. For example, "Municipal Archives
} 
secondhand sales, New York City's open-air system began to disappear, replaced and consolidated by a few enclosed markets — though street markets like the one in Figure 2.2 were never fully eradicated.

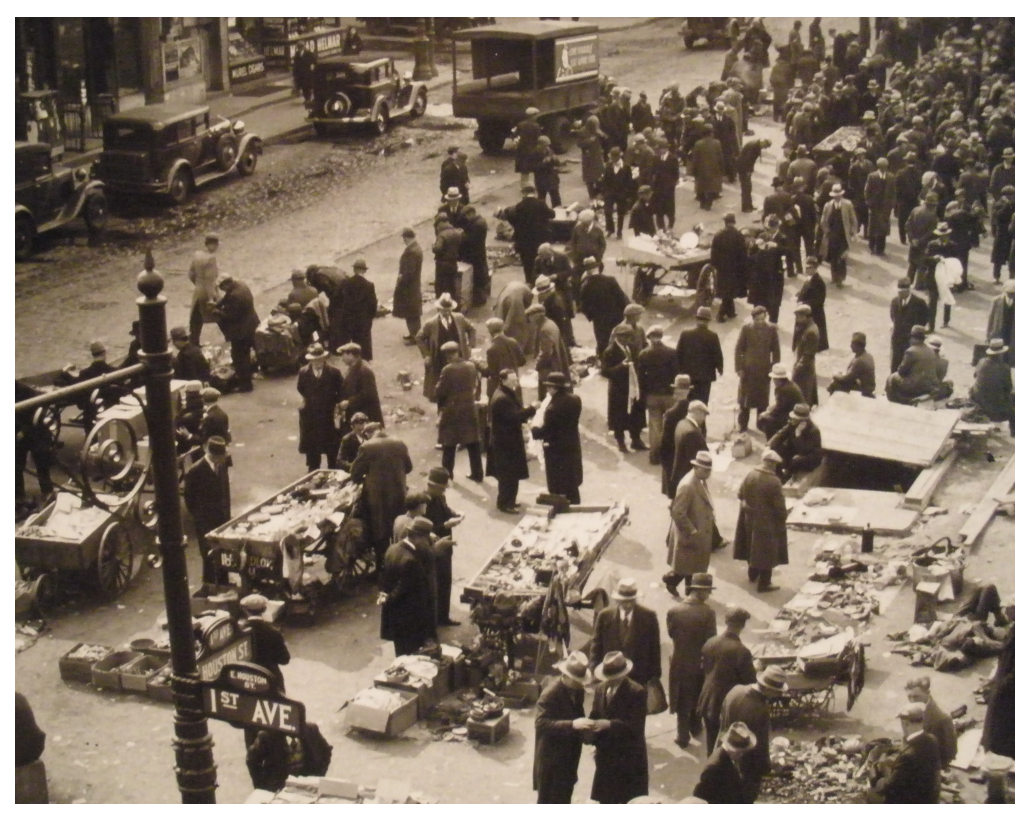

Fig. 2.2. Lower $1^{\text {st }}$ Ave. Street Market, circa 1935. Courtesy of the Joyce F. Menschel Photography Library, Metropolitan Museum of Art.

By the time it was New York City's turn to host the World's Fair in 1939, no guidebook was published extolling the picturesque virtues of the pushcarts. Instead, Mayor LaGuardia and his market commissioner eulogized the institution in an exhibit section titled, "The Life and Death of the Pushcart." ${ }^{, 55}$ LaGuardia fought long and hard to delimit the area of pushcart sales, insisting entrepreneurs focus their interests on stores situated on private property, as befit the image of a truly modern city. In the end, it was not arguments of sanitation, privation, danger, noise, or swindling that went the farthest in tolling the itinerant pushcarts' death knell, but the curse of antiquation. The 1930s saw

Collection" (Boxes 1398-1957 New York City Municipal Archives [NYCMA]); "Department of Public Works" (Public Markets, Boxes 01156 and 21462, NYCMA); and Joyce F. Menschel Photography Library at the Metropolitan Museum of Art.

55 "Department of Markets" (LaGuardia Papers, Box 3638 NYCMA), qtd in Bluestone, "The Pushcart Evil," p. 307. 
more successful legislation restricting the mobility and territory of the old-fashioned peddlers than previous decades. ${ }^{56}$

By WWII, enclosed market structures and prohibitive restrictions, coupled with decreased immigration, had severely limited - though not abolished — peripatetic sales across the country. What remained began to resemble flea markets, some with systems of rented stalls and heavy weekend traffic. The demographics of those remaining or transformed into market stall renters changed with the times as well. By the 1930s, many of the Jewish families who had populated Maxwell Street had dispersed to other neighborhoods. African-Americans relocating North in the Great Migration of the 1920s became the predominant demographic at Maxwell Street Market, which became known as a center for Chicago blues music, while continuing to be a colorful market of various goods. ${ }^{57}$ Itinerant blues and minstrel musician Daddy Stovepipe began playing at Maxwell Street in the 1920s, after almost two decades of performing in southern minstrel acts. Stovepipe continued to perform on Maxwell Street into his nineties, even after several recording deals. Throughout the changes at Maxwell Street Market, as Figure 2.3 shows, secondhand goods remained a central, even increasingly important, part of the market. $^{58}$

\footnotetext{
${ }^{56}$ Bluestone, "The Pushcart Evil," pp. 308-309.

${ }^{57}$ For more on the transformation of Maxwell Street Market, see Ira Berkow, Survival in a Bazaar (New York: Doubleday \& Company, Inc. 1977); and Mike Shea, And This is Free, and Shuli Eshel, Maxwell Street: A Living Memory (Kartemquin Films, 2008).

${ }^{58}$ Lori Grove and Laura Kamedulski offer images and brief accounts of the blues influence on Maxwell Street after the 1920s, including Daddy Stovepipe, in Chicago's Maxwell Street (Chicago: Arcadia Publishing, 2002), p. 81. Brief histories of Daddy Stovepipe, born Johnny Watson, appear in several blues histories, such as Robert Springer, ed., Nobody Knows Where the Blues Come From: Lyrics and History (Jackson, Mississippi: The University of Mississippi Press, 2006), pp. 41-42.
} 


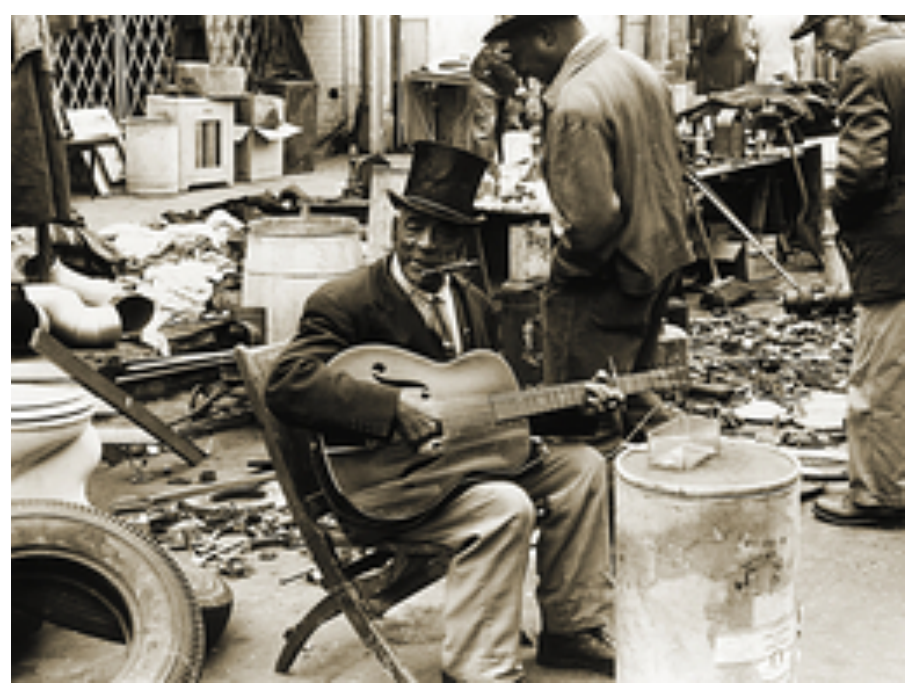

Fig. 2.3. Daddy Stovepipe playing on Maxwell Street in 1959, surrounded by secondhand wares, wearing his trademark nineteenth-century stovepipe hat. Photograph by Clarence Hines. Chicago History Museum.

\section{Hoss Mondays: County Seat Trade Days and the Rise of Antiques and Collectibles}

Like their urban counterparts, many rural flea markets evolved in close relationship to food sales, springing from agricultural trade fairs and farmers markets. As they did in urban public markets, secondhand goods sustained established farmers markets during decades of decline - until the local foods movement in the late twentiethcentury brought about a resurgence in their popularity. ${ }^{59}$ In the nineteenth century, rural produce sellers often coordinated their efforts with county court days. First Monday Trade Days in Canton, Texas - another self-proclaimed contender for the "first" U. S. flea market—-began as a trading market decades before the term flea market was applied. ${ }^{60}$ In the 1850 s, the circuit judge came to Canton, the county seat, to hold court and conduct legal business the first Monday of every month, a practice common in rural

\footnotetext{
${ }^{59}$ While many recent books advocate buying local and recount the environmental, civic, and personal benefits of the local foods movement (or, of being a "locavore"), few historical accounts of its rise exist. Britta Ann-Christin Solan offers a case study of the local foods movement in Iowa City in The Culture of Local Food: A Life History Study of Farmers' Market Customers in a Midwest City (Iowa City: University of Iowa Press, 2002).

${ }^{60}$ In 2006, Barron told the author that the NFMA officially recognized First Mondays as the oldest flea market in the U. S.
} 
areas at this time, particularly in the American South. These "Court Days" commonly did double duty as market and town meeting days. ${ }^{61}$ In Texas, the figure of the courthouse presided over towns' public squares, establishing a habit of overlap between political and social functions. ${ }^{62}$ Town squares were the site of political speeches and the headquarters for travelers' amusements and accommodations. They often housed the public well or sistern and hosted auctions. Nineteenth-century observers commented on the economic significance of the squares in many Texas towns. ${ }^{63}$

Canton's first Mondays became the day for townspeople to trade livestock, and sell and buy produce and other goods in the town square - and perhaps stop to watch a murder trial or hanging. ${ }^{64}$ First Mondays seemed to some designed to guarantee fine attendance, since Van Zandt County had a long-standing reputation for notorious criminals. In one oft-recounted tale, a group of outlaws lured James Hogg, the first native Texas governor, over county lines and shot him in the back (he recovered and went on to bear four children, one of whom, the auspiciously named Ima Hogg, would be quite the connoisseur of secondhand goods, at the vanguard of modern American collecting in the 1920s). ${ }^{65}$

\footnotetext{
${ }^{61}$ Allan Kulikoff, "Households and Markets: Toward a New Synthesis of American Agrarian History." The William and Mary Quarterly, 3d Ser., 1.1 (April, 1993): 342-355. For a brief history of First Mondays, see David Nelson Wren, Every First Monday: A History of Canton, Texas (Wichita Falls, Texas: Nortex Offset Publications, 1973).

${ }^{62}$ Willard B. Robinson, "The Public Square as a Determinant of Courthouse Form in Texas," The Southwestern Historical Quarterly, 75.3 (January 1972): 339-372.

${ }^{63}$ See for example, Fort Worth's Daily Gazette 16 Jan 1879, in which it was remarked that any obstruction to the square would be protested by a myriad of business interests; qtd in Robinson, "The Public Square as a Determinant of Courthouse Form in Texas," pp. 342-343.

${ }^{64}$ Despite the fact that histories of First Monday love to recount the popularity of hangings, there were only two formally recorded in Van Zandt County. See David Nelson Wren, Every First Monday, p. 8.

${ }^{65}$ Canton also was home to the first woman to be sentenced to life in prison in Texas and to a very active homegrown version of the Klu Klux Klan. See Wren, Every First Monday, pp. 8-9.
} 
By 1930 Canton's trade days attracted sojourners from surrounding states, often looking to swap or buy mules, horses, hunting dogs, and wagons. Secondhand farm implements, household goods, and clothing were added to the mix as the market covered more and more of the square. Known to many by then as "hoss Mondays," the event attracted big enough crowds to provide buyers for almost anything. Swaps were often sweetened (and tight wallets loosened) with locally made corn whiskey or home brew. While women were newly permitted to attend, their presence was still dissuaded, and the trade days maintained a rough and ready reputation. One story from the 1930s illustrated just how much was considered fair game for swapping. A Texas oil worker recalled that two mule-traders drove into town with their families - apparently the "women were slatternly, and the kids were as wild as coyotes" - and left having traded out their companions, children and all. ${ }^{66}$ One slightly different version had the couples legally married; accordingly, they went to the District Clerk to try for a validated swap. ${ }^{67}$

In other county seats in the South, flea markets emerged from similar circumstances. In Maysville, Kentucky, and Emporia, Virginia, Court Days — and de facto market days - fell on Wednesdays. The Monday Market in Webster, Florida, also began as a farmer's market but soon included secondhand goods. In 1937, a group of central Florida farmers dissatisfied with their distribution options formed a co-op. Scraping together their own assets and materials (including cypress harvested from nearby swamps), they built a market in the center of Webster from which to auction their

\footnotetext{
${ }^{66}$ Gerald Lynch, Roughnecks, Drillers, and Tool Pushers, (Austin: University of Texas Press, 1987), p. 53.

${ }^{67}$ Wren, Every First Monday, p. 28.
} 
produce. ${ }^{68}$ Since a local blue law prohibited the sale of any goods on Sundays, market day was Monday. ${ }^{69}$ The market adapted to changes in local farming trends, with merchants replacing the vegetable auction with a cattle auction when changing weather patterns compromised produce production. Empty stalls soon housed secondhand clothing and goods, which were sold directly instead of auctioned. By midcentury, Monday was devoted to Webster's flea market, and Tuesday was reserved for a cattle auction. $^{70}$

After the 1929 stock market crash, many such agricultural sales in small towns, county seats, and rural outposts included commercially produced castoff goods to offset a decline in available produce. While The Great Depression stalled the expansion of thrift stores, the acquisition of collectibles or antiques, which had been of growing interest among the upper-middle and upper classes for decades, continued to be popular. In fact, in the wake of the stock market crash, many were attracted to forms of investment that might survive financial market collapses. The belief that well-chosen objects responsibly maintained would only increase in value gained traction during the first of the century. ${ }^{71}$ Farming families' outdated furnishings, moldering in attics, had increasing appeal and value at the same time family farms were dying.

${ }^{68}$ Webster's Westside Market claims to be Florida's largest and oldest flea market. See Bruce Hunt, "Webster," in Visiting Small-Town Florida, $3^{\text {rd }}$ ed. (Sarasota, Florida: Pineapple Press, Inc., 2011), pp. 131-135; Terry Goodson (Webster Westside Market vender), interview with the author, September 9, 2005; also see websterwestside.com.

${ }^{69}$ Blue laws, or Sunday-closing laws, remained part of U.S. policy for several hundred years, until after WWII in many places. David N. Laband and Deborah Hendry Heinbuch describe what sustained and eventually reversed these sales prohibitions. See Laband and Heinbuch, Blue Laws: The History, Economic, and Poltics of Sunday-Closing Laws (Lexington Books, 1987).

${ }^{70}$ Goodson; Hunt, "Webster," pp.132-133.

${ }^{71}$ Book collector William Dana Orcutt noted the increase in rare book prices "even during periods when the country is suffering from industrial depression and Wall Street prices are steadily declining." See William Dana Orcutt, The Magic of the Book: The Story of Collecting (London: Herbert Jenkins, 1924), p. 13, qtd in Steven M. Gelber, Hobbies: Leisure and the Culture of Work in America (New York: Columbia University Press, 1999), p. 109. 
Before the end of the nineteenth century, few people collected older Americanmade goods - the privileged elites who bought antiques focused on European-made items. The increased production and access to new goods spurred a heightened interest in old objects of all origins in the late 1800 s, fueled by nostalgia for an imagined "simpler" time in the face of rapid social change. Victorian idealization of hearth and home, often called "the cult of domesticity," went hand in hand with a new admiration for colonial American household items. Many of these revered clocks and housewares made their commercial debuts as collectibles in the fundraising fairs popular among turn-of-thecentury Americans, which introduced the hobby of collecting to some members of the

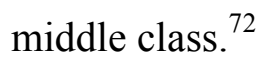

At the beginning of the century, an "aesthetic revolution" in antiques changed the nature of collecting. Some goods were newly valued for their utility as well as a fashionably handmade look. ${ }^{73}$ Around the same time that the Salvation Army and Goodwill were renaming "junk shops" "thrift stores," the appellation "antique store" began to replace that of "curio shop" or "Old Curiosity Shop.."74 As Bettina Belmont's 1937 flea market endeavor demonstrates, casual collectors often specialized. Interest in Americana of various sorts — including hunting gear — demonstrated a rise in aesthetic

\footnotetext{
${ }^{72}$ Elizabeth Stillinger, The Antiquers: The lives and careers, the deals, the finds, the collections of the men and women who were responsible for changing taste in American antiques, 1850-1930 (New York: Alfred A. Knopf, 1980), pp. xi-xii. For more on fundraising fairs, see Gordon, Bazaars and Fair Ladies. For more on the development of collecting as a hobby, see Gelber, Hobbies, esp. pp. 60-152.

${ }^{73}$ The arts and crafts movement in America de-emphasized the smoothness of mass production in favor of more "primitive" and "natural" style. For the implications of this for American thought and culture, see T. J. Jackson Lears, No Place of Grace: Antimodernism and the Tranformation of American Culture, 1880-1920 (New York: Pantheon Books, 1981).

${ }^{74}$ See Peter F. Buckley, "The Old Curiosity Shop and the New Antique Store: A Note on the Vanishing Curio in New York City," Common-place 4.2 (January 2004), accessed May 17, 2013, http://www.common-place.org/vol-04/no-02/buckley/; and Briann Greenfield, Out of the Attic: Inventing Antiques in Twentieth-Century New England (Amherst and Boston: University of Massachusetts Press, 2009), p. 9.
} 
patriotism after the end of World War I. A spate of museum exhibits displaying American decorative arts, beginning with the Metropolitan Museum's 1909 HudsonFulton Celebration and culminating in the establishment of the Metropolitan's acclaimed American Wing in 1924, verified the artistic merit of these goods. ${ }^{75}$

By the nationalistic 1920s, avid collectors like Henry Ford led a shift in taste, moving away from European antiques and toward rustic, American-made collectibles. "Colonial corners" or whole rooms decked out in antiquated native goods underscored the popularity of this fad. Though the New England farmhouse was most frequently the presumed target of professional dealers looking for Americana, either for individual collectors or for sale at auctions, collectors did not all live in Pennsylvania. In fact, Ima Hogg, the daughter of the Texas governor shot in Canton, Texas, was "an important part of the collecting scene in the 1920s" and lived in relative proximity to the famous First Mondays. ${ }^{76}$ While Hogg joined Henry du Pont and Henry Ford in bidding wars at important New York auctions of the era, she also cultivated relationships with more than twenty dealers, who were personally acquainted with her tastes, as was common practice for a growing class of very wealthy collectors. Such dealers focused on the generous stores in New England farmhouses at first, but the antique market did not remain geographically constrained for long. ${ }^{.7}$

\footnotetext{
${ }^{75}$ For more on the museum exhibits at the beginning of the century, see Elizabeth Stillinger, The Antiquers, xiii-xv; and Greenfield, Out of the Attic, pp. 2-3

${ }^{76}$ Stillinger, The Antiquers, p. 252; see also Kate Sayen Kirkland, The Hogg Family and Houston, (Houston: University of Texas Press, 2009), p. 244

${ }^{77}$ Greenfield, Out of the Attic, p. 13.
} 
Early twentieth-century dealers swept the countryside for attractive Americana at the same time small-scale farmers' fortunes were declining. ${ }^{78}$ Small-time dealers or "pickers," as they were known in the trade, roamed the countryside searching for saleable collectibles. Because of their door-to-door methods, such bottom-rung traders were also called "knockers" or "rappers."79 While pickers relied on the naiveté of country farmers - as well as their increasing poverty - country dwellers soon became aware of the monetary value of their attic wares. As early as 1910, knowledgeable antique dealers suggested that even in the countryside "people who have antiques to sell nowadays have a pretty clear idea of their value." $\$ 0$

New England assuredly held the distinction of the first developed antique market in the United States, but before long, Southern regions had their own burgeoning antique shops. Museums in the Midwest and West cultivated their own Americana displays in the 1920s, indicating the extension of those goods' popularity and knowledge of their value nationwide. ${ }^{81}$ Dealers often expanded more modest secondhand businesses into antique markets, increasing their profits along with their knowledge of antiquities. Some mixed less expensive everyday items and mid-range collectibles with high-end antiques, tempting the less wealthy patrons who fantasized about the expensive pieces to buy something in their price range. ${ }^{82}$

\footnotetext{
${ }^{78}$ For more on the decline of family farms in the Midwest and South, see for example, Mary Neth, Preserving the Family Farm: Women, Community, and the Foundations of Agribusiness in the Midwest, 1900-1940 (Baltimore MD: Johns Hopkins University Press, 1998); and Jack Temple Kirby, Rural Worlds Lost: The American South, 1920-1960 (Louisiana State University Press, 1987).

${ }^{79}$ Greenfield, Out of the Attic, pp. 77-79.

${ }^{80}$ Walter Dyer, The Lure of the Antique (New York: Century, 1910), 13; qtd in Greenfield, Out of the Attic, p. 79.

${ }^{81}$ Greenfield, Out of the Attic, p. 53.

${ }^{82}$ Greenfield, Out of the Attic, pp. 57-89.
} 
For those who could only daydream about traveling—-through Europe or the U.S. countryside - to collect rare or desirable objects, avid sampler collector Mabel Urner Harper's syndicated column, "The Married Life of Helen and Warren," offered a glimpse into that world. Began in 1915, "Helen and Warren" ran for thirty years, and regaled a broad reading audience with the adventures of an antique-collecting couple. The rise of the automobile once more played a role in the establishment of flea markets, in this case by facilitating travel outside urban areas. Motoring vacations among the middle and upper-middle classes living in cities privileged outdoor retreats as healthful excursions. ${ }^{83}$ Fictional New York City couple Helen and Warren were no exception; by 1916, an "Auto Tour" led them to a farmhouse stay. ${ }^{84}$ Several times in the 1920s, a "Sunday Motor Trip" resulted in the purchase of some choice object, like an old table with a "real pie-crust edge. ${ }^{.85}$

Harper's sojourn stories took readers overseas as well. As antiques and collectibles became elite hobbies of preference, various international flea markets joined Marché aux Puces as hyped tourist destinations—about which "Helen and Warren" educated their readers. The appeal to travellers during the Great Depression included flea markets' cost-cutting value as well as their festive airs. A 1931 Chicago Daily Tribune article recommended that "every right minded American in Rome" visit the "rag market"

\footnotetext{
${ }^{83}$ For more on the rise of outdoor and "cross-class" vacationing in the 1910s and 1920s, see Cindy Aron, Working At Play: A History of Vacations in the United States (Oxford and New York: Oxford University Press, 1999).

${ }^{84}$ Mabel Herbert Urner, "Their Married Life: Helen and Warren Go On an Auto Tour and Spend the Night at a Farmhouse," The Washington Post 24 Jul 1916, p. 5. Helen Sheumaker writes about Mabel Urner Harper's fans and their investment in Harper's married-life collecting narratives. From Sheumaker, "'I Hope You Won't Mind My Writing You': Mabel Urner Harper and her antique-collecting fans," unpublished paper presented at the American Historical Association annual conference, January 2013.

${ }^{85}$ Mabel Herbert Urner, "Their Married Life: A Remote Farmhouse Offers Dubious Shelter on a Stormy Night," The Washington Post 26 Aug 1928, p SM5.
} 
in the campo dei Fiori, for the atmosphere as well as for the deals. ${ }^{86}$ In the 1930 s, Harper's column emphasized the importance of value as well. At a market in Milan, Helen mused over potential purchases, assessing objects for appropriate travelling size and weight and "good value — that almost an obsession." ${ }^{87}$ The heightened esteem of collectibles and concern with affordability coincided with the fashionability of European flea markets. Soon, even enclosed secondhand venues in the U.S. that might have called themselves antique shops began to adopt the moniker flea market instead. ${ }^{88}$

The Great Depression disrupted many economic trends, but secondhand commerce adapted. So, too, during World War II, when demand for secondhand soared while supply flagged. "Junk men" still turned a tidy profit collecting scraps for industry and paper for the war effort. ${ }^{89}$ Wood pulp and rag recycling for the production of paper helped sustain independent gleaners as well as Goodwill and the Salvation Army through the 1930 s and into the 1940 s, when quality discarded goods were scarce. ${ }^{90}$ Immediately after the war's end, the cost of secondhand clothing increased in the Bowery, where active trade persisted despite Mayor LaGuardia's success in quashing pushcart business (the clothes were displayed on sidewalks or arranged on racks outside of firsthand businesses, instead of carried on pushcarts). In 1945, clothing demand outstripped supply

\footnotetext{
${ }^{86}$ Eve Cousin, "Planning for Autumn Activities in Society," Chicago Daily Tribune 16 Aug 1931, p. D1.

${ }^{87}$ Mabel Herbert Urner, “The Married Life of Helen and Warren," Los Angeles Times 28 March 1937, p. 118.

${ }^{88}$ Flea markets could be anything from Maxwell Street in Chicago to "a new and swanky interior decorator's shop out Sunset which advertises itself as specializing in 'glass bathrooms and lovers' boudoirs." See Rosalind Shaffer, "Bodyguard Is Accepted Rule in Hollywood," Chicago Daily Tribune 17 Jul 1932, p. F5; See for another example of a shop calling itself a flea market, see Ed Sullivan, "Broadway: 42 ${ }^{\text {nd }}$ Street," The Washington Post, 16 Jul 1936,p. 18.

${ }^{89}$ See for example, Freeman Cleaves, "The Junk Man: Collecting Scrap for Industry Has Become a \$2 Billion Business," Wall Street Journal 17 Mar 1944, p. 1.

${ }^{90}$ Grimm, "Working with Handicaps," 54-58; Strasser, Waste and Want, pp. 226, 240.
} 
not only because of wartime restrictions, but because of liberation efforts--the United National Clothing Collection's drive to send American discards to newly liberated Europe emptied the closets of Americans anticipating newly available goods. Oldclothiers hiked prices fourfold in the "frowsy streets"-which were inevitably compared to Paris's flea market. ${ }^{91}$ The price of used goods rose with demand, and not just for the Bowery's native shoppers, who were plentiful. An international trade in secondhand clothing relied on this de facto flea market, with "the coats, dresses, suits, shoes, dilapidated felt and straw hats that are delivered to Elizabeth Street in carload lots from small dealers throughout the country. . .shipped promptly to remote parts of Africa, the Near East, Europe, and India." ${ }^{92}$ In 1945, though, global traders buying in bulk were competing with that year's biggest buying customer, the U.S. government. The Bowery's estimated $\$ 3,000,000$-a-year business earned the bulk of its profit from the Procurement Division of the Treasury Department. In May 1945, the Army was the Bowery wholesale merchants' biggest buyer, with twelve and a half million pounds of clothes on order, all headed for liberated areas, reportedly ahead of the United Nations Relief and Rehabilitations Administration. ${ }^{93}$

By 1950, the sale of all consumer goods in the U.S. was on the rise, and used items were no exception. Various clubs, especially women's groups, staged a slew of "Parisian" markets across the country, serving as benefit sales for aid to rebuild France in

\footnotetext{
${ }^{91}$ See "Old-Clothes Market," New York Times 6 May 1945, p. SM17.

92 "Old-Clothes Market," p. SM17. This international bulk clothing trade was in its infancy in the 1940s but would grow to be a central profit-making component for thrift stores as well, by the end of the twentieth century. For more on later developments, see Karen Transberg Hansen, Salaula: The World of Secondhand Clothing and Zambia (Chicago and London: The University of Chicago Press, 2000); and Elizabeth L. Cline, Overdressed: The Shockingly High Cost of Cheap Fashion (New York: Penguin, 2012), pp. 122-130.

93 "Old-Clothes Market," New York Times, p. SM17
} 
the wake of German occupation. ${ }^{94}$ Stores, markets, and benefit sales relying on used goods all called themselves flea markets, appealing to the name's exotic affiliation. Eastern bazaars and the Marché aux Puces were the comparisons most often given in media portrayals of the growing shopping genre. And as one New York Times article about Mexico's markets claimed in its headline, “The Most Colorful Part of Every Town Is Where the Junk Is Sold." ${ }^{95}$ In 1952, the Chicago Tribune listed Madrid's “'rastro,' or flea market" chief among the "shopping bargains Spain's capital has to offer." ${ }^{96}$ For postwar patrons geared up to buy and to be entertained, flea markets held a new appeal, especially among a growing class of self-defined rebels. Secondhand markets offered opportunities to participate in the great collective rush to buy without appearing to be conformist.

\section{The Rose Bowl and Drive-In Theaters: Flea markets as a "phenomenon of the sixties"}

Beginning in the 1950s, creative entrepreneurs eyeing the popularity of antiques started flea markets from scratch—like Russell Carrell, generously dubbed the "granddaddy of U. S. flea markets." Carrell held his first "one-day rural flea market" in Salisbury, Connecticut, in 1958. Carrell called the event "antiques in a cow pasture," and swore that when he began, some who paid the fifty-cent admission fee expected to see a

\footnotetext{
${ }^{94}$ See for example, Judith Cass, "Benefit Sales Offer Widely Varied Items," Chicago Daily Tribune 15 Apr 1947; "Aids in Two Charity Benefits of the Near Future," Chicago Daily Tribune 5 May 1947, p. 25.

${ }^{95}$ Robert Spiers Benjamin, “Mexico's Markets: The Most Colorful Part of Every Town Is Where the Junk Is Sold," New York Times 10 Dec 1950, p. XX19.

${ }^{96}$ Jocelyn Bush, "The Tribune Travelers' Guide: Spain Looks to 80,000 U.S. Tourists in '52," Chicago Tribune 6 Apr 1952, p. G24.
} 
flea circus. ${ }^{97}$ That same year, drive-in theaters reached their peak, and then quickly plummeted in popularity, losing out to the new television culture stealing suburban clientele and the coinciding switch to daylight savings time in many states, which in many cases eliminated a showing by decreasing the time when the sky was dark enough for the screen to be seen. ${ }^{98}$ Flea markets emerged as natural replacements for drive-in theaters, as well as filling empty cattle lots. Flea markets were convenient solutions for landowners looking to use large, open lots without the expense of converting them into shopping malls. Some drive-in theater owners entirely abandoned the theaters, simply shifting to the business of flea market management. Other flea markets served as models of improvisational integrated economies, in which space is used for one business to defray the costs accrued by another. At a time when drive-in theaters had passed their peak in popularity and had begun quickly closing across the country, this integration of daytime flea markets allowed some theaters to retain their original use after sunset. ${ }^{99}$

${ }^{97}$ See Marilyn Hoffman, "Flea Market: Big Business in U. S.," Christian Science Monitor 10 Sep 1976, p. 2.

${ }^{98}$ Drive-in theaters peaked in 1958 and began to decline dramatically over the next two decades. For more details about the fight against daylight savings time on the part of theater owners, see Kerry Segrave, Drive-in Theaters: A History from Their Inception in 1933 (North Carolina: McFarland and Company, Inc. Publishers, 1992), pp. 126-130; Paul Lukas, "The Last Picture Shows," Money 30. 8 (August 2001): pp. 90-96. For example, in the 1970s, three drive-in theaters in Florida began using their lots for flea market space during the day: Delray Lost Drive-In Swap Shop (1970), Naples Drive-In Theatre Flea Market (1974), and Ocala Drive-In Swap Shop (1979). ${ }^{98}$

${ }^{99}$ NFMA director Gail Barron confirmed the relationship between the rise in flea markets and the decline of drive-ins. According to Barron, many theater owners simply converted the same undeveloped property they had been using for viewing space into a flea market. As Barron pointed out, these were business people, eager to change the use of their land to something profitable with minimal expense. Barron, interview with the author, October, 2006. Most early California swap meets seemed to be integrated with drive-in theaters. See for example, Jack Schermerhorn, "Drive-in Traders Buy, Sell, Swap Everything from Bullets to Bikes," Los Angeles Times 30 May 1965, p. CS10; Bart, "The Price of Parakeet? A Rolling Pin," New York Times 8 Nov 1965, p. 37. 
By the 1960s, many U. S. flea markets (or swap meets, as Californians often called them) had uniform markers: large, outdoor events with anywhere between 20 to 1,000 different vendors, mostly selling used goods. Farmers markets—which also began to re-establish themselves slowly in the 1970s — specified the addition of flea markets and mapped separate rows for produce, antiques, and other items. California rapidly became the nation's "swap meet" headquarters, followed in flea market popularity by Texas and Florida. The rise in California markets correlated with the decline in drive-in theaters, which had enjoyed more success in that state than in any other. ${ }^{100}$ The New York Times estimated in 1965 that in Southern California there were at least twenty weekly swap meets, events "which embrace ingredients of an oriental bazaar and the Paris Flea Market." $" 101$

Exotic elements at postwar flea markets were not contrivances. At the turn of the twentieth century, assimilation programs such as the City Beautiful Movement established new markets in attempts to organize cities and to educate newcomers as to the expectations of the established community. Decades later, the tables turned. Flea markets - especially those in California—introduced native-born Americans to the cultural practices and trade items familiar to new immigrants. On the West Coast, Latin American and Pacific Rim immigrants continued social and economic interactions transported from countries where open-air markets were commonplace, somewhat mimicking how East Coast informal economies conformed to imported practices from Eastern European countries earlier in the century. By the late twentieth century, flea-

\footnotetext{
${ }^{100}$ Segrave, Drive-in Theaters, p. 196.

${ }^{101}$ Bart, "Price of Parakeet?" p. 37.
} 
market participants and commodities came from all over the world, reflecting the flexibility of informal work in a globalizing economy. ${ }^{102}$

In eastern cities (where vast cattle lots were not readily available), 1970s flea markets often appeared in the same spaces as the old designated or de facto pushcart market zones or within market buildings. When legislation demarcated the territory of informal street economies, it helped determine where urban flea markets would flourish later in the century. The carefully planned and structured Eastern Market in D. C. sputtered out after WWI, in opposite proportion to the rise in area supermarkets, and stagnated for decades. After WWII, white flight increased, crime rates rose, and public markets across the capital foundered more than ever. Only seventeen merchants remained at the Eastern Market's once-thriving South Hall by 1957; by 1960 only the Union Meat and Southern Maryland Seafood companies remained, and these only because of a profitable wholesale business conducted from the market. In the 1960s and 1970s, other D.C. markets closed and the Eastern Market gained a handful of displaced merchants. ${ }^{103}$ But in the mid-1970s, a non-profit community art center moved into the Eastern Market and began to rent space to craft vendors. Antique dealers followed, and within a decade, a full-fledged Sunday flea market had gone a long way toward reviving a market many had written off. Farmers were drawn back to the spaces, encouraged by the foot traffic thronging the stalls filled with handcrafts, antiques, and used goods, and legitimated by

\footnotetext{
${ }^{102}$ A 2001 study of flea markets conducted by the National Flea Market Association (NFMA) concluded that new immigrants to the United States accounted for most of the flea market industry's growth in the 1980s and 1990s. These workers come from many different countrieseven borders such as the Pacific Ocean have become less of an obstacle for international travelers. An NFMA survey, also from 2001, indicates that flea market venders in California came from at least thirty-six different countries and spoke at least nineteen different languages. See Barron, interview with the author, October 30, 2006; and Barron, Email in possession of the author, July 27, 2005.

${ }^{103}$ Shepherd, When Culture Goes to Market, pp. 26-30.
} 
the growing local foods movement. Despite neighborhood organizations' attempts to keep out flea market-type sales in favor of a more gentrified appearance, this battle for control of public space was won by the small-scale vendors - and the market managers to whom they paid rent. ${ }^{104}$

\section{Conclusion: the Persistence of Schacher}

James M. Mayo relates the rise and fall of public markets to the transition of the American political economy from local mercantilism to corporate capitalism. ${ }^{105}$ As early as 1843 , Frederick Engels was already reporting the end of bargaining as a component of trade, declaring that "[p]olitical economy came into being as a natural result of the expansion of trade, and with its appearance elementary, unscientific Schacher [haggling] was replaced by a developed system of licensed fraud, an even more offensive, 'scientific' one." ${ }^{106}$ Flea markets demonstrated that Schacher, along with other colloquial trade practices, were not relegated to precapitalism. Before the emergence of garage sales in the early 1960s, flea markets were the only semi-permanent consumer sites where haggling and bartering remained commonplace in the U.S., following the establishment of non-negotiable pricing at department stores. Partly because of the maintenance of informal negotiations in exchange, anthropologists and sociologists examining public markets of various types have made the mistake of categorizing them, alongside farmers' markets, as “functional anachronisms." Outdoor settings, haggling and

\footnotetext{
${ }^{104}$ For more details on the "thirty years war" for control over the market space, see Shepherd, When Culture Goes to Market.

${ }^{105}$ On the rise and fall of the American public market, see James M. Mayo, "The American Public Market."

${ }^{106}$ See Frederick Engels, "Outlines of a Critique of Political Economy, in Karl Marx, Frederick Engels: Marx and Engels: 1843-1844, ed. Jack Cohen et al. (New York: International Publishers, 1843-1844), p. 418.
} 
bartering, and sparse corporate oversight do not make an event regressive. In fact, flea markets were very much a response to the modern social, demographic, and political situation of the early twentieth century, all of which helped determine form, location, and content. The modern appeal of haggling accounted for the outré air of flea markets, which sociologists have called "libidinous," and a "ritual and ceremonial venue for the experience of disorder."107

More than sixty years after "Thrifty Rosa" wisely composed her entire wedding trousseau from pushcart finds in the Bowery district, another bride "glowed with the secret knowledge" that her special day’s accouterment only cost $\$ 7.50$, thanks to the "local Manhattan antique flea market." 108 Secondhand exchange grew throughout the twentieth century as part of public trade, culminating in the popular establishment of flea markets. City ordinances, urban fires, town hangings, blue laws, or dying drive-inseach flea market seems to have an origin story all its own. But along with nationalist nostalgia, the burgeoning popularity of American-made crafts and antiques, and the economic necessities of the Great Depression, persistent ideals of consumer thrift and an emergent demand for creative consumerism made secondhand a permanent and principal addition to public markets in the United States.

Scholars declaring the waning of the American public market system focus on the earlier centrality of food sales. Major changes in distribution, transportation, marketing,

\footnotetext{
${ }^{107}$ John F. Sherry refers to flea markets as a "ritual and ceremonial venue for the experience of disorder" in "A Sociological Analysis," p. 28; and "libidinous" come from Les Abrams, "Urban Marketplaces and Mobile Vendors: The Flea Market in the Metropolitan Economy. A Case Study of Two Flea Markets-Aqueduct and Roosevelt Raceway Flea Markets," (Dissertation, City University of New York, 2007), p. 4.

${ }^{108}$ Marilyn Hoffman, "Flea Market: Big Business in U.S.," Christian Science Monitor 10 Sep 1976, p. 2; "Ghetto Beauty," p. E14.
} 
and sales of food threatened the continuation of urban public markets solely as suppliers of meat, fish, and produce early in the century, though that purpose would reemerge as an artisanal mode of consumption. In the meantime, secondhand commerce saved American public markets. 


\section{Chapter Three \\ "I Couldn't Even Shop When I Wanted To!"': \\ Garage Sales and the Postwar Household}

In 1972, Life Magazine cataloged the "phenomenon" that had "mushroomed throughout the nation's suburbs." Piles of old toys, chipped plates, a faded rug, pillows, aquariums, and antiquated popcorn poppers all heaped onto a manicured lawn would once have announced "that the junkman was on his way" but now "heralded the opening of a 'garage sale." "2 Twenty years before, as masses of Americans migrated from cities to suburbs, garage sales were not part of the middle-class consumer experience-but then again neither were large shopping centers or Tupperware home parties. By the end of the 1960s, all of these were well-integrated suburban pastimes. Across the board, commerce adapted to the needs of suburbanites while advocating for the demands of producers. The success of garage sales underscored the role consumers played in crafting those adjustments, as well as the incorporation of shopping into civic and political identities.

\footnotetext{
1 “Two Ford Freedom," Ford Television Commercial (Prelinger Archives, 1956), accessed March, 2012 http://archive.org/details/TwoFordFreed.

2"The Garage Sale: Finally, a Reason to Clean out the Attic," Life Magazine 73.7 (Aug. 18, 1972): 82-84.
} 


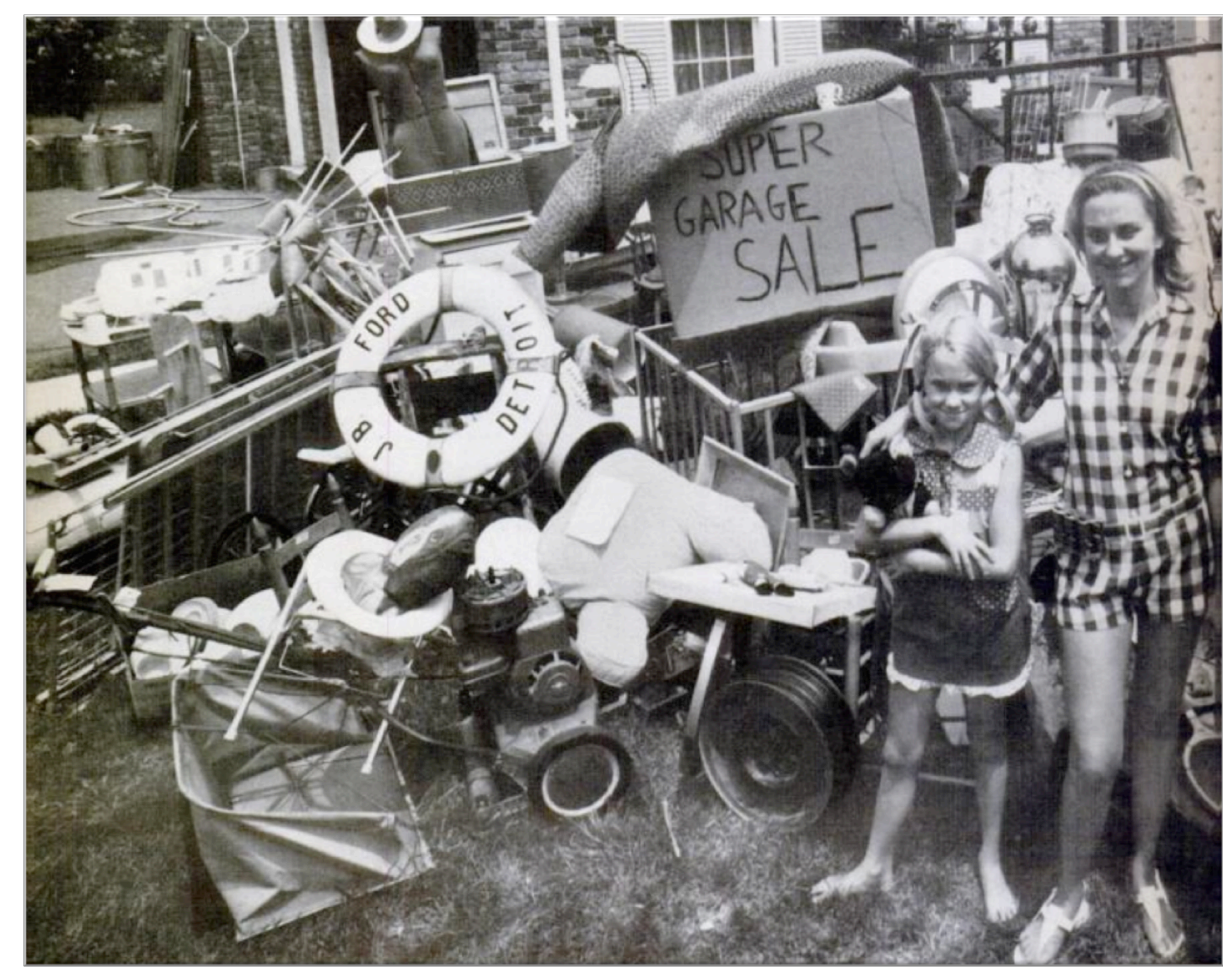

Fig. 3.1. Life

Magazine 73.7

(August 18,

1972).

Garage sales first emerged in the mid-1950s, amid the rampant building of single-

family homes in the undeveloped regions beyond cities. Also called carport sales, estate

sales, yard sales, household liquidations, moving sales, lawn sales, attic sales, cellar sales, or bargain sales, they were informal, irregularly held and privately hosted, usually in or around a single-family residence. ${ }^{3}$ Early garage sales were almost exclusively a female realm. A 1971 devotee quipped that there were only "two kinds of women in the world"- "those who go to garage sales and those who give them."4 Garage sale hostesses sold mostly used goods, sometimes supplemented with handcrafted items and comestibles. The vibe was social; browsing, bargaining, and gossiping were all quickly

\footnotetext{
${ }^{3}$ These are some of the names given in 1950s and early 1960s advertisements. Garage sale was the preferred appellation by the end of the 1960s, according to Ellen M Prohaska, "The Garage Sale: A Quasi-Economic Institution," (MA thesis: Northern Illinois University, Apr 1974), p. 1; Jean Young and Jim Young, The Garage Sale Manual: Alternate Economics for the People (Praeger, 1973), p. 1. See for examples of early advertisements: Classifieds, "Person-to Person," Orlando Sentinel 23 Jun 1956; and Classifieds, Orlando Sentinel 7 Apr 1958.

${ }^{4}$ Marian Markham, “Garage Sale,” Chicago Tribune 14 May 1967, p. E10.
} 
established as intrinsic to the practice. However, these events were more than a light means of mingling. Suburban garage sales provided a way for housewives to earn income, involve themselves in politics, and build community networks despite, though often in accordance with, the spatial circumscriptions of suburban communities and postwar gender expectations.

Garage sales highlight much that is vaunted and maligned about postwar suburbs. As mass production expanded and advertisers billed shopping as recreational, garage sales signified efforts to go beyond the spatial and aesthetic limits of suburban commercial zones such as regional malls_ one reason some anthropologists have qualified garage sales as "suburban subversiveness." The intimacy of garage sales countered trends of depersonalizing firsthand exchange. At the same time, like hostess or home parties devoted to the sale of Tupperware or Avon products, garage sales conformed to cultural assumptions of women's domestic role as mothers and wives. Garage sales supplied housewives with a small occasional income, without appearing to question the masculine position of breadwinner.

In an era of mounting civic participation, more Americans than ever before or since were joining churches, clubs and formal organizations. As fundraisers, garage sales mapped localized changes in community engagement, political activity, and charitable aide. The growth in civic associations is largely attributable to suburban women. However, men, too, at least indirectly encouraged garage sale success. Secondhand goods were raw materials for trendy home-centered hobbies, such as antiquing or collecting,

\footnotetext{
${ }^{5}$ John F. Sherry quotes "suburban subversiveness" from Roger Abrahams' undated working paper, "On Garage Sales and Other Madnesses," Department of Folklore and Folklife, University of Pennsylvania. Qtd in Sherry Jr., "A Sociocultural Analysis of a Midwestern American Flea Market," The Journal of Consumer Research 17.1 (June 1990): 28.
} 
and do-it-yourself home building and repair; thus, at least indirectly, suburban men also supported the phenomenon.

While this chapter also looks at other forms of postwar consumption and recreation to better understand the suburban secondary economy, it focuses on garage sales as a response to patterns of postwar living. Anthropologists and other social scientists have addressed these sales, and their studies agree on the centrality of social and/or recreational meaning to the practice. ${ }^{6}$ However astute, such research treats only contemporary examples. The emergence of garage sales simultaneously critiqued and affirmed broader cultural and economic trends of the 1950s and 1960s. The very timing of their appearance — at the height of American affluence — defies old assumptions that used economies were throwbacks to pre-industrial times. ${ }^{7}$ Garage sales' growth resembled the evolution of thrift stores and flea markets but even more emphatically

\footnotetext{
${ }^{6}$ Wendy A. Woloson's book on pawnshops extends to the early part of the twentieth century. See Woloson, In Hock: Pawning in America from Independence Through the Great Depression (Chicago: The University of Chicago Press, 2009). For more on existing scholarship on garage sales, see Stephen M. Soiffer and Gretchen Herrmann, "For Fun and Profit: An Analysis of the American Garage Sale," Urban Life 12 (1984): 397-421. Ruth H. Landman, "Washington's Yard Sales: Women's Work, but Not for the Money," City and Society 1.2 (Dec. 1987): 148-161; Gretchen M. Herrmann, "Gift or Commodity: What Changes Hands in the U. S. Garage Sale?," American Ethnologist 24. 4 (Nov. 1997): 910-930; Gretchen M. Herrmann, "Women's Exchange in the U. S. Garage Sale: Giving Gifts and Creating Community," Gender and Society 10.6 (Dec. 1996): 703-728; Gretchen M. Herrmann, "Negotiating Culture: Conflict and Concensus in U. S. Garage-Sale Bargaining," Ethnology 42.3 (Sumer 2003): 237-252; and Herrmann, "Haggling Spoken Here: Gender, Class, and Style in US Garage-Sale Bargaining," Journal of Popular Culture 38.1 (August 2004): 55-81; and Nurit Bird-David and Asaf Darr, "Commodity, Gift, and Mass-Gift: on gift-commodity hybrids in advanced mass consumption cultures," Economy and Society (38:2, 2009): 304-325. John Lastovicka and Karen V. Fernandez also discuss the social and individual meaning of resale in contemporary culture in "Three Paths to Disposition: The Movement of Meaningful Possessions to Strangers," The Journal of Consumer Research 31.4 (March 2005): 813-823.

${ }^{7}$ Flea markets and garage sales in this country have been referred to, respectively, as "functional anachronisms" and "vestigial archaic marketplace[s]." See Russell Belk, John Sherry, and Melanie Wallendorf, "A Naturalistic Inquiry into Buyer and Seller Behavior at a Swap Meet," Journal of Consumer Research, 14 (March 1988): 449-470; and Roger Abrahams, "The Play of Play: The Human Encounter," paper presented at the Annual Conference of the American Anthropological Association, Philadelphia, PA, 1986.
} 
accentuated the parallel success of secondhand commerce in boom times and the adaptable endurance of secondhand in general.

\section{The Suburban Home}

The geographical situation and the architectural structure of the postwar suburban home itself shaped emerging forms of consumption of both newly produced and secondhand items, as even the name "garage sale" indicates. The 1950s were the first time integral garages, or at least carports, were consistently included in home building. ${ }^{8}$ As more and more Americans relied on cars to get to work in cities remote to new suburban homes, vehicle storage became a home-building priority. Moreover, in the 1950s cars took on greater cultural importance, becoming viewed as identity signifiers for their owners. ${ }^{9}$ Suitably, cars became included in the physical household, with a specially designated space, the garage.

Automobile ownership made it possible for families to move from the city, where most employment remained. After the war, the automotive industry worked overtime to meet the backlogged needs of potential motor vehicle consumers whose acquisitiveness had been waylaid by rubber rationing and industrial preoccupation with military supplies.

\footnotetext{
${ }^{8}$ The garage in U. S. history dates back to the very beginning of the twentieth century, when rare residences of city-dwellers included "automobile houses," which ranged in type from the ramshackle to the elaborate. However, these structures were unusual and often impermanent and disconnected from the home. See Leslie G. Goat, "Housing the Horseless Carriage: America's Early Private Garages," Perspectives in Vernacular Architecture 3 (1989): 62-72, p. 62.

Developers began to include garages integral to homes, especially ranch-style houses in the early 1950s. Herbert Gottfried and Jan Jennings, American Vernacular Buildings and Interiors, 18701960, (New York: W. W. Norton \& Company, 2009), pp. 207-208.

${ }^{9}$ For more on the development of car culture in American, see David L. Lewis and Laurence Goldstein, eds, The Automobile and American Culture (The University of Michigan Press, 1980); and John Heitmann, The Automobile and American Life (Jefferson, North Carolina: McFarland \& Company, Inc, 2009).
} 
As American industries reconverted to peacetime businesses, large-scale producers capitalized on the widespread interest in new cars. ${ }^{10}$ By the mid-1950s, four out of five American families owned automobiles, and about as many new suburban homes included garages or carports. ${ }^{11}$ The government contributed to efforts of suburbanization partly through federally funding the building of highways connecting suburbs with cities. In the early days of atomic anxiety, arguments for "defense through decentralization" supported such government subsidies. When President Dwight D. Eisenhower signed the 1956 Interstate Highway Act into law, he cited quick, convenient evacuation from target areas as a major justification for the funding. ${ }^{12}$

The backlog of demand for home construction was even greater than that for cars. Similar "defense through decentralization" rationale supported aggressive government financing support for homebuyers. Thanks to cars and highways, many city employees could choose to move to these more spacious residences, and thanks to yet more federal subsidies and new liberal home loan policies, unattached, single family homes were within financial reach of more Americans than ever before. The establishment of the Home Owners Loan Corporation (HOLC) in 1933 made obtaining lifetime mortgages easier, lowering the risk of foreclosure. Along with the efforts of the Federal Housing Association (FHA) to improve mortgage plans and the Servicemen's Readjustment Act

\footnotetext{
${ }^{10}$ James J. Fink, The Automobile Age (Cambridge: M.I.T. Press, 1988), pp. 130-131; for more on reconversion, see Paul A. C. Koistinen, Arsenal of World War II: The Political Economy of American Warfare, 1940-1945 (Lawrence, KS: University Press of Kansas, 1994), pp. 445-498; For changing tactics of publicity campaigns during this period, see Cynthia Lee Henthorn, From Submarines to Suburbs: Selling a Better America, 1939-1959 (Athens, Ohio: Ohio University Press, 2006).

${ }^{11}$ Robert Genat, American Car Dealership, (St. Paul: Motorbooks International, 2004), pp. 10-13. ${ }^{12}$ Clifford Edward Clark, Jr., The American Family Home, 1900-1960 (Chapel Hill: University of North Carolina Press, 1986), p. 213; Jackson, Crabgrass Frontier, p. 249; May, Homeward Bound: American Families in the Cold War Era, (New York: basic Books, 1988) p. 151.
} 
of 1944 (or GI Bill), these federal changes made home ownership an option for many working-class citizens, as well as their wealthier peers. ${ }^{13}$

While these practices somewhat leveled the playing field across economic classes, the same cannot be said for race. Appallingly, the HOLC's and FHA's rating systems, which undervalued older, racially nonhomogeneous, or densely populated neighborhoods, erected obstacles to the movement of African-Americans and other minorities from the city to the suburb, creating de facto racial segregation in many areas. ${ }^{14}$ Despite the limited opportunities for some groups of Americans, at least 83 percent of the population growth in the United States during the 1950s was in the suburbs. ${ }^{15}$ By 1955 , the phenomenon was marked enough for panelists at the Boston Conference on Distribution to characterize suburbanization as "without question the greatest and most rapid shift in the pattern of living in history."16

Like turn-of-the-century consumers, many of whom were newcomers to American metropolises, patterns of residential relocation influenced shopping choices. As opposed to thrift store success in turn-of-the-century cities, garage sales were partly stimulated by the fact that these transplants had more rather than less room. Turn-of-thecentury cities' populations swelled with immigrants and rural migrants, and many residents lived in very tight quarters. In order to buy new, ready-made, convenient, and increasingly affordable consumer goods, these shoppers had to discard something else, as

\footnotetext{
${ }^{13}$ Kenneth T. Jackson, Crabgrass Frontier: The Suburbanization of the United States (New York: Oxford University Press, 1985), pp. 195-209.

${ }^{14}$ Jackson, Crabgrass Frontier, pp. 210-218.

${ }^{15}$ Landon Y. Jones, Great Expectations: American and the Baby Boom Generation (New York: Coward, McCann and Geoghegan, 1980), p. 38; qtd in Leerom Medovoi, Rebels: Youth and the old War Origins of Identity, (Durham, NC: Duke University Press, 2005), p. 17.

${ }^{16}$ Qtd in Gordon H. Stedman, "The Rise of Shopping Centers," Journal of Retailing (Spring 1955): 11-26, p. 11.
} 
storage was not a viable option. A steady supply of unwanted but still salvageable goods helped establish national chains of thrift stores.

Lack of space was not an immediate problem in the freshly built tract houses outside of cities. For most new homeowners in the late 1940s and 1950s, their suburban residences had considerably more space than their former apartments. In addition to more room to fill, suburbanites also had a greater variety of household goods from which to choose than their prewar counterparts, and oftentimes, an increased disposable income with which to buy. Even when cash flow was insufficient, there were remedies; the immediate postwar years brought rapidly increasing access to and use of consumer credit lines. ${ }^{17}$ Consumer spending increased 60 percent from 1945-1960. Even more impressively, spending on household goods, from appliances to televisions to furniture, increased by 240 percent. ${ }^{18}$ So even though suburban families did have space in which to store unused or outdated items, before long these spaces, too, were overstuffed. By the mid-1950s, when garage sales began to be advertised in newspapers, new goods had edged out old items, which filled the garage or attic. The space available made it possible for a single family to acquire and retain enough unwanted items for a stand-alone salethough garage sales also occasionally involved multiple families, whole neighborhoods,

\footnotetext{
${ }^{17}$ In the postwar years leading up to 1950 , the annual growth rate of consumer credit was more than $50 \%$. In the decades that followed, this rate varied, leveling off in years of recession and expanding in years of economic stability and growth. See George Kozmetsky, Piyu Yue, The Economic Transformation of the United States, 1950-2000: focusing on the technological revolution, the service sector expansion, and the cultural, ideological, and demographic changes (Purdue University Press, 2005), p. 406. For more on the postwar proliferation of credit cards and consumer credit spending, see also Lewis Mandell, The Credit Card Industry: A History (Twayne Publishers, 1990).

${ }^{18}$ Amber Watts, "Remaking Consumer Culture," in Dana Alice Heller, ed. The Great American Makeover: Television, History, Nation (New York: Palgrave MacMillan, 2006), p. 151; See also Ann Satterthwaite, Going Shopping: Consumer Choices and Community Consequences (New Haven and London: Yale University Press, 2001), p. 119.
} 
or members of civic organizations, increasing their value as community-building ventures, as discussed below.

Why not just throw or give these things away? William $\mathrm{H}$. Whyte, one of the most outspoken contemporary critics of postwar American life, declared that as "a normal part of life, thrift now is un-American" in a 1956 Fortune magazine article titled "Budgetism: Opiate of the Middle Class." ${ }^{19}$ Whyte's assessment, which assumed that rising credit debt and diminished savings accounts signaled a forfeiture of responsible personal control over finances, failed to consider practices such as garage sales and the overall rise in secondhand consumerism. Rather than simply tossing excess goods out, some housewives flung open garage doors and invited neighbors in to rifle through their discarded belongings for modest profit. Thrift as a value did not disappear with the diminishment of its immediate necessity. Frugality espoused by older generations or learned during the Great Depression was elevated to the level of patriotism during World War II. Housewives were "enlisted" into war efforts as "militant consumers" whose "budget is their battle plan. ${ }^{, 20}$ Messages of community aide and good stewardship were not wholly discarded but rather, tailored to postwar affluence.

Simply giving away large quantities of old belongings was not easy at the dawn of postwar suburbia. Neighborhoods were assembled rapidly, and other community infrastructure, including shopping facilities, lagged behind homebuilding for some years. In cities, families could conveniently donate old goods to Goodwill or the Salvation

\footnotetext{
${ }^{19}$ William H. Whyte, Jr. "Budgetism: Opiate of the Middle Class," Fortune (May 1956): 133 137, 164-167, p. 133, qtd in Elaine Tyler May, "The Commodity Gap: Consumerism and the Modern Home," in Consumer Society in American History: A Reader (Ithaca and London: Cornell University Press, 1999), p. 298.

${ }^{20}$ Helen Dallas, How to Win on the Home Front, Public Affairs Pamphlet No. 72 (New York: Public Affairs Committee 1942), p. 1-3, qtd in May, Homeward Bound, pp. 63-64.
} 
Army, but such thrift stores did not immediately appear in suburbs, nor did convenient pick-up routes extend to the freshly minted communities. By the end of the $1950 \mathrm{~s}$, however, the growth of these markets demonstrated the rise in both supply and demand of used goods; Goodwill Industries tripled their number of stores that decade. ${ }^{21}$ The lag time between a critical mass of stockpiled unwanted goods and the spread of Goodwill Industries, Salvation Army, and other thrift stores to the suburbs encouraged the emergence of garage sales as an alternative secondhand exchange system—one fittingly centered on the increasingly important family home.

\section{Allying Work and Shopping in the Suburbs}

So-called "shadow economies" like thrift stores, flea markets, and garage sales echoed the trajectories of firsthand commerce throughout much of the twentieth century. At the turn of the century, nascent thrift stores received an infusion of donations partly due to a rise in large-scale production and increased consumer access to a greater variety of new consumer goods. Housewives were more likely to discard clothing and household items that in previous decades they may have repaired or repurposed. Trends of disposal and resale also changed after World War II's end. Many American consumers who had faced wartime rationing and scarcity on the heels of a worldwide depression were eager to replace the old, comparatively worn items with which they had long been making do, as the government formally urged (see Fig. 3.2). A wide array of tempting new products emerged from reconverted factories, and full national employment assured a strong cohort of shoppers. Urging along this capacity to buy, promoters of many consumer

\footnotetext{
${ }^{21}$ Horace Warren Kimbell, This Is Goodwill Industries: An Address at New York (New York: The Newcomen Society in North America, 1962), pp. 7-8.
} 
goods followed the lead of the automobile and fashion industries by making planned obsolescence part of their marketing schemes. ${ }^{22}$

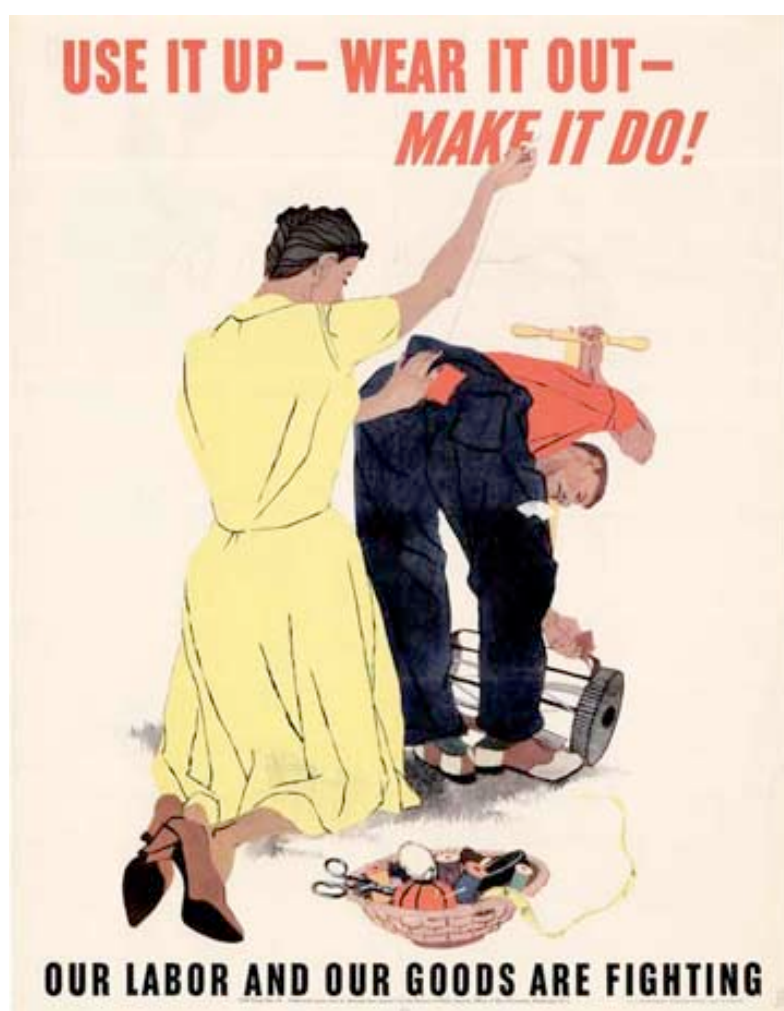

Fig. 3.2. Powers of Persuasion: Poster Art from World War II. "Use It Up-Wear It Out-Make It Do!"Nat'1 Archives and Records Administration (NARA). 1941-1945

However, for pioneer postwar suburbanites, new goods were not always conveniently available. Until the mid-1950s, suburban shopping options were limited. Though new residents had expansive consuming needs and increased resources, few early developers of suburban communities took consumer demands into immediate consideration. ${ }^{23}$ Many suburbanites of the 1940 s and early 1950 s had to drive miles to get

\footnotetext{
${ }^{22}$ Much scholarship on the 1950s emphasizes the proliferation of new goods in the $1950 \mathrm{~s}$, including those based on plastics innovated for wartime technologies. See Jeffrey L. Meikle, American Plastic: a Cultural History (New Brunswick: Rutgers University Press, 1995) and William H. Young with Nancy K. Young, The 1950s (Westport, CT: Greenwood Press, 2004), p. 45; for more on planned obsolescence, see Giles Slade, Made to Break: Technology and Obsolescence in America (Boston: First Harvard University Press, 2007).

${ }^{23}$ Some early exceptions include Lakewood, California, whose profitable regional shopping mall was erected within walking distance of the subdivision housing. Looking ahead to area development, builders also included 10, 580 parking spaces. See Dolores Hayden, "Building the
} 
to the nearest "market town" or return to the city in order to make family purchases.

While most men still worked in the city all day, the suburbs usually bounded the quotidian activities of housewives since the family car ferried the husband to his job.

Even when the car was available, urban commercial districts were not designed to accommodate the newly automobile-dependent shoppers and so provided inadequate parking. $^{24}$

As is the pattern with second hand, garage sales echoed certain developments and adaptations in various firsthand economies but also countered others. For example, the regional shopping centers that blossomed in the 1950s and 1960s suburban areas signified increasing depersonalization and corporatization of consumer facilities. Garage sales, featuring personal interactions, haggling, bartering, socializing, and even politicking, inverted the trend toward mass customer service. The intimacy of garage sales, however, replicated another rising sales trend of the postwar era: home parties, most popularly featuring Avon or Tupperware products. These money-earning social events acclimated suburban housewives to the idea of selling to each in their own homes.

The types of primary businesses established in suburbs were not just extensions of existing commercial models but innovations that accommodated America's new

\footnotetext{
American Way: Public Subsidy, Private Space," Unpublished paper delivered at the International Panning History Society conference, Barcelona, Spain, July 17, 2004, repr. in Becky M. Nicolaides and Andrew Weise, eds., The Suburb Reader (New York: Routledge, 2006), pp. 278279. See also Joel Garreau, Edge Cities: Life on the New Frontier (New York: Doubleday, 1991). ${ }^{24}$ Lizabeth Cohen, "From Town Center to Shopping Center: The Reconfiguration of Community Marketplaces in Postwar America," The American Historical Review 101.4 (October 1996): 1050-1081, pp. 1075-1077; For details on how issues of parking were sometimes dealt with in cities transformed by suburbanization, see see Richard W. Longstreth, City Center to Regional Mall: Architecture, the Automobile, and Retailing in Los Angeles, 1920-1950 (Boston: Massachusetts Institute of Technology, 1998), pp. 3-18; Parking was often considered a prime reason for loss of city business to such facilities. See "Urgent Parking Need," in New York Times (Jul 17, 1958), p. 26.
} 
economic standards and demographic situation. At the end of WWII, only a few hundred regional shopping centers - the original malls — existed in the United States. Before long, businesses fought to tap into the enormous, growing consumer demand in the suburbs. In the mid-1950s, these outlets began peppering the landscape. Frequently, these complexes were situated to serve several prefabricated communities at once, in order to maximize profit - thus, driving was usually still required (bus systems were sometimes manipulated so as to exclude poor minorities whose business was not considered ideal to center developers). ${ }^{25}$ By 1958, developers had erected 2,900 centers nationwide; by 1963, 7,100; and by the end of the 1970 s, more than 22,000 regional shopping centers provided for outlying communities. Many of these centers had from fifty to more than one hundred stores, including chain and department stores. ${ }^{26}$

While shopping centers often emulated urban downtowns, they also represented a major shift from public to privatized shopping. Though city department stores are sometimes imagined as one step in this direction, even major ones continued to tie commercial activities to the immediate community, through health fairs, planning boards, charities and events such as Macy's Thanksgiving Day Parade. Also, department stores were situated amidst public activities surrounded by pedestrian sidewalks and busy streets, bars, hotels, post offices, and courthouses. Early shopping centers, though they

\footnotetext{
${ }^{25}$ Cohen, "From Town Center to Shopping Center," p. 1060.

${ }^{26}$ Growth began in earnest in the mid-1950s. See "Six Shopping Centers will Open by 1957," Chicago Daily Tribune, p. B5.Cohen, "From Town Center to Shopping Center," p.1052; by the 1960s, many centers were planned with upwards of 100 retail stores; see "Shopping Marts Get Bigger in Suburbs," New York Times (Sept, 1956), p. R1; "Vast Shopping Center with 100 Retail Units Planned by Store in the Suburbs of Detroit," New York Times (Jun 4, 1950), p. R1; see also Richard Longstreth, The American Department Store Transformed, 1920-1960 (New Haven: Yale University Press, 2010), pp. 169-172; and Satterthwaite, Going Shopping; By the end of the twentieth century, shopping malls were joined by corporate headquarters and office and industrial parks to comprise what urbanist Joel Garreau calls "edge cities." See Garreau, Edge City.
} 
tried to incorporate community events, faced obstacles in creating environments where shoppers might gather to socialize. Some larger plans included community activity centers and childcare provision catering to the consumer needs and recreational desires of housewives, the malls' largest audience, and their families. ${ }^{27}$

Before long, though, it was clear that most centers failed to provide community cohesion or to fully integrate socialization into the shopping experience. ${ }^{28}$ City planner Ann Satterthwaite points out that "sociability became a casualty" of mainstream commerce by the late 1950s, partly because shopping center developers did not build simply for one or even for existing neighborhoods. Chain stores needed large selling areas in order to efficiently use their mass merchandising methods, and large-scale development was further encouraged by the hefty acreage needed for ample parking spaces. Fueled by federal tax policies encouraging commercial real estate development in greenfield locations, builders paved remote cornfields in anticipation of subdivision expansion. Soon, suburbs were following the shopping centers. These proactive practices hobbled organic community integration. ${ }^{29}$

Rather than further impersonalizing the experience of buying, garage sales upped the intimacy of shopping by inviting consumers into the home, or at least the semi-private extension of it: the garage, driveway, porch, or front yard. Garage sales welcomed critical examination of personal, sometimes sentimental items. A love of bargains or a

\footnotetext{
${ }^{27}$ Cohen, "From Town Center to Shopping Center," pp. 1063-1064. See also, Cohen, $A$ Consumers' Republic: The Politics of Mass Consumption (New York: Knopf, 2003).

${ }^{28}$ Cohen, "From Town Center to Shopping Center"; and Longstreth, The American Department Store Transformed, p. 170; some attempts at community integration were more successful than others. Victor Gruen, a Viennese architect created imaginative shopping centers with community and cultural activities central to his plans, following European models. Gruen's ideals survive to some extent in especially well-designed centers. See Satterthwaite, Going Shopping, pp. 109-111. ${ }^{29}$ Satterthwaite, Going Shopping, p. 100; Hayden, "Building the American Way, pp. 278-279.
} 
fashionable ardor for collecting were obvious motivators for shoppers, but one avid 1967 garage sale goer - averaging ten sales a week in the peak months of April and Mayinsisted she was not alone in adding curiosity among her reasons for this pastime. She insisted the offered items revealed intimate details about their owners' lives, at least when browsing was coupled with the ability to analyze material goods. "With hair dye and face lifting, you can’t always tell a woman's age. But a pretty good indication of how long she's been married comes from her furniture. Is it fumed oak or limed oak? Either one gives her away."30

Additionally, the private setting of garage sales was an obvious convenience to the seller. She freed herself of burdensome items, earned a little money, and possibly helped less affluent neighbors by passing along gently used goods at a fraction of their market value, all from the relative comfort of her garage or front yard. While those studying garage sales later in the century downplay the importance of income to garage sale hostesses, an early 1970s study revealed that earned income was at least a partial motivator. By this time, periodic economic recessions probably heightened the association of garage sales with financial gain, but pressures to maintain increasing standards of living dated back to the 1950s and 1960s, when rising numbers of housewives began working outside the home at least part time. ${ }^{31}$

Immediately after WWII, many working women-about 2 million of the 6 million employed in wartime - had surrendered their paychecks in favor of marriage and children. The marriage age decreased and the birth rate rose. However, the attitudes and realities about women working outside the home shifted again somewhat in the $1950 \mathrm{~s}$. In

\footnotetext{
${ }^{30}$ Markham, "Garage Sale," p. E10.

${ }^{31}$ Prohaska, The Garage Sale, p. 30; May, Homeward Bound, pp. 75-76.
} 
1958, the National Manpower Council argued that women workers were necessary additions to workplaces. By 1960, the number of wives working outside the home exceeded 30 percent — though about 80 percent of women's jobs were "pink-collar" jobs, employment stereotyped as female, which included clerks in retail outlets and other consumer-related functions. $^{32}$

An increase in consumer spending and a rise in pink-collar jobs coincided. The 30 percent of American housewives who sought employment often looked for part-time work when children were in school, or nights and weekends, when working husbands could take over. Throughout the 1950s, the increase in non-urban, regional shopping centers mirrored the increase in working wives and mothers. In 1957, a Stanford Business School professor assured managers of chain store branches that most suburban stores have access to "a large number of housewives and nonemployed women who have been willing to work." These arrangements furthered business's interests; by employing many part-time workers, store managers avoided doling out fulltime benefits and could more easily staunch union growth. ${ }^{33}$

Polls taken of those employed wives showed that about half were working in order "to buy something." "34 The desire for material acquisitions extended to less conventional types of employment as well. It echoed in the personal stories of

\footnotetext{
${ }^{32}$ For more on women and work outside the home in America, see Alice Kessler-Harris, Out to Work: A History of Wage-earning Women in the United States (New York: Oxford Publishing Press, 1982), p. 203; Susan Hartmann, "Women's Employment and the Domestic Ideal in the War Years," in Joanne Meyerowitz, Not June Cleaver: Women and Gender in Postwar America, 1945-1960 (Temple University Press, 1994), p. 86; Brian Greenberg, Linda S. Watts, and Richard A. Greenwald, Social History of the United States: The 1900s (Santa Barbara: ABC-CLIO, Inc., 2009), p. 87;

${ }^{33}$ L. Clinton Oaks, Managing Suburban Branches of Department Stores (Stanford, Calif., 1957), 73; Cohen, "From Town Center to Shopping Center," pp. 1075-1077.

${ }^{34}$ May, Homeward Bound, pp. 75-76.
} 
Tupperware saleswomen and distributers throughout the 1950s, 1960s, and 1970s. Lavon

Weber ventured into the field because she coveted a blonde coffee table, and, as she put it, an extra like that "was not on the list." ${ }^{35}$ In order to earn the money herself, either in an area where pink-collar jobs were scarce or in a way that did not go against ideals of domesticity, Weber and thousands of other women became Tupperware party hostesses.

These home parties or "hostess parties" appeared as newly discovered, quaint yet modern, social yet productive, housewife activities. Even husbands reluctant to have working wives acceded to such a feminine and sociable event as a Tupperware party. Home parties were a solution to the tension between the societal ideal of women focusing their attentions on the home and the increasing consumer imperatives. Some women, like Brownie Wise herself, head of the Tupperware sales division and mastermind of the "party plan" marketing system (and the first woman to appear on the cover of Business Week magazine, in 1954), were divorced and lacked the skills or opportunity for lucrative income elsewhere. Many of these women had the added responsibilities of single parenthood. $^{36}$

Tupperware did not become a renowned product until Brownie Wise established the party plan system. Companies like Tupperware, Avon, and Stanley Home Products,

\footnotetext{
${ }^{35}$ Kathy Bates, Tupperware! directed by Laurie Kahn-Leavitt (Crossroad Films, 2004); See also Alison Clarke, Tupperware: The Promise of Plastic in 1950s America (Washington and London, 1999); for a critical exploration of the party plan system in general, see L. Susan Williams and Michelle Bemiller, Women at Work: Tupperware, Passion Parties, and Beyond (Boulder, Colorado: Lynne Rienner Publications, 2011).

${ }^{36}$ Brownie Wise appeared on the cover of Business Week on April 17, 1954. Information on Tupperware party hostesses from Bates, Tupperware!; and Clarke, Tupperware, p. 84. Hostess parties were not only advantageous for wives and mothers, but also for the companies hiring them. After more than sixty years of employing door-to-door saleswomen, Avon's most successful decade for growth was clearly the 1950s, when sales multiplied five-fold by relying solely on direct sales. In 1953, Avon Products, using only direct sales, garnered more than three times the profits than their major retail outlet competition, Helena Rubenstein. Laura Klepacki, Avon: Building the World's Premier Company for Women (Hoboken, NJ: John Wiley \& Sons, 2005), p. 24.
} 
saw suburbia as the ideal scouting place for both party hostesses and product consumers. Wise described the suburb as "a picnic ground for direct selling," citing the "increase in household expenditure, women doing their own housework, and child-centered consumption" as prime reasons for success. ${ }^{37}$ As in-home sales, hostess parties may well have paved the path for garage sales. Before that, however, direct sales parties sought the company of other types of secondhand commerce - the two were sometimes merged. In addition to in-home gatherings, Tupperware hostesses were encouraged to seek out community events in the society pages, with the recommendation of combining a Tupperware party with "a bake sale, a white elephant sale, a rummage sale, or bazaar."”38 Three of these sales featured used goods and usually supported community groups, such as churches, sororities, or charities.

Ever the critic, Whyte cited commercial "parties" as an example of coffeeklatching conformity and "lowest denominator-seeking" among suburban housewives. Whyte and other detractors considered such "neighborism" to be disingenuous and intellectually homogenizing. ${ }^{39}$ But at-home money-making schemes were not just opportunities for dulling neighborhood gossip. They were examples of conciliatory resistance to gendered family arrangements, in which the financially responsible husband drove to work in the morning and the domestically inclined wife tended home and children. Integrating work with the duties of caring for home and family, which overcame material obstacles like childcare, circumvented concerns about feminine breadwinning.

\footnotetext{
${ }^{37}$ Clarke, Tupperware, p. 100.

${ }^{38}$ Tupperware: A Household Word in Homes Everywhere!, product catalog (Orlando, F1.: Tupperware, Home Parties, 1957), p 24; Clarke, Tupperware, pp.110-111.

${ }^{39}$ William H. Whyte, "How the New Suburbia Socializes," The Essential William H. Whyte (New York: Fordham University Press, 2000), p. 38.
} 
Garage sales had many things in common with home parties, most notably the private home location and the timing of emergence and popularity. Little evidence of the term garage sale, or associated terms, existed in the early 1950s. Like home parties, socialization and profit were both motives. In the suburbs of DeKalb, Illinois, most hostesses, some of whom had been conducting sales semi-regularly since the early 1960s, did not work outside the home. Several reported feeling "guilty about not being able to make a cash contribution to the family income." 40 Garage sales' profit-making potential was signaled in more formal ways, too. By the late 1960s, local legislation in many parts of the country regulating frequency, size, and taxation of the events indicated that the sales had become an effectual enough means of income to attract official attentionpossibly through the notice of more formalized competing businesses, such as established and taxed secondhand stores and antiques shops. As had previously happened with rummage sales, pushcart peddling, and flea markets, zoning requirements, and limits on garage sales' recurrence were established in many areas by $1970 .^{41}$

Suburban consumer venues privatized and feminized shopping. Large shopping centers were privately owned and had stricter limitations, even in the outdoor portions, on public discourse and activity than downtown shopping areas in cities. Owners catered to women, targeting them as their primary shopping demographic — even, patronizingly, increasing the size of parking spaces in order to accommodate female drivers. ${ }^{42}$ Home

\footnotetext{
${ }^{40}$ Prohaska, The Garage Sale, p. 30.

${ }^{41}$ Prohaska, "The Garage Sale: A Quasi-Economic Institution," pp. 22, 33; "Hearing Slated on Garage Sale Plan," Los Angeles Times 16 Feb 1971, p. SF6; "Wrong Zoning: City Moves Against Illegal Garage Sales," Los Angeles Times 23 Nov 1970, p. SF6; "Garage Sale Laws Will Be Studied," Los Angeles Times 9 Mar 1971, p. SF7. In 1973, Kiplinger's Personal Finance reported that Dallas, TX, and Joliet, ILL, both limit sales to two a year, per person. See Kiplinger's Personal Finance (July 1972), p. 36.

${ }^{42}$ Cohen, "From Town Center to Shopping Center," p. 1064.
} 
parties, as female-run and held in private homes even more starkly represent the trend toward privatized and feminized sales. Secondhand, through garage sales, kept pace with the changes, combining and reforming aspects of postwar consumerism to suit the needs and limitations of suburban housewives — needs that were not only monetary but also social, communal, and political.

\section{Civic Involvement}

As anthropologists Gretchen M. Herrmann and Ruth H. Landman point out about garage sales later in the century, such ventures were not only (or maybe even primarily) for personal profit. ${ }^{43}$ By at least partially relocating community sites of secondhand exchange from public spaces to nearer the private realm of home, the act of divesting unwanted goods was transformed into a directly personal affair, as opposed to an anonymous donation. Even when motivated by personal profit, some hostesses saw the events as benefitting individuals in need. Respondents to one survey suggested that needy recipients would feel better having paid a small price rather than having accepted charity. And for some, by the early 1970s, suspicion of the institutions controlling charity made garage sales' more direct interactions with needy community members preferable to the increasingly bureaucratic working of the Salvation Army or Goodwill. ${ }^{44}$ The satisfaction of monetary gain and the more individualized mode of home sales made garage sales an attractive alternative to thrift store donation, one that could still be imagined as charitable.

\footnotetext{
${ }^{43}$ Herrmann, "Gift or Commodity"; Herrmann, "Women's Exchange in the U. S. Garage Sale"; and Landman, "Washington's Yard Sales."

${ }^{44}$ Prohaska, The Garage Sale, p. 37.
} 
Indeed, while supplementing the postwar family income was one motivation for early garage sale hostesses, charity work, political fundraising, neighborly socializing, and other civic pursuits compounded the sales' community importance. Little surprise, as contemporaries studying 1960s suburbs called them "hotbeds of participation" and labeled community members "hyperactive joiners." ${ }^{, 45}$ Much of this increase in civic activity is attributable to housewives; women organized charity clubs, political groups, Parent Teachers Associations, and Neighborhood Watch Groups, to name only a few organizations whose membership skyrocketed in the decade and a half after the end of WWII. Additionally, churches and synagogues expanded community functions, creating youth programs, recreational outlets, and social events. Church membership rose from 64.5 million in 1940 to 114.5 million in $1960 .^{46}$ By the mid $1950 \mathrm{~s}$, community involvement was widely recognized as an important facet of ideal suburban life. And like their close relatives rummage sales and church bazaars, garage sales combined commercial exchange with civic involvement, and in convenient proximity to the family home. $^{47}$

As with commerce, limited mobility circumscribed housewives' community activities, spurring innovation and encouraging neighborhood-centered interactions. In the early 1950s, Ford Motors recognized the restraints of a single-car household in the

\footnotetext{
${ }^{45}$ See William Whyte, The Organization Man (New York: Simon and Schuster, Inc, 1956), pp. 287, 300, 380; Herbert Gans, The Levittowners: Ways of Life and Politics in a New Suburban Community (New York: Pantheon Books, 1967); Robert D. Putnam, Bowling Alone: The Collapse and Revival of American Community, (New York: Simon and Schuster Paperbacks, 2000), p. 209; May, Homeward Bound, p. 20.

${ }^{46}$ Some of these groups peaked early, like the General Federation of Women's Clubs, whose decline began in the mid-50s, while many others peaked in the early or mid-1960s. Putnam, Bowling Alone, p. 55.

${ }^{47}$ For more on American bazaars and fairs of various sorts, see Beverly Gordon, Bazaars and Fair Ladies: The History of the American Fundraising Fair, (Knoxville: the University of Tennessee Press, 1998).
} 
suburbs, marketing a second car as a means of increased civic and social involvement for housewives. One television ad shows a pretty young mother accepting a social invitation over the telephone. After hanging up, she tells viewers that before her husband bought a second car, she could not have accepted the summons. "I was practically a prisoner in my home," she pouted. "I couldn't get out to see my friends, couldn't take part in PTA activities—well, I couldn't even shop when I wanted to!"48

These three activities—-shopping, socializing, and participating in community events - were the bread and butter of daily life in the suburbs, and not coincidentally, the three defining purposes of garage sales. Proximity to the home was important because despite Ford's bid in these early ads, most Americans managed their hyperparticipation without an additional vehicle. In 1969, the majority of households still had only one car. Getting a second car became considered a necessity rather than a luxury sometime in the 1970s and 1980s, after garage sales already were established localized venues for socialization, shopping, work, civic interaction and even political advocacy. ${ }^{49}$

In fact, contrary to Ford's advertising claims, scholars posit a long-term correlation between an automobile-dependent society and decreasing community involvement, in the last decades of the twentieth century. Kenneth T. Jackson has argued that a "major casualty of America's drive-in culture is the weakened 'sense of community." ${ }^{50}$ Possibly, though, limited access to automobiles contributed to increased community involvement, partly because more planning and firmer commitment was necessary. For example, carpooling created mutual dependence, making it more difficult for an individual to skip an event once obligated.

\footnotetext{
48 “Two Ford Freedom," Ford Television Commercial.

${ }^{49}$ Putnam, Bowling Alone, p. 212.

${ }^{50}$ Jackson, Crabgrass Frontier, p. 272.
} 
Centering civic involvement on the home encouraged participation for more reasons that just mobility. As Elaine Tyler May argues, the anti-Communist Cold War policy of "containment" was reflected in the retreat of the family unit to their own private spaces for both physical and ideological security. ${ }^{51}$ For Jackson also, the American home replaced a nebulously defined "sense of community" that he has argued the era's drive-in culture eradicated: "The real shift, however, is the way in which our lives are now centered inside the house, rather than on the neighborhood or the community. With increased use of automobiles, the life of the sidewalk and the front yard has largely disappeared, and the social intercourse that used to be the main characteristic of urban life has vanished. . There are few places as desolate and lonely as a suburban street on a hot afternoon." 52 Saturday morning in prime garage sale season, however, was anything was desolate. Garage sales straddled public and private space, and extended from inside the home to out in the street and community-literally spilling the personal contents of private life outside. Even as the home became more central to all aspects of life, it was also provisionally opened to the public, as a means of work and even as a way to further personalize political engagement. As historians Lisa McGirr and Matthew Lassiter argue, housewives' coffee klatches in this era provide a popular setting for the suburban grassroots politicking that spawned new conservatism. ${ }^{53}$

Like all forms of exchange, twentieth-century community fundraising suffered in lean economic times. During both the Great Depression and World War II, church

\footnotetext{
${ }_{52}^{51}$ May, Homeward Bound, especially pp. 15-18.

52 Jackson, Crabgrass Frontier, p. 272.

${ }^{53}$ See Lisa McGirr, Suburban Warriors: The Origins of the New American Right (Princeton, NJ: Princeton University Press, 2002); and Matthew D. Lassiter, The Silent Majority: Suburban Politics in the Sunbelt South (Princeton, NJ: Princeton University Press, 2006).
} 
bazaars and rummage sales declined in number and popularity. ${ }^{54}$ Thrift stores and other forms of secondhand sales similarly suffered from lack of product. When President Roosevelt, in 1934, announced his request to the Boy Scouts to collect used clothing and household materials in order to give free to the nation's needy, the Salvation Army helped with these efforts for more than altruistic reasons. So few items - in such bad shape-were coming their way through the usual routes that it had become a challenge to provide clothing even for the men working in the salvage centers. The Salvation Army was partly encouraged to help with the drive by the promise to keep surplus goods. ${ }^{55}$ Problems acquiring secondhand clothes and other goods for resale continued after the United States joined the war effort in 1942. Government-sponsored war propaganda urged personal conservation through posters like that shown in Figure 3.2, resulting in fewer quality secondhand goods to donate. A similar pattern emerged with church bazaars, club rummage sales, and other civic fundraisers. During WWII, ladies societies and church groups rerouted fundraising energies to help provide for soldiers or for citizens of war-torn countries abroad. In several instances, multiple groups had to join forces in order to accumulate enough goods to sell. War relief shops substituted for fundraising fairs across the country, featuring gently used and handmade items. ${ }^{56}$

Almost as soon as the war ended, community fundraising fairs returned with a renewed vigor - again, like thrift stores. After the war's end, the Salvation Army and Goodwill grew bigger and stronger than ever before. Goodwill's earned income, in real

\footnotetext{
${ }^{54}$ Gordon, Bazaars and Fair Ladies, p. 186.

${ }^{55}$ E. H. McKinley. Somebody's Brother: A History of the Salvation Army Men's Social Service Department (Lewiston: The Edwin Mellon Press, 1986), p. 97.

${ }^{56}$ If enough used goods donations were received, societies would feature white elephant sales with international themes (like the Orient). See Gordon, Bazaars and Fair Ladies, pp. 183-184.
} 
dollars, increased by a full $580 \%$ between $1948-1966 . .^{57}$ The frequency and size of bazaars and rummage sales rose at the same time as the flourishing of community clubs, church membership, and other organizations. In 1955, McCall's full-length guide to bazaars insisted that there "has never been a money-making method so ideally suited" to all organizations as the bazaar. ${ }^{58}$ Groups that had previously hosted bazaars returned to the practice with new zeal and increased bounty in foods, themes, and homemade and recycled goods. Other groups held fundraisers for the first time, including churches and synagogues and homemaker's clubs, who billed their efforts as in the spirit of community building. ${ }^{59}$

Considering the popularity of rummage sales and bazaars, garage sales may seem redundant or selfishly motivated, but garage sales shared their civic role with bazaars and rummage sales in the postwar era without diminishing the importance of any of them. Instead, each specialized. After garage sales invaded suburbia, handmade items, family activities, and comestibles increasingly replaced used goods in other public fundraisers. The form of these fundraisers remained consistent and expanded, while the content shifted. ${ }^{60}$ By the early 1960 s, the goods offered seemed to determine nomenclature. The appellation "garage sale" indicated mostly used goods, even when the event was held at a public venue or organized by a community group. For example, in 1958, The Lyre of Alpha Chi Omega announced the results of a rummage sale. Just five years later, the

\footnotetext{
${ }^{57}$ Grimm, "Working with Handicaps," pp. 54-58.

${ }^{58}$ Numerous postwar guides and resources for organizing bazaars were published. See Ruth $\mathrm{H}$ Brent, "The Big Club Bazaar," Good Housekeeping (September 1956), p. 142; Janet Suzanne Benton, "a Modern Story of Loaves and Fishes," American Home (Sept. 1954) pp. 12, 14-15; Harriet Hawes and Eleanor Edelman, McCall's Complete Book of Bazaars (New York: Simon and Schuster,1955); and Gordon, Bazaars and Fair Ladies, p. 186.

${ }^{59}$ Gordon, Bazaars and Fair Ladies, p. 186.

${ }^{60}$ Gordon, Bazaars and Fair Ladies, pp. 192-195.
} 
same publication reported a successful "Garage Sale," which was held at the same location and offered similar sorts of donated used items as the 1958 sale. Other events called rummage sales or bazaars increasingly featured handmade items such as macramé pieces, placemats and potholders, Christmas ornaments, and sentimental crossstitchings. ${ }^{61}$

As civic involvement increased throughout the 1950s and 1960s, the society pages of newspapers reported garage sales whose profits supported clubs, societies, and churches. Garage sales also served as political fundraisers. Garage sales in Los Angeles suburbs raised funds for both the Democratic and Republican parties, with Republican women's clubs slightly more abundant. Events were held at individual homes but often represented groups - such as the Brentwood Republican Women's Club Federated,

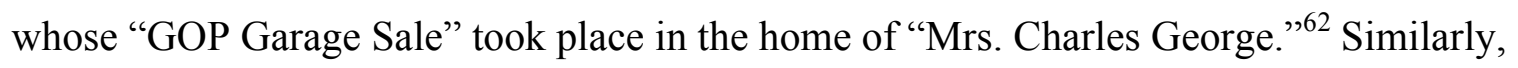
the Aug 24, 1967 "Datebook" section of the L.A. Times reported a "pool, lawn, and garage sale" held by the Palisades Republican Women's Club Federated. This sale was also held in the private home of a club member. ${ }^{63}$

Garage sale fundraisers supporting Democratic candidates often involved young participants. Although contemporary studies and anecdotes reported limited garage sale activity among youth before the mid-1970s, electoral fundraisers were an exception, attesting to a rise in political involvement among new voters. ${ }^{64}$ In 1968, a garage sale was one fundraising event in addition to bake sales, house cleaning, and soda bottle

\footnotetext{
${ }^{61}$ The Lyre of Alpha Chi Omega 61.4 (December 1958), p. 55; and The Lyre of Alpha Chi Omega 67.2 (March 1963), p. 1; Gordon, Bazaars and Fair Ladies, pp. 194-198.

62 “GOP Garage Sale," Los Angeles Times, 22 Oct 1970, p. W59.

63 "Datebook: Garage Sale Set," Los Angeles Times, 24 Aug 1967, p. W59.

${ }^{64}$ Anecdotal exceptions involving entrepreneurial pre-teens exist. See Prohaska, The Garage Sale, pp. 26, 27.
} 
collecting, all organized and run by high school and college students. The proceeds went toward the Democratic Presidential nomination of Sen. Eugene McCarthy. ${ }^{65}$ Sometimes the liberal candidate supported was notably young, too. In Montana, a garage sale helped fund Dorothy Bradley's successful bid for state representative. Described as "an attractive 23-year-old ecological activist and Phi Beta Kappa graduate in archeology,” Bradley was the only woman elected to the Montana House of Representatives in 1970. Her platform, environmentalism, dovetailed with her fundraising tactic; Democratic women in her district helped her coordinate a huge garage sale, touted as a means of reuse and environmental stewardship as well as a practical means of financial support. ${ }^{66}$ By 1970, secondhand commerce was for some affiliated with the goals of the nascent environmental movement. Garage sales were posited as responsible consumerism, a type of recycling.

Clearly, suburban housewives' limited access to automobiles did not solely account for garage sales' rising popularity. Arguably, the family car was available on weekends (and was often used by organized garage sale shoppers), but even then, driving all the way to the city in order to buy, discard, or sell used goods was inconvenient compared to these neighborhood sales. Garage sales connected grassroots efforts to strengthen neighbors' economic standing, promote civic organizations and build political networks. They did not represent a full retreat to the home or a forfeiture of former systems of community support, like church rummage sales or bazaars. Rather, when part of formal organizations such as women's clubs and churches, garage sales served as a personalized, home-centered expansion of community fundraising.

\footnotetext{
65 "Students Backing McCarthy Bake, Sweep, Clean for Gene," Chicago Tribune, 3 Aug 1968, p. 7.

66 “They Fight Against Pollution,” Chicago Tribune, 13 Dec 1970, p. G10.
} 
Decades-old practices of donating unwanted goods to community charity bazaars and other secondhand fundraisers acclimated women (and some men) to the idea of moral and civic good associated with passing along gently used goods.

Garage sales reflected the rise in grassroots politics and a personalization of civic engagement, one centered on neighborhoods and individual homes. Garage sales also indicated the diversification of community fundraisers. Bazaars and rummage sales in the 1960s and after increasingly reflected the growing arts and crafts movement, reminiscent of the similar Progressive-era trend when amateur artisanship and home crafting were also valued and the products deemed saleable — many times through female-run charitable bazaars. ${ }^{67}$ Garage sales, in turn, dominated the market in used goods for community sales. Home crafting and other postwar hobby trends were connected to garage sale growth in ways other than the changes in rummage sale content. Since secondhand materials were often useful in popular do-it-yourself projects, garage sales supplied crafters with raw materials for their hobbies.

\section{Collecting and Do-It-Yourself}

So far, it may seem that women were solely responsible for the existence of garage sales. While it is true that most direct participants originally were female, men's interests and lifestyles fueled the sales' growth in the 1960s and 1970s. As has been pointed out by consumer historian Mark Swiencicki, even when women served as the

\footnotetext{
${ }^{67}$ T.J. Jackson Lears writes on the antimodernist implications of the Arts and Crafts movement in America at the turn of the twentieth century; see Lears, No Place of Grace: Antimodernism and the Transformation of American Culture, 1880-1920 (Chicago and London: The University of Chicago Press, 1981); see also Steven Gelber, Hobbies: Leisure and the Culture of Work in America (New York: Columbia University Press, 1999), p. 5.
} 
primary buyers for the home, they did not consume everything they bought. ${ }^{68}$

Secondhand materials were no exception. Men as well as children and other family members benefitted from the purchase of pre-owned household goods, and from any profit attained from the sale of the same. But garage sales also provided a specialized resource connected to a rise in hobby pursuits, including collecting and antiquing, which rose in popularity as a recreation.

These "do-it-yourself sales" contributed to another increasingly popular hobby: do-it-yourself home handcrafts and building. While "DIY" included both men and women among its numbers, men especially took to repairing and crafting home goods with a new fervor in the postwar era. ${ }^{69}$ Suburban men's reasons for home construction were various - money saving, pleasure, and an eagerness to "achieve something different." Whatever the motive, a 1955 Better Homes and Gardens survey showed that 63 percent of home buyers did some construction and 23 percent did all. ${ }^{70}$

In 1973, Kiplinger's Personal Finance called garage sales “a new American institution." ${ }^{71}$ By this time it is likely that an erratic economy and mounting consumer credit debt meant that real fiscal necessity or at least anxiety spurred some of the attention to informal economic resources, but Kiplinger's does not overlook the

\footnotetext{
${ }^{68}$ Mark A. Swiencicki differentiates between "buying" and "consuming" and other ways that men participated in consumer culture in the decades around the turn of the last century. See Swiencicki, "Consuming Brotherhood: men's Culture, Style and Recreation as Consumer Culture, 1880-1930,” Journal of Social History 31.4 (Summer 1998): 773-808.

${ }^{69}$ Kiplinger's Personal Finance: Changing Times (July 1973), p. 36; Gelber, Hobbies, pp. 268294.

${ }^{70}$ See Cohen, "A Middle-Class Utopia? The Suburban Home in the 1950s," in Making Choices: A New Perspective on the History of Domestic Life, ed. Janice Tauer Wass (Springfield: Illinois State Museum, 1995).

${ }^{71}$ Kiplinger's Personal Finance, p. 36.
} 
recreational aspects of the business, well established by this time. The article bids sellers to beware they know the value of potential collectibles, as many buyers certainly will. ${ }^{72}$ After WWII, interest in collecting expanded as more Americans could afford the leisure and expense of antique shopping. But like consumption in general, collecting also changed, becoming more democratic by including common manufactured items and not just high-end antiques. Postwar museums such as the Strong Museum in Rochester, New York, and the Lightner Museum in St. Augustine, Florida, celebrated everyday items like toys and shaving mugs, elevating the quotidian to new cultural heights. An emphasis on design in new manufactured goods encouraged and reflected the same consumer interest in distinction that spurred antique collecting. Thomas Hine dubbed the 1960s "the Populuxe era," and pointed out that object design, "from salt shaker to house," included elements of fantasy and personalization. Populuxe, a contraction of "popular" and "deluxe," suggests the process of democratizing luxury. ${ }^{73}$ Coupled with the perception of shopping in general as recreation, consumers' awareness of the aesthetic details of everyday objects meant that buying second hand could signal personal creativity rather than indicating need. Therefore, even those without the means to frequent expensive auctions could pursue inexpensive collecting or distinctive decorating through secondhand venues like garage sales.

The significance of secondhand shopping as recreational is apparent in media sources of the 1950s and 1960s. Auctions were portrayed as respectable and amusing outings for both men and women —often, as something a couple could enjoy together as part of a personally fulfilling relationship. The Du Pont ad in Figure 3.3 addressed men,

\footnotetext{
${ }^{72}$ Kiplinger's Personal Finance, p. 36.

${ }^{73}$ Gelber, Hobbies, p. 66; Thomas Hine, Populuxe (New York: Alfred A Knopf, 1986), p. 11.
} 
telling them, "Enjoy a day rambling through the country together, like you've promised yourself for so long. Your wife has a baby-sitter. And you have the time- thanks to Du Pont LUCITE House Paint."74
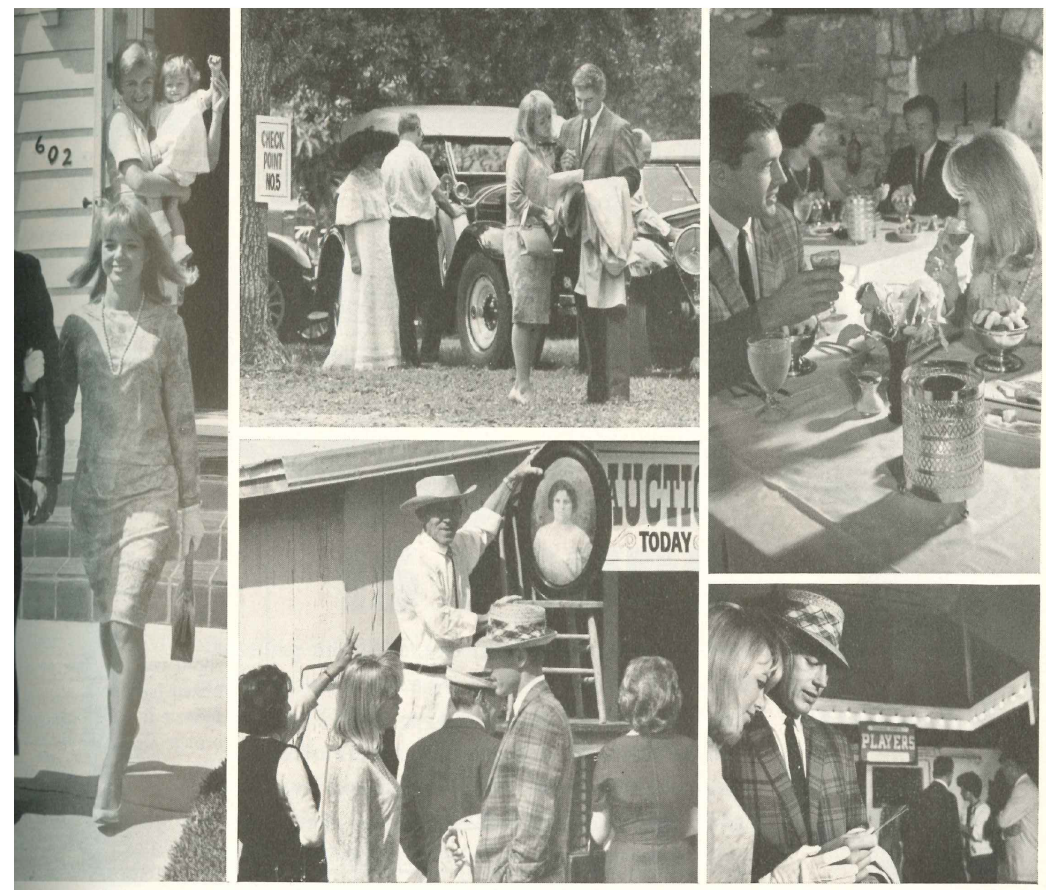

\section{Have some fun before the show, too}

Du Pont LUCITE ${ }^{\oplus}$ House Paint gave you the whole day

Fig. 3.3. DuPont advertisement, Better Homes and Gardens, Vol. 43, No. 8 (Aug. 1965)

This Better Homes and Gardens ad illustrates several relevant recreational trends, as well important expectations of masculinity in the domestic sphere. First of all, Du Pont addresses the man of the house, assuming that it is his weekend task to paint the house, reflecting the rise of do-it-yourself homebuilding and maintenance. Additionally, the postwar era emphasized familial closeness; friendship, camaraderie, and shared interests became important aspects of a successful marriage and a secure home life. The couple's

\footnotetext{
${ }^{74}$ Better Homes and Gardens 43.8 (August 1965), p. 101.
} 
outing includes not only an auction but also what appears to be an antique car show, illustrating the prevalent interest in material objects of previous generations as well as the romanticizing of automobiles. $^{75}$

Aesthetically, decorating with choice collectibles pointed to a desire for personalized style in an era dogged by assumptions of conformity and homogeneity in both popular and historical imagination. Some critics of suburbia argue that aggressive corporate tactics and the increased number of "necessities" in the American middle-class culture of mass consumption led to the homogenization of suburban life. At the same time, though, suburban residents were pursuing hobbies and recreations with a new ardor that belied this supposed disintegration of stylistic variety. Personalizing a new home exemplified individualization, as well as a connection to something beyond newly manufactured products. $^{76}$

A 1957 short story in Ladies' Home Journal shows that homeowners wanted their personal possessions to be significant and distinctive. In "The Chippendale Chest," a young wife bemoans her desire to replace her furnishings with "beautiful, priceless, authentic antiques." The current tables, chairs, and sideboards were "awful" because "they don't mean anything." 77 Although the young couple struggled with finances, they managed to scrape up enough, together, to place a winning bid on a small, highly desired Chippendale chest and individualize their new suburban home with an object that was not manufactured in a newly reconverted factory but reflected something about their own

\footnotetext{
${ }^{75}$ Better Homes and Gardens, Vol. 43, no. 8 (Aug. 1965), p. 101.

${ }^{76}$ Lizabeth Cohen asserts that suburbanites used consumerism "to express their individuality as much as their conformity in the homes they created." See Cohen, "A Middle-Class Utopia?", p. 10 .

${ }^{77}$ Elizabeth Dunn, “The Chippendale Chest," Ladies' Home Journal, (Oct. 1956), pp. 128-133, 135. Italics in the original.
} 
lives, signifying a belief in their own identities as distinctive through the acquisition of a presumably unique object.

In addition to coveting unusual collectible or antique items, postwar Americans also expressed opposition toward new, mass-manufactured goods and against the stultifying repetition of the middle management labor that accounted for more and more American jobs through building, repairing, or modifying home furnishings and accents and other crafting pursuits. Horace Coon, who wrote about postwar hobbies at the time, cited the monotony of and lack of creativity in contemporary work as motivation for the do-it-yourself trend. Hobbies in general provided an "escape," and crafters especially, were "rebels" against hegemonic industrialism. ${ }^{78}$ As paid labor became more and more abstracted from physical final products as the country moved toward service-oriented industries, DIY tasks provided an antidote by making goods production a healthful hobby rather than a livelihood.

Historically, both men and women collected—at times, more men than women. But the do-it-yourself trend was much more closely associated with men. The DIY craze, which included household repair work, furniture building, kits, and many other handicrafts, was depicted as a return of traditional values, to a deeply rooted American spirit of independence and ingenuity. However, as historian Steven M. Gelber shows, before the Great Depression, it was uncommon for middle-class men to take such an interest in the state of his dwelling. Nineteenth century couples were far more likely to hire experts for even the simplest fix or improvement. ${ }^{79}$ Our Du Pont-buying, auction-

\footnotetext{
${ }^{78}$ Horace Coon, Hobbies for Pleasure and Profit: New Worlds of Fun and Relaxation for Everyone (New York: New American Library, 1955), pp. 9-11, 16.

${ }^{79}$ Steven M. Gelber, Do-It-Yourself: Constructing, Repairing and Maintaining Domestic Masculinity," American Quarterly 49.1 (March 1997): 66-112, pp. 66-67. For more on the
} 
going husband would most likely have hired a professional painter to do the job in the 1890s.

In speaking of the craze of home repair and workshop craftsmanship in 1952, Business Week Magazine called the era the "age of do-it-yourself." ${ }^{\circ 0}$ Soon, only reading and watching television were more popular as forms of recreation among married men. ${ }^{81}$ While sometimes portrayed as things a family could do together, these tended to be maledominated activities, involving dad and perhaps a trusted son. The sacred sphere of Dad's tools was even featured in popular sitcoms of the time, such as the episode 37 of Leave It to Beaver (1958), in which Beaver runs away after being reprimanded for allowing his friend to play with his father's tools, resulting in a hole in wall of - where else? - the garage. $^{82}$

Since the interstitial structures often included more room than required to house the family car or was not at all used for that purpose, garages were adapted for other uses. They were the wild card of home spaces, their application a matter of negotiation between residents. Men tinkered in garage workshops, teenage boys began garage bands, and housewives held garage sales. By the mid-1960s, Better Homes and Gardens regularly ran project suggestions_- usually addressing men — ordaining specific uses for extra garage space, like "a Playful Playroom," "a very Serviceable Sewing Room,” or the rather ambiguously designated "Good Times Room." 83

various social and economic influences on the rise of "masculine domesticity," see also Gelber, Hobbies.

80“"Personal Business," Business Week (April 2, 1955), p. 131.

${ }^{81}$ Gelber, Hobbies, 278.

${ }^{82}$ Leave It to Beaver. Episode 37, first broadcast 25 June 1958 by ABC. Directed by Norman Tokar and written by Joe Connelly and Bob Mosher.

${ }^{83}$ Better Homes and Gardens 45.8 (August 1967), p. 50; Better Homes and Gardens 51.2 (Feb 1973), pp. 1-6. 
Do-it-yourself projects like garage makeovers often entailed repurposing existing materials, like many of the "under $\$ 100$ " projects annually highlighted in 1960s" issues of Better Homes and Gardens. One suggestion from 1965 suggests the reader "[1]iberate a piece of junk and turn it into a jewel of an end table! This not-quite antique spool chest (a youngster of only 50 years) started life in a dress factory and almost ended as kindling." 84 While the cost of the goods used could be low if salvaged, in many ways do-ityourselfers practiced a form of elitist simplicity—-the flip side of Populuxe's democratic luxury. Trendy craftsmanship often required expensive tools and took the luxury of time in order to produce relatively simple objects. At the same time, the value-added of the craftwork involved in refurbishing made the purchase of a discarded item expressive of the ability to pursue a leisure activity rather than an admission of fiscal weakness.

Suburban trends in leisure and recreation helped establish garage sales as viable pastimes. One of women's chief recreational labors became shopping. Men's recreations became increasingly domestic as well, to include home repair and handicrafts, some of which validated secondhand purchases. Garage sales supported both women's pursuit of exciting and smart shopping and the masculine home crafts comprising the era's "productive leisure." $" 85$

\section{Conclusion}

Scholars have succeeded in breaking down many myths and exaggerations about conformity and homogeneity in the burgeoning suburbs of postwar America. ${ }^{86}$ However,

\footnotetext{
${ }^{84}$ Better Homes and Gardens 44.7 (July 1966), p. 56.

${ }^{85}$ Gelber refers to hobbies as "productive leisure" throughout Hobbies.

${ }^{86}$ As Kenneth T. Jackson writes, "American suburbs come in every type, shape, and size: rich and poor, industrial and residential, new and old." See Jackson, Crabgrass Frontier, p. 5.
} 
the assumption of at least one major allying factor persists: consumption. In her book on Tupperware, Alison Clarke sells her own topic short when she claims about suburban shoppers, "Old world values and diverse social backgrounds might divide them in the realm of production, but through consumption they were redefined as a culturally bound, aspiring middle-class group." ${ }^{87}$ Yet families' conversions from urban, ethnic, and working class to suburban, Americanized and middle class did not follow set paths. Hand-me-down furnishings and home building were part of the transition for many, resources and skills that carried over into established suburban lives. ${ }^{88}$ Garage sales enabled and exhibited these diverse consumer attributes.

The links between primary and secondary consumerism abound. Oftentimes, scholars portray formal, firsthand economies as monolithic, crowding out more informal means of trade, imagining secondhand exchange to be relegated to historical irrelevance by the march of post-capital commerce. But the relationship is much more layered, and informal economies much more adaptable and obdurate than this figuring allows. When historian Beverly Gordon describes what she sees as the decline of fundraising fairs after World War II, she pronounces the community aspect sacrificed to the altar of mass commerce. As an example, she points to bazaar organizers resorting to shopping malls for their events, taking their outdated affair "to the people." As a result, the groups responsible were hobbled in what items they could offer, limited to handwork and simple baked goods so as to not compete with mall retailers. To Gordon, in such gatherings,

\footnotetext{
${ }^{87}$ Clarke, Tupperware, p. 3.

${ }^{88}$ See Cohen, "A Middle-Class Utopia?" p. 63.
} 
"the community is reduced to something fleeting and illusory: it is a community of consumers." 89

By looking more closely at garage sales, however, it becomes clear that amidst jumbles of cast-offs, community, recreation, and socialization survived. Like much of white America, it adapted to the suburbs. Just outside the tract houses comprising prefabricated neighborhoods, secondhand consumerism found another home. Thrift stores accommodated and conformed to the corporate standards and limitations of urban growth. Country flea markets responded to the expanded commercial lives of rural inhabitants. And garage sales, much by way of the pursuits and desires of housewives, evolved to fit the spatial, social, and commercial constraints of suburbs.

\footnotetext{
${ }^{89}$ Gordon, Bazaars and Fair Ladies, p. 203.
} 


\title{
Part II The Use of Used
}

\author{
Fashion is modernist irony. ${ }^{1}$ \\ --Elizabeth Wilson
}

\footnotetext{
${ }^{1}$ Elizabeth Wilson, Adorned in Dreams: Fashion and Modernity (Berkeley and Los Angeles: University of California Press, 1985), p. 15.
} 


\section{Chapter Four \\ "A Utopia Would Rise Out of Garbage": \\ The Radical Fashions of Waste}

At a 1968 press event held in a New York City Montgomery Ward, acclaimed American fashion designer Rudi Gernreich scorned the popularity of used clothes“costumes from a vaudeville trunk, or great-great-grandmother's wedding dress, or flea market finds, or the rags off the backs of hippies." ${ }^{2}$ Gernreich, considered one of the most important American "anti-establishment" designers, simultaneously recognized and dismissed secondhand fashion's claim to political engagement. Romantic, historically evocative outfits, according to him, weakly protested the world's ills by "evading the issue or pretending. They're not true, by being someone else, somewhere else."33

As Gernreich's comments suggested, postwar youth sometimes viewed the use and exchange of pre-owned household goods and - particularly — clothing, as a form of activism. This claim proved vulnerable to reproach. Some detractors dismissed the importance of individual appearance (even in the context of movements giving rise to such slogans as "the personal is political") along with the seemingly paradoxical attempts at anticommercial consumption. ${ }^{4}$ For those like Gernreich, who acknowledged the political potential of individual fashion choices, charges of sartorial escapism overlooked the significance of where and how secondhand clothing was obtained. Or perhaps,

\footnotetext{
${ }^{2}$ Jean Spain Wilson, "You Don't Need a Placard With the 'Unisex' Styles," The Washington Post 24 Jun 1968, p. C3.

${ }^{3}$ Qtd in Wilson, "You Don't Need a Placard With the 'Unisex' Styles,” p. C3. For more on Gernreich, who is credited with pioneering the unisex style, see Peggy Moffitt and William Claxton, The Rudi Gernreich Book (Cologne, Germany: Taschen, 1999); and Valerie Steele, Fifty Years of Fashion: From New Look to Now (New Haven, CT: Yale University Press, 1997), p. 71.

${ }^{4}$ Radical feminist Carol Hanisch coined the phrase "the personal is political" in her 1969 essay of the same title. See Hanisch, "The Personal is Political," in Shulamith Firestone and Anne Koedt, eds., Notes from the Second Year: Women's Liberation (New York: Radical Feminist, 1970), pp. 76-78.
} 
considering the designer's vested interest in the sale of new clothing, his public derision of used materials was an indication of secondhand trade's success and its potential threat to the fashion industry.

On the one hand, some studies cast thrift-store style as a clear representation of the anti-establishment sentiments associated with the late $1960 \mathrm{~s}$, as a youth culture backlash to mass-produced clothing and to a consumeristic society. ${ }^{5}$ These generalized stories of defiance invest unexamined faith in the power of individual "rebellion" and take at face value personal accounts of the political meaning of style. On the other hand, recent scholars have reacted to similar claims of resistance by denouncing the radical potential of many cultural forms, especially describing economic resistance as short-lived and trivial. ${ }^{6}$ According to this narrative, savvy postwar admen co-opted cool and hijacked hip, bringing recalcitrant baby boomers into the industrial capitalist fold by offering mass-produced tie-dyed, ethnic-inflected, and unisex styles. ${ }^{7}$ Both of these accounts simplify the meaning of style, overlook the historical underpinnings of fashion trends, and ignore the implications of how and where objects are acquired.

\footnotetext{
${ }^{5}$ For a typical example, an encyclopedia of youth culture reports that "[a]mong the young the wearing of old clothes was intended as an anti-establishment comment, a reaction to the new throw-away attitude that came along with the explosion of mass-produced clothing in the 1960s." See Shirley Steinberg, Priya Parmar, and Birgit Richard, Contemporary Youth Culture: And International Encyclopedia, Vol 2 (Westport, CT: Greenwood Press, 2006), pp. 392-3; Edward G. Reilly, The 1960s (Westport, CT: Greenwood Press, 2003), 87; Claudia A. Mitchell and Jacqueline Reid-Walsh, eds. Girl Culture: an Encyclopedia (Westport, CT: Greenwood Press, 2007), p. 499.

${ }^{6}$ Angela McRobbie proposes shopping and fashion often remain excluded from conversations about radicality because scholars dismiss them as intrinsically frivolous and therefore regard mention of the association as potentially compromising to radical status. See McRobbie, "Second-Hand Dresses and the Ragmarket," in Angela McRobbie, ed., Zoot Suits and Secondhand Dresses: An Anthology of Fashion and Music (Boston: Unwin Hyman, 1988), p. 34.

${ }^{7}$ See for example, Thomas Frank, The Conquest of Cool: Business Culture, Counterculture, and the Rise of Hip Consumerism (Chicago and London: The University of Chicago Press, 1997); and Leerom Medovoi, Rebels: Youth and the old War Origins of Identity, (Durham, NC: Duke University Press, 2005).
} 
In the decades after World War II's end, white, middle-class youth bought, sold, stole, traded, borrowed, gleaned, decorated with, and wore secondhand items with increasing frequency and visibility. As a deviation from middle-class modes of shopping and appearance, buying and displaying pre-owned goods made manifest postwar insecurities over the cultural position of the middle class amid anxieties of possible nuclear war, increasing class conflict, Civil Rights, U.S. involvement in Vietnam, and second-wave feminism. Moreover, secondhand consumerism expressed social opposition to a variety of political issues and capitalist priorities, and also forwarded practical solutions, through modes of consumption as well as the performance of dress and style.

Through Beat writings and in beatnik communities, advocacy of secondhand commerce helped construct images of class merging, and foreshadowed the coming environmental movement. The Beats' heirs, hippies, while popularly credited with popularizing secondhand style, relied on many of the same avenues of and motives for used goods commerce as the Beats, though forging fashions in aesthetic opposition to media portrayals of beatniks. In "dressing up" to have a "grand time," Victorian-andEdwardian-clad hippies established secondhand trade as intrinsic to countercultural economies. $^{8}$

Secondhand consumerism, perceived as bypassing capitalist consumer routes, gained appeal among activists as national attention to domestic poverty and opposition to U.S. involvement in Vietnam both rose. As the 1960s ended, feminists seeking to avoid an oppressive and dictatorial fashion industry relied on used goods to circumvent at least the most immediate of fashion's demands. And as the environmental movement drew

\footnotetext{
${ }^{8}$ For Haight-Ashbury's premier fashion designer Linda Gravenites, looking "strange or beautiful or medieval or American Indian" was about having a "grand time" and pleasing oneself. See Joel Lobenthal, Radical Rags: Fashions of Sixties (New York City: Abbeville Press, 1990), p. 114.
} 
upon radical momentum to gain public attention for the ecological repercussions of overconsumption, the Diggers and related anarchic activists saw the mountains of refuse as raw material for nonmonetary utopian societies. Taken together, these interests posited secondhand consumption as a way to increase comfort, sustenance, and pleasure in newly forged communities.

Yet, despite articulated notions of the radicalism of secondhand, members of elite groups and proprietors of high-end department stores pioneered the idea of secondhand clothing as objects worth collecting, following trends in antique furnishings and automobiles. If anything, the idea of "vintage," or valuable, clothing was co-opted from mainstream consumer sources and impressed into the service of countercultural and radical ideals. For example, West coast hippies combined elements of Old West fashion and secondhand clothing to create a fashion recognized as socially radical. The craze for older Americana styles extended to firsthand mass clothing production much earlier in the interwar period. Companies began making nostalgic western wear for the public in the 1920s, decades before the 1960s San Francisco hippie incorporation of Old West outlaw aesthetics. ${ }^{9}$

What Dick Hebdige refers to as "the conversion of subcultural signs (dress, music, etc. . .) into mass-produced objects (i.e., the commodity form)" was never total in the case of secondhand because the elements of the style were already mass-produced, even when repurposed or redesigned, and were already a commodity form. ${ }^{10}$ In fact, secondhand became less instead of more associated with major avenues of corporate

\footnotetext{
${ }^{9}$ The production of western shirts began for Hollywood film costumes, but companies soon responded to public demand with large-scale production and distribution. See Steven E. Weil and G. Daniel DeWeese, Western Shirts: A Classic American Fashion (Layton, Utah: Gibbs Smith, 2004), p. 19.

${ }^{10}$ Dick Hebdige, Subculture (London and New York: Routledge, 1979), p. 94.
} 
marketing and distribution over time. The upsell from "old" to "vintage" began at large department stores, but separate, localized consumer streams (as well as larger networks of resale like Goodwill Industries and Salvation Army) dominated used goods sales in the 1960s and thereafter. The prices and presentation of the materials changed, but the fact of recirculation remained. The oppositional value of secondhand was complicated but never displaced by its own fashionability.

Secondhand goods were part of the substantial detritus of consumer society, and redistribution consisted of actions (buying, stealing, finding, or making) that drew from the same political economy it critiqued. Partly for this reason, the fashion and clothing industries against which those styles inveighed were easily able to mass-produce new approximations of secondhand trends. Even so, the political implications of secondhand consumerism and the actual use of secondhand materials persisted and increased throughout the 1970s and beyond. ${ }^{11}$ In Woodstock's aftermath, activist Todd Gitlin wondered whether the era's youth culture would leave behind anything but a market. ${ }^{12}$ That "market" was not just devoted to new goods. Secondhand commerce persisted and grew after 1960s youth established used goods as markers of rebelliousness. While not without contradictions and never wholly resistant of capitalist commerce, secondhand style provided a long-term model of subversive consumerism.

\footnotetext{
${ }^{11}$ Although most modes of secondhand exchange remained unquantifiable, media reports of the popularity of garage sales peaked in the 1970s, and according to the NFMA, the number of nationwide flea markets grew enormously in that decade. Of course, exact statistics on flea markets are untenable, since the definition and assessment of the venues have always been unstable. See The Flea Market Industry: Economic and Legislative Impact Data " (From the papers of Ed Collins: National Flea Market Association, 2006).

${ }^{12}$ Abe Peck, Uncovering the Sixties: The Life and Times of the Underground Press (New York: Pantheon, 1985), 226; qtd in Alice Echols, "Hope and Hype in Sixties Haight-Ashbury," Shaky Ground: The Sixties and Its Aftershocks (New York: Columbia University Press, 2002), p. 47.
} 
Imaginatively, secondhand dress was a way of engaging with what Grace Elizabeth Hale calls the burgeoning "romance of the outsider" in postwar America. Terms like "outsider" and "rebel" were in flux as relatively privileged youth adopted cultural forms — including fashion — originating from the working class and racial minorities in order to distance themselves from their inherited class positions. ${ }^{13}$ Like rock-n-roll's appropriation of black musical styles, the adoption of poor clothing, as well as Native American and Old West costumes, relied upon the white, middle-class, and usually male conviction that sincerity, depth, passion, creativity, and even social equality were more accessible from the margins of society—past and present. ${ }^{14}$ And as Hale points out, the romance of the outsider "is neither completely separate from nor completely a tool of the U. S. political economy." 15

Intrinsic to many of the fantasies embodied by secondhand style was an honorary membership in the working class - an aspect of Bohemianism that dates back to 1830s Paris, where the unabashed embrace of an appearance of poverty articulated difference from the growing bourgeoisie. A visual distinction was necessary in part because "Bohemian" and "bourgeois" were both vague, indefinable, and overlapping conceptsmuch in the same way rebels, outsiders, and the middle class interacted in changing postwar America. Jerrold Seigal defines Bohemian Paris as "the appropriation of

\footnotetext{
${ }^{13}$ Hale, A Nation of Outsiders, 5-10.

${ }^{14}$ Eric Lott describes a continuing vein of blackface minstrelsy in American culture which illuminates and affects not only racial, but class and gender, difference throughout the nineteenth and twentieth century. See Lott, Love and Theft: Blackface Minstrelsy and the American Working Class (New York: Oxford University Press, 1993).

${ }^{15}$ Grace Hale, A Nation of Outsiders: How the White Middle Class Fell in Love with Rebellion in Postwar America (Oxford, New York: Oxford University Press, 2011). 7.
} 
marginal life-styles by young and not so young bourgeois, for the dramatization of ambivalence toward their own social identities and destinies."16

Similarly, those adopting secondhand styles in the 1950s and 1960s were not forging a simple counterimage to a new American bourgeoisie. At times, secondhand goods served as material embodiments of a generational desire for the breakdown of social, as well as stylistic, categorization; as such, used items were integrated into a symbolic bricollage. Even so, secondhand styles also sometimes stemmed from nostalgia for an imagined time when class dominance or military authority ordered society, resulting in parodied images like the military costumes on the cover of The Beatles' 1967 St. Pepper album. ${ }^{17}$ Rather than being an immediate and wholesale rejection of all that was firsthand or familiar, secondhand styles became part of a mixture of old and new, masculine and feminine, expensive and cheap, exotic and ordinary, utopic and pragmatic, high-end and street-born, and past and future.

Elective participants in secondhand commerce critiqued a consumer-based culture without fully abdicating their preordained roles as consumers. For these patrons, consumer dissidence consisted of what, where, and how much to acquire, but not usually whether. For children raised in America's new postwar suburbs, the modes of acquisition — scavenging for vaudeville trunks, rummaging through flea market wares, or exploring aged relative's attics — were important oppositional acts whatever the materials attained. Buying from places like thrift stores defied the middle-class standards of earlier generations still able to recall the material deprivations of the Great Depression and World War II, and for whom a place like a Salvation Army store was "a terrifying

${ }^{16}$ Jerrold Seigal, Bohemian Paris: Culture, Politics, and the Boundaries of Bourgeois Life, 18301930 (New York: Penguin, 1986), p. 11.

${ }^{17}$ See McRobbie, "Second-Hand Dresses and the Role of the Ragmarket," pp. 25-26. 
reminder of the stigma of poverty, the shame of ill-fitting clothing, and the fear of disease through infestation."18 Moreover, through the act of purchasing secondhand, middle-class "rebels" upended the accepted order of class charity, wherein they offered donations and members of poorer classes accepted them. From contemplation to purchase to performance, secondhand style involved much more than simply "being someone else, somewhere else.”

\section{“Bohemia is always yesterday." $"$-Malcolm Cowley}

The excavation of retired fashions did not start with hippies - or with the Beats, or even in the twentieth century. Both borrowing from past styles and romanticizing poverty have been part of identification with Bohemianism since its mid-nineteenth-century appearance in response to modern industrialization and consequent changes in the production of art. ${ }^{20}$ The cultural myth of the Bohemian sought "to reconcile Art to industrial capitalism, to create for it a role in consumer society." Accordingly, the myth of the bohemian established art as both part of and separate from commerce and consumption, and ascribed a lofty status to the economic instability of an artist's path, commensurate with ideas of artistic genius and the solitary labor of creativity. ${ }^{21}$

\footnotetext{
${ }^{18}$ Angela McRobbie's exploration of secondhand commerce in postwar Great Britain emphasizes the monetary, entrepreneurial advantages to secondhand market participation, as well as the "[p]attterns of taste and discrimination [that] shape the desires of second-hand shoppers." McRobbie concluded that secondhand London markets provided financial opportunities for those without entrée to mainstream retail. In the U.S. context, I argue that aesthetics and politics were primary motivations among participants in used goods exchange, in the context of a singularly robust economy. See McRobbie, "Second-Hand Dresses and the Ragmarket," qt from p. 29. ${ }^{19}$ Malcolm Cowley, Exile's Return: A Literary Odyssey of the 1920s (orig. published 1934; London: The Bodley Head, revised ed., 1964), p. 62.

${ }^{20}$ For more on this relationship, including the disappearance of patronage of the arts, see Elizabeth Wilson, Bohemians: The Glamorous Outcasts (New Brunswick, New Jersey: Rutgers University Press, 2000), pp. 15-27; see also Seigal, Bohemian Paris, pp. 1-30.

${ }^{21}$ See Wilson, Bohemians, p. 3.
} 
The equation of an artist's life with poverty emerged alongside the figure of the Bohemian, whose prototype was sketched in 1840s Paris through Henri Murger's autobiographical Scènes de la vie de Bohème..$^{22}$ This particular brand of destitution was not born strictly of misfortune or mindful thrift, but of a reckless intemperance inspiring wild flings of "ruinous fancy, loving the youngest and prettiest, drinking the oldest and best," followed by a necessary return to "that table spread by chance.",23 Thrift and conformity in appearance were bourgeoisie traits antithetical to creative abundance, an outlook deafeningly resonant among an important minority of postwar American youth.

Among European Bohemians, public appearances reflected historical nostalgia and respect for the creative ablution of a destitute life. Mid-nineteenth-century Bohemian styles were often flamboyant, colorful, and excessive, set off by romantic medieval touches. Theatricality, fueled by the popularity of costume balls and inviting historical dress references, influenced daily wear for self-proclaimed outsiders. But in a converse yet equally performative style, humble dress also reigned among some factions: Champfleury commented in 1855 , “Today poverty forms the basis of the painters' costume. . . only ancient hats, jackets and trousers stained with oil, and shoes whose owners tremble at the least sign of rain." 24

With 1910s Greenwich Village, the U.S. acquired an official Bohemian headquarters, the first in a series of urban areas economically undesirable enough to provide cheap housing and culturally central enough to attract a Bohemian cohort. The turn-of-the-century industrial boom bypassed the winding Greenwich Village streets in

\footnotetext{
22 In Virginia Nicholson, Among the Bohemians: Experiments in Living, 1900-1939 (London, New York: Penguin, (2002), p. 3.

${ }^{23}$ Murger qtd in Virginia Nicholson, Among the Bohemians, 3.

${ }^{24}$ Champfleury, Les Excentriques (Paris: Michel Levy, 1855), 230, qtd in Wilson, Bohemians, pp. 163-164.
} 
favor of New York City's more predictably gridded areas, leaving its quaint, low-rent meanderings to impoverished modernists. ${ }^{25}$ Mostly from at-least middle-class backgrounds, Greenwich Village artists and intellectuals were unabashedly intrigued by the habits and styles of their working-class neighbors, echoing European cross-class emulation. $^{26}$

By the 1920s, Village characters were celebrated and caricatured in cartoons, film, song, verse, and prose. The subject of Fanny Brice's 1922 recorded hit song, "Rose of Washington Square," was the "queen of the models" in the Bronx who wandered "down to Washington Square/and Bohemian Honky Tonks." There, her "Roman nose" pleased her "artistic" Beaux who wore "secondhand clothes,/and nice long hair."27 The same album also included one of Brice's most enduring hits, "Second Hand Rose."

${ }^{25}$ See Wilson, Bohemians, p. 41. See also Christine Stansell, American Moderns: Bohemian New York and the Creation of a New Century (New York: Henry Holt and Company, 2000).

${ }^{26}$ According to Joanne Meyerowitz, bohemian communities of the time expanded their ideas of sexual possibility not only by browsing the 'highbrow' writings of sexologists but also by observing the 'lowbrow' behavior of their less educated neighbors. See Meyerowitz, Women Adrift: Independent Wage Earners in Chicago, 1880-1930 (Chicago: University of Chicago Press, 1988), p.116. Much Village clothing reflected Progressive political ideology as well as elective poverty. Village women's dress was strongly influenced by feminist ideology, stressing free public discourse and social and sexual equality. For more on the dress and philosophy in the Village before the 1920s, See Deborah Saville, "Dress and Culture in Greenwich Village," in, Linda Welters and Patricia A. Cunningham, Twentieth-Century American Fashion (New York: Berg, 2005 pp. 33-56. Patricia A. Cunningham examines women's dress reform in Europe and the U. S. in the industrial age, styles that influenced women's dress in the Village. See Cunningham, Reforming Women's Fashion, 1850-1920: Politics, Health, and Art (Kent \& London: The Kent State University Press, 2003). For more on the aesthetic movement in America, see Mary Warner Blanchard, Oscar Wilde's America: Counterculture in the Gilded Age (New Haven and London: Yale University Press, 1998). The health and aesthetic justifications for dress reform in this era were often elided. See Ken Montague "The Aesthetics of Hygiene: Aesthetic Dress, Modernity, and the Body as Sign," Journal of Design History 7.2 (1994): 91-111.

${ }^{27}$ Ballard MacDonald and James F. Hanley, "Rose of Washington Square," (New York: Shapiro, Bernstein \& Co., 1920), MCNY; Emily Kies Folpe, It Happened in Washington Square (Baltimore: The Johns Hopkins University Press, 2002), p. 9. 
Together, these two songs connected Bohemian Greenwich Village to the surrounding area's predominantly Jewish trade in secondhand clothing. ${ }^{28}$

Fanny Brice was born Fania Borach (1891-1951) in New York City, the third child of parents of Hungarian-Jewish descent. Brice dropped out of school in 1908 to begin performing in a burlesque revue and was soon headlining for the Ziegfeld Follies. Through Ziegfeld's shows, Brice introduced both of the "Rose" songs and in 1921, secured a deal with Victor Records. Rose was based on a real-life Jewish art model in the Bronx - the songwriters transferred their subject to Greenwich Village, figuring the Bohemian enclave a more fitting setting. ${ }^{29}$ "Rose of Washington Square" epitomized the unconventional life of the 1920s Greenwich Village Bohemians for generations of Americans, and periodically reappeared along with filmic retellings of Brice's own life and her several interesting marriages. ${ }^{30}$

"Second Hand Rose" furnished the first Rose with a backstory. In this song (which shares a writer with "Rose of Washington Square"), Rose good-naturedly bemoans her fate as the daughter of a used-goods dealer: "Father has a business, strictly second hand./Ev'rything from toothpicks, to a baby grand./Stuff in our apartment, comes

\footnotetext{
${ }^{28}$ Grant Clarke and James F. Hanley, "Second Hand Rose," (New York: Shapiro, Bernstein \& Co., 1921), MCNY.

${ }^{29}$ Barbara W. Grossman, Funny Woman: the Life and Times of Fanny Brice (Indiana University Press, 1992), pp. 118-119.

${ }^{30}$ Though Washington Square was once considered separate from Greenwich Village, the two became interchangeable by the 1920s. See Folpe, It Happened in Washington Square, p. 9. The plot of the 1939 film Rose of Washington Square, was inspired by Brice's career, as well as her marriage to a professional gambler who served fourteen months in Sing Sing prison for wiretapping and three years in a federal penitentiary for Wall Street bond theft (Brice won an invasion of privacy suit for this production). The Broadway musical Funny Girl (1964) fictionalized Brice's life and was made an award-winning movie starring Barbra Streisand in 1968. For more on Brice's life and romantic entanglements, see Herbert G. Goldman, Fanny Brice: the Original Funny Girl (New York: Oxford University Press, 1992); Grossman, Funny Woman; and Arnold Shaw, The Jazz Age: Popular Music in the 1920's (New York: Oxford University Press, 1987), esp. pp. 117-125.
} 
from Father's store,/Even things I'm wearing, someone wore before./It's no wonder that I feel abused./I never have a thing that ain't been used." ${ }^{\prime 1}$ Everything in Rose's life is second hand —including her "man," who has been married before. Everyone knows she's secondhand Rose, from Second Avenue. Like the "Roman" nose, Rose's secondhand status is an indication of somewhat fashionable Bohemian ethnicity. Moreover, Second Avenue - where Brice's mother, coincidentally named Rose, and father, first set up their household — was in a respectable section of the Lower East Side that would become a hub of Jewish culture in the early 1900 s. ${ }^{32}$ For listeners who might not pick up on these subtleties, Brice's comically Jewish accents and liberal peppering of Yiddish surely clued them in.

Second-Hand Rose may have established the national idea of a Village resident as stylishly down-at-the-heels and ethnically exotic, but some of its real inhabitants were quite a bit more experimental. The most outlandish dresser of the epoch was probably the Baroness Elsa von Freytag-Loringhoven. The German-born, Dadaist artist and poet lived in the Village and used collected refuse in her work and personal attire. She recycled all manner of materials for sculptural assemblages and dressed in ways that extended her art to her body, adapting "found"—-sometimes stolen—objects to her body. She made a dress from funeral crepe, wore birdcages as necklaces, skirts, or bras, and accessorized her bustle with a battery-operated taillight. ${ }^{33}$ The Baroness's habit of gleaning was endemic among European and American surrealists and highlighted a fascination with urban

\footnotetext{
${ }^{31}$ Clarke and Hanley, "Second-Hand Rose."

${ }^{32}$ Goldman, Fanny Brice, p. 8.

${ }^{33}$ See Ross Wetzsteon, Republic of Dreams: Greenwich Village, The American Bohemia, 19101960 (New York: Simon \& Schuster, 2002), pp. 318-319. For more on artists living in the Village during and after World War I, see Steven Watson, Strange Bedfellows: The First American Avant-Garde (New York: Abbeville Press Publishers, 1991).
} 
detritus that would inspire generations of New York avant-garde artists. ${ }^{34}$ For these gleaners, discarded goods provided not only creative inspiration but also a storehouse of actual materials.

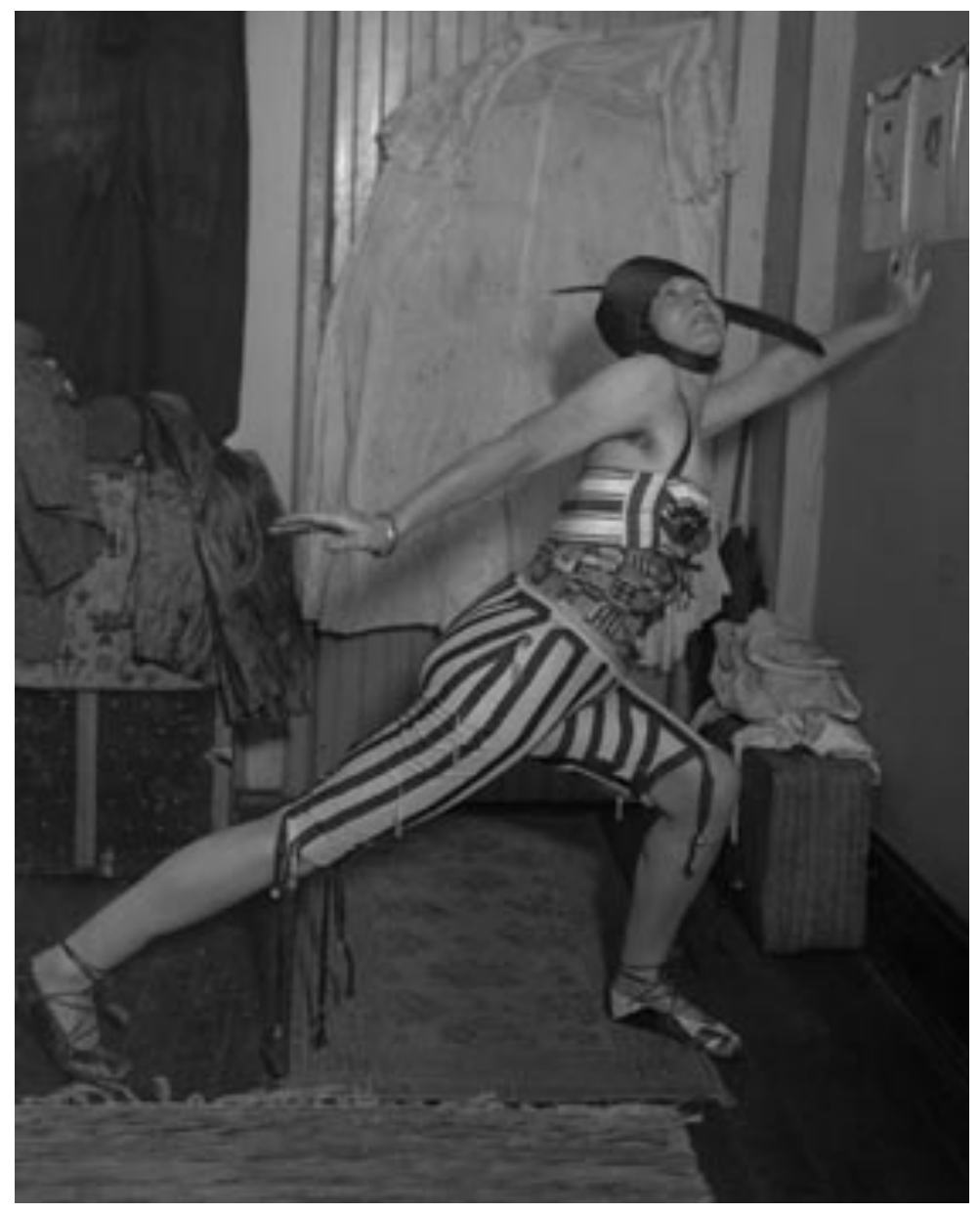

Figure 4.1. Baroness Elsa von FreytagLoringhoven in her Greenwich Village apartment, 1915. Photo courtesy of Francis N. Naumen Fine Art.

In a pattern that would repeat, the Village's first phase of shabby fashionability was relatively short-lived. By 1920, rent around Washington Square had tripled, and the Village had become a tourist destination. The commodification of Bohemian style provided single women with rare business opportunities running teahouses, hat and batik

\footnotetext{
${ }^{34}$ For example, Andre Breton and Max Ernst would take other Surrealists to New York's Third Avenue junk shops, quizzing the acolytes on which objects were properly surreal. They also bought and used items in their art. See Ruth Brandon, Surreal Lives: The Surrealists, 1917-1945 (New York: Grove Press, 1999), pp. 449-450. Joseph Cornell also famously incorporated New York thrift store materials and found objects into his boxes. See Charles Simic, Dime-Store Alchemy: The Art of Joseph Cornell (New York: New York Review Book, 1992).
} 
shops, and tour guide companies. ${ }^{35}$ A 1919 faux tour guide by Greenwich Village bohemian and witty lyricist Robert Edwards poked fun at the increasing dilettantism of both male and female Village residents—and incidentally revealed a market in secondhand. In addition to listing several antique dealers in his "guide," Edwards' section "How to Be an Interior Decorator" headlined learning to "haggle with antique dealers."

Despite this growing affiliation of secondhand with Bohemia through the 1920s, during the Great Depression and World War II, the necessity for individual re-use somewhat curtailed the recirculation of goods - with the possible exception of antique collecting, as previously mentioned. The imperative for re-use within the household reaffirmed popular distaste for used goods after the war. Armed with war-bonds savings and G.I-bill educations, Americans were soon buying more new things than ever before, and clothing was no exception.

Postwar industry, technology, and culture conspired to make secondhand commerce and style a more visible mode of opposition to firsthand fashions than ever before. Unprecedented uniformity in trends and new synthetics narrowed departmentstore options. Peter York called the 1950s and 1960s fashion world "a kind of Vatican."37 The concept of obsolescence reached the fashion industry in the 1940s and 1950s as magazine editors, fashion designers, and major distribution chains - the fashion “industry"- agreed upon rapidly changing, seasonal lines. A consensus among industry leaders on suitable cuts, colors, and fabrics helped establish a trend toward greater uniformity across income groups in the types of clothing worn - tending towards a

\footnotetext{
${ }^{35}$ Saville, "Dress and Culture in Greenwich Village," p. 44.

${ }^{36}$ Robert Edwards, Bob Edwards' Guide to Greenwich Village and all through Life with Map History Directory Music Verse Pictures Advice \& Formyla for Art, Love, Etc. . (New York: The Quill, 1919), p. 27.

${ }^{37}$ Peter York, Modern Times (London: Futura, 1980), p. 10.
} 
specialization by activity and more informality in general. ${ }^{38}$ As York puts it, "the point was that everyone wore it, your sister, your auntie, the gym mistress, everyone. For truly, THERE WAS NO ALTERNATIVE." ${ }^{39}$ While this conclusion exaggerates the ubiquity of fashion's power (partly by disregarding secondhand options), the impression was one of unprecedented conformity in style.

New synthetic fabrics, many based on wartime technologies, changed the production and cost of clothing, and influenced styles, cuts, and colors, not unlike advances at the beginning of the century. Although DuPont first launched nylon in 1938, the War Production Board took over all nylon yarns for military purposes on February 11, 1942. ${ }^{40}$ After reconverting their factories for civilian production, DuPont and other companies quickly extended synthetics to other articles of clothing. Polyesters, nylons, acetates, and acrylics abounded in the 1950s, parading under numerous brand names that sounded like the cast of a science fiction novel: Dacron, Terylene, Trelenka, Orlon, Crimplene. These wool and cotton substitutes comprised dresses, shirts, blouses, and suits that could be tossed in the washer and quickly dried, requiring no ironing or extra maintenance. Many could afford more clothing, which required less care and effort than

\footnotetext{
${ }^{38}$ Clair Brown, American Standards of Living: 1918-1988 (Cambridge, Massachusetts: Basil Blackwell Inc., 1994), p. 277. A longer scope on the rise in casual and sportswear, see Deirdre Clemente, "Made in Miami: The Development of the Sportswear Industry in South Florida, 19001960," Journal of Social History, 41, No. 1 (Fall, 2007): pp. 127-148.

${ }^{39}$ York, Modern Times, p. 10.

${ }^{40}$ The wartime yearning for nylons was such that a popular song included the chorus, "I'll be happy when the nylons bloom again, cotton is monotonous to men." Within days of Japan's surrender, DuPont announced that eager civilians would have, "Nylons by Christmas!" See Susannah Handley, Nylon: The Story of a Fashion Revolution (Baltimore: The Johns Hopkins University Press, 1999), p. 48.
} 
previously. ${ }^{41}$ The visual distance between pre-and-post-war clothing designs - and between new and most secondhand-was suddenly vast.

At this same time, the mass relocation of families from cities to suburbs brought alternatives to conformity out from attics. Trunks and crates of clothing and household items carefully saved and maintained during leaner times found their way into secondhand outlets. Through expanding chains of thrift stores, newly flourishing garage sales, and multiplying flea markets, a fast-mounting repository of antiquated fashions, already noticeable for their public renunciation of new styles and synthetic fabrics designed for domestic ease, formed the sartorial basis for various youth rebellions.

Amid increasing style conformity, sheltered suburban youth encountered secondhand through approved venues, thanks to the popularity of benefits, fashion shows, and other fundraisers. Radical feminist Alix Kates Shulman's autobiographical novel Burning Questions describes a suburban rummage sale as formative in the life of her protagonist, Zane. Zane aspires to have the "life of a rebel," a quest that carries her from suburban Indiana to 1950s Greenwich Village, and from a beatnik Bohemian youth through a marriage of compromise to her eventual arrival as a key actor at the start of second-wave feminism. ${ }^{42}$

Zane's participation in her junior high rummage sale honed those nascent yearnings for rebellion. The sale was sponsored as a way to raise school funds and as a

\footnotetext{
${ }^{41}$ Handley, Nylon, pp. 112-115; William H. Young and Nancy K. Young, The1950s, (Westport, CT: Greenwood Press, 2004), p. 81. For more on the history of plastic and its production, uses, and marketing, see Jeffrey L. Meikle, American Plastic: A Cultural History (New Brunswick, New Jersey: Rutgers University Press, 1995). People had been investing a greater percentage of their income in clothing since 1935. The greatest increase in real clothing expenditure per capita in all recorded periods was between 1935 and 1950. The technological innovations and the rise in many incomes halted the increase in percentage of expenditure while continuing to increase the amount of clothing acquired. See Brown, American Standards of Living, p. 202.

${ }^{42}$ Alix Kates Shulman, Burning Questions (New York City: Alfred A. Knopf, 1978).
} 
means of "character building" for the young suburbanites. Public fundraisers demonstrated a postwar commitment to civic responsibility — and often relied on the frequent amassing and discarding of still-usable goods. But in showing white, privileged kids how "the other half lived," such charitable work also introduced suburbanites to perceptions, habits, and styles that went against suburban strictures. At the rummage sale, Zane encounters non-white, non-suburban, non-affluent people. The first aspect of "difference" she remarks on is that of fashion. The rummage sale patrons dressed in color combinations that "were forbidden" in her suburban hometown of Babylon. ${ }^{43}$

"Such combinations as green with blue, orange with red (or red with pink or pink with orange), brown with black, or purple with anything were considered quite untenable. Such breaches of taste, variously called loud, gauche, stupid, Italian, Jew, were simply prohibited without anyone's every questioning why. And now gradually the room was filling up with people who so consistently violated these simple, basic rules that one could only conclude they were unaware of it." ${ }^{, 4}$

That evening Zane lays out her cherry-red sweater and pink pleated skirt, vowing to her picture of Joan of Arc that she will "wear the forbidden combination to school." Her first deliberate act of cultural rebellion is sartorial, inspired by the rummage sale's heterogeneity. Throughout her quest for meaningful activism, Zane relies on secondhand commerce to define her own image as one anchored by defiance and originality.

\section{“Everything Belongs to Me Because I am Poor.”-Jack Kerouac}

She notes about the rummage sale, "the education of a rebel begins at home," but Zane soon left the suburbs for New York City. ${ }^{46}$ Nationwide, "white flight" from urban centers like New York City drained cities of economic resources and increased ethnic and

\footnotetext{
${ }^{43}$ Shulman, Burning Questions, pp. 27-28.

${ }^{44}$ Shulman, Burning Questions, p. 29.

${ }^{45}$ Shulman, Burning Questions, pp. 31-32.

${ }^{46}$ Shulman, Burning Questions, p. 26.
} 
racial heterogeneity in the postwar years. ${ }^{47}$ Young refugees from the isolation of the suburbs and the influences of popular mass culture filled some of that abandoned space. ${ }^{48}$ For a second time, a postwar industrial boom bypassed the Village. This time, new manufacturers looked outside of cities, and especially to the Sunbelt states. Years before the term "Beat" was brought to a broad audience in John Cllelon Holmes' 1952 article "This is the Beat Generation," a collection of college drop-outs and urban thrill-seekers recognized that while New York City (and specifically the Village) was declining economically and politically_thus providing cheap housing — its cultural influence was expanding. ${ }^{49}$

Burning Questions portrays the importance of neighborhood and housing to Bohemian identities. In considering whether to move into her first Village "quasi-legal, cold-water flat," Zane is swayed by the place's Bohemian past. The history is more than architectural — though the tin ceilings and gingerbread moldings have their own éclat. Evidence of a hip revolving-door tenancy is scattered throughout the rent-controlled walk-up: sculptures strewn about from three tenants ago, a glass bookcase with "the

\footnotetext{
${ }^{47}$ New York City was not alone; in fact, several other cities felt this drain more acutely. Many historians have explored the context and effects of white flight in the decades after World War II. See for example, Kevin Michael Kruse, White Flight: Atlanta and the Making of Modern Conservatism (Princeton, New Jersey: Princeton University Press, 2005); and Thomas J. Sugrue, The Origins of the Urban Crisis: Race and Inequality in Postwar Detroit (Princeton, New Jersey: Princeton University Press, 1996).

${ }^{48}$ Many intellectuals of the time criticized postwar mass culture; notably, members of what would become known as the Frankfurt School such as Theodor Adorno and Max Horkheimer, argued that the immersive qualities of radio and television precluded "imagination or reflection on the part of the audience." See Adorno and Horkheimer, "The Culture Industry: Enlightenment as Mass Deception," in Adorno and Horkheimer, Dialectics of Enlightenment (New York: Verso, 1997), p. 126. For more on a postwar shift to privileging individualism, see Hale, A Nation of Outsiders, pp. 36-43.

${ }^{49}$ See John Clellen Holmes, "This is the Beat Generation," Orig. publ. Nov. 16, 1952, The New York Times Magazine. In Holly George-Warren, The Rolling Stone Book of the Beats: The Beat Generation and American Culture (New York: Hyperion, 1999), pp. 6-7; William Lawler, Beat Culture: Lifestyles, Icons, and Impact (Santa Barbara: ABC-CLIO, 2005), p. 13.
} 
complete works of every writer who's ever lived here," and most appealing, a general sense of intentional unkemptness. "It's shabby disrepair had its own value: to free you of responsibility."

In the late 1940s and 1950s, the Village's "shabby disrepair" once again drew youth looking to be freed of responsibilities — of religion, family, class, or gender. Among those migrants were the poets and artists who would soon be relentlessly stereotyped and homogenized as black-wearing, cigarette-smoking "beatniks" by a simultaneously fascinated and disapproving press. ${ }^{51}$ Jack Kerouac, Allen Ginsberg, Neal Cassady, and William S. Burroughs were quickly recognized as central figures of the "Beat Generation," while women such as Joyce Johnson and Diane Di Prima, though important to the emerging literary (and sartorial) aesthetic, failed to attract the immediate approval of the androcentric group and its followers. As east coast Beats gathered in the downwardly mobile Village, North Beach in San Francisco and Venice, California, attracted similar crowds; some individuals criss-crossed the coasts in a continental pingpong game of Beat socialization like that depicted in many of Jack Kerouac's novels. ${ }^{52}$

\footnotetext{
${ }^{50}$ Shulman, Burning Questions, p. 75.

${ }^{51}$ Normal Mailer raged that Beatnik was "a word coined by an idiot columnist in San Francisco." The term "beatnik" is usually attributed to Herbert Caen, in a 1958 San Francisco Chronicle article printed soon after the launch of the Russian satellite Sputnik. See Lawler, Beat Culture, p. 45; Reilly, The 1960s, 145;Tom Dalzell, Flappers 2 Rappers: American Youth Slang (Springfield, MA: Mirriam-Webster, Inc., 1996), pp. 91-94. Recent claims have been made that African-American Beat writer Bob Kaufman, co-founder, with Ginsberg, of the journal Beatitude, coined the term. See Mona Lisa Saloy, "Black Beats and Black Issues," in Lisa Phillips, ed. Beat Culture and the New America, 1950-1965 (New York: Whitney Museum of Art, 1996), p. 163. Echols uses "Beat" and "beatnik" interchangeably, arguing that to many, they were the same. See Echols, "Hope and Hype in Sixties Haight-Ashbury," footnote, p 224; also, see Echols, Scars of Sweet Paradise: The Life and Times of Janis Joplin (New York: Macmillan, 2000), p. 70.

${ }^{52}$ For a discussion of the major Beats and their influences, see Steven Watson, The Birth of the Beat Generation: Visionaries, Rebels, and Hipsters, 1944-1960 (New York: Pantheon Books, 1995). Several studies exist on the influence of Beat culture in the 1950s and after, including Lisa Phillips, ed. Beat Culture and the New American, 1950-1965; For a look at Beats in Greenwich Village, see Fred W. McDarrah and Gloria S. McDarrah, Beat Generation: Glory Days in
} 
Allen Ginsberg asserted that 'the essence of the phrase 'beat generation' can be found in one of Jack Kerouac's most celebrated phrases, 'Everything belongs to me because I am poor." ${ }^{, 53}$ This fundamental maxim was part of the spontaneous prose added to the original manuscript of the Beat Generation's seminal guide, On the Road, prose that became Visions of Cody, Kerouac's experimental novel, written in 1951-52 (published in 1972). In Visions of Cody, the phrase appears consolatory at first, evoked in the wake of yearning for a beautiful, unattainable girl outside of St. Patrick's Cathedral. According to James Fisher, Kerouac's mission to "sanctify the world" from profane visions through artistic representations places the book's narrator at the cathedral, remarking on his own holy poverty. ${ }^{54}$

"Everything belongs to me because I am poor" was a renunciation of worldly pleasures, which usually included middle-class material trappings. The idea that creative license required a life of spontaneity, necessarily untrammeled by possessions (as well as most interpersonal commitments) ran throughout Beat literature and poetry, which was in turn influenced by Ralph Waldo Emerson, Henry David Thoreau, and Zen Buddhist philosophies. As Beat poet Lew Welch wrote in the 1950s, "Going to Mexico by

Greenwich Village (New York: Schirmer Books, 1996). Lawrence Lipton offers a contemporary fictional account of the Venice Beach Beat scene. See Lipton, The Holy Barbarians (New York: Julian Messner, Inc., 1959); see also John Arthur Maynard, Venice West: The Beat Generation in Southern California (New Brunswick and London: Rutgers University Press, 1991).

${ }^{53}$ Allan Ginsberg, "A Definition of the Beat Generation," in Deliberate Prose: Selected Essays, 1952-1995, Bill Morgan, ed., (New York: HarperCollins, 2000), p. 239; qtd in Susan B.A.

Somers-Willett, Cultural Politics of Slam Poetry: Race, Identity and the Performance of Popular Verse in America (University of Michigan, 2009), p. 56.

${ }^{54}$ Jack Kerouac, Visions of Cody (New York: McGraw-Hill Book Company, 1973), p. 33. Many scholars relate Kerouac's repeatedly asserted asceticism to various spiritual inclinations, including his persistent Catholicism and dabblings in Buddhism. See for example, James Terrence Fisher, The Catholic Counterculture in America, 1933-1962 (Chapel Hill: University of North Carolina Press, 1989), pp. 220-235; Paul Giles, American Catholic Arts and Fiction: Culture, Ideology, Aesthetics (New York: Cambridge University Press, 1992), pp. 411-412; Benedict Giamo, Kerouac, the Word and the Way: Prose Artist as Spiritual Quester (Southern Illinois University, 2000), pp. 46-47. 
motorcycle would be the coolest, but/ Thoreau warns against any undertaking that requires new clothes. ${ }^{, 55}$ Kerouac himself was unsure of what it was he wished to be free and vacillated between a desperate urge to "live, work, and have a family" and a periodic desire to divest himself of those goals and indulge in the madness of his friends. ${ }^{56}$

Admiration of poverty also dovetailed with the Beats' renowned fascination with African Americans. Kerouac recycled "Everything belongs to me because I am poor" in 1959 for a short piece sold to a cheap girlie magazine, Escapade. ${ }^{57}$ "The Beginning of Bop" cast key architects of bop-Dizzy Gillespie, Charlie Parker, and Thelonious Monk - as "12th Century monks high in winter belfries of the Gothic Organ." They waited "like witchdoctors" "miserable cold and broke," saying "Everything belongs to me because I am poor. ${ }^{\Perp 58}$ For Beats, elective poverty was a means of transcendence, and a way of expressing solidarity across the social boundaries of race, class, and spiritual beliefs. The Beat preoccupation with jazz performers and black hipsters articulated the romance of racial outsiderness to mainstream America. In his 1957 essay "The White Negro," Norman Mailer described how white "hipsters" grafted expressions of black experiences onto the suffering of white outsiders. Or as Werner Soller put it, "for the sake

\footnotetext{
${ }^{55}$ Lew Welch, "In Answer to a Question from P.W.," in Lew Welch, Ring of Bone: Collected Poems (San Francisco: City Lights Bookstore, 2013), p. 56. Originally written between 19501960.

${ }^{56}$ In an April 17, 1948, journal entry, Kerouac complained that he can not be himself or accomplish the things he wants while being friends with his current "circle" (including Ginsberg and Burroughs), and ended the entry, "Because I want to live, work, and have a family." See Douglas Brinkley, ed., Windblown World: The Journals of Jack Kerouac, 1947-1954 (New York: Viking, 2004), p. 69.

${ }^{57}$ See Jack Kerouac, “The Beginning of Bop,” in Escapade III (April 1959): 9.

58 "The Beginning of Bop," in Ann Charters, ed., The Portable Jack Kerouac (New York: Viking Penguin, 1995), p. 557.
} 
of convenience, the Bohemian might call 'Negro' everything he thought white America unjustly repressed." 59

Musicians like Dizzy Gillespie directly influenced beat fashion—or more specifically, the aspect of Beat dress that became caricatured as beatnik. Linda Welters attributes at least three elements of beatnik appearance — beret, eyewear, and goatee — to Dizzy Gillespie specifically. Though Gillespie did not use heroin like many jazz musician of the time, he had sensitive eyes due to repeated infections, and wore dark glasses on stage against the glare of stage lights, preferring horn-rimmed glasses for their durability. The goatee reportedly cushioned his mouthpiece and prevented skin irritation. The beret Gillespie picked up from his French travels, adopting the style in 1937, even using the soft hat as a trumpet mute. In adopting these black affectations, middle-class white Americans were following sartorial standards set in Bohemian Paris, filtered through an American jazz sensibility - especially that of be-bop, whose rhythms permeated Beat writing as well. ${ }^{60}$

\footnotetext{
${ }^{59}$ Werner Sollers, Amiri Baraka/LeRoi Jones: The Quest for a "Populist Modernism," (New York City: Columbia University Press, 1978), p. 27; qtd in Somers-Willett, The Cultural Politics of Slam Poetry, p. 55.

${ }^{60}$ See Welters, “The Beat Generation,” pp. 153-154.
} 


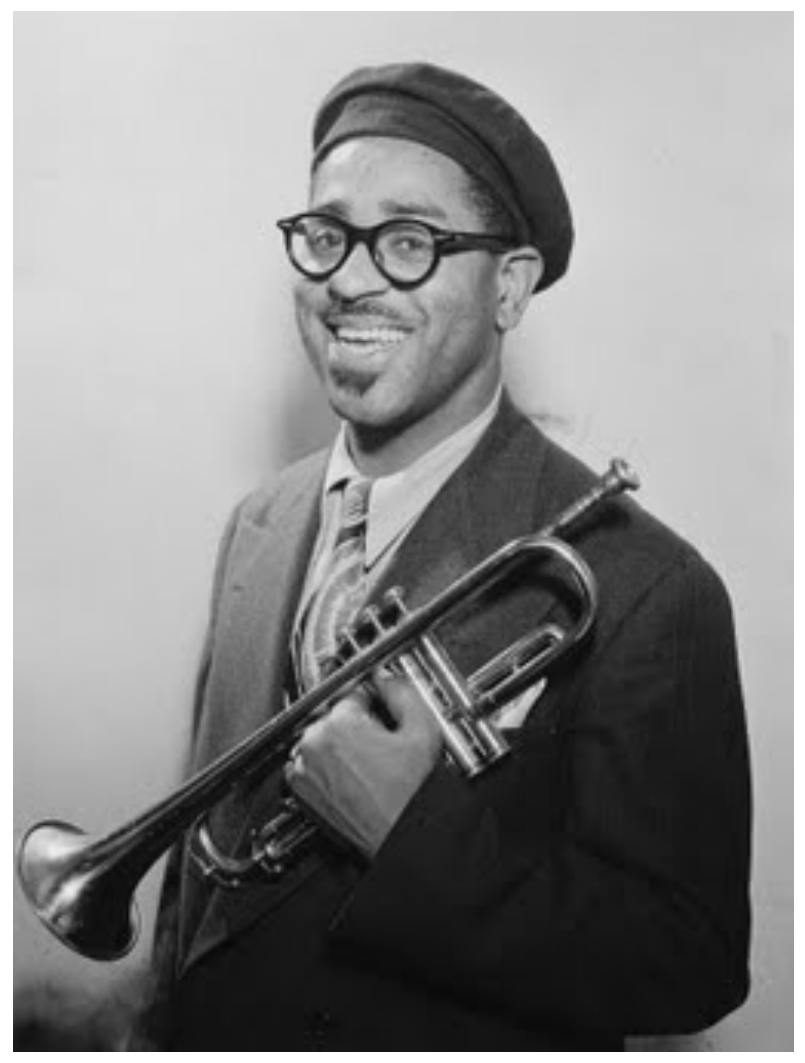

Fig. 4.2. Dizzy Gillespie, circa 1955. William Gottlieb, Library of Congress.

But though some patterns of Beat style emerged over time, neither male nor female Beats displayed the level of black-clad uniformity portrayed by the popular press (and adopted by the young followers who in turn, would rebel against that image by becoming "hippies"). ${ }^{61}$ Before Life, Look, and Time forwarded an image of dark, minimalist disrepair, Beat costumes were not easily defined, aside from a general preference for casual clothing such as chinos, jeans, sweatshirts, tee-shirts, and flannel. Even that tendency, as evidenced by William S. Burroughs' habitual suit, tie, and hat,

${ }^{61}$ Several national magazine articles, beginning in 1958, forwarded an idea of beatniks that covered everything from dress style to sexual proclivities, and shaped much of the public's impressions of Beats. See for example, "Squaresville U.S.A. vs. Beatsville," Life (September 21, 1959): 31-37; and P. O’Neil, "The Only Rebellion Around," Life (November 30, 1959): 114-131. An August, 1959 article, "Real Gone Garb for Fall, Beat But Neat," illustrated the mainstream adaptions of the media's beatnik image. In Life (Aug 3, 1959): 48-49. 
was by no means standard. ${ }^{62}$ The attire worn to Allen Ginsberg's famed reading of "Howl," in October 1955, at Gallery Six in San Francisco illustrated the variety of Beat garb, and also underscored the prevalence of secondhand at the movement's seminal event.

In Michael McClure's account of the gathering, master of ceremonies Kenneth Rexroth presided "elegant in a handsome thriftshop suit," a pin-striped one specially purchased at Goodwill for the occasion. ${ }^{63}$ Ginsberg wore a conservative charcoal gray suit, white shirt, and tie, though Kerouac describes him in Dharma Bums, his 1958 follow-up to On the Road, as one of several "hornrimmed intellectual hepcats with wild black hair." McClure was a "delicate pale handsome poet ...(in a suit)." ${ }^{64}$ Gary Snyder provided the most variety in Kerouac's fictionalized account. Among poets in "various costumes, worn-at-the-sleeves corduroy jackets, scuffly shoes," Snyder's character didn't look like a poet, in "rough workingman's clothes he'd bought secondhand in Goodwill stores. ${ }^{.65}$

Despite the mix of clothing styles, used goods were consistently represented at the reading, which also featured artist Fred Martin's found objects. ${ }^{66}$ Secondhand goods had powerful currency among Beats on both coasts as delegates of delinquency from postwar

\footnotetext{
${ }^{62}$ See Linda Welters, "The Beat Generation," in Linda Welters and Patricia A. Cunningham, Twentieth-Century American Fashion (New York: Berg, 2005), p. 164.

${ }^{63}$ Multiple sources describe Rexroth at this event as wearing secondhand. See for example, Michael McClure, "Painting Beats by Numbers," in The Rolling Stone Book of the Beats (New York: A Rolling Stone Press Book, 1999), p. 35; Barry Miles, Ginsberg: A Biography (New York: Harper Perennial, 1990), p. 195; Another account has Rexroth "[b]ow-tied and wearing a secondhand cutaway coat." See Roy Kotynek and John Cohassey, American Cultural Rebels: Avant-Garde and Bohemian Artists, Writer and Musicians from the 1850s through the 1960s (Jefferson, North Carolina: McFarland \& Company, Inc., 2008), p. 171.

${ }^{64}$ Jack Kerouac, Dharma Bums, (Orig. publ. 1958; New York: Penguin Books, 1976), p. 11; Welters, "The Beat Generation," p. 156.

${ }^{65}$ Kerouac, Dharma Bums, p. 11.

${ }^{66}$ Kotynek and Cohassey, American Cultural Rebels, p. 171.
} 
middle-class proprieties. Whether like Snyder, the used clothes emphasized his

experience camping and working as a logger (rather than his formal Reeds education), or, like Rexroth, thrift shopping produced a parody of an authoritative style of "gangster" rebellion, used goods had powers of nonconformity and reinvention. ${ }^{67}$

Scholars have described the middle-class backgrounds of Beats as formative to their literary and personal style. ${ }^{68}$ They sought stimulation outside the cultures of their upbringing, and looked to view "society from the bottom up, or at least from the outside in." ${ }^{69}$ Beat poet Gregory Corso wrote that "by avoiding society you become separate from society and being separate from society is being beat." ${ }^{, 70}$ Since for many, familiar society was an affluent, consumer-oriented, middle-class one, it would seem that elective poverty (and secondhand) offered entrée into beathood.

But despite his advocacy for elective poverty, Kerouac's own relationship with secondhand was an ambivalent and evolving one. Unlike most other Beats, Kerouac, and even more so, Cassady, were not simply middle class. ${ }^{71}$ Kerouac's parents were French-

${ }^{67}$ Rexroth's suit was also described as a "spiffy gangster-pinstripe suit." See Dennis McNally, Desolate Angel: Jack Kerouac, the Beat Generation, and America (New York: Random House, 1979), p. 203.

${ }^{68}$ See Ann Douglas, "The City Where the Beats were Moved to Howl," in The Rolling Stones Book of the Beats, pp. 3-4.

${ }^{69}$ Christopher Lasch, The New Radicalism in America, 1889-1963: The Intellectual as a Social Type (New York: Knopf, 1965), p. xv, qtd in Robert Allen Skotheim, introduction to Hutchins Hapgood, A Victorian in the Modern World (Seattle and London: University of Washington Press, 1972), p. xix.

${ }^{70}$ Somers-Willett, Cultural Politics of Slam Poetry, pp. 54-55.

${ }^{71}$ Cassady, the Beat most born into down-and-out, did not share other (more affluently raised) Beats' associations of secondhand or "beat" clothing with freedom in his personal reminiscences. After his mother died when he was ten, Cassady grew up with his alcoholic father and divided his adolescence between skid row and reform school. In The First Third Cassady's protagonist wakes next to his father's "drink-swollen face" early in the morning and dons "hated remnants of brother Jimmy's clothes; too-short shoes and knickers which crept above my knees." He walks past "musty-smelling secondhand stores." In order to be romantic, defiant, and liberating elective poverty had to be a choice. See Neal Cassady, "The First Third," excerpt in The Beat Book, pp. 68,71 . 
Canadian and of working-class backgrounds. His father moved to Lowell, Massachusetts—-where Jack and his siblings grew up — to take a job running a small newspaper. Kerouac remained wholly devoted to his mother (whom he often called memere) throughout his 47 years. ${ }^{72}$ His writings depict a struggle between desiring the stability of his mother's care, the discipline of hard work, and the guilt and comfort of his native Catholicism; and the stimulation of wild, drunken, craven ramblings like those in the autobiographical On the Road, which details Kerouac's and Neal Cassady's travels through the United States and Mexico. In the work that would make him famous, Kerouac's fictional stand-in follows the impetuosity of the irrepressible Dean Moriarty (Cassady), the patron saint of irresponsibility. ${ }^{73}$ Antimaterialism is a refrain in On the Road; ownership is a shackle. The hero Moriarty conspicuously eschews ownership, preferring illegitimacy and theft.

Though in On the Road, clothes are approvingly tattered, old, washed-out, cracked, frayed, ragged, baggy, greasy, bug-smeared, torn, belly-hanging, and yes, beat, secondhand is not a theme yet. ${ }^{74}$ Kerouac's romanticization of poverty was partly a defense of what was to him tradition rather than deviance. In Desolation Angels (written in the late 1950s), Kerouac describes the "junks of life" he and his mother pack in preparation for a move from Florida to California. In regarding their piles of "essentials," he recalls the deprivation of the Depression, coloring the material lack with a childish

\footnotetext{
${ }^{72}$ For more on Kerouac's life, see Ellis Amburn, Subterranean Kerouac: The Hidden Life of Jack Kerouac (New York: St. Martin's Press, 1998);

${ }^{73}$ See Jack Kerouac, On the Road (orig. publ. 1957; New York: Penguin Books, 1991).

${ }^{74}$ Descriptions of bedraggled clothing appear throughout the book. See Kerouac, On the Road, pp. 6, 188, 199, 218, 249, 294.
} 
nostalgia for days when "old men with burlap bags at night fished thru garbage cans.",75 But in "1957 prosperous America," people laughed at their junk (which was somewhere in between the standards of the Great Depression and those of the new affluence), much as they laughed as Kerouac's own unfashionable love of his mother and the peace he derived from her passé domestic skills. Kerouac's loving description of memere's mending of his raucously rended clothing, and his admiration of her adeptness of re-use, signals his belief in redemption and in his mother's ability to attain it for him: "A minor cigarette hole in old jeans is suddenly patched with pieces of 1940 jean."76

It is not until Dharma Bums, Kerouac's 1958 follow-up to On the Road, that Kerouac assigns secondhand a meaning beyond sentimentality, one that reflected his (and other Beats') exploration of eastern mysticism, which for a time, funneled Kerouac's attraction to Catholicism into a updated spiritual pursuit. In Dharma Bums, Ray Smith (Kerouac's new fictional foster self) pursues a different role model, one who represents transcendent asceticism and a — at least periodically—-more restrained and studious version of freedom than that of Cassady. Japhy Ryder, modeled after poet Gary Snyder, is a college-educated "Northwest boy" whose "real" education derived from deep in the woods of eastern Oregon. Indian mythology inspired his eventual interest in "the greatest Dharma Bums of them all, the Zen Lunatics of China and Japan."77 Ryder's style signaled an affiliation with the more "natural" pursuits of working-class labor, and his clothes, which served him on his mountain hikes, campfires, and hitchhiking, were

\footnotetext{
${ }^{75}$ Jack Kerouac, Desolation Angels (Orig. publ. 1965, New York: Riverhead Books, 1995), p. 373.

${ }^{76}$ Kerouac, Desolation Angels, pp. 373-374.

${ }^{77}$ Kerouac, Dharma Bums, p. 9.
} 
recycled from the cast-offs of men who actually made livings from logging and construction.

Ryder (Snyder) derived much of his lifestyle ideology from Eastern philosophies and Buddhism, and this proclivity marked the beginning of popular interest in Buddhism in the United States. The "Zen Lunacy" portrayed through Whitman inspired Ryder's prophecy of "a great rucksack revolution," including masses of wandering youth, praying in mountains and refusing to work for the "privilege of consuming., ${ }^{, 78}$ Ryder needs just a rucksack, food, and a good pair of shoes. In fact, he is scared of "all this American wealth.” Despite his Orientalist wisdom and minimalist attitude, Ryder does not represent a wholesale rejection of consumption, but a selective adjustment. Where and how he consumes is as important as how much. Despite his near-phobic avoidance of other retail sites, Ryder scours the thrift shop aisles for old hand-me-downs with a "bemused and happy expression," proving he does derive joy from shopping. ${ }^{79}$

The poetry of Snyder, Ryder's inspiration, reflected his interest in the preservation of the environment, the opposition of a throwaway culture, and the moral superiority of secondhand, foreshadowing the incipient environmental movement, even before the publication of Rachel Carson's The Silent Spring (1962) ${ }^{80}$ His work's natural settings, and advocacy for the human pursuit and preservation of wilderness earned him the label of "ecopoet." In "Bubbs Creek Haircut," mostly penned in 1960, Snyder portrayed secondhand sales venues as not only positive consumer spaces, but as pathways

\footnotetext{
${ }^{78}$ Kerouac, Dharma Bums, p. 97.

${ }^{79}$ Kerouac, Dharma Bums, p.18.

${ }^{80}$ Silent Spring exposed the harmful effects of pesticides on the environment, particularly the avian population, and is often cited as the starting point of the contemporary environmental movement. See Rachel Carson, Silent Spring (orig. publ. in The New Yorker in 1962; New York: Houghton Mifflin, 2002).
} 
on a journey to understanding wilderness. ${ }^{81}$ Before beginning his trek, the narrator gets a haircut and goes to Goodwill to look for a sweater, where he imaginatively animates the "unfixed junk," and demonstrates empathy for the abandoned goods. As the Sierra hike begins, Goodwill reappears in reminiscences as part of a spiritually-invested triumvirate of thrift stores alongside St. Vincent de Paul and Salvation Army, where "A.G. [Allen Ginsberg] and me got winter clothes for nothing." ${ }^{82}$

A ways up the trail, boulders transform into the "sag-asst" chairs of Goodwill, and the question arises of whether the proprietor is "King of Hell" or leader of a paradise of sorts, ruling over objects "freed" from their originally imposed purposes. Throughout the narrator's journey, Goodwill stands in for the attribute. Over the course of an ecospiritual journey, thrift stores became sacred spaces. After ecstatic meditation, the objects in the Goodwill basement become the wild nature: "a room of empty sun or peaks and ridges/beautiful spirits,/rocking lotus throne:/a universe of junk, all left alone." ${ }^{83}$ Garbage becomes something beautiful in its unviability, or through its future potential as something yet unfathomed.

By 1960, when Snyder published "Bubbs Creek Haircut," it seemed to many Beats that their image had been commodified and sullied by an eager press. Once again, Greenwich Village grew wealthier as the media-generated image of the Beat Generation "sold books, sold black turtleneck sweaters and bongos, berets and dark glasses, sold a way of life that seemed like dangerous fun — thus to be either condemned or imitated.

\footnotetext{
${ }^{81}$ Gary Snyder, "Bubbs Creek Haircut," Mountains and Rivers Without End (Berkeley: Counterpoint, 2008), pp. 33-38.

${ }^{82}$ Snyder, "Bubbs Creek Haircut," p. 35.

${ }^{83}$ Snyder, "Bubbs Creek Haircut," p. 36. For further analysis of this "mirror" poem and the role of the past in personal revelations, see Patrick D. Murphy, Understanding Gary Snyder, Columbia, South Carolina: University of South Carolina Press, 1992), pp. 67-70.
} 
Suburban couples could have beatnik parties on Saturday nights and drink too much and fondle each other's wives. ${ }^{94}$ In Burning Questions, it is around this time that aspiring beatnik Zane compromises her own Bohemian ambitions by doing what sociologist Jules Henry described as the female default of the time: "In place of their dreams they take husbands. ${ }^{.85}$

When Zane bows out of Bohemia and marries the "straight" lawyer Ricky, their apartment, "stylish and shabby enough to suit both of us," reflects this compromise. Furnished "half from the street," including "bedraggled finds" like chipped mugs, shadeless lamps and an "ugly old upright piano two men from Good Will" delivered, and "half from the better shops"- - thick Persian rugs and objet d'art, the apartment vexes Zane through the birth of her three children. "[I]t was clear that with lush rugs on the floor and framed pictures on every wall. . I could hardly retain my self-respect." New items served as a "constant reminder of my own impurity." As chagrining as the carpets and prints were, clothing remained key to the sanctity of Zane's bohemian self-image. When Ricky squeezed his twelve suits into their shared closet, "dramatizing our differences with alarming clarity" it was those neatly pressed icons of conformity that would "taunt me with my compromise whenever we made love, reminding me of the fragility of one's image. ${ }^{, 86}$ How could everything be hers if she was no longer poor? For Zane, her secondhand goods were demoted to tokens, representative of her fading past - yet also reminders of the possibility of future rebellion and the refusal to

\footnotetext{
${ }^{84}$ Joyce Johnson, Minor Characters: A Beat Memoir (New York: Penguin Press, 1981), pp. 187188.

${ }^{85}$ Jules Henry, Culture Against Man (New York: Vintage Press, 1963), p. 170; qtd in Wini Breines, Young, White, and Miserable: Growing Up Female in the Fifties (Chicago: University of Chicago Press, 1992), p. 35.

${ }^{86}$ Shulman, Burning Questions, pp. 143-144.
} 
succumb, to "sell-out," along with her continued residency in the Village (rather than a suburb) and the claim that "the so-called benefits" of her marriage felt like personal liabilities. ${ }^{87}$ Secondhand persisted as a symbol of Bohemian lifestyle — but it adapted to new aesthetics and new ideals. Wealth changed the character of the Village in the late 1950s. According to Joyce Johnson, the autumn of 1957 marked the moment when Village painters began to make money and "turn up self-consciously in stiff new brown corduroy suits." Some of the "old ladies" in the area retaliated to both the media stereotypes and new money "by picking up the wilder stuff in thrift shops — Spanish combs and beaded dresses from the twenties that ripped under the arms if danced in too energetically. They draped themselves in embroidered piano shawls, put on purple mesh stockings, and called themselves Beat Pre-Raphaelites." ${ }^{88}$ In other words, beatniks began to look like hippies.

\section{“I always longed not to be contained within my class."-Jane Ormsby-Gore}

As "Beat Pre-Raphaelites" reworked their Bohemian image with the help of used goods, another positive association of secondhand among educated, affluent youth was in the works - years before "hippie" was a word with public meaning. In the 1950s, some discarded clothing advanced from being undesirable trash into collectible commodities. Much as junk shops became thrift stores, and curiosity shops morphed into antiques stores, "old" was promoted to "vintage."

After the end of the war, society pages often reported in detail on club-sponsored rummage sales and benefit sales and fashion shows featuring secondhand goods,

\footnotetext{
${ }^{87}$ Shulman, Burning Questions, p. 144.

${ }^{88}$ Johnson, Minor Characters, p. 210.
} 
including clothing descriptions specifying production date or "vintage," a designation used by serious dealers of all collectible objects. Specifying the date (vintage) of items showed specialized knowledge and elevated rummage sale goods to a higher status. The word vintage originally pertained only to winemaking, including the process of harvesting and fermenting. A "vintage wine" denoted one whose grapes were all from a single specified year; vintage also indicated highest quality and best year for certain wines. Commonly, vintage became understood (incorrectly) to indicate particularly old or excellent wine for all varietals. ${ }^{89}$ It was not until the late 1920s, when collecting furniture and automobiles became hot hobbies that "vintage" was applied outside of enology, sometimes in conjunction with a specific year, and sometimes just utilizing the wine-born connotation of quality and age. ${ }^{90}$ The designation worked its way slowly into association with clothing in the 1950s, first by specifying year: "smart ensembles of 1895 vintage" or "a slinky satin and beaded evening dress of 1926 vintage." $" 91$ Over the course of dutiful reportage on postwar benefit events, the word migrated to the adjectival form in instances when precise clothing genealogy was unknown or when referring to an aggregate wardrobe. For example, at a 1954 Town and Country suburban fashion show, the Batavia Woman's club members modeled "[v]intage gowns." ${ }^{, 92}$ Mid-1950s' journalists put the adjective in quotations (one fashion show included ten “"vintage' gowns”) suggesting

\footnotetext{
${ }^{89}$ For a history of "vintage wines," see P.T.H. Unwin, Wine and the Vine (New York: Routledge, 1996), p. 13.

${ }^{90}$ The Oxford English Dictionary online indicates a 1928 mention of a "vintage Buick" as the first such usage. "Vintage," n, trans. OED Online (Oxford University Press, May 18, 2013), http://www.oed.com/view/Entry/223593?isAdvanced=false\&result=1\&rskey=zOg4Z2\&\#content Wrapper.

${ }^{91}$ See Judith Cass, "Fashion and Fancy," Chicago Daily Tribune 30 Sep 1945, p. E1; Peggy Preston, "Congressional Club Members Delve in Old Trunks for Frocks," The Washington Post, 19 Feb 1948, p. B7.

92 "Batavia Group to Wear Town, Suburb Styles," Chicago Daily Tribune 10 Oct 1954, p. W7.
} 
novel usage. ${ }^{93}$ The more frequent application of vintage to modify descriptions of clothing indicated that those materials were becoming objects worthy of collecting, like Model Ts and colonial grandfather clocks.

The modifier stuck with the "vintage raccoon craze" of 1956-57, "one of the zaniest college fads since the goldfish-gulping era." ${ }^{" 94}$ The revival of the coonskin coat fashion among the collegiate crowds purportedly began with an entrepreneurial Greenwich Village couple. At a party in their Village apartment, Sue Salzman recounted a near grappling match between herself and another Salvation Army patron over a "true raccoon" coat she wanted on a whim. After everyone agreed it would have been an excellent score, an attendee reassured the disappointed thrift-shopper with the promise of a grand supply from a relative's boys' clothing business. The retailer happened to have a warehouse full of the old coats from when the original collegiate trend of 1929 abruptly ended alongside national confidence in stock market stability. After witnessing broad enthusiasm for the furs, the Salzmans decided to go into business. ${ }^{95}$

Before long, Glamour magazine published a photo of a coonskin coat and named the Salzmans as suppliers. The Salzmans received hundreds of letters and phone calls, including an urgent request from Lord \& Taylor, a leading collegiate stylist of the time. Next, Lord \& Taylor advertised "vintage raccoon coats" in a promised "state of magnificent disrepair." College students embraced the idea en masse, and department stores nationwide quickly exhausted any of their own supplies and acquired outside

\footnotetext{
${ }^{93}$ Louise Hutchinson, "First Ladies Feted; View Fashion Show," Chicago Daily Tribune 11 Aug 1955, p. C6; See "Racoon Swoon in New Flurry," Life (Sept 9, 1957): 83.

${ }^{94}$ Nan Robertson, "Fad Creates Big Tycoons in Racoons," New York Times 15 Aug 1957, p. 15; see also, New Yorker (Aug 15, 1957).

${ }^{95}$ See "Undergraduate Elegance," Gentry (Fall 1956): 100.
} 
dealers. Advertisements promised looks that were "down-at-the-heel," "shabbily genteel," full of "lovely holes," and achieved a "snobby seediness.",96

The coonskin coat trend of 1956-1957 illustrates how secondhand fads could travel both inside and outside of major fashion corridors. From a hip Village flat to those "in the know" to a major fashion magazine to an influential department store to college dorms, the furry fad gained momentum. The Salzmans weren't selling out. They were simply selling. As for the buyers-well, the nostalgia for the excess of the 1920s on the part of young, affluent college students full of a sense of their own possibilities was more narcissistic than escapist. "True raccoons" were 1920s models, and the old coats were part of a popular fascination with the era (newer versions failed to catch on). According to Mr. Salzman, the coats appealed to "lovers of the Lost Generation, sports car enthusiasts, lady fashion magazine editors and high fashion models." The Salzmans fueled the furs' romantic images by reporting that "in one coat, they found a revolver and a mask; in another, a list of speakeasies.. ${ }^{97}$ This secondhand trend referenced opulence instead of poverty, excess over thrift. The Great Gatsby-themed fraternity soirees are easy to picture.

The popularity of used clothes continued to accelerate throughout the 1960s. However, the involvement of department stores diminished over time, probably in part because stores exhausted their own warehouses of old goods through auctions and divestment sales. Once the desired items re-circulated, anyone might buy and sell. The

\footnotetext{
${ }^{96}$ See "Raccoon Swoon in New Flurry," Life (Sept 9, 1957): 83; Deirdre Clemente, in studying collegiate fashions, points out that the original style associated with the first raccoon coat trend bears relevance to 1960 s fashion, noting that "the 'sloppy joe' sweaters and unkempt saddle shoes of the 1930s were the predecessors of the tie-dye t-shirts and bare feet of the 1960s." See Clemente, "The Collegiate Style: Campus Life and the Transformation of the Collegiate Wardrobe, 1900-1960" (dissertation, Carnegie-Mellon University, 2010), p. 8.

${ }^{97}$ Robertson, "Fad Creates Big Tycoons," p. 15.
} 
secondhand market, while subject to many of the determining factors of firsthand fashions, was not easily controlled by the fashion industry "Vatican." Neither, however, was 1960s "hippie" fashion simply a reaction to mainstream style in the hopes of creating a classless society.

"Ragamuffin chic" did not simply arise from the frustrations of the masses, but relied in part on the influences of individuals - like London socialite Jane Ormsby-Gore, San Franciscan musician George Hunter, and Haight-Ashbury fashion designer Linda Gravenites. In fashion as in music, the "British invasion" of the 1960s influenced American culture substantially, but the tide flowed both ways. ${ }^{98}$ Competition and interchange between London and San Francisco fine-tuned the secondhand style associated with "hippies." In 1965 and 1966, "London was cannibalizing and fragmenting ancient couture found at antique stalls; San Francisco was discovering humbler specimens of handwork at the Goodwill thrift shops and becoming engrossed in the lore of the frontier West and the American Indian." 99

In London, celebrated members of Great Britain's upper class endorsed the craze for old clothes. Jane Ormsby-Gore, daughter of the British Ambassador to the U. S. during Kennedy's presidency, and reputed inspiration for the Rolling Stones song "Lady Jane," advertised a style that typified and promoted the proto-hippie look of the early-tomid sixties: high fashion mixed with rare secondhand pieces like embroidered Russian boots, feathers, and other fantastic items, many that she embellished or combined herself,

\footnotetext{
${ }^{98}$ See Barry Miles, The British Invasion: The Music, The Times, The Era (New York: Sterling Publishing, 2009).

${ }^{99}$ Lobenthal, Radical Rags, p. 109.
} 
to gypsy-like effect. ${ }^{100}$ Ormsby-Gore was a public figure in the fashion world, and never masked her preference for cast-off clothing, not even when drafted to serve on staff at British Vogue. She claimed her motivation for eclecticism was natural at a time when “everything was being broken down," especially "social strata." In retrospect, the heir to nobility insisted, "I always longed not to be contained within my class."

When examined, though, the very particular old clothes in which she dressed herself signaled membership in a very privileged class (Ormsby-Gore was born into a titled Welsh family). ${ }^{102}$ According to Vogue's 1966 article on her, her wardrobe reflected nothing more than a "detestation of all things commonplace." ${ }^{\text {"103 }}$ While some of her clothing hailed from the open-air stalls of Portobello Road, which Life called that same year "no fashion center but a flea market of some twenty years standing," many of her other clothes were made by high-end dressmakers. ${ }^{104}$ Vogue ended their article by describing Ormsby-Gore as "a medieval monarch surrounded by her courtiers," hardly the image of a classless revolutionary. ${ }^{105}$

Ormsby-Gore's outfit (Figure 4.3) indicated knowledge of modern fashion history and a creative eclecticism. Details of her costuming also suggested affluence. The striped, Portobello-Road coat is by Paul Poiret, an early twentieth-century fashion innovator

${ }^{100}$ Rob Young, Electric Eden: Unearthing Britain's Visionary Music (New York: Faber and Faber, Inc., 2010), pp. 295-296; Cally Blackman, "Clothing the Cosmic Counterculture: Fashion and Psychedelia," in Cristoph Grunenberg and Jonathan Harris, eds., Summer of Love:

Psychedelic Art, Social Crisis and Counterculture in the 1960s (Liverpool: Liverpool University Press, 2005), p. 215.

${ }^{101}$ Lobenthal, Radical Rags, pp. 34-35.

${ }^{102}$ See Anneli Rufus and Kristan Lawson, The Scavengers' Manifesto (New York: Penguin, 2009), pp. 125-127. For more on Ormsby-Gore and her fashion influence, see also Young, Electric Eden, pp. 296-307.

${ }^{103}$ Christopher Gibbs, “Jane Ormsby-Gore: Fashion Original,” Vogue, U.K. (January1966).

${ }^{104}$ Life noted in December 1966, "English youth is deserting Carnaby Street in favor of Portobello Road." See "In London, Old Clothes are the Latest Noise," Life (Dec. 2, 1966): 85; Gibbs, "Jane Ormsby-Gore."

${ }^{105}$ Gibbs, "Jane Ormsby-Gore." 
perhaps best known for his disregard of feminine structure garments like corsets, the influence of Islamic Orientalism (as seen in his popular "harem" pants), and generous draping. Renowned before World War I, Poiret died in 1944 poor and forgotten; interest in his designs was, in 1966, only recently revived, along with those of his friend, Elsa Shiaparelli. ${ }^{106}$ Ormsby-Gore's choice showed esoteric knowledge of very recent fashion trends (and her own influence on them). The Edwardian motoring hat belonged to her great-grandmother and was a rare piece from the advent of automobiles and bespoke of a familial lineage that participated in new technology at its outset. Ormsby-Gore found the handmade cream silk shirt at a trip to Paris's marché aux puces —a regular shopping sojourn that, once again, indicated wealth and leisure. The outfit is finished off with a military belt from late $18^{\text {th }}$ century, the sort of touch that would become invested with strong parodic protest by American Vietnam War protesters—but not before rockstars Eric Clapton, John Lennon, Mick Jagger, and Jimi Hendrix all performed and posed in military jackets, many reportedly purchased at one of London's first secondhand boutiques, I Was Lord Kitchener's Valet (opened in 1964). ${ }^{107}$

\footnotetext{
${ }^{106}$ For more on Paul Poiret, see Alice Mackrell, Paul Poiret (New York: Holmes and Meier, 1990); For more on the influence of Islamic Orientalism in Poiret's and others' designs, see Valerie Steele, The Berg Companion to Fashion (New York: Berg, 2010), p. 196.

${ }^{107}$ I Was Lord Kitchener's Valet (IWLKV) was reportedly not very busy until 1966, when rock stars began to frequent it. In 1966, Mick Jagger appeared on television wearing a "red Grenadier guardsman dummer's jacket" purchased at IWLKV, and the store was swarmed. See Rufus and Lawson, The Scavengers' Manifesto, pp. 125-127; and interviews with Jane Ormsby-Gore, conducted for the Victoria \& Albert Museum. http://www.vam.ac.uk/content/articles/i/janeormsby-gore/ Accessed June 20, 2013.
} 


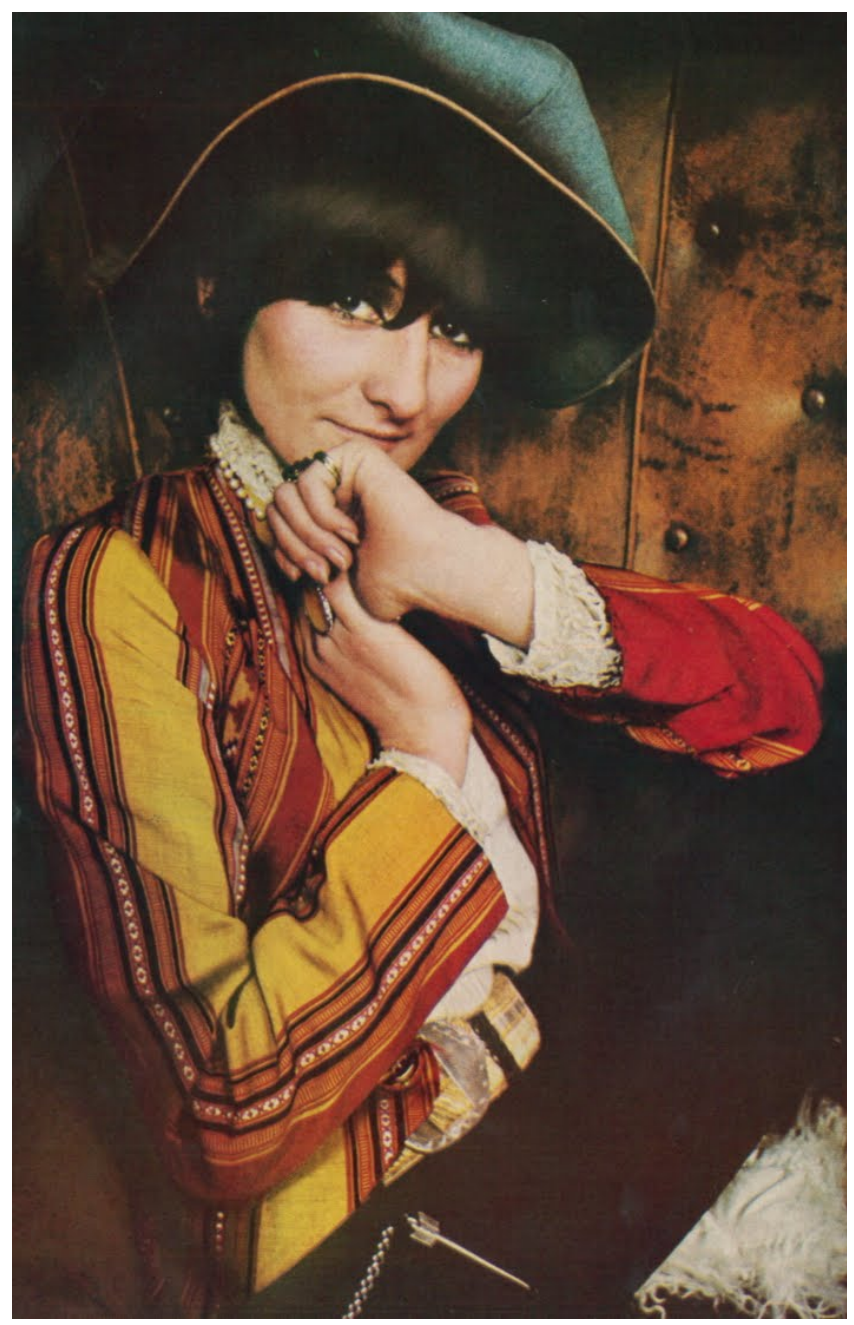

Fig. 4.3. Jane Ormsby-Gore from $U K$ Vogue, January, 1966.

Ormsby-Gore's claims of class indifference were belied by the details of her clothingand the time required to find and compose the outfits. Bohemian elective poverty often depended on some clue that the apparent destitution was voluntary—even Japhy Ryder had "mountain-climbing boots, expensive ones, his pride and joy, Italian made."108

Zane, an observer of and peripheral participant in Greenwich Village Bohemia for years before she found her own rebellion, repeatedly emphasizes the centrality of an

\footnotetext{
${ }^{108}$ Kerouac, Dharma Bums, p. 11. In fact, a "touch" of richer apparel became part of instructions for doing the "poor" look chicly. In a 1975 guide book to "cheap chic," the authors mention that "[i]f you look closely at a woman with a strong individual style, you will discover there is almost always something in her outfit that costs a lot." See Caterine Milinaire and Carol Troy, Cheap Chic (New York City: Harmony Books, 1975), p. 37.
} 
elective (and selective) poverty to her own identity as a "rebel." In doing so, she describes deviation that marks poverty displays as voluntary. For example, on the cusp of her first affair with a woman, a consummation of her feminism and her own hard-won self-love, Zane pauses to assess the setting, finding her soon-to-be lover's home décor consistent with that of "the sordid romances" of her beatnik youth:

Lumpy mattress on the floor beside a whitewashed brick wall in the upper reaches of a heatless walkup. Posters on the wall in place of prints, cheap California wine, marijuana, stacks of precious books, and even an expensive hi-fi (the one invariable luxury marking the poverty as partly voluntary, decade after decade). ${ }^{109}$

After all, if elective poverty were a total guise, it would become unrecognizable as a choice and cease to have social or political significance. But sometimes, the suggestion that secondhand was an alliance with working classes was purely symbolic. Socialites like Ormsby-Gore provided the clientele for London boutiques like I Was Lord Kitcherner's Valet and Granny Takes a Trip (both opened early in 1966), which supplied wealthy bohemians with Victorian undergarments, 1920s flapper dresses, exotic accents like Arab headdresses, military uniforms like those worn by the Beatles and Jimi Hendrix, and 1930s Chicago gangster suits. The prices soared far beyond those of the Salvation Army. ${ }^{110}$ By 1967, everyone in London was discovering forgotten caches of old clothes. Large department stores threw huge divestment auctions, digging into stores of unsold stock. Heirs dug heavy trunks out of cold storage, revealing dead marchionesses' gowns, and amateur playhouses marketed hoards of century-old clothing. Sotheby's auctioned a rediscovered stockpile of ballet costumes from the founder of the Ballets

\footnotetext{
${ }^{109}$ Shulman, Burning Questions, p. 280.

${ }^{110}$ Blackman, "Clothing the Cosmic Counterculture," p. 215; Rufus and Lawson, The Scavengers' Manifesto, p. 127.
} 
Russes - the design of which had, incidentally, strongly influenced Paul Poiret's popular 1920s designs. ${ }^{111}$ Vintage clothing had arrived.

The bricollage style quickly became closely associated with a new youth culture appellation: hippie. Despite the mutual antagonism between "beatniks" and "hippies," there was considerable continuity between the bohemianism of Beats and hippies on both coasts of the United States. The use of the word "hippie" to apply to the new generation of beatniks emerged from derisive Beat writings like Kenneth Rexroth's 1961 short essay disparaging Beat habits of "crow-jimism," as he and others referred to the white mimicry of an unrealistic fantasy of African-American experiences. ${ }^{112}$ On Sept. 5, 1965, journalist Michael Fallon wrote about the Blue Unicorn coffeehouse in Haight-Ashbury, referring to it as a "new haven" for a generation of beatniks moving into the area from North Beach: hippies (who, incidentally, could browse the free secondhand clothing boxes there, taking what they needed). ${ }^{113}$ Older Beats adopted "hippie" as a term of derision, employing the diminutive to suggest hipsters who did not quite get it. ${ }^{114}$ "Hippie" was

\footnotetext{
${ }^{111}$ Lobenthal, Radical Rags, p. 39. For more on Poiret's aesthetic influences, including the Ballet Russes, see Mary E. Davis, Classic Chic: Music, Fashion, and Modernism (Berkeley: University of California Press, 2006), pp. 22-47.

${ }^{112}$ See George Mandel, Flee the Angry Strangers (New York: Thunder's Mouth Press, 1952), p. 385; Bradford Morrow, ed., World Outside the Window: The Collected Essays of Kenneth Rexroth (New York: New Directions Books, 1987, originally published 1961), pp. 191-196. Some sources suggest an even older etymology, originating among black hipsters in the 1940s. In his 1964 memoir about 1940s Harlem, Malcolm X recalls "hippy" as a word African Americans used to describe white men who "acted more Negro than Negroes." See Malcolm X and Alex Haley, The Autobiography of Malcolm X (Ballantine Books, 1999), p. 97, qtd in Scott Saul, Freedom Is, Freedom Ain't: Jazz and the Making of the Sixties (Boston: Harvard University Press, 2009), p. 86.

${ }^{113}$ Robert C. Fuller, Stairways to Heaven: Drugs in American Religious History (Boulder, Colorado: Westview Press, 2000), p. 80.

${ }^{114}$ Mark Matthews, Droppers: America's First Hippie Commune, Drop City (Norman, Oklahoma: University of Oklahoma Press, 2010), pp. 77-78.
} 
probably not widespread until Herb Caen, the San Francisco journalist usually credited with coining "beatnik," began to use it in $1967 .{ }^{115}$

By the time the "hippie" came to national attention in the mid-to-late 1960s, the perception of Beat identity and style was long saturated with media sensationalism, obscuring the movement's original heterogeneity. ${ }^{116}$ The hippie enclaves in Greenwich Village and San Francisco were established by young wanna-be Beats, some of whom found the Beat fashions and attitudes uninviting_ “ “introverted and depressed: black poetry and black clothes." ${ }^{117}$ The hippie community of Haight-Ashbury owed its existence to the Beat enclave in North Beach. As North Beach succumbed to the commercial appropriation that drove cost of living up, many of the dispossessed moved to the area around the intersection Haight and Ashbury streets where they rented cheap Victorian houses. ${ }^{118}$

While North Beach beatnik life lured hippies to the proximity of Haight-Ashbury, others claim that the San Francisco scene actually began about four hours away in the renovated ghost town of Virginia City, Nevada. About a hundred years before, Virginia City was the center of the Comstock Lode silver rush and a hub of the Wild West prospector life. In 1965, Virginia City became hailed headquarters of the new Wild West,

\footnotetext{
${ }^{115}$ See for example, "Take a Hippie to Lunch Today," San Francisco Chronicle 20 Jan1967, p. 37. Peter Coyote accused Time magazine of coining "hippie" in order to trivialize "those seeking alternatives to Time's official reality. See Coyote, Sleeping Where I Fall: a Chronicle, (Washington D.C.: Counterpoint, 1998) p. 76.

${ }^{116}$ Maynard, Venice West, pp. 13-14, 17-20; citing Francis J. Rigney and L. Douglas Smith, The Real Bohemia (New York: Basic Books, 1961).

117 These remarks stem from Margaret Nofziger, who spent time among the Beat enclaves of Venice Beach and San Francisco before moving to Haight-Ashbury and adopting a more colorful style. See Margaret Gaskin [Nofziger], interview with Leonard Wolf, n.d., in Wolf, Love Generation, p. 85, qtd in Tim Hodgdon, Manhood in the Age of Aquarius: Masculinity in Two Countercultural Communities, 1965-83 (New York: Columbia University Press, 2007), p. 98 ${ }^{118}$ Charles Perry, The Haight-Ashbury: A History (New York: Random House, 1984), p. xiv; Lobenthal, Radical Rags, p. 31.
} 
when a couple of entrepreneurs moved in and restored a large Victorian house, complete with bat-wing doors and a shaded wooden sidewalk. They named it the Red Dog Saloon, a common name for saloons in the 1860s. The last element for this outlaw-themed psychedelic bar was a new band, The Charlatans, organized and designed by George Hunter, a student at San Francisco State. ${ }^{119}$

Like many future Haight-Ashbury residents, Hunter originally moved to San Francisco hoping "to be part of the Beat Generation," only to find the scene abandoned. ${ }^{120}$ Hunter soon moved to the Haight, where he spent hours perusing the many area thrift stores in order to fine-tune his and his bandmates' look. ${ }^{121}$ Openly more style than substance, The Charlatans had reportedly never played until their audition at The Red Dog Saloon, but their cracked cowboy boots, wasp-waisted coats, and straw boaters or cowboy hats were a perfect match for the Red Dog Saloon's velvet curtains, crystal chandeliers, and antique bar. ${ }^{122}$

The Charlatans are often credited with pioneering acid rock, incorporating light shows, and creating the first psychedelic art poster. Along with Ken Kesey and his Merry Pranksters, The Charlatans performances in Virginia City galvanized the hippie

\footnotetext{
${ }^{119}$ For more on Hunter and The Charlatans, see Carol Brightman, Sweet Chaos: The Grateful Dead's American Adventure (New York: Pocket Books, 1998); pp. 92-94; Barry Miles, Hippie, (New York: Sterling Publishing Company, 2005), pp.28-30.

${ }^{120}$ Ellis Amburn, Pearl: The Obsessions and Passions of Janis Joplin ( New York: Warner Books, 1992), p. 50; Echols, Sweet Scars of Paradise, p. 171.

${ }^{121}$ John Bevus Reid and Ronal Michael James, eds., Uncovering Nevada's Past: A Primary Source History of the Silver State (Reno: University of Nevada Press, 2004), p. 201.

${ }^{122}$ Hunter turned down Janis Joplin for the band, saying she did not look that part, and later remarked, "I still feel really stupid for having been so oblivious," from an interview with Alice Echols, qtd in Echols, Scars of Sweet Paradise, p. 84. The Red Dog Saloon was central to the development of San Francisco's music scene in numerous ways, giving several psychedelic bands their early gigs and attracting luminaries of the countercultural scene. See Reid and James, Uncovering Nevada's Past, pp. 200-202; See also Miles, Hippie, p. 30.
} 
community in the summer of $1965 .{ }^{123}$ Hunter infused both hippie fashion and the style of publicity graphics with a Victorian flair - the latter especially owing to his admiration for artist Maxfield Parrish. ${ }^{124}$ Hunter relied on thrift store finds to distinguish The Charlatans' look from London's "mod fashion," which embraced the brief skirts and smooth, tailored lines of Mary Quaint. Mod, shorthand for modernists, described the style of jazz musicians and enthusiasts. Rock critic and sociomusicologist Simon Frith traces mod culture back to beatnik coffeehouses, calling mods "clothes-conscious children of Jewish rag trade families" who met up with semi-beatniks in London's Soho coffeeshops — which sounds quite like Second Hand Rose. ${ }^{125}$

\footnotetext{
${ }^{123}$ The best account of the Merry Pranksters remains to be that by Tom Wolfe, The Electric KoolAid Acid Test (New York City: Farrar, Straus and Giroux, 1967). For more on the genesis of psychedelic concerts and the "symbiosis between music and art,"see Sally Tomlinson, "Psychedelic Rock Poster: History, Ideas, and Art," in Ann Charters, ed., The Portable Sixties Reader (New York City: Penguin Books, 2003), pp. 291-305.

${ }^{124}$ See Dayton Lummis, Clippings from the Vine: Selections from the Public Works of Dayton Lummis (Bloomington, Indiana, 2009), pp. 162-163; Brightman, Sweet Chaos, pp. 92-94.

${ }^{125}$ See Dick Hebdige, "The Meaning of Mod," in Stuart Hall and Tony Jefferson, eds., Resistance Through Rituals: Youth Subcultures in Post-War Britain (London: Routledge, 1993); Simon Frith, Sound Effects: Youth, Leisure, and the Politics of Rock 'n' Roll (New York: Pantheon, 1981), p. 220.
} 


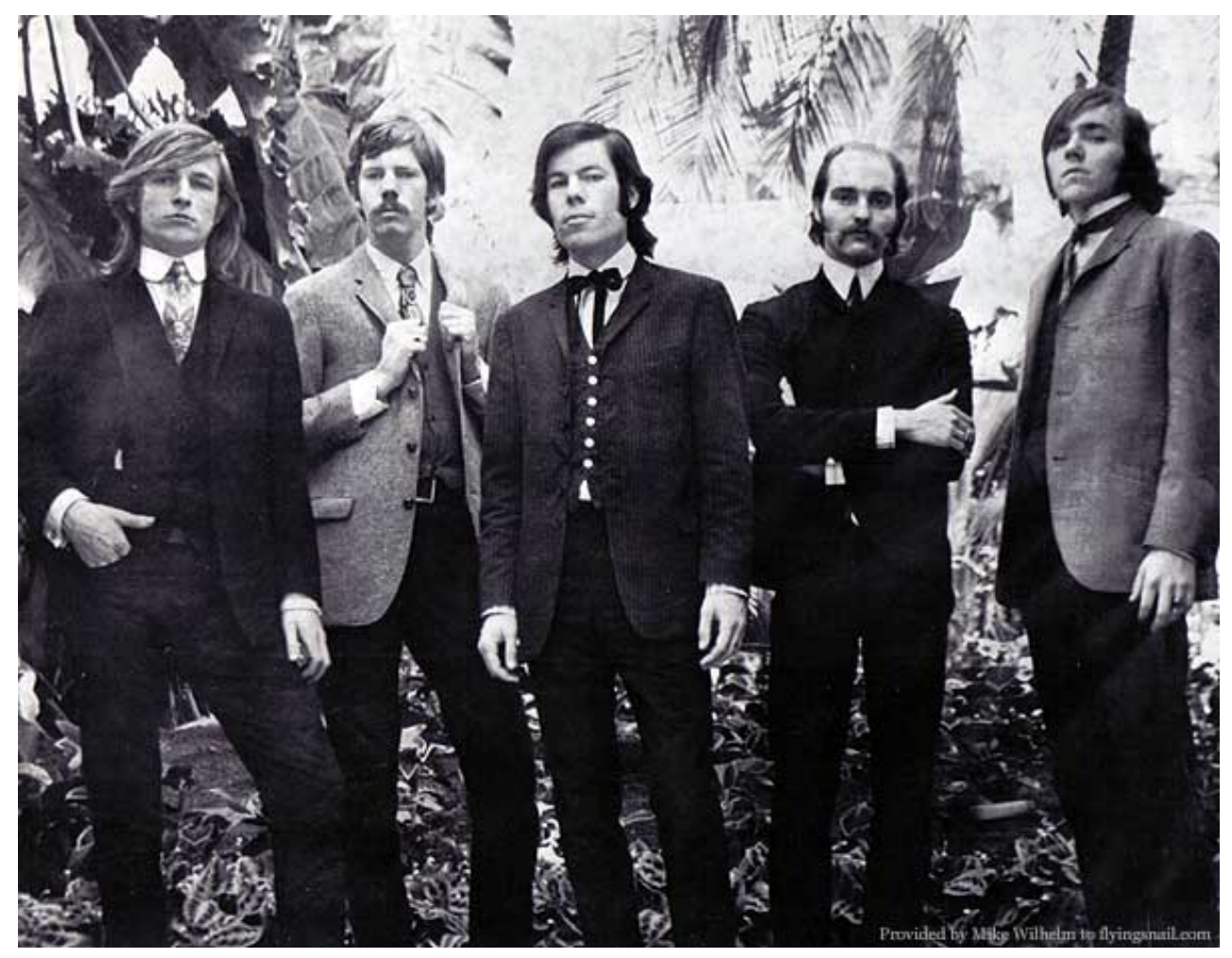

Fig. 4.4. The Charlatans, 1964. Publicity photo, provided by Mike Wilhelm.

The choice of Old West fashion in 1960s California as a counter to the British Mod look was a solid publicity choice. Baby boomers, reared on the fantasy of the Hollywood western film, were expert readers of the style. The posited ideals of the frontier West, as described in lore and monumentalized on the silver screen, included individualism, self-reliance, a relatively unspecific idea of progress (whether political, technological, communal), and the success of the democratic process. The bolo ties, handlebar mustaches, belt buckles, and accompanying swagger, were part of a solidly and singularly American myth. ${ }^{126}$ In Figure 4.4, a publicity photo from 1964 (before the band

\footnotetext{
${ }^{126}$ As David Hamilton Murdoch asserts, "[n]o other nation has taken a time and place from its past and produced a construct of the imagination equal to America's creation of the West." See Murdoch, The American West: The Invention of a Myth (Reno: University of Nevada Press, 2001), p. vii. The Wild West was a trope of popular cultural forms since the 1860s. Christine Bold writes about popular western fiction in Selling the Wild West: Popular Western Fiction, 1860 to 1960 (Bloomington and Indianapolis: Indiana University Press, 1987). Michael L.
} 
had ever played in public), The Charlatans' pose communicates individualism. They do not touch each other. For everyone but Mike Wilhelm, in the center, posture and hand placement suggests self-protectiveness. Mike Wilhelm's hands dangle at his side, but with his level stare and slightly curved fingers, he looks ready to draw a six-shooter from his holster. The picture is a showdown.

The Charlatans may have been the first to set the tone for image-conscious psychedelic bands, but fashion designer Linda Gravenites, the adopted daughter of wealthy Los Angeles Republicans, refined the psychedelic dress styles of hip San Franciscans in the mid-to-late 1960s, by rigging up bellbottoms from old slacks or skirts, embroidering on everything, and re-purposing Victorian lace and velvet - mixed with new synthetics. After getting kicked out of Whittier College, Gravenites moved to North Beach in 1959 but quickly saw the beat movement lose its literary and artistic focus and decline, according to her, into "a subculture revolving around speed." In a few years, she followed other disappointed would-be beatniks to the Haight-Ashbury neighborhoodwhere she met Janis Joplin, for whom she designed stage costumes, including Joplin's much-touted Woodstock outfit, lace slacks and tunic from fabric cannibalized from a secondhand tablecloth (fig. 4.5). ${ }^{127}$

Johnson discusses the extension of the idea of the West-including clothing — into contemporary American culture in The Westers: The West in Contemporary American Culture (Lawrence, KS: University of Kansas Press, 1996).

${ }^{127}$ Echols, Scars of Sweet Paradise, pp. 70-73; Lobenthal, Radical Rags, p. 111. 


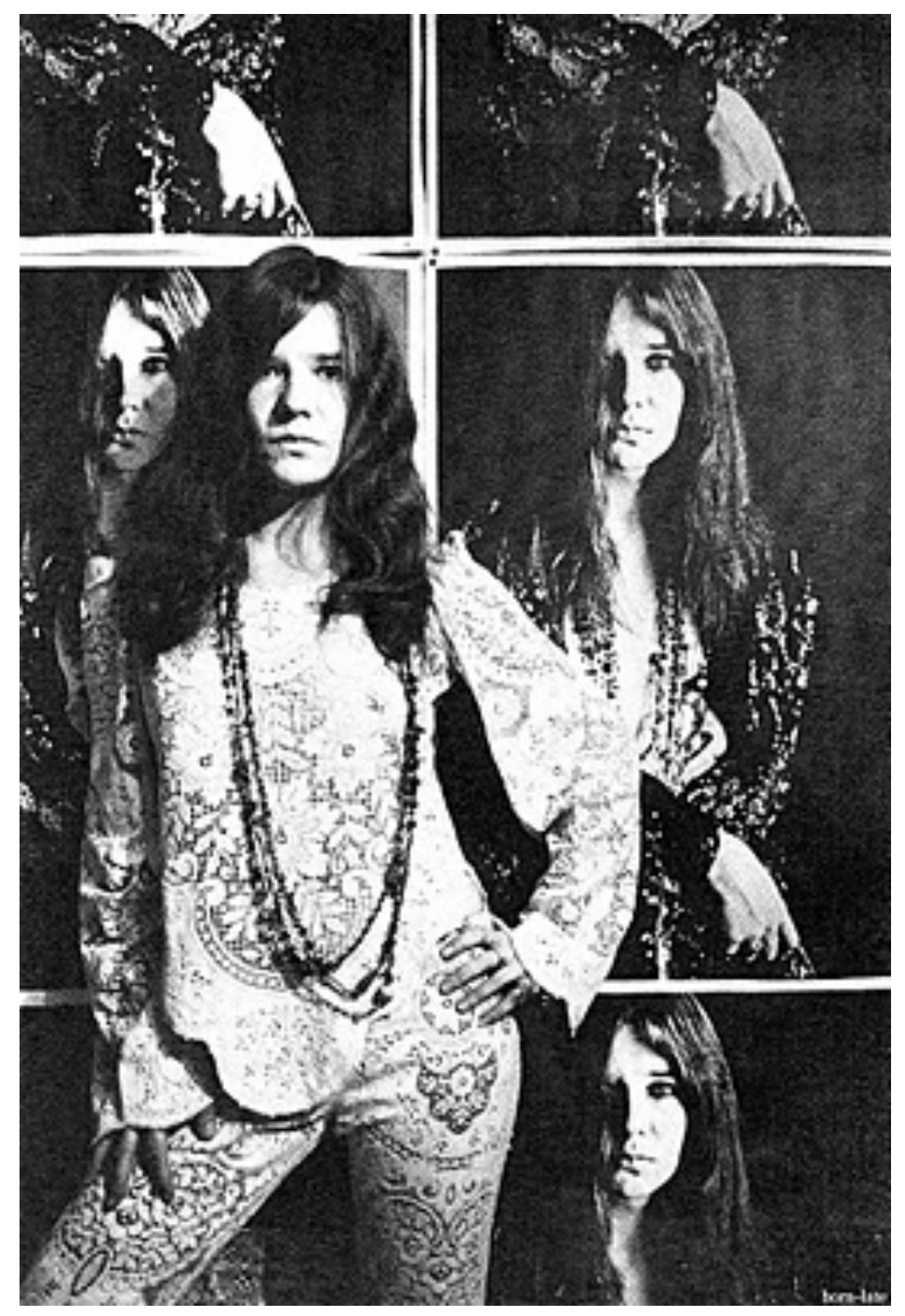

Fig. 4.5. Janis Joplin in a Linda Gravenites tunic and pants, remade from a secondhand lace tablecloth in 1967. From Radical Rags, p. 111.

Gravenites' wide-ranging aesthetic arose as a part of her disenchantment with the beatnik ideal, which she dismissed as "a rejection of all worldly values — including beauty." According to her, "North Beach was a study in black and white; the HaightAshbury is a crazy quilt of living color." ${ }^{128}$ Gravenites sold some of her creations at local boutiques, but mostly, she created outfits on order, catering to individual whims. Los Angeles competed with San Francisco for West Coast style innovation, but Gravenites dismissed her home city's boutique clothing scene by saying "Los Angeles was where

${ }^{128}$ Lobenthal, Radical Rags, pp. 112-114. 
you went to shop at stores that sold clothes" whereas in San Francisco, "you went to the Goodwill, or made it yourself or had a friend who did.",129

On October 16, 1965, the nascent hippie community strutted and preened in front of each other at the dance held by the Family Dog commune at Longshoremen's Hall. The clothes were resplendent and various, from Allan Ginsberg, quietly clad in the white hospital orderly outfit he had affected since his return from India, to the younger Bohemians, "in Mod clothes, Victorian suits, and granny gowns, Old West outfits, pirate costumes, free-form costumes. ${ }^{, 130}$ Like Ormsby-Gore's more outlandish gear, the impracticality of these costumes confounded any association of secondhand with either elective poverty or a spiritual simplicity. The outfits signified a removal from mainstream society - the pursuit of a "straight" nine-to-five job — and a complete commitment to counterculture. Problematically, in their extremity of deviance, such anti-establishment garb began to echo aspects of economist Thorstein Veblen's 1899 discourse on “conspicuous consumption." Veblen called "elegant clothing” an "insignia of leisure," demonstrative of "the wearer's abstinence from productive employment." Arguably, the daily donning of a pirate outfit hobbled someone in search of mainstream employment much as a polished French heel negated the likelihood of manual labor seventy years prior. $^{131}$

\footnotetext{
${ }^{129}$ Los Angeles designer Holly Harp, a Radcliffe dropout from upstate New York, disagreed: "I was a junk-store-aholic. I couldn't drive by one without a snake charmer coming up and grabbing me. I would just buy every hand-me-down that they had." See Lobenthal, Radical Rags, p. 125.

${ }^{130}$ For accounts of the event, see Perry, The Haight-Ashbury, pp. 28-29; Chris Carlsson and Lisa Ruth Elliot, eds., Ten Years That Shook the City: San Francisco, 1968-1978 (San Francisco: City Lights Books, 2011), pp. 320-322; and Echols, Scars of Sweet Paradise, pp. 117-118.

${ }^{131}$ Additionally, elaborate sartorial expressions of leisure were not relegated only to female clothes. In the 1960s, the gender differences in clothing were elided to some degree by a "peacock revolution," which reversed the "great male renunciation" of brilliant color and refined form. Men, rather than exhibiting an unswerving devotion to drab-colored suits, opened up to a
} 
Media descriptions of free love and drugs and a communal repudiation of productive society soon made Haight-Ashbury a key destination for dropouts and runaways. For many of its mid-1960s habitués, Haight-Ashbury's sweet spot ended in 1967 , with the "summer of love," when as many as 100,000 people converged on the neighborhood. ${ }^{132}$ By the time of the Monterey Pop Festival, a June 1967, three-day concert in Monterey, California, "hip capitalism" elbowed original designers for storefront space at Haight-Ashbury. Gravenites (and Joplin) joined many in leaving HaightAshbury to the throngs of newcomers, attributing the decline of the hippie haven to hip capitalism, and claiming that "off-the-peg looks were antithetical to the iconoclasm of the original community." A battle began between some long-term residents and representatives of "store-bought hip' that didn't come from the soul." 133

\section{“A utopia would rise out of garbage." Abbie Hoffman}

In part to combat store-bought hip, a handful of political activists and improvisational actors (mostly from the guerilla theater group the San Francisco Mime Troupe) formed The Diggers. The group, who took their name from the Protestant

comparative variety of cuts and colors in the 1960s.Thorstein Veblen, The Theory of the Leisure Class: An Economic Study of Institutions (orig. published 1899; New York and London: The Macmillan Company, 1921), p. 171. Fashion historians debate the importance of the "so-called peacock revolution" and its influence over male style. For a skeptical analysis, see Fred Davis, Fashion, Culture, and Identity (Chicago: University of Chicago, 1992), pp. 34-35. See Also, Frank, The Conquest of Cool, pp. 183-195. In 1930, the psychologist J. S. Flugel popularized "the great male renunciation," the theory of that men's attire had recently shifted radically, from elaborate and colorful to somber and drab, in response to shifts in class and gender-including those stemming from the French Revolution. See J. S. Flugel, The Psychology of Clothes (orig. publ. 1930; New York: International Universities Press, Inc., 1971).

${ }^{132}$ Joan Didion's "Slouching Towards Bethlehem," offers one of the most affecting accounts of the situation of young hippies in 1967. In Slouching Towards Bethlehem (New York: Dell, 1968). See also, Tom Wolfe, The Electric Kool Aid Acid Test (New York: Bantam, 1969).

${ }^{133}$ Gravenites, qtd in Lobenthal, Radical Rags, p. 114; Echols, Sweet Scars of Paradise, pp. 188190. 
English agrarian radicals from the mid-seventeenth century, called themselves

"community anarchists." They vied against the general apoliticism of the Haight-Ashbury crowd and decried the groups who profited from "helping" the young pilgrims who quickly found out that the Haight's resources were not infinite, groups that for example, paid newcomers very little to make hippie handcrafts in turn sold to other HaightAshbury sojourners. ${ }^{134}$ Formed in 1966, the Diggers-Emmett Grogan and Peter Coyote were among the most well-known, though the group's philosophy included anonymity and equality among members - distributed protest pamphlets, served free meals at the Golden Gate Park, and staged theatrical protests like the October 1967 "Death of the Hippie March," a faux funeral protesting the countercultural commercialization pervading the summer of love. ${ }^{135}$ Perhaps the most "recognizable symbol of hippie politics," The Diggers marked a divergence from a counterculture presumed to be politically disengaged. ${ }^{136}$

Across the U.S., newly commercialized zones in hippie communities generated reactionary protests. Underground newspapers from Berkeley's Barb to Atlanta's The Great Speckled Bird, both of which took ameliorating domestic poverty and opposing the Vietnam War as central to their papers' mission, regularly excoriated hip capitalism. Early in 1969, a Speckled Bird journalist looked around Atlanta's Little Five Points and

\footnotetext{
${ }^{134}$ Tom Dalzell, Damn the Man!: Slang of the Oppressed in America (New York: Dover Publications, 2010), p. 178. Peter Coyote details The Diggers conflict with "hip capitalists," including the more progressive Haight Independent Proprietors (H.I.P.). See Coyote, Sleeping Where I Fall, pp. 74-77.

${ }^{135}$ See Echols, "Hope and Hype in Sixties Haight-Ashbury," p. 46; Issitt, Hippies: A Guide to an American Subculture (Santa Barbara, CA: Greenwood Press, 2009), p. 10.

${ }^{136}$ Issitt, Hippies, p. 7. For more on the Diggers, see "'It's Free Because It's Yours': The Diggers and the San Francisco Scene, 1964-1968," in Dominick Cavallo, A Fiction of the Past: Sixties in American History (New York: Palgrave, 1999), pp. 97-144; and Bradford D. Martin, The Theater in the Street: Politics and Public Performance in Sixties America (Amherst and Boston:

University of Massachusetts Press, 2004), pp. 86-124.
} 
saw a new middle class: "Bread and chicks and the all-American middle-class scene all over again, only this time with bell bottoms and long hair." ${ }^{137}$ Hippie enclaves simultaneously overrun by slumming youth and new hip capitalists highlighted the paradoxes of countercultural success.

In an article about Woodstock the month after the 1969 rock extravaganza, The Speckled Bird roasted hip imitators and brand buyers, negatively comparing the cheapened, newly produced style of elective poverty to the more approved appropriations of rock and roll. The "revolutionary energy of rock and of the movement is a response to oppression - it grew out of the blues, out of the poor white country music, out of the emancipated poverty of the street people and their drug scene." ${ }^{138}$ But in turn, this "emancipated poverty" encouraged the creation of styles imitated by wealthy posers with store-bought garb

... cut from finer cloth-bell bottoms, groovy vests, mucho hair, svelte girls in granny glasses. On the poor side, it's hip ... on the rich side, it's a schuck, it's an Imitation of Hip. It's fancy boutique clothes cut to look like old surplus clothes which the street people once wore out of poverty, thereby creating a style. ${ }^{139}$

Interestingly, the article's author identifies cross-class appropriation of fashions as more problematic than (poor) white appropriation of black musical styles. But despite these blows to the moral high ground of secondhand style, the political purposes of used goods became more clearly articulated than ever before in the late 1960s. Antiwar activists, feminists, and environmentalist were among those to cohere their reasons for dissent and to rely on secondhand exchange as elements of their protest.

\footnotetext{
${ }^{137}$ Susan Brenner, "Corruption," The Great Speckled Bird, Vol 1, no 35 (Feb. 24, 1969), p. 14. ${ }^{138}$ Italics in the original. The assessment of appropriation from "poor white music" as Mark Kramer, "Woodstock -3 Days of Peace?" The Great Speckled Bird, Vol. 2, no. 20, (July 28, 1969), pp. 7 and 17.

${ }^{139}$ Kramer, “Woodstock-3 Days of Peace?” p. 17.
} 
In practice and in underground media advocacy, antiwar protesters relied on secondhand venues such as thrift stores (useful receptacles of the "middle class's garbage") in their conjoined dissent against the Vietnam war and over-consumption. ${ }^{140}$ The Speckled Bird frankly advocated for a boycott of new goods, executed by a reliance on thrift stores. Those readers embarrassed to shop at such places, many of which were situated in parts of town associated with "the poor" and "winos" were "being had by the same wonderful folks who brought you the Cambodian invasion — and poverty in the first place." ${ }^{, 41}$ Jane Sass Collins, Harvard student and Vietnam War protester, said her cohort believed the rationale for the Vietnam War was a part of the "corporate lie" about the necessity for increasingly more material goods. The solution was to stop buying and instead decorate old clothes, make things, trade, and share. According to Collins, movement activists prescribed to a "belief that humanitarianism could trump materialism." $" 142$

As part of his attempts to link the counterculture and political protest, eccentric antiwar activist Abbie Hoffman saw in secondhand commerce common ground between aesthetic and political rebellions. Hoffman moved from California to a New York City East Side tenement in 1966, recommiting himself (after a divorce) to activism by opening Liberty House - a cooperative store selling homemade goods produced by the Poor People's Cooperative in Mississippi in order to raise funds for the Civil Rights Movement—and regularly contributing to undeground papers like the Village Voice and

\footnotetext{
${ }^{140}$ Bobi, "STP," The Great Speckled Bird 10 Aug 1970, p. 14

${ }^{141}$ Bobi, "STP," p. 14.

142 Jane Collins, "What I Got Out of the War," in Mary Susannah Robbins, ed., Against the Vietnam War: Writings by Activists (Syracuse, New York: Syracuse University Press, 1999), pp. 279-281.
} 
Liberation. ${ }^{143}$ At first, the apolitical attitudes of the East Side hippies disturbed Hoffman, but their creative appearances attracted him. By this time, rent was on the rise again in Greenwich Village. Much like the Beats from North Beach transformed into the HaightAshbury hippies, would-be Greenwich Village Bohemians moved into the East Village, and in greater numbers than either the 1910s Greenwich Village modernists or the postwar Beats. Secondhand clothes fueled theatrical parades at St. Mark's Place, and the most devoted actors increased the outrageousness of their appearance in resistence to fashion industry's imitation of secondhand — much as female Beats did a few years before in Greenwich Village. By 1967, New York City "hippies” had moved backwards from a 1920s flapper dress fad (after mainstream department stores mass-produced new versions) and introduced more whimsical elements of older Victorian and Edwardian styles, reminiscent of and possibly influenced by San Francisco style. ${ }^{144}$

Also by 1967, movement leaders like Hoffman and Jerry Rubin were invested in allying cultural and political radicals by including psychedelic public displays of style, music, and rebellion in practices of the antiwar coalition. ${ }^{145}$ Secondhand played a direct

\footnotetext{
${ }^{143}$ In 1967, Hoffman turned Liberty House over to the black community. See Hoffman, "Liberty House/Poor People's Corporation," Liberation (April 1967): 20; See also David Farber, Chicago '68 (Chicago: University of Chicago Press, 1988), pp. 7-9. For a biography of Hoffman covering his political life before and after this period, see Marty Jezer, Abbie Hoffman: American Rebel (New Brunswick, New Jersey: Rutgers University Press, 1992). See also Hoffman's autobiography, Soon to Be a Major Motion Picture, (New York: Perigee Book, 1980).

${ }^{144}$ The frug, a dance craze of the 1960s, inspired an interest in thrift store shopping in New York City as flapper dresses were discovered practical for the movements required. The frug involved rapid, frenetic motion and twisting. Dance fads By 1965, high-end designers modeled cuts after the shifts young dancers scored on the cheap, unabashedly adapting street style to the wealthy out-of-touch. See Patricia Peterson, "The Flapper Frugs," The New York Times 18 Sep 1965, p. SM104; Lobenthal, Radical Rags, pp. 96-97.

${ }^{145}$ Jezer, Abbie Hoffman, p. 117. For more on the conflicts and alliances between the counterculture and antiwar activists, see David Farber, "The Counterculture and the Antiwar Movement," in Melvin Small and William D. Hoover, eds., Give Peace a Chance: Exploring the Vietnam Antiwar Movement (Syracuse, New York: Syracuse University Press, 1992). At the end of that year, Hoffman, his new wife Anita, Jerry Rubin, Nancy Kurshan, and Parl Krassner,
} 
role in protests. For example, when planning for the "monkey theater" of the absurdist exorcism of the Pentagon on October 21, 1967, Hoffman relied upon the creative community to costume participants. The two vanloads of materials derived mostly from secondhand stores, rummage sales, and the Diggers' Free Store in New York City. Hoffman's Exorcism has been called an example of Dadaist art, "one of the significant collective aesthetic antiwar protest of the period. ${ }^{146}$ Twelve hundred people dressed as priests, witches, rabbis, gurus, sorcerers and so forth, invoked deities, and chanted (mostly "Out Demons Out") in the parking lot of the home of the U.S. Department of Defense. Their attempts to levitate the Pentagon failed, but as Norman Mailer explained in Armies of the Night "all evil emissions had fled."147

Free stores were part of The Diggers' central proposed solution to social problems - the cultivation of a society not dependent on monetary exchange. According to Digger Peter Coyote, "The Diggers understood that style was infinitely co-optable. What could not be co-opted was doing things for free, without money." 148 The Diggers fed the freaks for free, entertained in the streets for free (even though onlookers sometimes did not know it was a show), burned money, and organized free stores. In Diggers broadsides and pamphlets, they anonymously provoked "hip capitalists" and

would come up with the idea of "Yippies," as a protest scheme for the Democratic Nation Convention in Chicago. To satisfy press questions about what Yippie meant, Yippie became the Youth International Party, and spearheaded the 1968 Chicago protest that ended in riots and arrests. See Neil A. Hamilton, Rebels and Renegades: A Chronology of Social and Political Dissent in the United States (New York City: Routledge, 2002), pp. 262-263. For more on the events surrounding the Chicago protest, see Frank Kusch, Battleground Chicago: The Police and the 1968 Democratic National Convention (Chicago: The University of Chicago Press, 2008).

${ }^{146}$ See Matthew Israel, Kill For Peace: American Artists Against the Vietnam War (Austin, Texas: The University of Texas Press, 2013), pp. 77-78.

${ }^{147}$ Norman Mailer, Armies of the Night: History as a Novel, The Novel as History (New York City: Penguin Books, 1968), p. 120.

${ }^{148}$ Coyote, Sleeping Where I Fall, p. 35. 
tried to politicize hip consumers. In a pamphlet titled "The Trip Without a Ticket"—also the name of the original free store - the Diggers allied monetary commerce with war, oppression, self-loathing, insanity, and interpersonal estrangement. ${ }^{149}$ Additionally, naming the store "The Trip Without a Ticket" implied commentary on London's premier, posh antique clothing boutique, "Granny Takes a Trip.”

While the store was compared to a "hip Salvation Army," according to Emmett Grogan, only a "fraction of the goods used and accepted were secondhand and they were made available and displayed to affect a Salvation-Goodwill-salvage cover to conceal the fact that the rest of the stuff was new and fresh and had been stolen." ${ }^{150}$ The radical aims of The Diggers and their open willingness to steal firsthand consumer items obscured their message of the principled re-use of commercial goods. Still, free stores enjoyed nationwide urban popularity in the late sixties and early seventies, sometimes in connection with the Diggers or with similarly inspired cooperatives. For example, a tenmember collective in Buffalo, New York, ran a Free Store in the early 1970s "for the benefit of the poor whites, Puerto Ricans, Indians and freaks living in the neighborhood." The rhetoric surrounding these venues echoed the early socialist and cooperativemovement influences of Goodwill Industries. In apparently unconscious plagiary, even, a collective volunteer insisted that the program was "not a charity" but is "based on sharing

\footnotetext{
149“"The Trip Without a Ticket," Pamphlet, Originally published by the Diggers, ca. Winter, 19661967. Reprinted by the Communication Company SF $2^{\text {nd }}$ Edition 6/28/67. Included in The Digger Papers, August, 1968.

${ }^{150}$ Ralph Gleason, the music critic for the San Francisco Chronicle, coined the phrase "hip Salvation Army." According to Alice Echols account, Peter Coyote felt like it covered up the group's true radicalism, but another member thought Gleason was trying to create a cleaner image for the Diggers. Grogan's claims about stolen goods appear in his autobiography Ringolevio: A Life Played for Keeps (New York: New York Review of Books, 1972), p. 249.
} 
and cooperation. It's an alternative to American culture, which is based on competition."151

On the lower East Side of New York City, Abbie Hoffman used a Free Store to generate media attention and publicity for poverty aid and anti-war activism. Though he often ignored The Diggers' ideal of member anonymity, he embraced their principles of political theatrics. At the store's opening, he invited neighborhood kids to congregate and play dress-up. The store attracted the growing class of professional used clothing dealers, who took advantage of the free stock. ${ }^{152}$ Undeterred, Hoffman claimed that free networks of all kinds — free housing, free medicine, free clothing, and free food—could be sponsored by the excess of mainstream consumer society. "A utopia would rise out of garbage," Hoffman declared. ${ }^{153}$

For environmentalists, re-use also became an ecological imperative, and one that could be linked to cultural creativity and used to solve the old problem of suburban isolation and artistic stagnation. From the beginning of the popular call-to-arms over environmental distress in the United States, conversations centered on the harm of affluence - and its relation to effluence. Just months before the first Earth Day in 1970, President Nixon's State of the Union highlighted the national importance of the growing environmental movement, asserting that "wealth and happiness" were not synonymous. Time agreed, warning the populace that " $[\mathrm{t}]$ he U.S. environment is seriously threatened by the prodigal garbage of the world's richest economy." "154

\footnotetext{
151،"Sharing," Rags (Feb 1971, Issue 9), p. 20.

152 Jezer, Abbie Hoffman, p. 88.

153 Jezer, Abbie Hoffman, p. 88; and Hoffman, Soon to Be a Major Motion Picture, p. 97.

154 "Fighting to Save the Earth from Man," Time 95.5 (Feb. 2, 1970): 60.
} 
But in rhetoric like Hoffman's, 'garbage' became useful. In the pamphlet "Garbage or Nothing," the Diggers called trash "a medium." "Let's use it to act out our fantasies, use it for unimaginable gratifications." The idea of redeeming garbage had strong countercultural currency. Rebelling against the perceived fastidiousness of older generations, whose experience with the necessity of re-use bred contempt for the practice, "garbage" became a resource. "Diggers assume free stores to liberate human nature," they proposed, quoting Gary Snyder's proto-environmental claim that "Distrust of wildness in oneself literally means distrust of Wilderness." ${ }^{155}$ Through secondhand, and by quoting poets like Gary Snyder, the Diggers connected intellectually both to the fading Beat movement and to the emerging environmentalist movement.

So where did heightened political appeals and the imperative for re-use leave fashion? In 1970, Rolling Stone rock photographer Baron Wolman started an underground fashion magazine, Rags. The self-consciously un-slick, rag-paper publication ran for one year. It included advocacy for "communal closets," flea markets, and clothing co-ops, and featured designers, street fashion, and musicians' styles. At the same time, Baron funded the paper's production in part with advertisements for hip companies pandering to anyone looking to conform to an aesthetic alternative, like Truth and Soul, whose ads announced, "Most Americans wouldn't be caught dead in our clothes. We wouldn't be caught dead in theirs.",156

\footnotetext{
155 "The Trip Without a Ticket," Pamphlet.

156 "Truth and Soul," Rags, advertisement 9 (February 1971): 8.
} 
Fig 4.6. Advertisement for Truth and Soul Fashion. Rags (February 1971), courtesy of Baron Wolman.

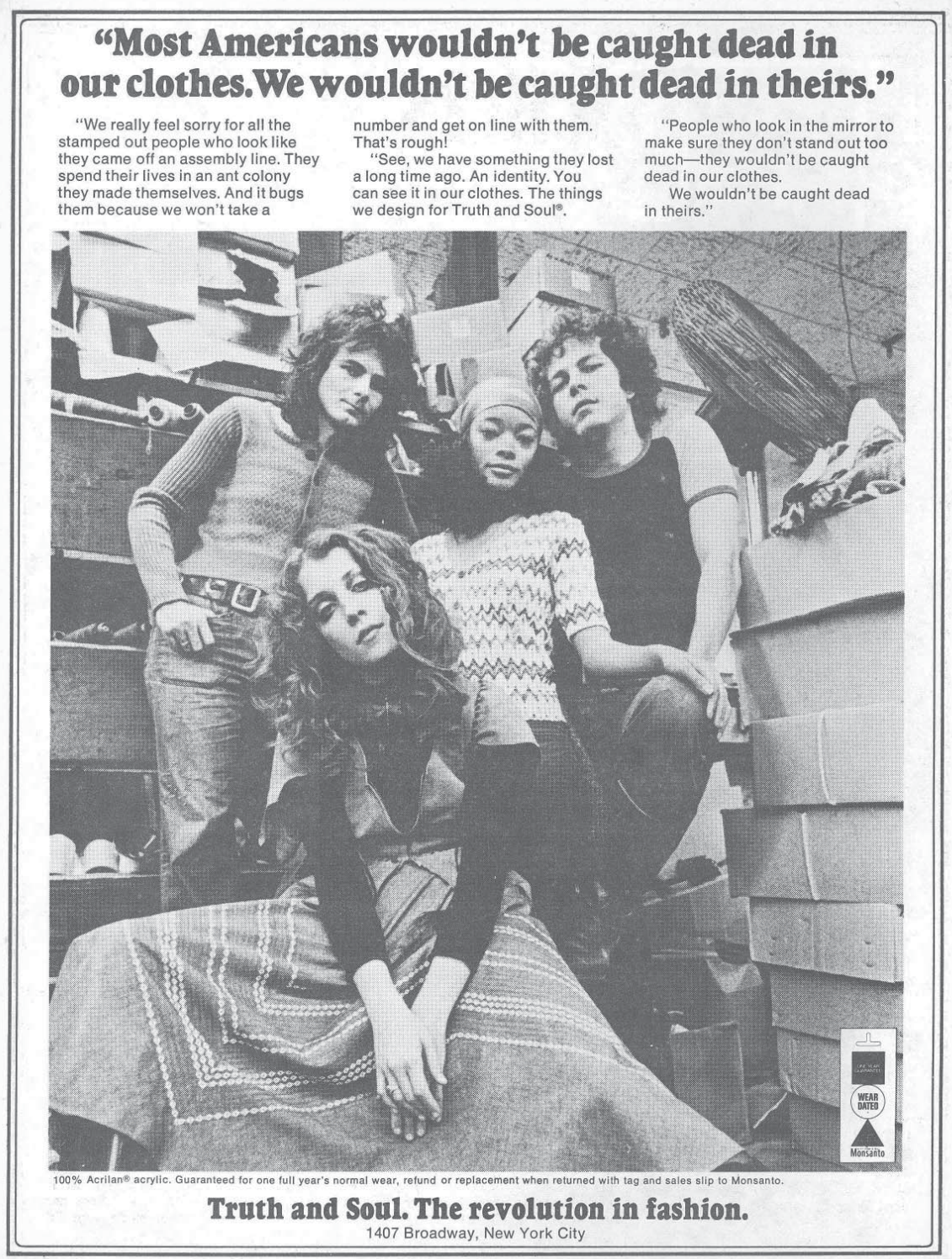

In Rags' opening mission statement, Wolman called fashion a "safety valve," "a boost of dressing up (and suggested Salvation Army as an inexpensive, legitimate source of good "threads"). ${ }^{157}$ He also insisted Rags was not frivolous. The magazine's writers often remarked in various ways, "Clothes are politics." 158 On the very next page of that

${ }^{157}$ Baron Wolman, "Letters," Rags 1 (June 1970): 1.

${ }^{158}$ Mary Jean Haley, “What Gay Women Wear,” Rags 10 (March 1971): 20. 
first issue of Rags, a brief blurb about an artist called "Charlie Nothing" underlined the paradoxes of elective poverty as means of combatting the problem of poverty. Nothing described his elaborate, handmade "suit of rags," designed for an art opening: "There are many colors in the rags, mostly faded. The rags are a ceremonial outfit which symbolically depicts the opposite of itself. For example, putting on clothes symbolizing poverty, and yet practically containing a great deal of work, implies poverty purchased at a price. . ."159 Charlie Nothing's statement summed up the philosophical paradox inherent in Jane Ormsby-Gore's claims of class deviance and in the elaborateness of hippie dress in general. ${ }^{160}$

Ambivalence and all, Charlie Nothing's suit of rags was the first of many instances of Rags portraying secondhand clothing as a political signifier. Clothing, and secondhand commerce, had very specific and heightened meaning for gender transgression, as the following chapter details. Rags magazine, as did underground papers nationwide in 1970, addressed "women's liberation," in this case through the valence of clothing. For example, an article called "What Gay Women Wear" quoted Susan Walsh proudly claiming that 'getting all dyked up' meant shiny boots and 'Salvation Armytailored, snazzy, comfortable clothes.' Walsh's choice of secondhand followed from the “women's liberation analysis that consumerism oppresses women." Walsh wore handme-downs, bought from thrift stores, or occasionally stole from a chain store. ${ }^{161}$ In

\footnotetext{
${ }^{159}$ Qtd in "Suit of Rags," Rags 1 (June 1970): 2.

${ }^{160}$ Sociologist Karen Bettez Halnon makes a similar point about "poor chic" later in the twentieth century, arguing that in "Poor Chic" "class status is distinguished through work abstention and conspicuous (wasteful) consumption. .." See Halnon, "Poor Chic: The Rational Consumption of Poverty," Current Sociology (July 2002): 501-516, p. 506.

${ }^{161}$ Haley, "What Gay Women Wear," 20.
} 
general, marginal consumerism represented marginal political stances, but minimizing contradictions remained a conundrum, as Charlie Nothing demonstrated.

\section{Conclusion}

From the early 1950s on, secondhand materials symbolized for some a rejection of the "marshmallow, plastic, and hopscotch" of "straight" postwar life. ${ }^{162}$ Academic and popular writings about the sixties acknowledge the prevalence of secondhand commerce in the 1960s but generalize its aim and truncate the duration of its popularity. Certainly, in both Europe and the United States, 1960s secondhand style had a powerful éclat previously uncharted. However, assertions that the "first hint of the merger of thrift and fashion was in the late 1960s" mislead and are part of a narrative summing up cultural and political rebellions of the 1960 s as, ultimately, failures. ${ }^{163}$

A partially elective poverty supporting the creation of styles in America based on castoff clothing dates back at least to the Greenwich Village Bohemia of the 1910s and continues still. By 1960 - the year by which as many American lived in suburbs as in cities - a contemptuous mainstream-media version of "beatnik" appearance included secondhand clothing and formed the basis for young, suburban imitators. ${ }^{164}$ By the end of that decade, environmentalists, Yippies, and feminists were among those who followed the Beat Generation's lead in using secondhand as a way to express allegiance to idealsaesthetic and political—countering the corporate capitalism of an unevenly affluent

\footnotetext{
${ }^{162}$ Peter Coyote, quoted in Nicholas von Hoffman, We Are the People Our Parents Warned Us Against (Chicago: Quadrangle, 1968), p. 131).

${ }^{163}$ Pamela Klaffke, Spree: A Cultural History of Shopping (Vancouver, B.C.: Arsenal Pulp Press, 2003), p. 115.

${ }^{164}$ Qtd in Alice Echols, "Hope and Hype in Sixties Haight-Ashbury,” p. 19. Beatnik wanna-bes like Joplin not only wore secondhand clothes, but men's shirts, presaging "the boyfriend look" that would be part of punk style in the 1970s. See Welters, "The Beat Generation," p. 164.
} 
America. The ostensibly simultaneous rise of trends in "vintage" clothing marketed to appeal to wealthy fashion nonconformists and infusing mainstream fashion with sensibilities seemingly coherent with the look of elective poverty challenged the political viability of secondhand in the eyes of some critics. But as the earlier establishment of the public's acceptance of "vintage" clothing as collectible suggests, the boutique trend is at least as rooted in 1950s college trends and department store divestment sales as in a cooptation of radical dressers' political styles.

In 1971, Abbie Hoffman started a publishing company of his own after more than thirty publishers rejected the book that would become a bestselling icon of subversion, Steal This Book. ${ }^{165}$ Parodying the faddish how-to and self-help genre of the time, Steal This Book included advice on how to fight against corporations and the government. The book's advice blurs the line between violently criminal and subversive, including sections on how to make bombs and on organizing food cooperatives. The chapter "Free Clothing \& Furniture" instructs the reader in the best ways to shoplift new clothing from department stores and also includes advice on how to get secondhand clothing.

By 1971, the number of free stores had diminished, but Hoffman included other ways to get discarded clothing: impersonate churches, ask people in the process of moving for clothes they intend to leave, fabricate a food and clothing drive for victims of a natural disaster, scour the lost and found at bus stations. Though Hoffman mostly advocates not spending money, he also mentions the cheap prices at Salvation Army

\footnotetext{
${ }^{165}$ Hoffman acknowledges that Izak Haber did much of the research for the book. Haber accused Hoffman of ripping him off. Izak Haber, "An Amerika Dream: A True Yippie's Sentimental Education or How Abbie Hoffman Won My Heart and Stole 'Steal This Book."' Rolling Stone 92 (September 30, 1971): 32-33.
} 
stores. ${ }^{166}$ By the end of 1971 , Hoffman had sold more than a quarter of a million copies of Steal This Book. ${ }^{167}$ The level of acceptance of secondhand shopping as a means of recreation and acquisition had never been higher. The early seventies saw a spike in the number of informal secondhand sales, especially in the form of flea markets and garage sales. And, as the protest movements of the late-1960s gave way to disillusionment, secondhand dress retained markers of dissidence, even as participants recognized the potential contradictions of anti-capitalist consumerism and dress. In order to better understand how anti-capitalist ideals supported the popularity of secondhand styles, the next chapter examines the relationship between those sentiments and gendertransgressive dress.

${ }^{166}$ Daniel Simon, ed., The Best of Abbie Hoffman (New York: Four Walls Eight Windows, 1989), pp. 209-210.

${ }^{167}$ Barbara L. Tischler, Sights on the Sixties (Rutgers University Press, 1992), p. 115. 


\section{Chapter Five \\ Genderfuck and the Boyfriend Look: \\ Gender Transgression and Secondhand Styles \\ "Every revolution begins with a change of clothes." Rene Bizet}

In a 1964 episode of the caveman cartoon The Flintstones, Fred Flintstone desperately wants to go to a baseball game. Barney has only one ticket, but as it is ladies' day at the ballpark, he can bring a female guest for free. Inspired by a box of his wife Wilma's unwanted clothes that she asks Fred to take to a rummage sale, Fred decides to try to "pass" as Barney's date. That plain box filled with "old clothes" opens the door to gender masquerade of the vaudevillian order-and of course, light-hearted confusion based on mistaken identities and the comic value of a caveman dressed in pink frills and a hat fit for British royalty. ${ }^{2}$

In general, the humor of The Flintstones hinged on juxtaposition. Ostensibly set in the Stone Age, The Flintstones featured clothing styles and technology contemporary to the airing of the show, but adapted to an aesthetic idea of caveman life. In the above episode, gender assumptions are layered on top of the show's constant theme of blending modernity with antiquity—-fittingly in this instance, through the use of discarded clothing. Those discarded clothes, in a liminal state of belonging, neither Wilma's anymore, nor yet anyone else's, presented the possibility for gender transgression in a

\footnotetext{
${ }^{1}$ French fashion critic qtd in Inez Millholland, "Change of Clothes, Change of Mind," Masses (February 1913): 3.

${ }^{2}$ In one of those twists of cartoon creative license (such as the way anvils never really hurt anybody), slender Wilma's rejected clothes mutate into a fair fit for blocky Fred. Perhaps Wilma dieted severely before the series' start, or maybe the donated clothes were Stone-Age maternity clothes. Ladies' Day, directed by Willan Hanna and Joseph Barbera (Nov. 23, 1962; Los Angeles, CA: Hanna Barbera, 1962).
} 
way that would not have been so readily suggested were they still lined up beside Wilma's Sunday best in her cave closet.

Four years after The Flintstones' cross-dressing episode, fashion designer Rudi Gernreich derided the hip use of secondhand clothing as essentially politically uninvolved, as "evasive." Gernreich, himself a gay rights advocate, argued that the rising trend in unisex fashion had much more currency as "a way of breaking down conventional attitudes of sexual behavior."”3 But like Fred, new owners of old garments often reimagined their acquisitions' originally intended purposes. Buying, selling, and wearing clothes from the past contributed to and reflected the breakdown of gender ideals in the 1960s and 1970s. Whereas the marketing of new clothes imposed stylistic conformity by clearly labeling items as men's or women's and organizing clothes by brand, cost, size, and even age, used clothing was comparatively stripped of these markers, inviting consumers to play fast and loose with sartorial signifiers. While breaching the sex-segregation of apparel, Gernreich's "unisex" line of clothing created yet another category, whereas secondhand outlets more often omitted such categories altogether. Additionally, in comparison to department stores, secondhand venues had few sales clerks working to steer shoppers towards items deemed appropriate for their class, race, generation, and —one of the most arbitrary yet uncompromising signifiers—gender.

In the 1960s and 1970s, gender-neutral dress, secondhand commerce, and a national focus on gay rights all grew in popularity. ${ }^{4}$ The recent politicization of style and

\footnotetext{
${ }^{3}$ Qtd in Jean Spain Wilson, "You Don't Need a Placard With the 'Unisex' Styles," The Washington Post 24 Jun 1968, p. C3.

${ }^{4}$ National attention to gay rights accelerated after the June 1969 uprising in response to a series of police raids at the Stonewall Inn, a gay bar in Greenwich Village For more on the Stonewall Uprising, see Betsy Kuhn, Gay Power!: The Stonewall Riots and the Gay Rights Movement, 1969
} 
personal appearance, as addressed in the previous chapter, supported the radicalization of secondhand shopping and dress. This chapter examines the role of used goods in the development of gay rights advocacy, glam rock, punk, underground art and film, and performance art, and argues that anti-capitalist ideals helped to popularize images of queer identities — which modeled sexualities not intended to be productive, but not necessarily homosexual — through the use of a trash aesthetic.

From female impersonator Jose Sarria to Bowery-browsing punk fashion-icon Patti Smith, thrift store wares, flea markets finds, junkyard discards, and street jetsam were central to the art, politics, and performances of many gender-transgressive figures of the 1960s and 1970s. Like Sarria, some secondhand enthusiasts explicitly questioned homophobic public perceptions and used secondhand exchange to support gay rights. Others, like underground filmmaker Jack Smith and Hibiscus, founder of the psychedelic drag troupe The Cockettes, presented a more ambivalent relationship to gay rights, citing anarchic, anti-monetary motivations for avoiding first-hand consumption and for presenting a "queer" appearance.

An anticommercial aesthetic popular among the postwar avant-garde improved the cachet of used materials and defined the look and the content of underground theater. As founder of the Theater of the Ridiculous Charles Ludlam remarked about the re-use habits of queer theatrics, "To have a new idea is as gauche as being seen in a new suit."

(Minneapolis, MN: Twenty-First Century Books, 2011); and David Carter, Stonewall: The Riots That Sparked the Day Revolution (New York: St. Martin's Press, 2004).

${ }^{5}$ Charles Ludlam, May 1970, qtd in Stefan Brecht, "Jack Smith, 1961-71. The Sheer Beauty of Junk," Queer Theatre: The Original Theatre of the City of New York. From the mid-6os to the mid-70s, book 2 (New York: Methuen Drama, 1978), p. 12. 
Or, as Jack Smith simply said, "Art is one big thrift shop."6 As part of experimental, “Off-Off-Broadway” theater, Ludlam, Smith, John Vaccaro, and Ronald Tavel all used secondhand materials to define alternative artistic performances for following generations, including for members of the San Francisco-based psychedelic drag troupe, the Cockettes.

The original Cockettes — who performed mostly in San Francisco from 1970 to 1972 — included gay, straight and bisexual men, women, and even babies. In a 1974 article in the magazine Gay Sunshine, the author coined the term "genderfuck" in reference to the troupe, applying it to a broad array of styles that indicated non-normative sexualities. ${ }^{7}$ Almost always, though, commentators applied the term to gender-bending men in dresses with hairy chests, glitter in their full beards, and long hair, men exemplified by the outrageous founder of the Cockettes, Hibiscus. The glitter-boy style of glam rock emerged from this flamboyant look, as several Cockettes members went on to work as stylists and designers, and for some time, relied on repurposed secondhand materials to create popular rock images of gender ambiguity.

Glam's flip side, its dirtier, do-it-yourself correlate, punk, also has firm roots in secondhand; "punk" and "hippie" are the two style categories most often linked to

\footnotetext{
${ }^{6}$ Jack Smith qtd in Ronald Tavel, "Maria Montez: Anima of an Antediluvian World," in Edward Leffingwell, Jack Smith, and Carole Kismaric, and Marvin Heiferman, eds.,in Flaming Creature: Jack Smith, His Amazing Life and Times (New York: Serpent's Tail, 1997), p. 99.

${ }^{7}$ See Christopher Lonc, "Genderfuck and Its Delights," Reprinted in Gay Roots: Twenty Years of Gay Sunshine, ed. Winston Leyland (San Francisco: Gay Sunshine Press, 1991), pp. 223-336. For personal accounts from members of The Cockettes, see Pam Tent, Midnight At the Palace: My Life as a Fabulous Cockette (New York City: Alyson Books, 2004), and Bambi Lake and Alvin Orloff, The Unsinkable Bambi Lake: A Fairytale Containing the Dish of Cockettes, Punks, and Angels (San Francisco: Manic D Press, 1996). See also Joshua Gamson, The Fabulous Sylvester: The Legend, the Music, The Seventies in San Francisco (New York: Henry Holt and Company, 2005), and Bill Weber and David Weissman. The Cockettes, documentary, 2002.
} 
secondhand. ${ }^{8}$ The erotically charged development of Patti Smith's iconic fashion underscored consistency in the use of secondhand in androgynous dress for both sexes. However, the public reception of cross-gendered dress suggested that men in women's clothes was more deviant, socially threatening, and politically radical than the converse. Descriptions of women in men's clothes as sporting "the boyfriend look" in the 1970s downplayed but did not erase possible feminist interpretations of cross-gendered dress. ${ }^{9}$

\section{"I'm a Boy": San Francisco and The Black Cat Café}

Before Charles Ludlam's Theater of the Ridiculous and Jack Smith's Flaming Creatures in 1960s New York City, and before The Cockettes can-canned in the 1970s, there was the grande dame of the Black Cat Café, Jose Sarria, aka Carmen, and later, Grand Empress of the Imperial Court. The Black Cat was already a favorite stomping ground for Beats (part of Jack Kerouac's On the Road was set in a fictional version of the joint) by the time Sarria began his performances in the mid-1950s. In the years following World War II's end, amid the "Lavender Scare" of the McCarthy Era, Sarria's politically engaged, satirical renditions of Carmen and Turandot helped make the Black Cat one of

\footnotetext{
${ }^{8}$ The bulk of studies on secondhand style in the 1960s-1970s refer to the English context and emphasize punk styles. See for example, Dick Hebdige, Subculture (London and New York: Routledge, 1979); Angela McRobbie, "Secondhand Dresses and the Ragmarket," in Angela McRobbie, ed., Zoot Suits and Secondhand Dresses: An Anthology of Fashion and Music (Boston: Unwin Hyman, 1988); and Louise Crewe and Nicky Gregson. Secondhand Cultures. (Oxford: Oxford International Publishers, Ltd., 2003)

${ }^{9}$ In Spree: A Cultural History of Shopping, Pamela Klaffke calls Diane Keaton in Woody Allen's 1977 film Annie Hall "the first poster girl for thrift shop chic. . with no ties to youth movements or to poverty." While Klaffke overlooks forerunners such as Janis Joplin in this assessment, Keaton's dress in Annie Hall did advertise for "the boyfriend look" by relying on men's clothing to create a hip, gamine appearance. See Klaffke, Spree (Vancouver: Arsenal Pulp Press, 2003), pp. 115-116. See also Annie Hall, directed by Woody Allen (1977; Beverly Hills, CA: United Artist), DVD.
} 
San Francisco's gay-friendliest spaces, prompting Allan Ginsberg to call it "the greatest gay bar in America."10

Beginning in 1948, the bar's owner, Sol Stoumen (a heterosexual man), fought against harassment on the part of the San Francisco police department and the Alcohol Beverage Control (ABC) Commission over the Black Cat's increasingly homosexual clientele. Finally, in 1951, Stoumen took the state to court over his suspended liquor license. The California Supreme Court, in Stoumen v. Reilly (37 Cal.2d 713) ruled that "[i]n order to establish 'good cause' for suspension of plaintiff's license, something more must be shown than that many of his patrons were homosexuals and that they used his restaurant and bar as a meeting place." ${ }^{11}$ The case, which restored the Black Cat's liquor license, was one of the earliest cases upholding the rights of homosexuals. The court qualified its opinion, however, by stating that $\mathrm{ABC}$ might still close gay bars with "proof of the commission of illegal or immoral acts on the premises," a caveat that might be interpreted to include any same-sex contact, such as dancing. ${ }^{12}$

Sarria's story is often repeated by scholars as an example of pre-Stonewall gay rights activism and political transvestism. ${ }^{13}$ At a time when homosexuals were deemed

\footnotetext{
${ }^{10}$ Ginsberg qtd in Benjamin Shepard, "History, Narrative, and Sexual Identity: Gay Liberation and Postwar Movements for Sexual Freedom in the United States," in Phillip L. Hammack and Bertram J. Cohler, eds., The Story of Sexual Identity: Narrative Perspectives on the Gay and Lesbian Life Course (New York: Oxford University Press, Inc., 2009), p. 33. For more on the Lavender Scare, see David K. Johnson, The Lavender Scare: The Cold War Persecution of Gays and Lesbians (Chicago: The University of Chicago Press, 2004).

${ }^{11}$ For more on Stoumen v. Reilly, see William Eskridge, Jr., Gaylaw: Challenging the Apartheid of the Closet (Boston: Harvard University Press, 2002), pp. 93-95; and Josh Sides, Erotic City: Sexual Revoutions and the Making of San Francisco, (Oxford and New York City: Oxford University Press, 2009), pp. 38-41.

${ }^{12}$ Eskridge, Gaylaw, p. 94.

${ }^{13}$ For more on Jose Sarria's life, performances, and political activism, see Michael R. Gorman, The Empress is a Man: Stories from the Life of Jose Sarria (New York: The Haworth Press, 1998); Nan Alamilla Boyd, "Transgender and Gay Male Cultures from the 1890s through the 1960s," in Wide-Open Town: A History of Queer San Francisco to 1965 (Berkeley: University of
} 
potentially treasonous security risks by the government and the American Psychiatric Association labeled homosexuality a mental illness, Sarria was unapologetically "out," both socially and politically. ${ }^{14}$ In the midst of years when San Francisco law, like the law in many U.S. cities, forebade the wearing of attire produced for the opposite sex, Sarria persisted in his chosen career as a female impersonator, a title in which he took professional pride. Sarria's drag performance was the second career threatened by laws concerning gender and sexuality; after being arrested and convicted on "morals charges," Sarria was forced to give up his hopes of being a certified teacher, towards which he had been studying. ${ }^{15}$

Sarria abhorred the double lives he saw many homosexuals living. His performance at the Black Cat became a political platform; in between songs, he preached "Gay is Good." He ended each show with a rousing parody of "God Save the [Nelly] Queen," encouraging the crowd to join in, "to get them realizing that. . . we could change the laws if we weren't always hiding." His advocacy culminated in a bid for Board of Supervisors a decade and a half in advance of Harvey Milk. ${ }^{16}$ In 1961, Sarria became the

California Press, 2003); Manuel Castells, "Cultural Identity, Sexual Liberation, and Urban Structure: The Gay Community in San Francisco," in The City and the Grassroots: A CrossCultural Theory of Urban Social Movements (Berkley and Los Angeles: The University of California Press, 1983); Mark Thompson, "Children of Paradise," in Corey K. Creekmur and Alexander Doty, Out in Culture: Gay, Lesbian, and Queer Essays on Popular Culture (Duke University Press, 1995).

${ }^{14}$ For more on the legal repercussion for homosexuality, see Johnson, The Lavender Scare. For more on the history of mental health and homosexuality, see Henry L. Monton, Departing from Deviance: A History of Homosexual Rights and Emancipatory Science (Chicago: The University of Chicago Press, 2002); Ronald Bayer, Homosexuality and American Psychiatry: The Politics of Diagnosis (Princeton: Princeton University Press, 1987).

${ }^{15}$ Jackie M. Blount, Fit to Teach: Same-Sex Desire, Gender, and School Work in the Twentieth Century (Albany: State University of New York Press, 2005), p. 99.

${ }^{16}$ Harvey Milk was the first openly gay man to be elected to public office in California, when he won a seat on the San Francisco Board of Supervisors in 1977. For more on Milk, see Randy Shilts, The Mayor of Castro Street (New York: St. Martin's Press, 1982); and Kari Krakow, The Harvey Milk Story (Ambler, Pennsylvania: Two Lives Publishing, 2001). 
first openly gay man to run for public office in the U.S. He conducted his campaign partly in drag, as part of his by-then renowned shows. ${ }^{17}$

By this time, Sarria's wardrobe of gowns, heels, and hats was prodigious, but his penchant for dresses and women's shoes began long before, at the home of his Columbian-born single mother, a domestic servant who had only occasional care of her son. Both his mother and his aunt indulged Sarria's boyhood delight in dressing up in gowns and heels, playing a duchess, and acting out narratives of royal balls. ${ }^{18}$ Jose's first drag costumes were secondhand clothes he scavenged from the closets of female relatives. His evolution into full drag also relied on hand-me-downs. In early performances, Sarria tinkered with women's slacks and makeup, but wore loafers until a female patron gifted him the pointed, high-heeled Capezios from her feet, a footwear style he favored ever after. ${ }^{19}$

As Sarria transformed himself into Carmen, diva of The Black Cat, and later, the Empress of the Imperial Court System, he relied in part on the city's many thrift stores and flea markets. At least by 1960, Sarria was buying women's clothing from the Salvation Army, Goodwill Industries, and the Purple Heart Thrift Store. Later handwritten accounts also reflected a budget for — and an income from—-flea market sales. ${ }^{20}$ Sarria supplemented both his wardrobe and his personal income through the exchange of secondhand clothing. The task of constructing Carmen and his other

\footnotetext{
${ }^{17}$ Gorman, The Empress is a Man, 162; David Talbot, Season of the Witch: Enchantment, Terror, and Deliverance in the City of Love (New York: Free Press, 2012), pp. 102-103.

${ }^{18}$ Shilts, The Mayor of Castro Street, p. 51.

${ }^{19}$ Boyd, Wide Open Town, p. 22.

${ }^{20}$ Based on receipts from Jose Sarria Papers (photo box 6, \#1996-01), San Francisco GLBT Historical Society.
} 
personas would have been more difficult without inexpensive, used clothes and the relative permissiveness of secondhand commerce venues. ${ }^{21}$

Compounding the difficulty of affording a double wardrobe — male dress for everyday public life and female dress for his career and enjoyment—were the legal dangers of purchasing women's clothing firsthand. As secretary of the first gay civil rights organization he helped start in 1961, The League for Civil Education (LCE), Sarria reported the dangers of mainstream shopping for those venturing outside of gender normative dress: "Macy's still continues to be a source of revenue for attorneys defending silly queens who insist on going there to shop at the T room. ${ }^{.22}$ As long as wearing the clothing of the opposite sex was illegal, shopping for those clothes in a department store meant risking not only reputation, but arrest.

While not very popular or effective, the LCE set the stage for two more gay organization Sarria helped start, the San Francisco Tavern Guild (1962-1995) and the Society for Individual Rights (SIR) (1964-1976). The Tavern Guild was the first gay business association in the U. S., established by gay bar owners and liquor wholesalers in reaction to police harassment that closed several bars. ${ }^{23}$ The Tavern Guild, while successful in many endeavors, could not prevent the final closing of The Black Cat in 1963. His work place shuttered, Sarria joined forces with other activists to form SIR,

\footnotetext{
${ }^{21}$ Sarria's papers did also include records of purchase from mainstream department stores, including dresses. Sarria Papers, \#1996-01.

${ }^{22}$ Bulletin, League for Civil Education, (April 15, 1961; Jose Sarria Papers, LCE documents), GLBT Historical Society; Boyd, Wide Open Town, p. 222; For more on the Tavern Guild, see Susan Stryker and Jim Van Buskirk, Gay By the Bay: A History of Queer Culture in the San Francisco Bay Area (San Francisco: Chronicle Books, 1996) and Bob Peck, "San Francisco Has America's Most Successful Tavern Guild," VR (Feb, 1971). For the Society for Individual Rights' statement of policy, see Robert B. Ridinger, ed., Speaking for our Lives: Historic Speeches and Rhetoric for Gay and Lesbian Rights (1892-2000), (Binghamton, New York: Harrington Park Press, 2004), pp. 115-116.

${ }^{23}$ Boyd, Wide Open Town, p. 220.
} 
which became the largest grass-roots homophile group of the era. SIR modeled new trends in gay activism by demanding fair legal treatment while openly and noisily protesting police oppression. The group became a model for similar organizations in major U.S. cities. ${ }^{24}$ In 1965, Sarria rounded out his record of community building by established the Imperial Court System, of which he crowned himself Empress. The group created a gay social network and provided a platform for public expression by and for homosexuals—especially the "nellies" Sarria so supported—often using drag events to fundraise for gay charitable causes. ${ }^{25}$

These homophile organizations all participated in secondhand commerce for various, sometimes contradictory, purposes, including raising funds for gay rights advocacy, clothing community members who came to the organization for employment help, and distributing elaborate gowns in preparation for the annual Hallowe'en Ball—the one day of the year drag was not an arrestable offense. In the mid-1960s, SIR's monthly newsletter, Vector, printed warring views of appropriate dress for homosexuals seeking public acceptance, and proposed similarly divergent uses of secondhand. These discussions of clothes trace the cultural transition from assimilatory homophilic rhetoric to the blossoming of a queer community. As radical as Sarria's own life and dress was, he occasionally acquiesced to mainstream expectations, such as during his 1961 bid for office. While he informally campaigned as Carmen during his act at The Black Cat, Sarria reportedly purchased his first men's suit for more formal civic presentations. ${ }^{26}$ Sarria took his run seriously and extended his platform beyond issues of homosexual

\footnotetext{
${ }^{24}$ William N. Eskridge and John Ferejohn, A Republic of Statutes: The New American Constitution (Yale University Press, 2010), p. 159.

${ }^{25}$ Marc Stein, Rethinking the Gay and Lesbian Movement (New York: Routledge, 2012), p. 69.

${ }^{26}$ For one description of Sarria's bid for office, see Thompson, “Children of Paradise," p. 450.
} 
rights. His suit indicated a partial adaptation to "straight" constituents' expectations. Sarria frequently maintained that not all of the 6,000 votes he received were from homosexual voters. ${ }^{27}$

The Vector published assimilatory rhetoric during the publication's early years, in accordance with the mission statements of some early homophile affiliates, such as the Community Services Committee of SIR, sponsors of the very first gay community center in the U.S. ${ }^{28}$ In 1965, an article publicized the Community Services Committee's chief aims, among which was to gain rights for homosexuals by "teaching the Heterosexual that he is not so different." ${ }^{29}$ To do this, a spokesperson advised that "the Homosexual" show a normative face by preventing the spread of venereal disease and "the spread of the conception of the stereotype homosexual racing about in semi-transvestic garb."30 The same issue of Vector in which this plea appeared also requested the donation of used clothing in good condition for people coming to the Committee for employment referrals. The garb requested was very "straight" — suits, ties, white shirts, versions of the conservative, gender-appropriate dress male picketers outside the Civil Service Commission were careful to don when protesting the ban on the employment of gays that same year. ${ }^{31}$

\footnotetext{
${ }^{27}$ Boyd, Wide Open Town, p. 220.

${ }^{28}$ Bonnie Zimmerman, ed. Encyclopedia of Lesbian and Gay Histories and Cultures (New York: Garland Publishing, 2000), p. 192.

${ }^{29}$ Nancy May, "Speaking Out," Vector 1.6 (May 1965): 3, from Sarria Papers, \#1996-01. ${ }^{30}$ May, "Speaking Out," p. 3.

31 "Clothing Needed," Vector 1.6 (May 1965): 3, Sarria Papers, \#1996-01; Women picketeers wore correspondingly conventional outfits. For more on the 1965 picket, see Johnson, The Lavender Scare, p. 202-205.
} 


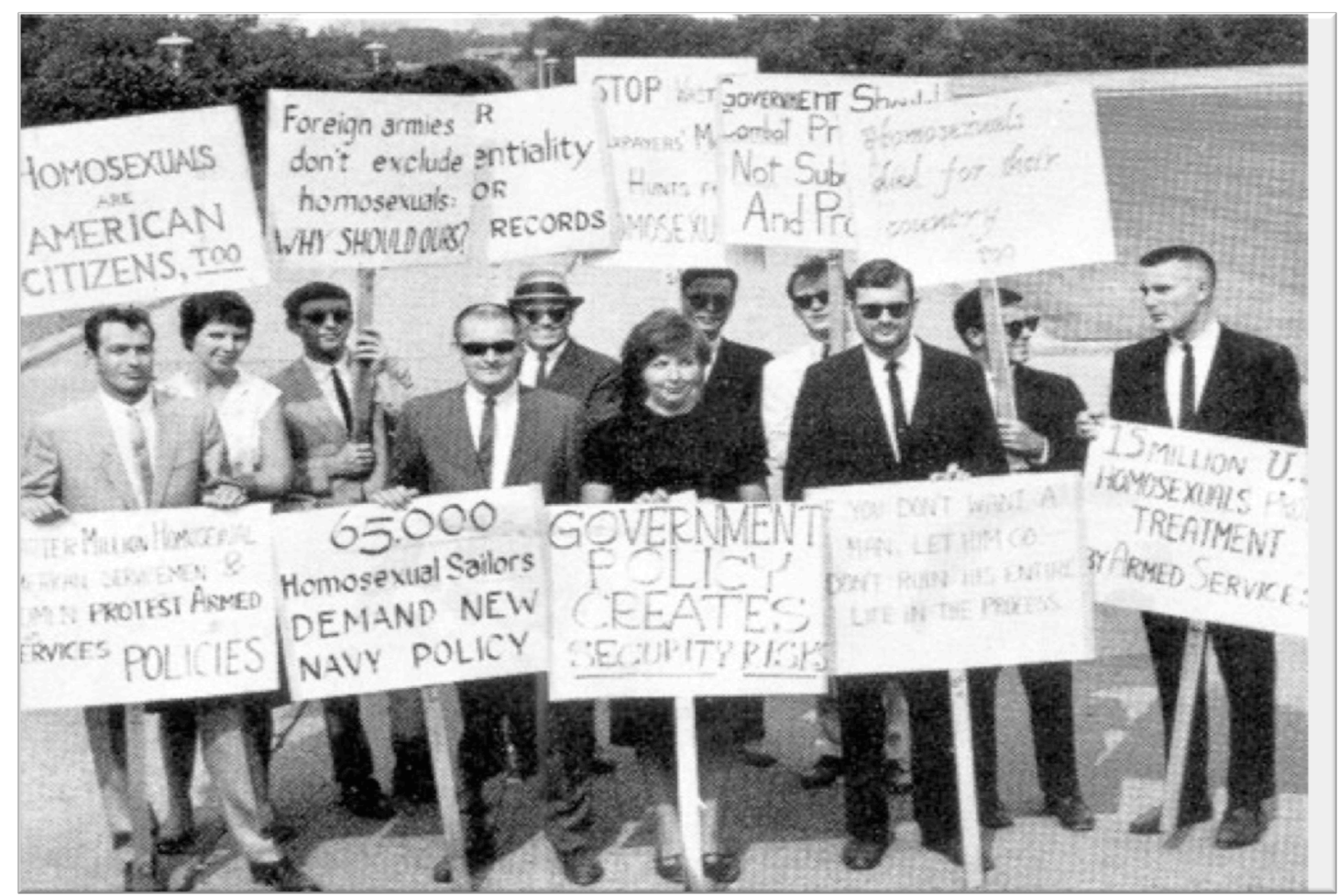

Fig. 5.1. First White House gay rights protest, 1965.

In an issue of Vector just one year later, though, SIR's co-op and thrift store, the SIRporium (by 1966, one of three primary sources of income for the group), boasted of a wide array of "Hallowe'en gowns" for their annual drag ball. ${ }^{32}$ Although Halloween was indeed the one night when drag was legal, police officers often waited outside the ball venue, ready to catch gown-clad men after midnight, in a modern-day, cross-dressing Cinderella plight. At that year's ball, Sarria helped circumvent the law against crossdressing, which included the phrase "intent to deceive," by handing out tags in the shape of black cats for men to put on their dresses. The tag read, "I am a boy.",33 The Tavern Guild, which sponsored the Ball, also frequently raised funds with the sale of secondhand

\footnotetext{
32،"The SIRporium a Success," Vector 1.9 (September 1965): 10; See also "What's Happening at the SIRporium," Vector 2.12 (November 1966): 4.

${ }^{33}$ Gorman, The Empress is a Man, p. 179.
} 
goods destined for cross-gendered wear. Between March 20 and April 9 of 1967, the Tavern Guild held eight fund-raising auctions, featuring performances from San Francisco's most "outstanding stage performers," as well as "the clothes off their backs." The profits went into the creation of a Gay Community Fund. ${ }^{34}$

In the mid-1960s, inside and outside of gay communities, changes in attitudes about gender-deviant dress emerged and spread, and this transition period could account for some of the contradictory ideas about dress expressed in Vector. By 1967, Vector journalists openly acknowledged the influence of hippie dress on public perceptions of gay dress. The author of "Drag — is it Drab, Despicable, Divine?" argued against conforming to ideals of "social acceptability" in clothing. The "“drag dress' problem" extended to all men and women, the author wrote, because choices of style should not determine public assumptions of wearers' sexual identification. In this respect, the author argued, hippies "show maturity and logic in dispensing with this inhibiting social claptrap. ${ }^{35}$

A few years later and just a few blocks away from the site of The Black Cat, a group emerged whose secondhand style epitomized this "maturity and logic": the Cockettes. Despite their proximity, key members of the Cockettes were completely unaware of the existence of Sarria or his organizations. This disconnect between neighboring queer communities reveals the disparate intentions and affinities of nearly interlocking movements. The differences between The Cockettes and Sarria showcase the broad range and meaning of styles and politics that were considered part of "cross-

\footnotetext{
${ }^{34}$ Daughters of Bilitis San Francisco Chapter Newsletter, from Sarria Papers, \#1996-01, Box 7; see also, B. Plath, “T.G.S.F. Auction Series is Another Success," Vector 3.6 (May 1967): 12.

${ }^{35}$ W.E. Beardemphl, “Drag —is it Drab, Despicable, Divine?” Vector 3.6 (May 1967): 13.
} 
dressing," as well as the equally various motivations for participation in secondhand clothing exchange.

Though the Cockettes' psychedelic performances are often referred to as gay liberation theater, most members described their lineage as more related to hippies than "the old generation" cross-dressers - not all members were gay, or even male. Two of the original Cockettes, Rumi Missibu and Fayette Hauser, made it through the twentieth century without ever hearing of Sarria or his political agenda, testifying to their own disinterest in direct gay liberation politics or San Francisco's homophile history. To Fayette, "Cross-dressers were another old generation ... these fat men who'd put on old ball gowns and bad wigs." ${ }^{36}$ Sarria was the establishment, part of the old economy of style and sexuality.

Unlike Sarria many of the influential gender-trangressive secondhand aficionados of the 1960s and 1970s were anticapitalist. Much of the "queer theatre" emerging at that time, shaping underground cinema, performance art, and eventually, popular musical styles and even mainstream fashion, was predicated on anticapitalist sentiment. For centuries, movements of social and sexual liberation had been associated with campaigns of radical anticapitalism. The original, English Diggers took part in the civic unrest of the mid-1600s to advocate for community building that emphasized expression of free love and a rejection of wealth and consumption. In San Francisco, the political performers who named themselves after the English Diggers considered liberation from money and the making of a "free" society as the rationale behind ideals of sexual freedom; in fact, the theatrical troupe began in 1967 and only pronounced sexual liberation as part of their ideology following the summer of love, seeing the trend as an opening for the spreading

\footnotetext{
${ }^{36}$ Hauser, telephone interview with author, November 22, 2010.
} 
of their anticapitalist rhetoric. ${ }^{37}$ When sexuality, whether clearly "straight" or not, was presented as not procreational but for personal expression, it often acted, even incidentally, as a form of anticapitalism. ${ }^{38}$

\section{The "Hidden Source": Jack Smith and New York City Avant-Garde Theater}

New York City's 1960s avant-garde art scene filled in the gaps in sexual politics and aesthetics between Sarria and The Cockettes. In the mid-1960s the theatre of the Ridiculous emerged as "a definable sensibility in American theatre" associated with the playwrights Kenneth Bernard, Charles Ludlam, and Ronald Tavel, and director John Vaccaro, who started the Play-House of the Ridiculous in 1965. The genre of Ridiculous Theatre was a highly self-conscious style that broke with dominant trends of naturalistic acting and realistic settings. It tended toward "camp, kitsch, transvestism, the grotesque, flamboyant visuals, and literary dandyism. ${ }^{, 39}$ Ridiculous often relied on parodies of icons and artifacts of the American entertainment past—old movies, popular songs, advertisements, and television. Just as importantly, it cultivated a trash aesthetic dependent on the use of secondhand materials for costumes and sets.

\footnotetext{
${ }^{37}$ Talbot, Season of the Witch, pp. 35-41. For more about the Diggers, their performance style, and evolving anarchic principles, see Bradford D. Martin, The Theatre is in the Street (Amherst and Boston: University of Massachusetts Press, 2004), pp. 86-124.

${ }^{38}$ John D'Emilio tracks the changes of the meaning of heterosexual relations and family life throughout the transition from the economic self-sufficiency of family units to a capitalist free labor society. See D'Emilio, "Capitalism and Gay Identity," Powers of Desire: The Politics of Sexuality, Ann Snitow, Christine Stansell, and Sharon Thompson, eds. (New York: Monthly Review Press, 1983), pp. 101-103

${ }^{39}$ Bonnie Marranca and Guatam Dasgupta, Theatre of the Ridiculous, (New York: Performing Arts Journal Publications, 1979), p. 6. For more on Ridiculous theater, see Stephen J. Bottoms, Playing Underground: A Critical History of the 1960s Off-Off-Broadway Movement (Ann Arbor, Michigan: University of Michigan Press, 2006); and David Kaufman, Ridiculous! The Theatrical Life and Times of Charles Ludlam (New York: Applause Theatre \& Cinema Books, 2002). For critical analyses of the plays produced by Ludlam's company, see Rick Roemer, Charles Ludlam and the Ridiculous Theatrical Company (Jefferson, North Carolina and London: McFarland \& Company, Inc, 1998).
} 
While these directors were vital to disseminating Ridiculous theater, Jack Smith, actor, artist, photographer, and underground filmmaker, is the acknowledged "father of the style." ${ }^{40}$ Film and theatre critic (and son of playwright Bertoldt Brecht) Stefan Brecht quoted Ludlam as admitting, "Jack is the daddy of us all.."1 Vaccaro cited Smith as "[p]robably the biggest influence" on his life and "the pure artist of our day." ${ }^{42}$ From Andy Warhol to "pope of trash" John Waters to David Lynch, experimental filmmakers credited Smith's influence. Art photographer Cindy Sherman and performance artist Lorrie Anderson acknowledged his work, as did musicians Lou Reed and David Byrne, to name just a few of his admirers. Richard Foreman, acknowledged pioneer of avantegarde theater, went so far as to say that Smith was "the hidden source of practically anything that's of any interest in the so-called experimental American theater today." ${ }^{43}$ Many of these artists went on to great success by using Smith's aesthetic ideals without prescribing to the anti-commercial principles girding his art. Smith never abandoned anticommercialism as he established his trash aesthetic. Rather, other ambitious artists who admired Smith's work used his aesthetic to create widely admired art not intended to take a stance against affluence or a capitalist system.

\footnotetext{
${ }^{40}$ Bonnie Marranca calls Smith the "father of the style" in the introduction to a compilation of Ridiculous screenplays and scripts. See Marranca, "Introduction," in Marranca and Dasgupta, Theatre of the Ridiculous, p. 5.

${ }^{41}$ Stefan Brecht, "Family of the f.p. The Theatre of the Ridiculous, 1965-1968," Queer Theatre, p. 28 .

${ }^{42}$ Kenneth Bernard, "Confronting the Ridiculous/A Theatrical Review with John Vaccaro," Confrontations (Spring/Summer 1976), qtd in Brecht, "Family of the f.p., p. 28.

${ }^{43}$ Richard Foreman founded Ontological-Hysteric Theater in 1968. For more on Smith's broadspanning influence, see "The World According to Jack Smith," in C. Carr, On Edge: Performance at the End of the Twentieth Century (Middletown, CT: Wesleyan University Press, 1993), pp. 325-328. For more about Smith's influence on and relationship to avant-garde art, see Jerry Tartaglia, "The Perfect Queer Appositeness of Jack Smith," in Wheeler Winston Dixon and Gwendolyn Audrey Foster, eds., Experimental Cinema: The Film Reader (London: Routledge, 2002), pp. 163-172. Jack Sargeant includes Jack Smith in the category of "Beat Cinema" in his book Naked Lens: Beat Cinema (orig publ. 1997, Berkeley: Soft Skull Press, 2008), pp. 101-110.
} 
Smith's work crafted and typified the Ridiculous sensibility, and it did so with a near-obsessive reliance on secondhand materials. Jack Smith embraced a trash aesthetic in his work from the start of his career, which began with photography shortly after he moved to New York City in 1953. There, he furnished his apartment from discards found on the street. He continued to layer his abode, a loft that would become the site of plays and movies, with fabrics and objects meticulously arranged. ${ }^{44}$ As Brecht described it, the feet-deep layers of refuse, including a junk-filled old toilet, feathers, netting, bottles, metal, plastic, were all defined by the "disruption of function," and presented "a sensitively restrained encroachment on a chance disorder." ${ }^{, 45}$ There, Smith would conduct, construct, and perform in long, time-bending shows, displays which both included and disregarded its audience with sets that privileged elaborate arrangements of discarded materials. He himself appeared dressed in outfits "fresh from the thrift shop."

Much of Jack Smith's work relied for its compelling effects on his elaborate use of junk as representative of desire — personal, collective, and abstract. Smith's creations were slipstream bricollage, flitting through categories of time, subject, and even medium. His style culminated in a form of expression later labeled "expanded cinema." Through his multidisciplinary art (prose, film, photography, performance), he "collapsed the distinction between the development of an event and its performance." His use of time was an aspect Warhol, who referred to Smith as the only man he would ever copy,

\footnotetext{
${ }^{44}$ Leffingwell, “The Only Normal Man in Baghdad," Leffingwell et al., ed., Flaming Creature pp. 71,78 .

${ }_{45}$ Brecht, qtd in Leffingwell, "The Only Normal Man in Baghdad," p. 78.

${ }^{46}$ Michael Moon, "Flaming Closets," in Moon, ed. Small Boy and Others, (Durham and London: Duke University Press, 1998), p. 90. See also Judith Jerome, Creating the World Waiting to Be Created: Jack Smith and D. W. Winnicott (dissertation, Department of Performance Studies, New York University, May 2007), pp. 322-325.
} 
especially admired. ${ }^{47}$ Smith's use of objects "out of time" were intrinsic to his temporal experimentations, aiding in disorienting the observer with disjunctive settings.

Brecht emphasized the specific metaphorical importance of Smith's cluttered settings: "the bottles, containers, old Xmas trees, signs, broken toys, baby carriages that compound his stage setting. . . have all been carefully arranged and this has taken a long time because many minute rearrangements were needed." 48 As a result, "The heap glitters melodiously. It is clearly exotic, a landscape of desire." 49 Smith used abandoned materials to represent the potential beauty in people, ideals, and aesthetics considered "low" by middle-class consumers. Smith's aesthetic universe illustrated Abbie Hoffman's claim that "utopia would rise out of garbage.",50

A touching quality of naiveté and hopefulness resides in his work, masked by seemingly disjunctive accessories and settings. Gender disruption underscores the subject matter in such a way that makes for striking images and re-interpretive content, as in Figure 5.2, a photographic staging of Eve in the garden, eating the forbidden fruit. The serpent as a vulture and a gender-ambiguous Eve (and perhaps the slightly outré choice of pomegranate as the fruit) just remove the iconic scene from realism. This early photograph (c. 1958-1962) reveals Smith's sartorial philosophy. Instead of a mere figleaf, Eve is entirely swathed in reams of wrinkled, blue, uncut fabric. Smith mocks a central purpose of clothing, modesty, by completely covering Eve's body. At the same time, by creating a sexually ambiguous Eve, he parodies the role of dress as a mode of gender

\footnotetext{
${ }^{47}$ See Kenneth Goldsmith, ed., I'll Be Your Mirror: The Selected Andy Warhol Interviews: $1962-$ 1987 (New York: Carroll and Graf Publishers, 2004), p. 67; Leffingwell, "The Only Normal Man in Bagdad," p. 70.

${ }^{48}$ Stefan Brecht, "The Sheer Beauty of Junk," in Leffingwell et al., ed. Flaming Creature, p. 43. Originally published in Queer Theater, (Frankfurt Germany: Suhrkamp, 1978).

${ }^{49}$ Brecht, "The Sheer Beauty of Junk," p. 43.

${ }^{50}$ Hoffman, Soon to Be a Major Motion Picture, p. 97.
} 
identification - dress can be extended to include make-up and jewelry - the right-hand ring and the barely visible bracelet on Eve's right arm.

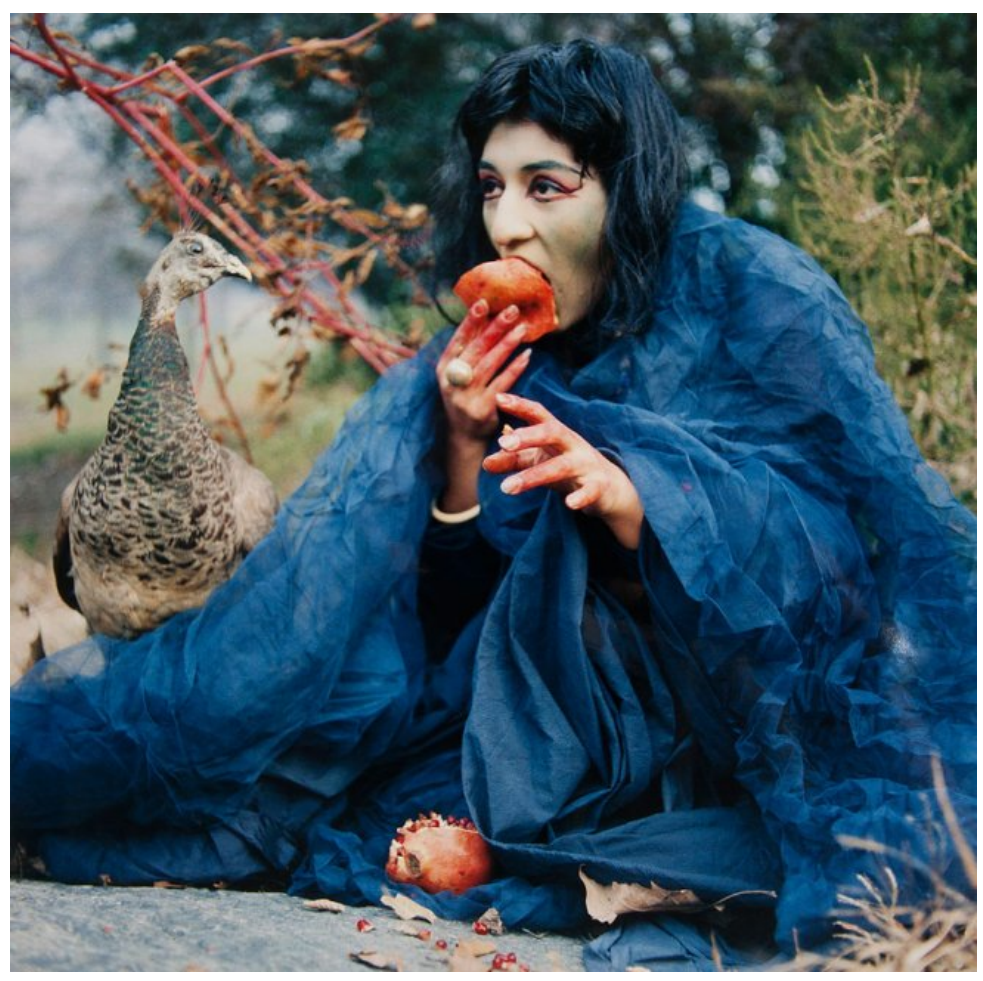

Fig. 5.2. Jack Smith, Untitled c. 1958-1962. Analog C-print handprinted from original color negative on Fuji Crystal Archive paper. Copyright Estate of Jack Smith. Gladstone Gallery, New York and Brussels.

Though his photographs might be his most highly regarded artistic works, Smith is best known for his sexually graphic film Flaming Creatures, which contains many of the distinguishing elements of Ridiculous theatrics. Smith claimed he intended the film to be a comedy "set in a haunted music studio." ${ }^{51}$ A satire of Hollywood B movies, Flaming Creatures highlighted Smith's obsession with Dominican-Republic born actress Maria Montez, star of Technicolor costume adventure films of the 1940s, such as Arabian Nights (1942) and Ali Baba and the Forty Thieves (1944). Flaming Creatures' central

\footnotetext{
${ }^{51}$ Jack Smith quoted in J. Hoberman, On Jack Smith's Flaming Creatures (and Other Secret-Flix of Cinemaroc) (New York City: Granary Books, 2001), p. 17.
} 
character, Mario Montez, paid tribute to the "Queen of Technicolor." did not see the eerily colored panoply of sexual gyrations as the humorous homage Smith considered it. Police promptly seized the film at its premier on April 29, 1963, at the Bleeker Street Cinema in New York, and Flaming Creatures became the center of antiporn controversy for a time, and, as one film critic supposed, "probably the only American avant-garde movie ever described in the Congressional Record. ",53 According to Smith, though, Flaming Creatures shocked not because of its depictions of sex acts between same, mixed, and ambiguous genders, but because of its aesthetic of imperfection, including the use of old clothes. His critics were, he said, "[s]hocked by the seaminess of images of sexpartners not attired in brand new garments moments fresh from the dry cleaners." ${ }^{, 54}$ At least to Smith, the choice of torn and obviously outdated clothing was a greater form of subversion than the absence of clothing. The old fears about used clothing as vectors of disease - moral as well as physical—endured. The desire for clothing to project an orderly external appearance was part of the aftermath of original sin, as implied by Figure 5.2. Critics of the film assumed that bedraggled appearances signaled depravity. To Smith, both disarray and nudity

\footnotetext{
${ }^{52}$ For more on the filming and reception of Flaming Creatures, see Hoberman, On Jack Smith's Flaming Creatures. Maria Montez was dubbed the "Queen of Technicolor" in the trailer for Arabian Nights - but was not highly regarded as an actress. See Ernest Mathjis and Jamie Sexton, Cult Cinema (John Wiley \& Sons, 2012). According to Sheldon Renan's The Underground Film, Jack Smith discovered the transvestite star Mario Montez (or Dolores Flores) in a subway station. Montez went on to appear in numerous underground films, including many of Warhol's film, such as (but not only) Mario Banana and Harlot (both 1964), Camp (1965), The Most Beautiful Woman in the World aka The Shoplifter (1965), and The Chelsea Girls (1966), in addition to his theatrical performances. See Renan, The Underground Film: An Introduction to Its Development in America (Studio Vista Books, 1967), p. 202.

${ }^{53}$ For more on the film's censorship and legal punting, see J. Hoberman, "Sight and Sound: Everything Overexposed," New York 1.9 (January 1992): 4. For more on the public controversy including Susan Sontag's defense of it, see also Peter Decherney, Hollywood and the Culture Elite: How the Movies Became American (New York: Columbia University Press, 2005), pp. 198199.

${ }^{54}$ Leffingwell, “The Only Normal Man in Baghdad,” p. 78.
} 
signaled removal from the corruption of commercialism and, thus, innocence. His antipathy for commercialism translated to a respect for sexual expression in the abstract. Defining the exact nature of sexuality was distracting to artistic and sensual merit—as was the masking slickness of newly produced and neatly composed clothing.

Critics struggled to categorize the eroticism of Jack Smith's work and “queer theater" in general. Brecht tried repeatedly to articulate the meaning and effects of queer theater, a more encompassing genre than that of Ridiculous, to which Smith's work, once again, was central to at the time. However, Brecht's assertion that "the queerness of queerness is that it is asexual" was facile in its dismissal of any eroticism not easily cast as homosexual or heterosexual. ${ }^{55}$ Susan Sontag, in defending Flaming Creatures agreed that it was a shame to miss the film's value by labeling it homosexual. "The truth is that Flaming Creatures is more about intersexuality than about homosexuality." 56

Smith argued that his own sexual orientation — whatever that may have beenwas not responsible for the qualities found in his art. ${ }^{57}$ Smith pronounced himself queer but was frequently obsessed with women and railed against "garden-variety homosexuals. ${ }^{, 58}$ His casual disdain for the mainstream gay community was reciprocated. When Flaming Creatures was confiscated and censured, gay rights organizations did not exactly rally around: the director of the Homosexual League of New York admitted he found Flaming Creatures, "long, disturbing and psychologically unpleasant. . . Why

\footnotetext{
${ }^{55}$ Brecht, Queer Theatre, p. 177n. Michael Moon notes that "erotic charges in a work like Flaming Creatures" move across "circuits of gender and sexual identity." See Moon, "Flaming Closets," p. 83.

${ }^{56}$ Susan Sontag, "Jack Smith's Flaming Creatures," in Against Interpretation and other essays, (New York: Farrar, Strauss \& Giroux, 1964), p. 230.

${ }^{57}$ Sonya L. Jones, Gay and Lesbian Literature Since World War II: History and Memory (Haworth Press, 1998), p. 18.

${ }^{58}$ Leffingwell, "The Only Normal Man in Baghdad," p. 71.
} 
don't the filmmakers produce an authentic film about a love affair or something between two boys which takes place in the contemporary homosexual setting?"59

Smith was more comfortable with public revilement than with success, especially financial. Filmmaker and writer Jonas Mekas built much of his career on top of his arrest and notoriety for persisting in showing Flaming Creatures as well as Jean Genet's banned film Un Chant d'Amour (1950). For the rest of his life, Smith castigated Mekas (or, as he called him, Uncle Fishhook) for profiting from others' art. ${ }^{60}$ Smith's art was against "the conspiracy," as he considered it, that enforced conformity through artists' reliance on a capitalist system. Smith "intended nothing less than the socialization of the function of art," and was dedicated to composing new art "from the trash heap of what he considered a bankrupt and puritanical culture." His views on the necessity for communal nonconformity made him dependent on others for collaborations, but his inflexible demands and eccentricities made him a difficult work associate. ${ }^{61}$

From railing against the "landlordism" that required he pay rent to a rigorous nobudget aesthetic to his art, Jack Smith's political views and aesthetic passions were of a piece. The use of secondhand materials in the film was absolute, form and function. Smith had the "aesthetic daring to use outdated film stock of dubious provenance to give his black and white images the flickering ethereality of a world half consumed in the heat of its desire." ${ }^{62}$ His devotion to discarded objects was intrinsic to his message of a free-

\footnotetext{
${ }^{59}$ Edward Leffingwell, “The Only Normal Man in Baghdad,” p. 78.

${ }^{60}$ Despite its controversy, Flaming Creatures did not launch Smith into a successful career in subversion. As Michael Moon remarks, Susan Sontag, through her published defense of the film in The Nation, perhaps became more "famous" for Flaming Creatures than did Smith: "For every person who actually saw Smith's film, perhaps a hundred know it only from Sontag's description of it." See Moon, A Small Boy and Others, pp. 77-78.

${ }^{61}$ Leffingwell, "The Only Normal Man in Bagdad," p. 70.

${ }^{62}$ Hoberman, "Sight and Sound," p. 4.
} 
form, uncapitalist artistic priority. Because the materials used were methodically stripped of any foregoing usefulness - "in demonic purity junk" - they isolated and amplified an ambiguous, humorously serious sentiment that described New York City's urban decay. Smith worked and lived with the trash generated by "the big city's desires.",63

New York City's influence mixed with that of old Hollywood. Smith's obsession with the sets and décor of 1930s and 1940s Hollywood B movies focused especially on any productions starring Maria Montez. "To admit of Maria Montez validities," Smith wrote, "would be to turn on to moldiness, glamourous rapture, schizophrenic delight, hopeless naivete, and flittering Technicolor trash!"64 Smith's fixation on Montez underlined the trash aesthetic extension of re-use from the physical incorporation of discarded goods to the resurrection of cast off themes and characters from art and film, a habit of queer theatre that became rather reductively known as "camp." As Susan Sontag points out in her assessment of camp, it is not merely a light, mocking sensibility but an expression of a denied critique of accepted ideals. ${ }^{65}$ Smith's work critiqued habits of newness and novelty, advocating for renovation and resurrection.

And Smith did turn people on to "flittering Technicolor trash," through his own art and by his participation in theatrical productions. Smith's many jobs included costume design for John Vaccaro's Play-house of the Ridiculous in the mid-1960s. When Ludlam

\footnotetext{
${ }^{63}$ Brecht, "The Sheer Beauty of Junk," 43. The alliance between "desire" and "longing" and discarded objects can be found in many sources. It is worthwhile to note that Susan Sontag, Smith's most famous contemporary defender, began her bestselling novel The Volcano Lover at the entrance of a flea market, where the narrator wishes to find something that speaks " $\mathrm{t}] \mathrm{o}$ my longings." After listing potential desiderata, the protagonist, before entering admits, "Desire leads me." See Sontag, The Volcano Lover: A Romance (New York: Doubleday, 1992), pp. 3-4. ${ }^{64}$ Jack Smith, "The Perfect Filmic Appositeness of Maria Montez," in Film Culture, 27 (Winter 1962-63), p. 28.

${ }^{65}$ Susan Sontag outlines the seminal course on the sensibility of camp in "Notes on 'Camp," in Sontag, Against Interpretation and Other Essays (New York: Farrar, Straus, \& Giroux, 1966; essay orig. publ. 1964), pp. 275-292.
} 
left the Play-House in 1968 and started the Ridiculous Theatrical Company, Smith followed him, helping to define and popularize camp performances. Sontag includes as one of her "[r]andom examples of items which are the canon of camp," 1920s women's clothing — feather boas, and beaded and fringed dresses. ${ }^{66}$ Smith favored the profligate use of boas and beads, as well as glitter, and he was expert at creating desired effects out of lesser materials. Ludlam attributed his theater's trash aesthetic to Jack Smith, who was "a genius at doing things for no money. Jack Smith could take people and objects that everyone else considered worthless and transform them into the most exotic creation." Following Smith's lead, the Ridiculous Theatrical Company immediately "threw out the idea of professionalism and cultivated something much more extreme than amateurism. Actors were chosen for their personalities, almost like 'found objects." "68 Ridiculous theater rhetoric came very close to sounding like Goodwill's founder Rev. Helms decades ago, when Helms claimed " $\mathrm{t}]$ he Goodwill Industries takes wasted things donated by the public and employs wasted men and women to bring both things and persons back to usefulness and well-being. ${ }^{, 69}$ The camp critique of novelty ended up sustaining early twentieth-century ideas about stewardship and reuse.

The Ridiculous Theatrical Company presented lavish, relatively unrehearsed productions for three years, all without any funding, only with volunteers and donated materials. The sets and costumes grew more "environmental," taking over the stage, depicting an entirely different, abstracted world, much as Smith strove to do with his

\footnotetext{
${ }^{66}$ Sontag, "Notes on 'Camp,"” p. 277.

${ }^{67}$ Steven Samuels, ed., Ridiculous Theatre: Scourge of Human Folly, The Essays and Opinions of Charles Ludlam (New York: Theatre Communications Group, Inc, 1992), p. 20.

${ }^{68}$ Samuels, Ridiculous Theatre, p. 17.

${ }^{69}$ Helms, Pioneering in Modern City Missions, (Boston: Morgan Memorial Printing Dept., 1944), pp. 71-72.
} 
loft — his stage and home. The stage became not just a setting for a play, but installation art in its own right. At the same time, the content became more experimental and surreal. Ludlam was accused of — or credited with, depending on the viewpoint — removing plot from drama. ${ }^{70}$

Ludlam fully embraced the use of secondhand goods for a time, even working at a secondhand store. He was a vocal advocate of cultural and material re-use in theater, referring to his company's productions as “ecological theater." After Smith quit, the Theatre continued to employ the trash aesthetic, partly with the help of Smith's ingénue, Mario Montez. Montez applied techniques learned from Smith to Ludlam's plays. The Ridiculous Theater's extravagant costumes emphasized the application of oftenscavenged sequins, baubles, glitter, bangles, and beads. Volunteers crafted lavish looks out of used clothing and found materials. ${ }^{71}$

Ludlam admired Smith's adept use of discards, but his own use of pre-owned theatrical props and costumes was based on necessity rather than a holistic principle of anticommercialism. Ludlam's and his associates' poverty was not elective; however, to some critics, lack of funds was "one of the company's greatest assets." When the production of Eunuchs of the Forbidden City scored a \$10,000 grant from the National Endowment for the Arts, supplemented by a more modest amount from the New York State Council on the Arts, their "look of tacky opulence" was comprised. According to at least one reviewer, "Money is endangering the Ridiculous Theatrical Company."72

\footnotetext{
${ }^{70}$ See Brecht, qtd in Samuels, Ridiculous Theatre, p. 20.

${ }^{71}$ Kaufman, Ridiculous!, p. 66.

${ }^{72}$ From Martin Gottfried, "Money is Endangering the Ridiculous Theatrical Company," Women's Daily Wear (April 10, 1972), p. 16, qtd in Kaufman, Ridiculous!, p. 160.
} 
What criticisms of Ludlam's new sets and costumes implicitly recognized was the centrality of the process of acquisition to the final effects of the trash aesthetic. Where the materials for Ridiculous performances came from defined and inspired its content, for clothing and sets every bit as much as for the old B movies or classical theatrical characters referenced in scripts. Jack Smith often said that the costume was the character. The actor only brings it to life. ${ }^{73}$ Ludlam recalled a beautiful gown found at a thrift store by actor Everett Quinton and bought for Ludlam. That gown, which Ludlam compared to a Charles James - an American designer most renowned in the immediate post-WWII years for his highly structured, lavish ball gowns - inspired the creation of the play Galas, based on the life of Maria Callas. ${ }^{74}$

Prewar surrealist artists, many of whose work inspired avant-garde artists in the 1960s, agreed that the acquisition of materials was part of art — not just part of the artistic process, but of the art itself. In the 1920s, the acknowledged founder of Surrealism, Andre Breton, articulated the importance of "found" objects and the act of their discovery. In his 1928 autobiographical work Nadja, Andre Breton described the chance encounter with a flea market object as an experience capable of "admitting me to an almost forbidden world of sudden parallels, petrifying coincidences, and reflexes particular to each individual, of harmonies struck as though on the piano, flashes of light that would make you see, really see." ${ }^{, 75}$ He stumbled upon one particular portal at Paris's marché aux puces upon glancing a brand-new copy of Rimbaud's Ouvres Complétes "lost in a tiny, wretched bin of rags, yellowed nineteenth-century photographs, worthless

\footnotetext{
${ }^{73}$ Hoberman, On Jack Smith's Flaming Creatures, p. 16.

${ }^{74}$ Samuels, Ridiculous Theatre, p. 116. For more on Charles James, see Richard Martin, Charles James (New York City: Assouline Press, 2006).

${ }^{75}$ André Breton, Nadja. Translated by Richard Howard (New York: Grove Press, Inc., 1960, originally pub. 1928), pp. 19
} 
books and iron spoons." According to Breton, the volume is striking only in the context of the worn and tired objects surrounding it and the conversation with the "cultivated" stallkeeper, the only so-designated revolutionary in Nadja. The Surrealist value of a thing depended on the circumstance of its discovery. ${ }^{76}$ Eliminating the setting of acquisition compromised inspiration. The easy purchase of mass-produced glitter and glamorous costuming for the Ridiculous Theater effectively denounced the troupe's trash aesthetic premise.

For Andre Breton and other of his contemporaries, flea markets, antique fairs, and junk shops were places of possibilities for 'sudden parallels.' The objects at such venues attracted Breton for the "désenchaînement" they represented, both economically and culturally. ${ }^{77}$ Désenchaînement literally translates to "unchained" in English; Breton used the word to signify personal emancipation. ${ }^{78}$ By virtue of context, or lack of context, secondhand goods were emancipated from prior cultural meaning and usefulness. For similar reasons, Max Ernst used material from Victorian magazines found in Hell's Kitchens' flea market stalls in New York City in the 1930s, around the same time Joseph Cornell plundered the rows for equipment to outfit his boxes. Joseph Cornell understood certain objects to be threads between vision and banality, wakefulness and dreaming-

\footnotetext{
${ }^{76}$ Breton, Nadja, pp. 52-53; Margaret Cohen, Profane Illumination: Walter Benjamin and the Paris of Surrealist Revolution (Berkeley, Los Angeles, London: University of California Press, 1993), 109; Rosalind Krauss, "The Photographic Conditions of Surrealism," October 19 (Winter 1981): 3-34.

${ }^{77}$ Breton, Nadja, p. 53; see also Catharine Conley, "Surrealism and Outsider Art: From the 'Automatic Message' to André Breton's Collection," Yale French Studies, 109, Surrealism and Its Others (2006): 129-143; and Franklin Rosemont, André Breton and the First Principles of Surrealism (London: Pluto Press, 1978).

${ }^{78}$ Pierre Taminiaux, The Paradox of Photography (New York: Editions Rodopi B.V., 2009), p. 90.
} 
vessels of otherworldly communication. ${ }^{79}$ The désenchaînement of gleaned goods, in Jack Smith's case, allowed for queer presentations of style and sexuality, depictions not necessarily "chained" to definable sexual preference.

Gleaning was intrinsic to the New York City avante-garde aesthetic on which Ridiculous was based. Irving Rosenthal, San Franciscan native, one-time editor of Chicago Review, sometimes beatnik, and close friend of Smith's (he even acted in Flaming Creatures), described the widespread cohesion of an anticommercial aesthetic in postwar New York City. According to Rosenthal, in the late 1950s, avant-garde performers and artists defined themselves against what they were not or did not need: Hollywood, the mass media, academic poets, and money. "We were really poor and it was alright to be poor. It was our aesthetic to use whatever was at hand. Everybody went out "junking." ${ }^{\circ 80}$ Via Rosenthal, that aesthetic arrived on the West Coast around the same time "hip consumerism" invaded Haight-Ashbury’s hippie community along with thousands of hippie migrants. In 1967, Rosenthal returned to his hometown San Francisco and took with him his anticapitalist politics, an avant-garde trash aesthetic, an 18-year-old named George Harris, Jr., and a whole room's worth of theatrical “drag," feather boas, petticoats, gowns, hats, and more. Most of these fabulous articles were byproducts of Jack Smith's perpetual gleaning. Rosenthal stored them under lock and key in a room of the commune he immediately formed. ${ }^{81}$

\footnotetext{
${ }^{79}$ M. E. Walick, Max Ernst and Alchemy: A Magician in Search of Myth (Texas: University of Texas, 2001), pp. 158-160; Diane Waldman, Joseph Cornell: Master of Dreams (New York: Abrams, Inc, 2002), pp. 11, 17.

${ }^{80}$ From an unpublished interview with Lawrence Rinder, June 22, 1996, qtd in Lawrence Rinder, "Anywhere Out of the World," in Leffingwell et al., ed, Flaming Creature, p. 143

${ }^{81}$ The genealogy of the Cockettes first performance's dragwear is recounted from a few sources. See for example, Benjamin Shepard, "Play as World-Making: From the Cockettes to the Germs, Gay Liberation to DIY Community Building," in Dan Berger, Ed. The Hidden 1970s: Histories of
} 


\section{Complete Sexual Anarchy: The Cockettes}

Once established in San Francisco, Harris renamed himself Hibiscus, grew out his hair and beard, pierced his nose and wore skirts "culled from garbage bags, remainder bins, thrift shops and leftover piles. ${ }^{92} \mathrm{He}$ lived with Rosenthal at the commune, and on New Year's Eve 1969, Hibiscus and a group of self-proclaimed "anarchists" wheedled the drag room key from its keeper-Rosenthal was out of town. Arrayed in their elaborate secondhand plunder, ten men, three women, and a baby ushered in the new decade on the stage of the Palace Theater in North Beach, California, cancan-dancing to the Rolling Stones. The reception was enthusiastic, and launched the newly christened Cockettes on a year and a half of fame. ${ }^{83}$

The Cockettes' debut performance was poetically timed, closing out a decade that, despite its initial conservatism, would be defined by war protests, sexual revolution, and a visual aesthetic inspired by psychedelic drug use and ushering in an era shaped by economic crisis, glam rock and disco, and gay liberation. George Lipsitz summarized John Street's analysis of the 1970s' supplanting of the previous decade as "[S]equins for beads, decadence for politics and open plagerism for originality." ${ }^{84}$ The Cockettes did not choose — one era did not oust the other: they pasted sequins onto their beads, their

Radicalism (New Brunswick: Rutgers University Press, 2010), p. 180. Allan Ginsberg, in a 1993 interview with Stephen Taylor traces his own "glamrock" persona back to Smith and Rosenthal, through his boyfriend Hibiscus's clothing, purloined from Rosenthal. See Jerome, Creating the World, p. 197.

${ }^{82}$ Shepard, "Play as World-Making, p. 180.

${ }^{83}$ See Shephard, "Play as World-Making," p. 181; Talbot, Season of the Witch, pp. 98-102. Details of the first show were also related by Rumi, interview with the author; and in Julia BryanWilson, "Grit and Glitter," Octopus (Vol. 4, Fall 2008), 19-30.

${ }^{84}$ See Lipsitz, "Who'll Stop the Rain?: Youth Culture, Rock 'n' Roll, and Social Crises," in David Farber, ed., The Sixties: From Memory to History (Chapel Hill: University of North Carolina Press, 1994), p. 18. 
decadence was often at least perceived as political, and by way of plagiarism—of musical numbers and of antiquated styles - they were wildly original. Their fantastical clothing and improvisational theater captured the cusp, exemplifying emerging ambiguities in sexuality, gender, and artistic performance but not displacing the psychedelicism of the 1960s.

Central to nearly every contemporary description of the troupe's outrageous style was their patched-together thrift-store look. ${ }^{85}$ An eclectic mélange of found materials shaped their style, and borrowed cultural references and parodies comprised the content of their shows. Clothes were central to the identities of the performers, who often dressed (and undressed) in life as on stage. Members of the troupe stole, bartered, bought, borrowed, and wheedled their way into the chaotic costumes. They combined glamour and the gutter, the east and the west, glitter and rags, elaborate layers and nudity, all in a single pose. Following Jack Smith's lead, they blurred lines between male and female and between everyday living and theatrical performance. ${ }^{86}$ John Waters described them as "hippie acid freak drag queens, which was new at the time... You couldn't tell if it was men, or women. It was straight people, too. It was complete sexual anarchy, which is always a wonderful thing." ${ }^{\circ 7}$ Figure 5.3. shows four original members of the Cockettes,

\footnotetext{
${ }^{85}$ See for example, Clay Geerdes, "The Cockettes," Door (Sept 29-Oct 13, 1971): 23-24; "Hibiscus and The Angels of Light," Good Times 4.32 (November 1971): 6-7; John Weiner, "Cockettes," Rags (August 1970); and Jon Stewart, "From the Cockettes with Love and Squalor," Ramparts (December 1971); "Les Cockettes de San Francisco," Rolling Stone 93 (October 14, 1971).

${ }^{86}$ Richard Ekins and Dave King describe the Cockettes as presaging “'transcending' gender stories that came to fruition in the mid-late 1990s." See Ekins and King, Transgender Phenomenon (London: Sage Publications, 2006), p. 191.

${ }^{87}$ John Waters qtd in Weber and Weissman, The Cockettes. For more about Waters relationship with the Cockettes, see Waters, Shock Value (New York City: Thunder Mouth Press, 1995), pp. 68-74.
} 
including Sweet Pam and Scrumbly Koldewyn (far right), whose subsequent marriage was featured in Rolling Stone magazine. ${ }^{88}$

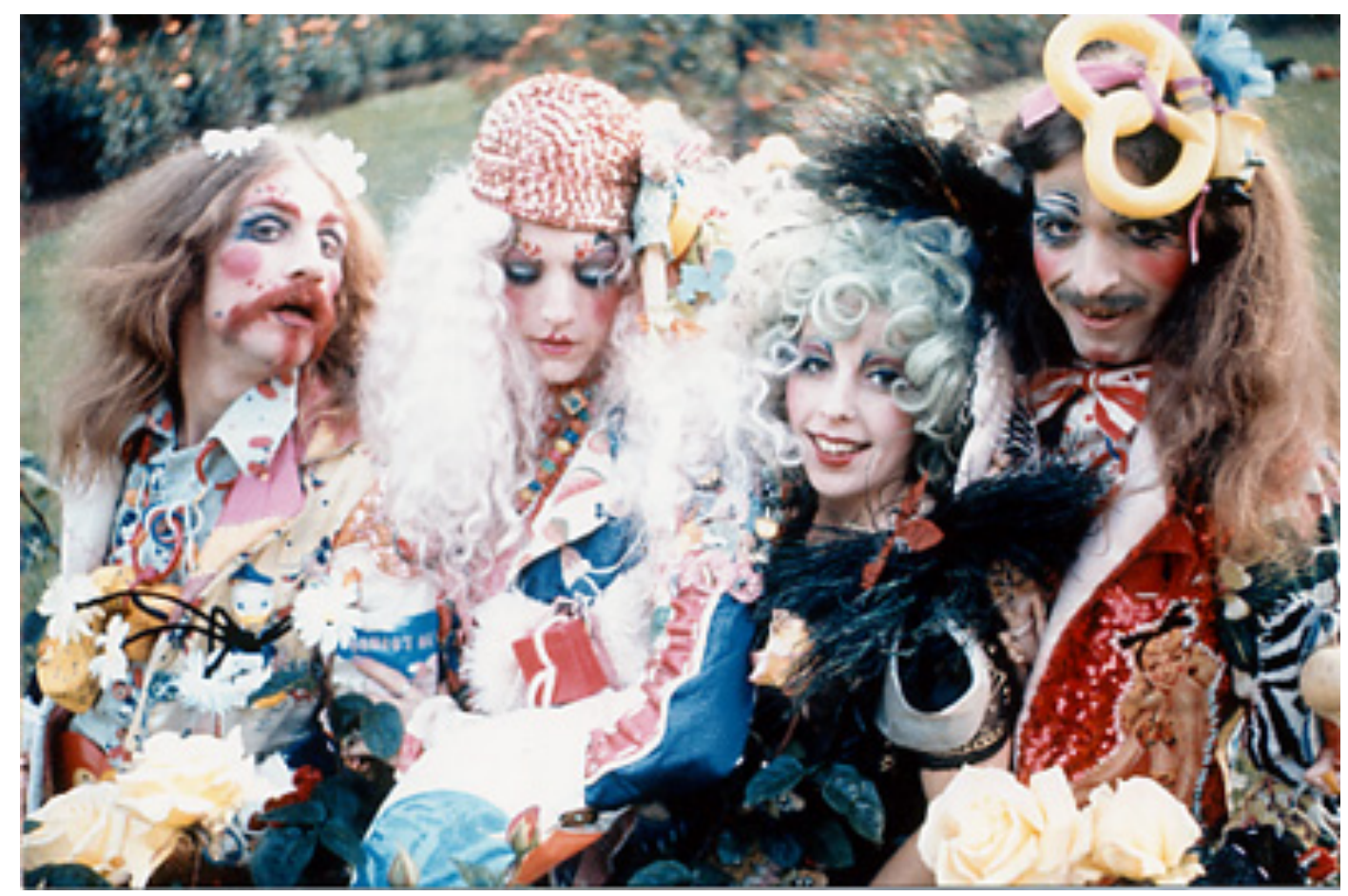

Fig 5.3. Four original members of the Cockettes. 1970. Photo courtesy of San Francisco's GLBT Society.

Hibiscus, the founder of the Cockettes, and Rosenthal's sometimes acolyte, combined the anticommercial aesthetic of New York City with Diggers-style principled anarchic anticapitalism and a San Francisco psychedelic sensibility. Upon his return to San Francisco, Rosenthal founded the Sutter/Scott Street Commune, better known simply as Kaliflower after the group's inter-communal free newsletter. Rosenthal intended Kaliflower to be a "publishing commune," as he wrote to Allan Ginsberg—a completely free, self-supporting publishing house not reigned in by any of the profit motives that

\footnotetext{
${ }^{88}$ Annie Leibovitz photographed the wedding. For further description, see Lake and Orloff, The Unsinkable Bambi Lake, p. 48; and Weber and Weissman, The Cockettes.
} 
drove Rosenthal to quit as editor of Chicago Review. ${ }^{89}$ Several of the members of the Cockettes came from Kaliflower and brought with them the commune's defining anticapitalist, anti-commercial ideology, principles other Cockettes did not fully embrace. ${ }^{90}$ Discord over whether or not to charge money for their performances was central to the rupture of the group a year later, when Hibiscus left to start San Francisco's Angels of Light Theater-strictly a free-theater production.

Overall, the thirteen or so original Cockettes had little in common aside from a love of drag. Drag referred to any elaborate accouterment, regardless of the wearer's gender or sexual predilections. A tricked-out, embroidered, and sequin-laden Victorian velvet skirt was drag whether worn by a man or "a biological girl." Clothes were central to the identities of the performers, who in Hibiscus's words desired to "perform unrelated to buying and selling and the man," a sentiment reflective of his anticommercial principles. ${ }^{91}$ Almost everything was secondhand. Acquisition was so important to the group that Fayette called shopping their "job." Renowned "Pope of Trash" filmmaker John Waters (who lived with Cockettes member Rumi Missabu) reported that, for the group, "going to thrift shops was a ritual. People practically chanted when they did it." Glitter — the promiscuous use of which Jack Smith is often given credit—was one of the only "new" things the group bought. ${ }^{92}$

\footnotetext{
${ }^{89}$ See Matthew Ross, “Coming Together: The Communal Option," in Chris Carlsson and Lisa Ruth Elliot, eds., Ten Years That Shook the City: San Francisco, 1968-1978 (San Francisco: City Lights Books, 2011), pp. 197-200.

90 Actually, many Cockettes members, including Jalala, Jet, Tahara, Ralph and Hibiscus, were kicked out of the commune, which did not allow external affiliations. Rumi Missabu, Interview with the authors, September 2010.

${ }^{91}$ Gregory Pickup, Pickup's Tricks, Unreleased film, 1973.

${ }^{92}$ Hauser, interview with the author. Waters qtd in Weber and Weissman, The Cockettes.
} 
Most of the Cockettes did not have an income but subsisted on some form of government aid — many were ajudged mentally disabled and awarded Aide to the Totally Disabled (ATD).$^{93}$ The Diggers free store and cheap thrift shops accounted for much of their raw material. Hibiscus, fellow Cockette Bambi Lake recounted, would "use his SSI check to buy ten bags of glitter and two expensive beaded vintage gowns at secondhand stores and then rip the gowns to shreds." ${ }^{94}$ Hibiscus described this sort of destructive transformation of materials in terms similar to those of Jack Smith, Charles Ludlam, and indeed, the founders of the Salvation Army and Goodwill Industries, but made it strictly personal. Hibiscus took advantage of the "waste of a culture" to craft a new identity, one that did not rely on standard interpretations of gender or sexuality. ${ }^{95}$

The "waste" Cockettes found determined details of their performances—which, in the first year, were all in San Francisco and mostly at the Palace. In 1970, the MGM studios had a giant auction at their Los Angeles studio, selling artifacts like July Garland's Wizard of $\mathrm{Oz}$ ruby slippers. ${ }^{96}$ While the Cockettes could not have afforded the A-list clothing, like the iconic green "Curtain Dress" worn by Vivian Leigh as Scarlett O'Hara, the Cockettes were invited to a solo shopping spree at a San Francisco warehouse stocked with B-movie and chorus clothing from 1930s-1950s Hollywoodperfect fodder for a trash aesthetic. Fayette credits the MGM sale with the elevation of the Cockettes performances, calling it "the magic potion." In fact, she laughingly swore

\footnotetext{
${ }^{93}$ John Waters and Rumi Missabu were roommates at this time and were among the few who could not get ATD. Rumi did not have a proper ID. Waters was told he was insane but not permanently. Rumi Missabu, interview with the author; John Waters in The Cockettes.

${ }_{94}^{94}$ Lake and Orloff, The Unsinkable Bambi Lake, p. 29.

${ }^{95}$ Benjamin Shepard, "Play as World-Making," p. 180.

${ }^{96}$ The auction was part of the studio changing hands, and in general, the decline of the old Hollywood studio system and the beginning of new Congomerates like Paramount. See Leonard Quart and Albert Auster, American Film and Society Since 1945 (Santa Barbara, California: Praeger, 2011), pp. 77-78.
} 
the sale was "the most significant thing to happen to the hippie culture."97 The warehouse sale coincided with the rise of the Cockettes' popularity, and the members were dazzled by the possibilities arrayed there. As Fayette put it, "It's like having a crush on someone when you're twelve and then getting to have sex with them when you're grown up."98 According to Fayette, the MGM sale affected everything from the Cockettes' stage aesthetic to the content of the plays. Because the costumes were made for black and white film, all the shades were soft and tonal. The colors and designs of costumes both softened and grew more elaborate after the sale, inspired by the theming, quality, and quantity of the Hollywood material. In addition to Smith's "flittering Technicolor trash," the Cockettes were steered toward lace and the muted tones of late-Edwardian filmswith an added layer of glitter and glitz, as represented by Hibiscus, in Figure 5.4. The items allowed members to play out "fantasies" about old movies. Even before his incarnation as Hibiscus, George Harris, Jr., decorated his room with images of 1940s movie icons torn from library books; he adapted his fantasies according to his material provisions. $^{99}$

\footnotetext{
${ }^{97}$ Hauser, interview with the author; Missabu, interview with the author.

${ }^{98}$ Hauser, interview with the author.

${ }^{99}$ Hauser, interview with the author; Shepard, "Play as World-Making," p. 180.
} 


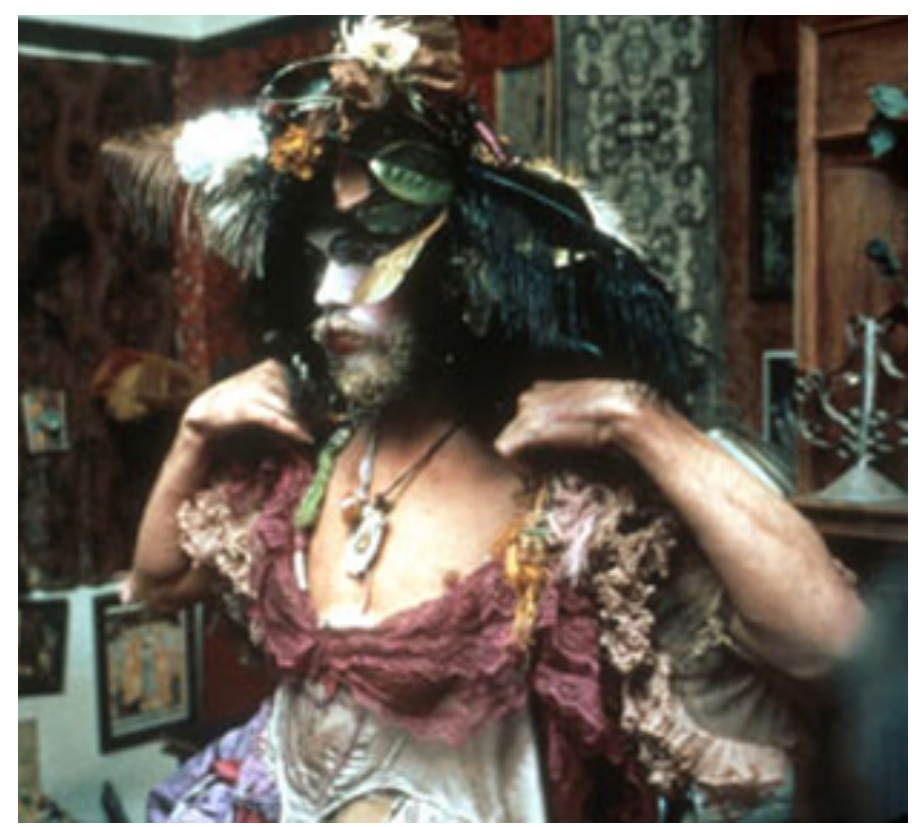

Figure 5.4. Hibiscus dressing to go onstage, circa 1970. Still shot from The Cockettes. Strand Releasing, 2002.

Once again, the thing about secondhand cloth products that makes some consumers squeamish is an assumption about the transference of something, whether tangible or not, from the clothing's previous wearer. In this case, that transference was positive: glamour, stardom, beauty. Slipping into Hollywood clothing allowed the performers "to be the fantasies." 100 As one 1971 profiler of the group agreed (though with a less than approving tone), "[e]ach [of the Cockettes] is the embodiment of a myth, a dream, a fantasy." 101

The lyrics and action of Cockettes' shows were sometimes written around a single fabulous costume (much like Ludlam's Galas), or an array of newly gleaned outfits. ${ }^{102}$

\footnotetext{
${ }^{100}$ Hauser, Interview with the author. Fashion theorist Elizabeth Wilson argues that critiques of fashion as "one example of a mass outbreak of inauthenticity," were based on the "utopias both of right an left, which were themselves fantasies, [and] implied an end to fantasy in the perfect world of the future." In this regard, the Cockettes were realists who understood the need for utopian representations. See Wilson, "Feminism and Fashion," in Adorned in Dreams: Fashion and Modernity (London and New York: I. B. Taurus), pp. 246-247.

${ }^{101}$ Barbara Falconer, "The Cockettes of San Francisco," Earth (October 1971). For similar references and examples, see also Gamson, The Fabulous Sylvester, p. 54; and Clay Geerdes, "The Cockettes," pp. 23-24.

102 Tent, Midnight At the Palace, p. 95.
} 
For example, the Cockettes shared a stage at the Palace Theater with the Peking Opera, who came to the China mainland a few times a year to perform. In November of 1970 , the opera left behind a huge, steamer trunk packed with costumes, which subsequently disappeared. Its contents soon reappeared on various Cockettes. Rumi was given a "gorgeous tangerine colored taffeta with beautiful orange sequins all over it with a headdress and everything."103 The costume was so strongly associated with its Peking Opera character that Rumi was identified as that character while wearing it, echoing Jack Smith's motto that the costume was the character and the actor only a vessel. ${ }^{104}$ The very next Cockettes performance was Pearls Over Shanghai, one of their more famous numbers (renditions of which are repeated to this day). With the Kabuki makeup, Geisha wigs and raunchy songs, many lyrics of which were an idea of broken Chinese-English, Pearls Over Shanghai was a tableau of Orientalist mockery, a parody of the source of their costumes. ${ }^{105}$

The Cockettes could not rely on opera costume trunks and movie studio divestments for all their wares, of course. Expert shopping skills earned the respect and loyalty of Cockettes members, and even secured membership to the group. Before heterosexual married couple Marshall and Diane joined, their shop, The Third-Hand

${ }^{103}$ Missabu, interview with the author.

${ }^{104}$ Missabu, interview with the author.

${ }^{105}$ As Sweet Pam recalled, public reception of Shanghai was not all enthusiastic, especially when they took the act to the streets. "Our forcing a drag-queen rendition of fake Oriental platitudes down throats of people trapped in their own apartments upset the locals, and they made their displeasure known.” Tent, Midnight at the Palace, p. 100. Since Edward Said's seminal work on the topic, many scholars have critiqued Western appropriation and interpretation of images and cultural ideas of the Orient. See Edward Said, Orientalism (New York: Vintage Books, 1979). Sheng-Mei Ma explores the relationship between American Orientalism and Asian American identity, including sexual and gender stereotypes in The Deathly Embrace: Orientalism and Asian American Identity (Minneapolis, MH: University of Minnesota Press, 2000). For a study contextualizing the Orientalist attitudes during the postwar years, see Christina Klein, Cold War Orientalism: Asia in the Middlebrow Imagination, 1945-1961 (Berkeley: University of California Press, 2003). 
Store, furnished the group with much of their elaborate garb. Sweet Pam, an original Cockette, worked at the Third-Hand Store in order to have first shot at the "vintage" goods. Sylvester James (who would go on to become one of the most famous Cockettes as Sylvester, "Queen of Disco") first attracted the attention of Reggie, another "chocolate Cockette" - as the few African-American participants called themselves - because of his beautifully androgynous appearance. They bonded by wandering the thrift stores of Haight-Ashbury, where Sylvester found everything he needed, a woman's suit, silk stockings, women's shoes, a woman's jacket, and a feathered hat, "and put it right on and just wore it in the street, brazen." Reggie thought, "That bitch can shop." ${ }^{106}$ Sylvester's raiment quickly impressed the other Cockettes immediately, too, almost as much his undeniable musical and performance talent.

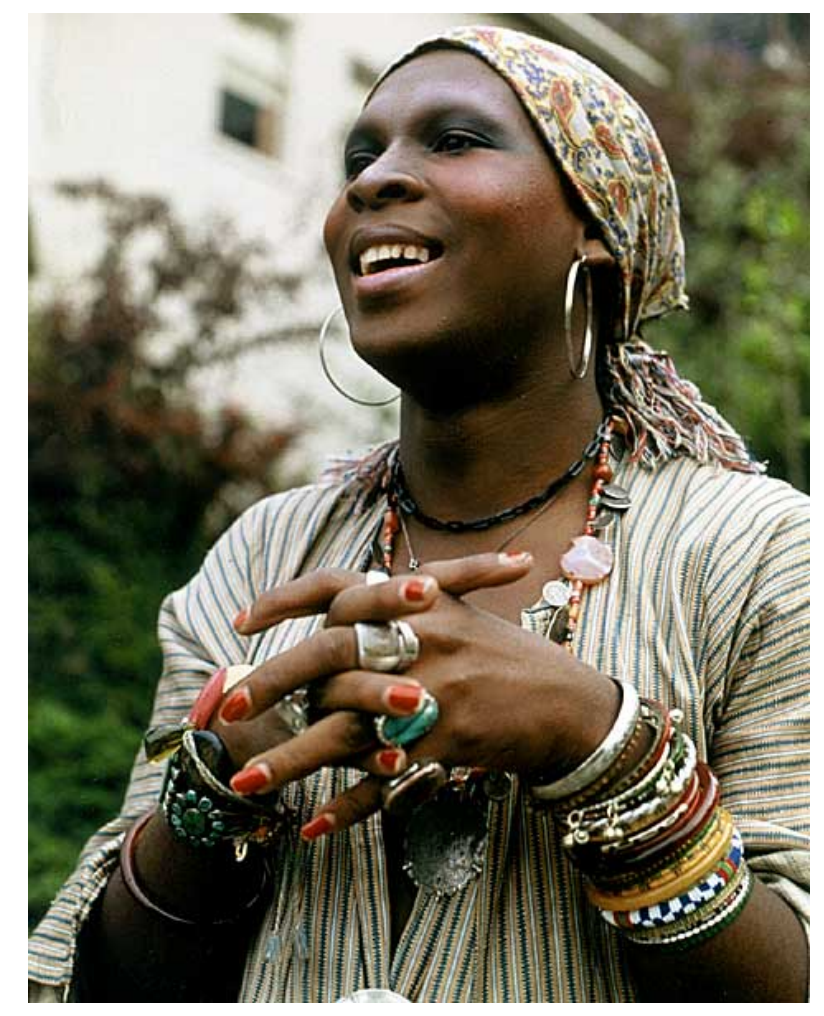

Figure 5.5. Sylvester James when he was with the Cockettes, 1970. Photo by Clay Geerdes.

${ }^{106}$ Gamson, The Fabulous Sylvester, pp. 44-45, 59. For more on Sylvester James' upbringing and career see also, Judith A. Peraino, Listening to the Sirens: Musical Technologies of Queer Identity from Homer to Hedwig (Berkeley: University of California Press, 2006), pp. 187-194. 
Sylvester proved to be the biggest star in the Cockettes, if never quite the biggest star of the Cockettes, at least not as long as Hibiscus was in charge. ${ }^{107}$ At the end of 1970, after Hibiscus left to form The Angels of Light, the Cockettes' much-anticipated New York City debut mostly tanked, but it did help make a star out of Sylvester. ${ }^{108}$ Several years later, Sylvester's 1978 disco hit You Make Me Feel (Mighty Real) established him as the first openly gay top-selling artist. The original Cockettes disbanded within a year after the New York debacle, but their aesthetic contributions did not end there. In addition to Sylvester's success, many members influenced 1970s popular culture from a number of positions. A later Cockettes member Divine became John Waters' acclaimed muse, staring in a string of aptly named "trash films" that very nearly took Ridiculous theater mainstream, including Hairspray (1988), which grossed $\$ 8$ million domestically. ${ }^{109}$ Other Cockettes continued to work with clothing for a living, becoming stylists and designers. After impersonating her, Rumi Missabu styled Tina Turner for a year and a half, and Fayette Hauser dressed her friend Bette Midler when Midler began her Vegas show. ${ }^{110}$ Bill Bowers dressed members of the New York Dolls, the Rolling Stones, Led Zeppelin, Alice Cooper, and Aerosmith. He also designed his own glam rock

\footnotetext{
${ }^{107}$ Joshua Gamson relates several clashes between Sylvester and Hibiscus, including an instance when Sylvester slapped Hibiscus for upstaging him in a performance. See Gamson, The Fabulous Sylvester, pp. 74-75.

${ }^{108}$ Though much media surrounding the New York City debut was negative, Maureen Orth produced a more measured account and description of the Cockettes performances, pointing to the overlooked avant-garde qualities. See Maureen Orth, "History of a Hype Worm in Big Apple," Village Voice (November 25, 1971): 5, 68.

${ }^{109}$ For more on John Waters personal life and film career, see Robert L. Pela, Filthy: The Weird World of John Waters (New York City: Alyson Books, 2002); James Egan has collected some of the many interview Waters has given in John Waters: Interviews (Jackson, Mississippi: University of Mississippi Press, 2011).

${ }^{110}$ Missabu, interview with the author; Hauser, interview with the author.
} 
wearables - his designs were featured in a 1971 issue of Italian Vogue, when his creations still relied on secondhand clothing that he altered. ${ }^{111}$

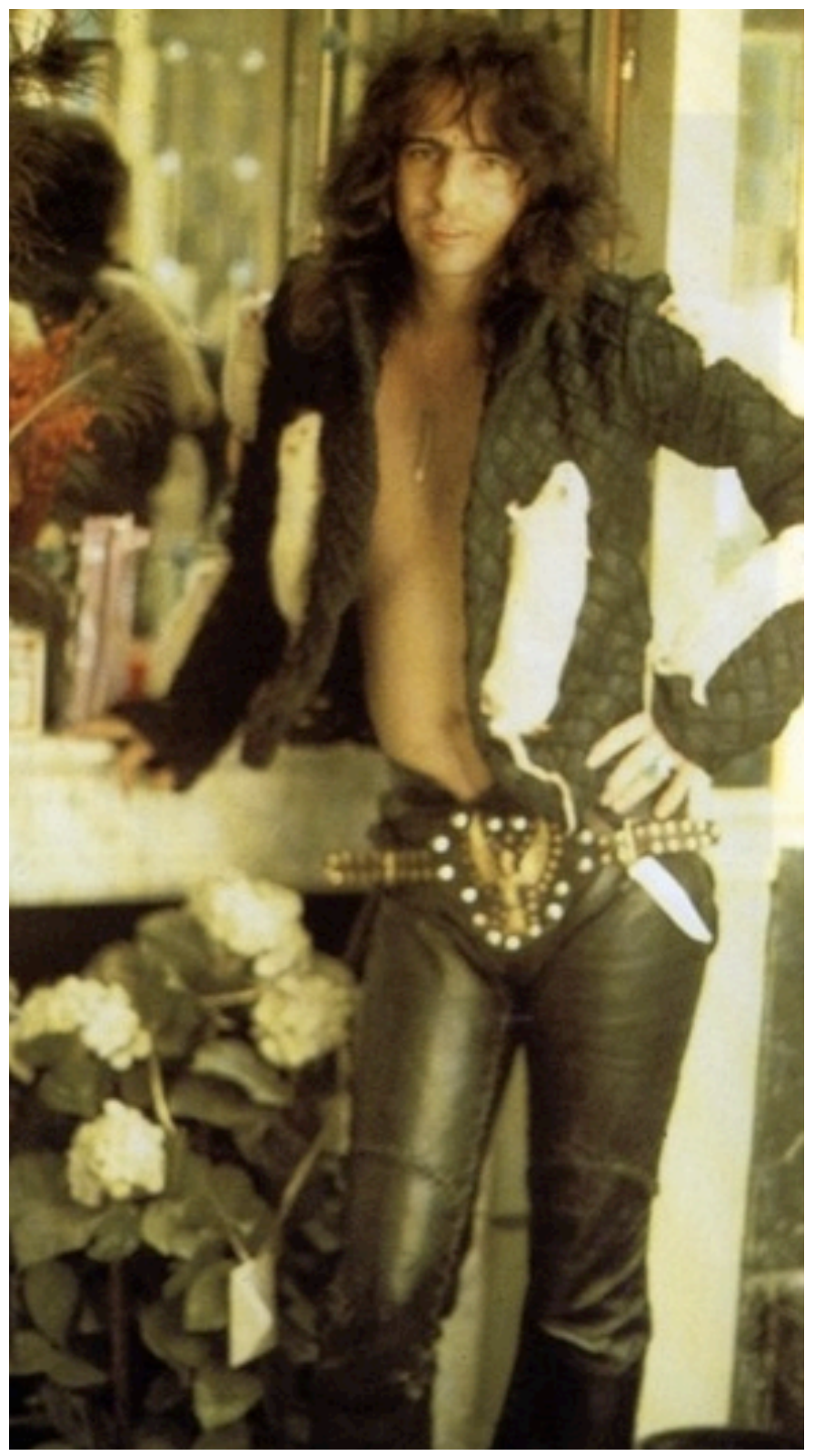

Fog 5.6. Alice Cooper wearing a Bill Bower design, circa 1973. Photo courtesy of Rumi Missabu.

In the brief eighteen months oo so of their original run, from the start of 1970 until the middle of 1971, the Cockettes' use of thrift-store goods and their trash-glamour

\footnotetext{
${ }^{111}$ See "New York: Ragazzi Che Vestono, Pop-Group," Italian L-Uomo Vogue (Feb-March 1973); see also Alexandra Jacopetti, Native Funk and Flash: An Emerging Folk Art (San Francisco: Scrimshaw Press, 1974); Missabu, interview with the author.
} 
aesthetic rooted in anti-capitalist sentiments profoundly shaped American glam. Beat poet (and one-time lover of Hibiscus) Allan Ginsberg claimed the Cockettes "affected the entire suburban culture" of the 1970s. "Kids who wanted some way to express difference from the homogenized television culture adopted the plumage" of the Cockettes. ${ }^{112}$ Eventually, the Cockettes commercialized a trash aesthetic forged by those with anticapitalist motivations, like Hibiscus and Jack Smith. Despite the apparent forfeiture of anticommercialsm, there was at least a retrospectively principled justification for the popular dissemination of a gender-transgressive trash aesthetic. As Ginsberg suggests, "The Cockettes were part of a large-scale spiritual liberation movement and reclamation of self from the homogenization of the military state. They were expressing themselves as actual people with their own natures and tendencies, rather than being ashamed — and doing it with humor."113

Political meaning was easy to attribute to the Cockettes, especially post-mortem. As Cockette John Rothermel said, "Since we were so open to interpretation, we were used by radical factions and distorted well beyond what our statement really was — that we were simply having a party." ${ }^{114}$ Members of the Cockettes disagreed whether they were a political group. Fayette said, for her it was about aesthetic development, not political claims. "Of course, it was political," fellow member Martin Worman said, "but no one among us verbalized it." ${ }^{115}$ The politics Worman references is not anticapitalist, Diggers-style hippie rhetoric, nor simply about sexual freedom. Rather, the bricollage

\footnotetext{
${ }^{112}$ Ginsberg qtd in conversation with author, in Thompson, "Children of Paradise," 449. Ginsberg performed with Hibiscus in his troupe Angels of Light, chanting to Blake's Songs of Innocence. Hibisbus claimed is was the poet's "first time . . .ever in drag." See "Hibiscus \& the Angels of Light," Good Times 4.32 (Nov 12, 1971), p. 6.

${ }^{113}$ Thompson, "Children of Paradise," 449.

114 Thompson, "Children of Paradise," 449.

115 Thompson, "Children of Paradise," 449.
} 
aesthetic was about the exploding of a complexity of postwar myths. Myths of glamour and romance, success, and, importantly, nostalgia. "Nostalgia became an insidious tool used my mass marketeers to cover up shortages of spirit, imagination and raw material." Worman claimed. "But in our wake, old clothes and old songs, became ends in themselves." ${ }^{, 16}$ While regional malls and department stores categorized and segmented fashion by brand, sex, style, and cost, secondhand clothing lacked those barriers, opening their use up to playful and deviant style interpretations that only superficially—and often ironically—acknowledged the materials' original contextualization.

By the time of the Cockettes New York debut Hibiscus had formed a new free theater troupe, the Angels of Light. He held fast to his ideology of "free, but steadfastly refused to be drafted into political causes, especially equality movements. In response to a question about what he thinks of "women's liberation," Hibiscus simply reported an incident about a women's group "attacking" a show with the Angels of Light—-the details were fuzzy, as Hibiscus admitted to being very drunk. Similarly, when asked about gay liberation, Hibiscus responded vaguely that everybody should love each other. "As for Gay Liberation, I wouldn't be thinking of pure gay." 117 When with the Angels of Light, his only requirement was that "there is no admission. We're just going to perform in our free caberet."

Hibiscus masculinized drag; he openly wanted to be a man who could borrow from the mythical glamour of women Hollywood starlets' appearances in order not to dampen but actually to emphasize aggressive masculinity. He scoffed when asked if he wanted to be a woman, and pointed to the florid dress of men in Bali as being

\footnotetext{
${ }_{116}^{116}$ Mark Thompson, "Children of Paradise," 449.

117 "Hibiscus and the Angels of Light," p. 6.
} 
representative of the height of masculinity. In 1974, the lingering memory of the Cockettes inspired the word "genderfuck," coined to refer to a conscious effort to mix up, mock, or "fuck with" gender identity, gender roles, and gender appearance. ${ }^{118}$ Technically, men or women could participate in this transgressive practice, but invariably, examples of genderfuck were men, usually "glitter boys" with sparkling beards, hairy legs under miniskirts, or gowns torn to artfully frame penises. The gender radicality of the Cockettes themselves was not that they were a gay performance troop, as they are too often recalled as, but that its members included straight and bisexual men, women, and children. Indeed, the inclusion of woman — who might appear on stage in elaborate gowns or tuxedoes—-determined the group's genderfuck identity as much as any individual example of male appearance. Female Cockettes most often dressed as female characters, but as Dusty Dawn said, "If I want to be Hamlet onstage, why should someone tell me I can't be just because I don't have a joint hanging out?" 119 But despite the group's heterogeneous make-up, the flamboyant men were the undisputed stars and the leaders; they were the characters most admired and most reviled.

\section{The Boyfriend Look: Patti Smith and Annie Hall}

Conversely, the public reception and descriptions of women wearing men's clothing connoted far less sexual transgression than that of their male counterparts. In the 1970s, the fashion industry dubbed the growing practice of women wearing male clothing

\footnotetext{
${ }^{118}$ See Lonc, "Genderfuck and Its Delights,", 223-336. See also, Bryan-Wilson, "Grit and Glitter," 19-30.

${ }^{119}$ Clay Geerdes, “The Cockettes," 23.
} 
items, "the boyfriend look," a term that periodically recirculates still. ${ }^{120}$ The label boyfriend look recalled the 1950s fashion of wearing a boy's varsity jacket as a signal of intimacy, a public declaration of "going steady."121 In 1977, Diane Keaton appeared as Woody Allen's title star in Annie Hall, providing a popular image of a sweet, nervous, gaminely attractive woman quirkily dressed in men's clothing. Most of Keaton's clothing in the film, from ties to slacks to bowler hats, and shoes, is men's clothing-yet no one perceived the presentation as transgressive enough to qualify as genderfuck. ${ }^{122}$ Outsized slacks and floppy ties and hats emphasized Keaton's petiteness, underlining her femininity in converse correlation to how Hibiscus's torn gowns showcased masculine attributes. Whereas Hibiscus often looked as though his feminine apparel was unable to contain his male body's strength, Keaton's Chaplinesque wardrobe sometimes threatens to overwhelm and eliminate the appearance of her body, which is encased as thoroughly as Jack Smith's photographic Eve. Keaton's dress is hyper-modest (as befits her character's sexual anxieties), while Hibiscus revels in lascivious display.

But before Annie Hall won four Oscars and made Woody Allen even more of a household name, there were other, less submissive examples of female genderfuck using secondhand clothes. Poet, songwriter, "Godmother of punk," and fashion icon Patti Smith is frequently credited with establishing a vein of modern female androgynous style, a kind of post-war, thrift-store Marlene Dietrich, fashionably fey and carelessly stylish.

\footnotetext{
${ }^{120}$ According to James Sullivan, members of the jeans industry dubbed women wearing men's jeans "the boyfriend look" in the early 1970s. See Sullivan, Jeans (New York City: Gotham Books, 2006), p. 67.

${ }^{121}$ Though visible signs of "going steady" varied in the 1950s, the boy giving the girl something of his to wear - class ring, letter sweater, varsity jacket - was a common practice. For more on these and other commodity exchanges as part of dating rituals of the 1950s, see Beth L. Bailey, From Front Porch to Back Seat: Courtship in Twentieth Century (Baltimore, MD: The Johns Hopkins University Press, 1998), pp. 48-55.

122 Allen, Annie Hall.
} 
Smith straddles ambiguous territory in regards to her appropriation of male garments. ${ }^{123}$ One fashion history referring to her as "a rangy, disheveled gamine channeling Rimbaud and Baudelaire." ${ }^{\prime 24}$ Smith was also often claimed by feminists, who read her rough-hewn music and adaptation of thrift-store men's clothing as a proclamation of feminine liberation, despite Smith's repeated denouncements of movement affiliation. In a 1976 interview with Penthouse, Smith vigorously denied a role in women's liberation, saying "Whenever I'm linked to a movement, it pisses me off." Smith continued, "A word like Ms is really bullshit. . these assholes take the only fuckin' vowel out of the word Miss. So what do they have left? Ms. It sounds like a sick bumblebee, it sounds frigid. I mean, who the hell would ever want to stick his hand up the dress of somebody calling herself something like Ms? ${ }^{125}$ With her sexually blunt language, casual posturing, and masculine style, Smith's persona was that of "one of the guys," rather than an empowered woman.

For Jack Smith, Maria Montez was his sole stylistic inspiration, his icon of performance perfection. In comparison, Patti Smith had a whole legion of male influences, men she admitted fantasizing about. Her famous, instantly androgynizing hair cut was inspired by Keith Richards, and she copied much of her attitude, persona, and even walk from Bob Dylan, about whom she thought of so much at one point that, in her words, "It was as if he had been my boyfriend." ${ }^{126}$ In Figure 5.7, Smith passes as Dylan

\footnotetext{
${ }^{123}$ Patti Smith is often credited as a "fashion muse" for both fans and designers. Avant-garde clothing designer Ann Dermeulemeester, for example, credits Smith as a major inspiration for her mostly black, goth-inflected designs. See Valerie Steele, The Black Dress (New York: HarperCollins, 2007).

${ }^{124}$ See Alicia Kennedy and Emily Banis Stoehler with Jay Calderin, Fashion Design, Referenced: A Visual Guide to the History, Language \& Practice of Fashion (Rockport Publishers, 2013), 283.

${ }^{125}$ Nick Tosches, "Patti Smith," The Nick Tosches Reader, (New York: Da Capo Press Books, 2000), 70 .

${ }^{126}$ Tosches, "Patti Smith," 78.
} 
simply by placing a magazine cut-out of his face in front of her own. As she often did with her intellectual "crushes," Smith had no trouble seeing herself as becoming her own object of desire.

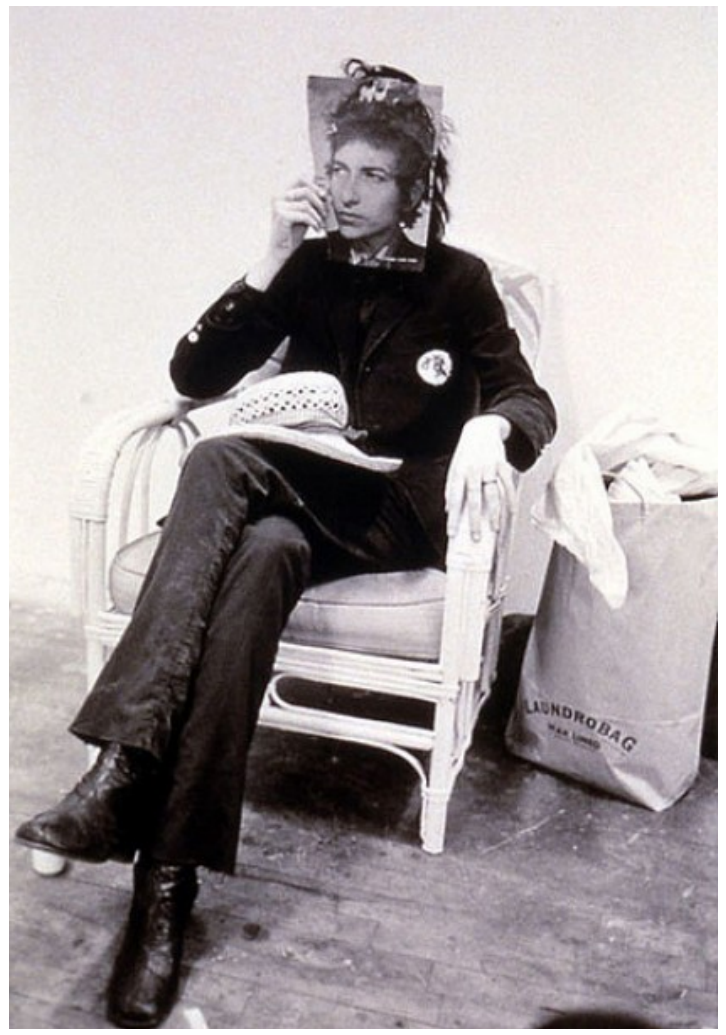

Fig 5.7. Patti Smith as Bob Dylan. Photograph by Judy Linn, c. 1970. Reprinted in Judy Linn, Patti Smith, 1969-1976 (New York: Abrams Image, 2013).

Consistently, her admiration and emulation of male artists was underscored by a kind of self-reflexive sexual desire. She repeatedly said of her teenaged obsession with the poet Arthur Rimbaud that (like Dylan), "he was like my boyfriend.” Smith's ode to him, "dream of rimbaud" is rife with violently sexual language. Her desire is aggressive; she is the initial seducer: "he who hesitates is mine. we're on the bed. I have a knife to his throat." 127 The narrator then drops the knife and gives in to the affair. The last line, "total surrender," applies to both Rimbaud and Smith, as they become one entity. ${ }^{128}$

\footnotetext{
${ }^{127}$ Nick Johnstone, Patti Smith: A Biography (Omnibus Press, 1997), 29; Patti Smith, "dream of rimbaud," Early Work, 1970-1979 (New York: W. W. Norton \& Company, 1994), 42-43.

${ }^{128}$ Smith, "dream of rimbaud," 43.
} 
Clothing's proximity to the wearer's flesh gives used clothes excellent potential as "precipitates of desire," as Breton called special found objects. ${ }^{129}$ Smith, when investing in secondhand men's clothing, imagined a sartorial transference of masculine power-an erotic exchange. She also saw certain clothes as badges of membership to a sort of all-boys' creative genius club in the male Romantic tradition. Smith imagined proximity to masculine style markets served as a badge of creative membership, and her rejection of female apparel often seemed intellectual. In her 1967 poem "Female," Smith expressed her discomfort with femininity and a related "phallic identity," ultimately expressed in clothing choice: "female. feel male. Ever since I felt the need to/ choose I'd choose male. I felt boy rythums when I/ was in knee pants. So I stayed in pants. "130

In her college days, she "searched for greatcoats in thrift stores like those worn by Oscar Wilde and Baudelaire."131 Just like the main character, Zane, in Burning Questions, a teenaged Patti Smith held Joan of Arc to be a role model—Joan of Arc, an icon of feminine strength and beauty fortified by the guise of masculinity. In May 1967, Smith travelled to Philadelphia to visit the Joan of Arc statue near the Museum of Art. To the baby she had just surrendered to more capable care and to the maiden warrior, Smith vowed to make something of herself. Smith recalls, in the same rhetorical breath as that vow, buying a long gray raincoat at a Goodwill store in Camden, New Jersey, on her way home. ${ }^{132}$ The purchase, a manifestation of her vow, marked a turning point for Smith.

\footnotetext{
${ }^{129}$ Breton, Nadja, 24.

${ }^{130}$ Philip Shaw offers a Lacanian reading of Smith's work and her expressions of "phallic identity." See Shaw, Patti Smith's Horses (New York City: The Continuum International Publishing Group, 2008). See also Patricia Morrisroe, Mapplethorpe: a Biography (New York City: Random Books, 1995), pp. 49-50.

131 Patti Smith, Just Kids, (New York: HarperCollins Publishers, 2010), 20.

${ }^{132}$ Smith, Just Kids, 29.
} 
The coat traveled with her to New York City, where she used it as a blanket sleeping in the park. When Smith wondered why a homeless man helped her find food and rest, Smith concluded that it was because they both wore "long coats in July, the brotherhood of La Boheme." By echoing Champfleury 1855 assessment of the impoverished affects of painters - and by running to New York City_-Smith joined over a century's worth of aspiring bohemians.

She slept on the coat at the bookstore where she got her first New York City job, and she wore it when she first met the future famed photographer Robert Mapplethorpe. Mapplethorpe's and Smith's relationship was mutually enacted genderfuck. They became each other, eliding and erasing markers of clear femininity or masculinity. They were exactly the same age, had similar backgrounds; Mapplethorpe's biographer agrees that he found in Smith "a doppelganger." 133 Smith and Mapplethorpe bonded and expanded their creative outlook scouring the same Bowery thrift shops and the same flea markets that inspired Breton, Cornell, and Ernst several decades prior. They swapped styles — with Mapplethorpe often advising Smith—and shared secondhand clothing. ${ }^{134}$

\footnotetext{
${ }^{133}$ See Morrisroe, Mapplethorpe, p.48.

${ }^{134}$ Smith, Just Kids, 225.
} 
Fig. 5.8. Smith and Mapplethorpe pose, androgynous mirror images, wearing the same expressions.

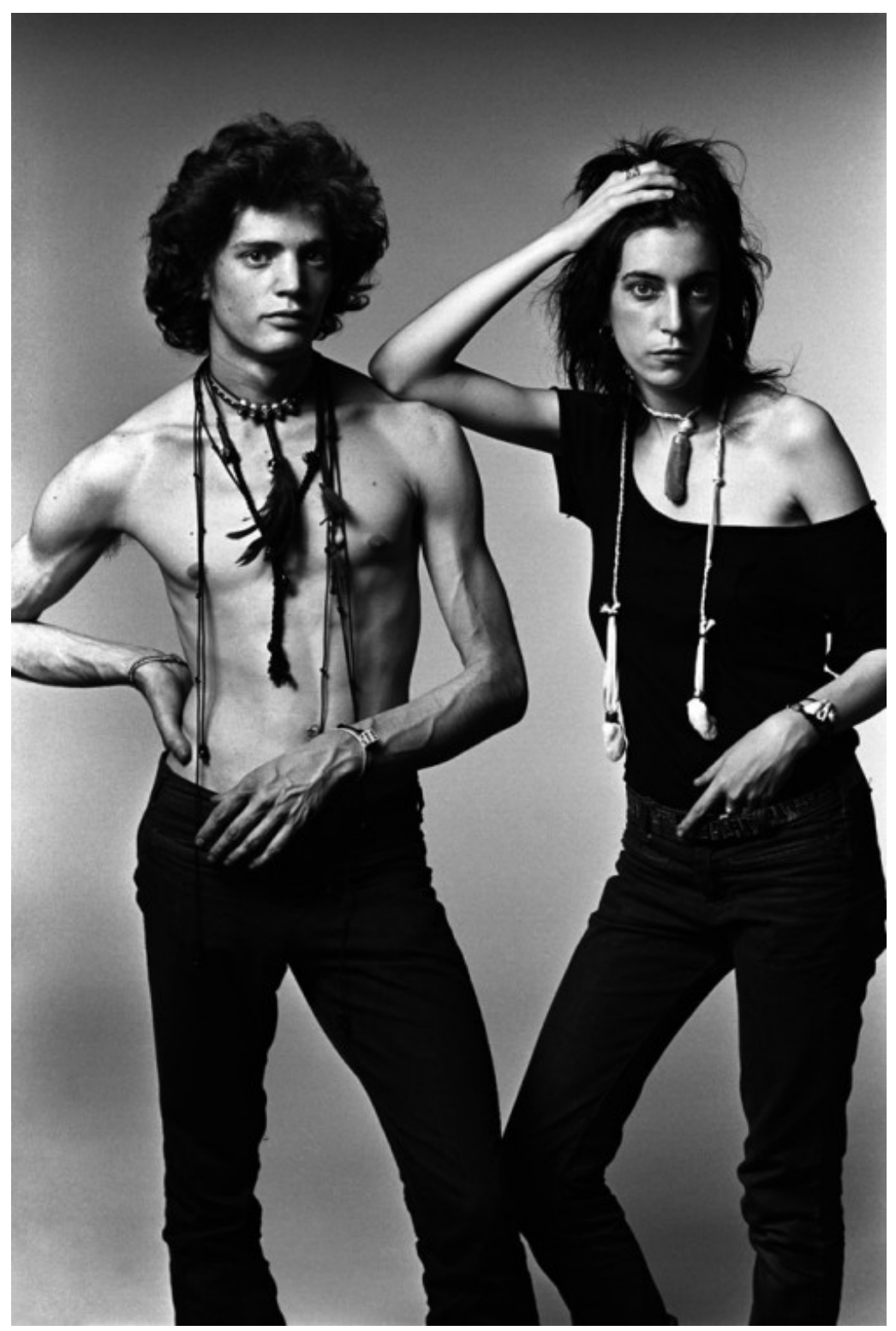

Perhaps the most famous image of Patti Smith was taken for the cover for her 1975 album debut album Horses by Mapplethorpe. As often happened to Smith, people appropriated the image as an icon of feminism—or even post-feminism. Camille Paglia said of the picture, it "immediately went up on my wall, as if it were a holy icon. It symbolised for me not only women's new liberation but the fusion of high art and popular 
culture." ${ }^{135}$ And as usual, Smith disputed such interpretations, pleading ignorance and poverty were responsible for the accidentally dissident picture. "I wasn't thinking I was going to break any boundaries. I just like dressing like Baudelaire," she said, once again portraying her impulses as purely artistic, unsullied by political inclination and inspired, if anything by a lustful, imagined camaraderie with male idols. ${ }^{136}$

The photo is a map of Smith's many and often sexually charged, masculine influences. While Paglia acknowledges this "homage to her major male progenitors," she overlooks the nature of those relationships broadcast through Smith's stance, her glance, and definitely, elements of her outfit. Patti Smith's androgyny communicated heterosexual desire. Sometimes her style attracted men, who like Mapplethorpe, desired masculine beauty (Allan Ginsberg once mistook her for a "very pretty boy"), but this should not be misread as non-heterosexual, or even, as Paglia asserts, as defying the "rules of femininity." ${ }^{137}$ Smith's attraction to masculine style was at root, narcissistic and self-referential, like her relationship with Mapplethorpe. She imagined herself as male, so she was attracted to men (or perhaps, since she was attracted to men, she imagined herself as male). Instead of trying to attract a mate, she dressed to attract herself.

Mapplethorpe took the photo. Smith confesses she never sees just herself in this photo, but the both of them - another instance of mirroring or absorbing a male interest, like in her Rimbaud poem. Her attraction to Mappelthorpe resonates in her expression's familiarity and tenderness. In her account of the photo, Mapplethorpe's biographer writes that writes that Smith "had a mental image of the portrait, in which she would blend

\footnotetext{
${ }^{135}$ Camille Paglia, "What's in a Picture," Civilizations (Dec. 96/Jan 97).

${ }^{136}$ Michael Bracewell, "Woman as Warrier," Guardian Weekend (June 22, 1996); Dave Thompson, Dancing Barefoot: The Patti Smith Story, (Chicago: Chicago Review Press, 2011), 121.

${ }^{137}$ Paglia, "What's in a Picture?"
} 
together Rimbaud, Baudelaire, Frank Sinatra, and Jean-Luc Godard to create a French Symbolist-Las Vegas-Nouvelle Vague persona—but she knew better than to explain any of this to Mapplethorpe."138 Even as subject, Smith directs the photographer, and so elides their roles.

When preparing for this shot, Mapplethorpe requested she doff her coat, exposing the stark whiteness of her man's button-up shirt. Smith agreed, flinging the coat over her shoulder in a very Frank Sinatra-ish way. A plain white shirt was already a signature element of Smith's wardrobe, whether button-up or a plain T-shirt. This particular men's white dress shirt Smith recalls having bought at the Salvation Army on the Bowery, one among a stack purchased. She chose to wear the one she did for the photo because it reminded her of "a Brassaï shot of Jean Genet." The cut sleeves even mirrored the length of Genet's rolled sleeves in Figure 5.9. By envisioning her shirt as part of this photo, Smith transposes her relationship with Mapplethorpe onto the dynamic between the famous Hungarian photographer, Brassaï, and his friend Genet, wherein she becomes the thief turned author. Brassaï's portraits of Genet show a naked vulnerability on the author's face, as seen in Fig. 5.9 despite his relaxed, hands-in-pockets posture. Brassaï, as a friend and fellow artist, reportedly disallowed for Genet's habitual affectations, which may account for the striking simplicity of the shot. ${ }^{139}$ Interestingly, then, Smith, in her imitation, is affecting disaffection, while also paralleling the photograph/subject relationship.

The monogram on the shirt, RV, perfected it for Smith, who imagined it was once worn by Roger Vadim, director of Barbarella, a 1968 futuristic flick about a scantily

\footnotetext{
${ }^{138}$ Morrisroe, Mapplethorpe: A Biography, 159.

${ }^{139}$ For more on the friendship between Jean Genet and Brassaï, see Jeremy Reed, Jean Genet: Born to Lose (London: Creation Books, 2005), esp. p. 138.
} 
clad, hypersexual women tasked with saving the world—played by Vadim's then-wife Jane Fonda. ${ }^{140}$ Feminist film critic Molly Haskell called Vadim a "Svengali," attributing Fonda's carnality in the film to his portrayal. ${ }^{141}$ In this permutation, Smith takes the directorial seat, underlining the narcissism of her androgyny, and the fact that, as Morrisroe points out, Smith plotted the photo while seeming to take direction from Mapplethorpe. At the same time, she is also the hyper-carnal subject, Barbarella.

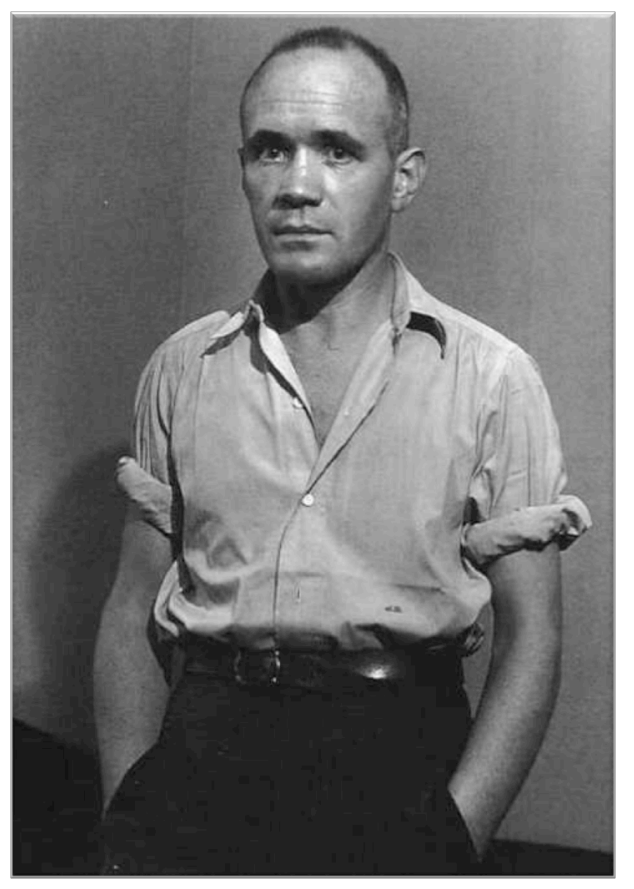

Fig. 5.9. Jean Genet. Photograph by Brassaï, Paris, 1947.

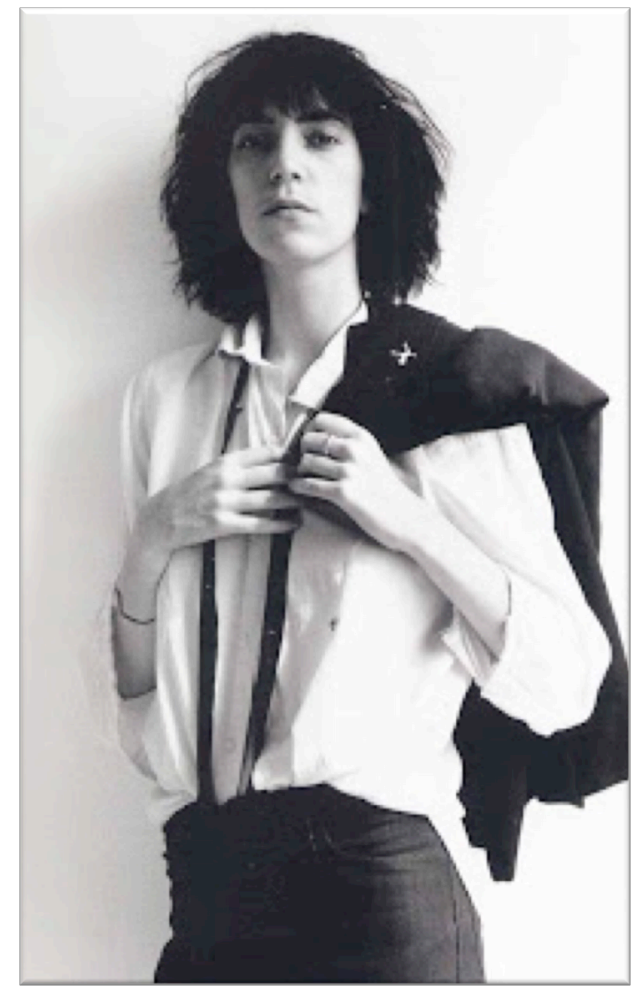

Fig. 5.10. Patti Smith, posing for the Wover of her album Horses. Photograph by Robert Mapplethorpe. New York

City, 1975.

\footnotetext{
${ }^{140}$ Vadim persuaded Fonda to star in Barbarella. She reportedly disliked the character and saw the film as misogynistic. See Patricia Bosworth, Jane Fonda: The Private Life of a Public Woman (New York City: Houghton Mifflin, 2011), p. 272.

${ }^{141}$ Molly Haskell qtd in Bosworth, Jane Fonda, p. 271. See also Marie Lathers, Space Oddities: Women and Outer Space in Popular Film and Culture, 1960-2000 (New York City: Continuum International Publishing Group, 2010).
} 
hile the punk aesthetic and lifestyle provided women with a powerfully antiestablishment aesthetic concurrent with second-wave feminism, the descriptive term that emerged in the 1970s to describe female cross dressing, "the boyfriend look," had a commercial resonance that also defused potential deviance. Calling the style "the boyfriend look" reassured an anxious public that the cross-dressing female was unquestionably heterosexual. Power gained through association with masculine abilities or talents was part of a long-established sexual economy. Patti Smith did not seek to repudiate that assumption, but rather, sought to play all the parts, to take the role of her own seducer and her own inspiration, as well as the submissive acolyte. Her complicated array of cultural identifications demanded the cultivation of an appearance that balanced heightened sensuality and self-regard, heterosexuality, and a catalog of male intellectual influences. Using secondhand materials, Smith was able to accommodate her wardrobe demands and financial limitations to set a new, oblique standard for female gender fuck.

\section{Conclusion}

By the 1960s, America's firsthand commercial zones were categorized and organized for greater consumer ease and convenience. These systems, however expedient, acted as style directives, separating male and female, youth and adult, rich and poor. At the same time, various types of secondhand outlets multiplied rapidly, and while chain thrift stores such as Goodwill also tried to facilitate consumer convenience by segmenting apparel, used goods commerce remained comparatively unlabeled and enormously accessible. In offering a greater variety of goods at usually lower prices, alternative consumer outlets like flea markets, junk shops, thrift stores, and garage sales 
attracted a growing minority of excluded shoppers who did not wish to conform their style to the sections at department stores.

The postwar rise of secondhand consumerism coincided with the political intensification of drag, the public presentation of queer identities, and the disruption of definitions of gender. Secondhand materials, including discarded abstract ideas, theatrical characters, literary themes, and clothing and other physical goods, were intrinsic to camp sensibilities crafted as critiques of novelty and corporate capitalism. The liminal state of discarded items, materials freed of intended use and disconnected from capitalist streams of exchange - what Andre Breton called the désenchaînement of pre-owned goodsinvited artistic experimentation. Queer presentations of style and sexuality, like those of Jack Smith and Patti Smith, depicted identities not necessarily "chained" to easily definable sexualities. Queer styles were fueled by the inherent flexibility of secondhand commerce. 


\section{Conclusion}

"Grunge is nothing more than the way we dress when we have no money."1

Jean-Paul Gaultier

In the early 1990s, Nirvana's leading man Kurt Cobain performed a variation on the Cockettes' thrift-store-styled genderfuck by donning vintage floral dresses with unwashed hair and dirty hiking boots (see fig. 6.1). Cobain, along with other "grunge" stars like Pearl Jam's Eddie Veder and Riot Grrrls like Bikini Kill's Kathleen Hanna, gained the loyal emulation of thousands of teenage followers. The popularity of the grunge look led to a spike in the sale of certain clothing, from L.L. Beans' flannel shirts to a broad array of thrift-store duds, things fashionably out-of-date and carefully uncleanseeming. ${ }^{2}$ At almost the very same time, Cobain's specific style's influence helped elevate major fashion designers like Marc Jacobs and Anna Sui-Sui's1994 line featured a series of floral babydoll dresses for both men and women - to international status. ${ }^{3}$

\footnotetext{
${ }^{1}$ Katherine Marin, "Runway Report,” Vogue (July 1993).

2 Timberland's stock doubled in 1991. See Rick Marin, "Grunge: A Success Story," The New York Times (November 15, 1992), V1.

${ }^{3}$ See Andrew Bolton, Anna Sui (San Francisco: Chronicle Books, 2010), p.53
} 
Fig. 6.1. Kurt Cobain in a vintage floral dress.

Amherst, MA, April 27, 1990. Photo via Malibu PR Gal.

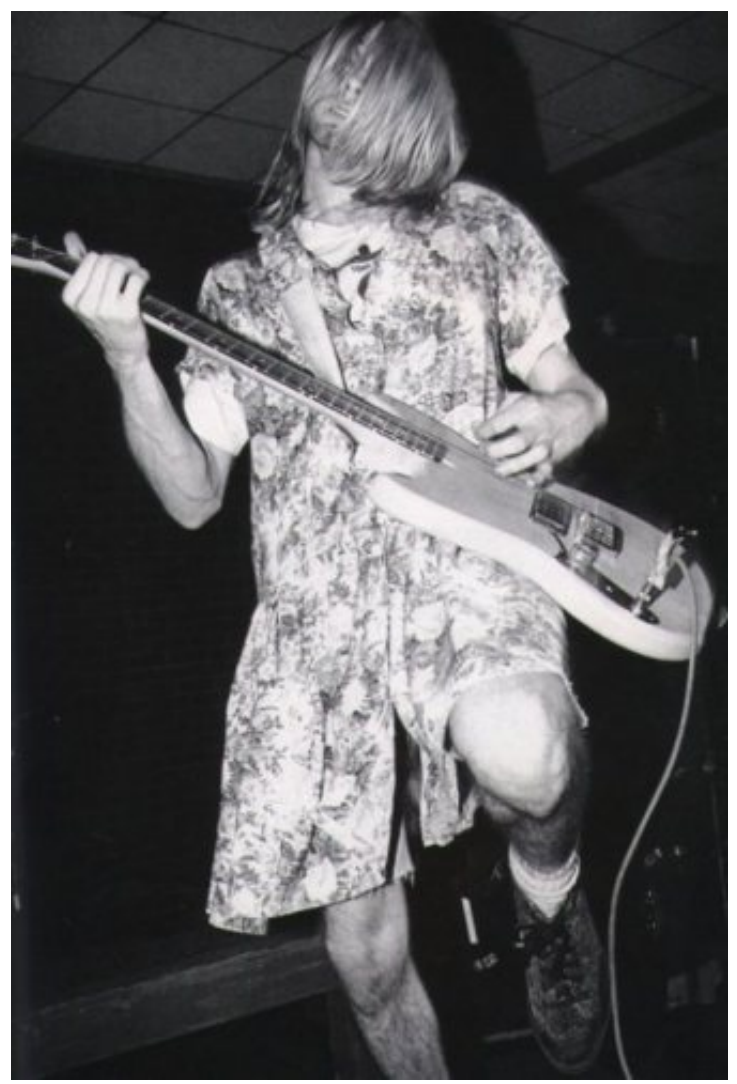

The successful adaptation of grunge to high fashion rankled both young thrift-store devotees and established couture designers. Jean-Paul Gaultier's dismissive statement that "grunge is nothing more than the way we dress when we have no money," was pretty much the same argument made by die-hard fans of early 1990s Seattle-area grunge bands. True, Cobain and his original band mates spent their high school days in the rural town of Aberdeen, Washington, where thrift stores and leisure time were plentiful and money was not. ${ }^{4}$ Homeless at times, Cobain slept on friends' couches and even under a bridge. Still, grunge clothing was not just a practical default. Cobain, like Nirvana's future drummer

\footnotetext{
${ }^{4}$ For more on the history and influences surrounding grunge music and style, see Kyle Anderson, Accidental Revolution: The Story of Grunge (New York: St. Martin's Press, 2007). For more on Nirvana's rise to fame, see Michael Azerrad, Come As You Are: The Story of Nirvana (New York: Broadway Books, 2001). Numerous biography exist on Kurt Cobain, including Charles R. Cross, Heavier Than Heaven: A Biography of Kurt Cobain (New York: Hyperion, 2001).
} 
Dave Grohl across the continent in Virginia, knew he wanted to be a rock star before puberty, and he crafted his personal style accordingly, even in destitution. Secondhand, as (mostly) inherently cheap but not inherently unfashionable, enabled this pursuit. The unmasked cheapness of grunge echoed a century and a half of elective poverty's alliance with artistic pursuits.

Long before Perry Ellis designer Marc Jacobs was hailed as the "guru of grunge" for marketing hundred-dollar cashmere thermals, gender-bending thrift-store styles were firmly associated with rock musicians, traceable at least through 1970s glam rock. Though the cynical sartorial tone and overall grittiness of grunge musicians was recognizably different from the poppier trends of the 1980s, they owed their origins to New Wave bands of the late 1970s and 1980s, whose architects were in turn influenced by glam rockers. Members of Nirvana grew up admiring not only Black Sabbath and K.I.S.S. but also second-generation glitter boys (and girls) like those in R.E.M and especially, the B-52's.

Cobain first caught sight of the B-52's on Saturday Night Live when he was twelve. The band's televised performance reportedly kick-started Cobain's love of New Wave music and style, and inspired him to paint black and white squares on his sneakers in imitation of vocalist Fred Schneider's checkerboard Vans. ${ }^{5}$ In Virginia, an adolescent Grohl was similarly enamored - unlike Cobain, though, Grohl had the means to buy a pair of checkerboard Vans. The totality of the band's image still impressed Grohl years later: "The women looked like they were from outer space, and everything was linked

\footnotetext{
${ }^{5}$ Ian Halperin and Max Wallace, Who Killed Kurt Cobain?: The Mysterious Death of an Icon (New York: Citadel Books, 1999), p. 16.
} 
in - the [record] sleeves, the sound, the clothes, the iconography, the logo, everything." 6

As Vogue described it in 1992, grunge was a "sartorial representation of nihilism that had been evolving around members of the college rock and hardcore." ${ }^{, 7}$ This “nihilism” was rooted in playful, kitschy New Wave nostalgia, elements of which remained apparent in grunge style, especially through male cross-dressing. Much as Jack Smith forged the way for the Cockettes, Andy Warhol, and the New York Dolls, the dress-donning, retro-style elements of grunge hailed from exposure to 1980s "alternative" pop bands, specifically a handful of late 1970s and early 1980s groups from Athens, Georgia, exemplified by the B-52's, "a tacky little dance band" formed in $1976 .{ }^{8}$

The B-52's pioneered a New Wave image that evoked a Jack Smith-esque trash aesthetic and creative parodying, using mostly secondhand materials gleaned from places like Potter's House, the Athens thrift store run by rehabilitating alcoholics. ${ }^{9}$ Among a small but highly visible crowd of young University of Georgia students and local glaminspired partiers, the lineage from Smith and the Cockettes was clear: "they took Alice Cooper as inspiration and the New York Dolls as fashion advisors. All the boys, straight or gay, had at least one dress in their closets; all the girls had their Charlie Chaplin look."10 They scoured area thrift shops looking for the right costume-party clothes, bought gallons of Aqua-Net, and danced all night.

After their first gig playing a Valentine's Day party in 1977, the newly named B52's - not after the bombers, but for the bouffant hairstyle popular in the era they so

\footnotetext{
${ }^{6}$ Jeff Apter, “The Family Way," The Dave Grohl Story (London, Omnibus Press, 2006).

${ }^{7}$ Marin, "Grunge: A Success Story," p. V1.

${ }^{8}$ For more on the B-52's, along with other Athens' bands such as R.E.M. and Pylon, see Rodger Lyle Brown, Party Out of Bounds: The B-52s, R.E.M., and the Kids Who Rocked Athens, Georgia (Atlanta, GA: Everthemore Books, 2003. Originally Published 1991).

${ }^{9}$ Brown, Party Out of Bounds, p. 16.

${ }^{10}$ Brown, Party Out of Bounds, p 26.
} 
thoroughly referenced, the late 1950s and early 1960s — were a local hit. Their eponymous first album was an immediate success, and included several chart-topping singles. As central to their total image as their synthesizer-based sound was their "thriftstore detritus look." ${ }^{11}$ Rolling Stone's review of the B-52's second album, Wild Planet (1980) called the group "connoisseurs of trash in a world full of it." Critics focused on the band's absurdist versions of 1950s and 1960s style and culture. Their sound used "B movie 'sci-fi' keyboard sounds and surf riffs," and live shows incorporated invented dance fads with evocatively old-school names like Aqua-Velva. ${ }^{12}$ As Grohl would say twenty years later, they had "a real unified feel." 13

The B-52's interest in cheaply made and fleetingly iconic cultural ephemera originating in a time just out of their childhood memories' reach was like Jack Smith's evocation of 1940's B movies. But unlike Smith's Flaming Creatures, the B-52's performances were not interpreted as sinister, shocking, or even particularly arty. They were party rock musicians, and their members dressed like they were going to a spaceage themed soiree. The B-52's specific nostalgia for the late 1950s and early 1960s reflected a fixation on what Elizabeth Guffy called "yesterdays' tomorrows, " including space race fixations and a utopian ideal of suburbia. ${ }^{14}$ And the only thing kitschier than the female band members wearing aprons and high heels while carrying a rolling pin was when the men dressed like cocktail waitresses.

The sartorial kitsch of genderfuck dress was, by the late 1980s, shorthand for musical pop. When another Athens scenester-turned-rocker, R.E.M.'s singer Michael

\footnotetext{
${ }^{11}$ Brown, Party Out of Bounds, p. 36.

${ }^{12}$ Theodore Cateforis, Are We Not New Wave?: Modern Pop at the Turn of the 1980s (Ann Arbor, MI: University of Michigan Press, 2011), 95.

${ }^{13}$ Apter, "The Family Way."

${ }^{14}$ Elizabeth L. Guffey, Retro: The Culture of Revival (London: Reaktion Books, 2006).
} 
Stipe, wore a dress at a 1989 Syracuse, New York performance, the implications of male rock stars in women's clothing on stage had at least fifteen years of examples to follow. According to a writer for the Observer, "the dress has a particular significance: it marks R.E.M.'s passing from their cult rockband status to the blurred, warping world of pop stardom. ${ }^{" 15}$ By the late 1980s, boys in bands in thrift-store dresses signaled high-energy rock, following in the sparkling footsteps of glam.

The way Cobain wore dresses of all kinds, both on and off stage, paired with dirty undershirts and ragged boots, underscored a generational understanding of the out-dated kitschiness of gendered dress. According to Cobain's remarks to the L.A. Times, wearing women's clothes revealed a cynical awareness of culturally ascribed gender ideology, as well as a nonchalance about sexuality. "Wearing a dress shows I can be as feminine as I want," Cobain remarked, adding, "I'm a heterosexual. . . big deal. But if I was a homosexual, it wouldn't matter either."16 "Feminine" here goes unexamined, but with his broad-stroke portrayal, Cobain's was an unconventional interpretation.

More importantly than sexual transgression, or even gender deviance, Cobain's dresses were a knowing wink, demonstrating his savvy about pop music. Paired with white socks, undershirts, and dirty boots, his total style was obviously not just the result of slim-pickings at the Aberdeen Goodwill, but a self-conscious assessment of and elaboration on an established pop uniform. In the 1990s, for both males and females, dressing from thrift shops was a rite of passage and a mode of personal identity transformation intimately tied to musical pursuits. The cultivated irony with which it was

\footnotetext{
${ }^{15}$ Jon Savage, “R.E.M.: Post-Yuppie Pop,” Observer 21 May 1989, repr. In Jon Savage, Time Travel: Pop, Media, and Sexuality, 1976-1996 (London: Chatto \& Windus, 1996), pp. 250- 251. ${ }^{16}$ Qtd in Amy Wallace and Handsome Dick Manitoba, The Official Punk Rock Book of Lists (New York: Backbeat Books, 2007), p. 125.
} 
worn did not dampen the reported exhilaration experienced by, for example, Allison Wolfe of Bratmobile, an all-female, feminist band that, along with Bikini-Kill, challenged the male-dominated grunge era with their "Riot Grrrl" style and sound. ${ }^{17}$ In an interview, Wolfe discusses what she did immediately after "something clicked" during a violent altercation with her high school jock boyfriend, inspiring her to change her lifestyle. "I chopped off one side of my hair, and started wearing crosses, eyeliner, thrift store clothes. . I got really more into music."18

Incorporating an alternative style and unconventional musical pursuits required alternative forms of consumption. When the Riot Grrrl movement quickly stalled and sputtered out, Wolfe attributed its demise to the co-optation of their style by mainstream consumer outlets like Urban Outfitters - which, though it had existed since the 1970s, gained widespread popularity in 1990s. "You know, you'd go to Urban Outfitters and the fake riot grrrl bands playing over the loudspeakers, all these clothes that were just like what we would wear. . we ended up just kind of abandoning it, because it became so trendy, and it wasn't our fault," Wolfe claimed. ${ }^{19}$

In 1993, Urban Outfitters was the "clearinghouse of the young and now." The stores' stock looked "as if it came from a design house run by the Salvation Army." ${ }^{20}$ In fact, some of it did. Outfitters took a page from Lord \& Taylor's 1957 playbook, and sold clothing that was actually pre-owned, calling it, of course, vintage: "For those who wouldn't deign to go to an actual thrift store, Outfitters has its own line of vintage

\footnotetext{
${ }^{17}$ For more on Riot Grrrl, see Sara Marcus, Girls to the Front: The True Story of the Riot Grrl Revolution (New York: HarperCollins Publishers, 2010);

${ }^{18}$ Greg Prato, Grunge is Dead: The Oral History of Seattle Rock Music (Toronto: ECW Press, 2009), p. 304.

${ }^{19}$ Prato, Grunge is Dead, p. 304.

${ }^{20}$ Peter Gilstrap, "Not-So-Radical Chic,” The Washington Post 12 Sep 1993, pp. 35.
} 
apparel: Urban Renewal." ${ }^{21}$ Major city branches of the store also displayed found objects like art, replicating what was cool and hip about secondhand outlets and minimizing the discomfort or inconvenience of wading through undesirable wares and bearing with the glaring fluorescence and cheap, cracked tiling of thrift stores.

Mostly, Urban Outfitters sold newly produced retro-style clothes, introducing kids only barely too young to remember them to brands like Hang Ten and Stussy, labels whose brief moment of iconicism had only just ended half a generation ago. Not only had the process of appropriation sped up, as Jacobs' haute couture grunge line shows, but the cycle of re-appropriation accelerated as well. Whereas 1960s hippies sought clothing from a full fifty years ago, 1990s hipsters relied on references not even a decade old. Arguably, the fad for secondhand had created a scarcity issue, causing shoppers to resort to more and more recent reflections of style history. Or, the search for an unused allusion brought trendsetters closer and closer to their own time. Cobain and others helped by making the clearly unfashionable fashionable. The pastel striped surfer shirt Cobain wore on MTV's Unplugged in 1992 was almost absurdist in any claims to coolness — not old enough to be retro, but definitely not au courant. Unhip was hip.

Whether regurgitating styles from last year or last century, Urban Outfitters replicated secondhand clothes that, for the diligent shopper, would be creative, surrealist "sudden parallels" when found amidst the racks of nurse's scrubs and Dress Barn shifts at the local thrift store. But stores like Urban Outfitter removed the necessity for hunting, mostly by recreating looks in combinations just hip enough to excite youth into spending their still-increasing disposable incomes but not daring enough to alienate the unadventurous among them — a sales associate admitted that the store tended to be "on

${ }^{21}$ Gilstrap, "Not-So-Radical Chic," p. 35. 
the safer side of cutting edge." ${ }^{22}$ Even though scholars describe places like Urban Outfitters as examples of Jean Baudrillard's hyperreal—-a place that is a map without a history"-Urban Outfitters comes from and relies upon the long history of secondhand. ${ }^{23}$

Dick Hayne, the owner and CEO of Urban Outfitters, which included the brand Free People and, later, the higher-end chain store Anthropologie, began his business the same year Abbie Hoffman wrote "Steal This Book"-1970. Hayne's first store was a head shop in Philadelphia, the Free Peoples Store. Despite the name and at least hinted-at appropriation of the Digger's modus operandum, Hayne's pursuits were firmly capitalist. The original 400 square-feet worth of "used clothes, T-shirts, housewares, dope paraphernalia, and ethnic jewelry" were sold from the start, and Hayne pursued expansion and adapted to his target audience with great marketing savvy. Making good use of his degree in anthropology, he crafted a commercial environment just exotic enough to appeal to aspiring young hipsters. By 1976, the original venue name, Free Peoples Store, had worn out its hippie appeal, and the chain was rechristened Urban Outfitters. ${ }^{24}$

In the final decades of the twentieth century, secondhand style still relied on surrealist opinions and practices. It built on innovations from underground art, glam rock, and similar types of performances. Such displays used clothing to enhance audience perceptions of music, theater, and film. Individuals adapted the styles to project a culturally valuable eccentricity. The "retro-rock" stylings of the B-52's and the tongue-

\footnotetext{
${ }^{22}$ Gilstrap, "Not-So-Radical Chic," p. 35.

${ }^{23}$ Jean Baudrillard outlines his notions of the hyperreal in Simulacra and Simulation (trans. by Sheila Faria Glaser; Ann Arbor, MI: University of Michigan Press, 1981). Raymond F. Betts correlates the hyperreal with Urban Outfitters in Betts with Liz Bly, A History of Popular Culture: More of Everything, Faster and Brighter (New York: Routledge, 2013), p. 148.

${ }^{24}$ Gilstrap, "Not-So-Radical Chic," p. 35.
} 
in-cheek gritty prettiness of Kurt Cobain were just a few examples of the long-standing use of bodies and appearances as necessary parts of popular musical performances, heightened by the spread of music videos.

The examples given, the paths traced here, were not the only ones that charted the trajectory of secondhand commerce in the twentieth century. And they are certainly not terminal. After Kurt Cobain — a habitual heroin user — took his own life in 1994, styles straight-facedly called shabby chic, heroin chic, or poor chic enjoyed greater cultural currency than ever before. ${ }^{25}$ These productions of style represented a culturally dangerous and socially detrimental kind of intentionally "bad taste." "Fashionizing" poverty—as exampled by House of Dior's 2000 line of "hobo chic"—obscures the real costs of poverty and homelessness for those entrenched in it. ${ }^{27} \mathrm{~A}$ designer who does "a poor-girl look that only a rich one could afford" risks trivializing the human suffering of those whose rags are not affect, whose denim is "naturally" distressed. ${ }^{28}$

Of course, by the time these trends made it to haute couture, the materials used were not secondhand. They are inspired by and transmitted through the popularity of secondhand consumption, but cannot retain any of the suggestion of secondhand's sometimes-professed economic radicality. But the accumulation, sourcing, distribution, repackaging, and profit-making of secondhand clothing itself also became enormously

\footnotetext{
${ }^{25}$ Sociologist Karen Bettez Halnon gives pages of examples, such as designer' "street-person chic" attire, emaciation, Kid Rock, Prada bowling shoes, "shantytown chic" funk balls - to name only a small handful of cultural imitations of poverty from the late 1990s. See Halnon, "Poor Chic: The Rational Consumption of Poverty," Current Sociology 50.4 (July 2002): 501-516. ${ }^{26}$ Kitsch is often described as exhibiting and glamourizing "bad taste." For example, see Gillo Dorfles, Kitsch: The World of Bad Taste (Ann Arbor, MI: University of Michigan Press, 1969). ${ }^{27}$ See for example Maureen Dowd, "Homeless Chic," Denver Post 24 January 2000, p. B6. ${ }^{28}$ The quote refers to 1993 couture by Rei Kawakubo of the Japanese design label Comme des Garçons. See Trish Donnally, "Young Designer's Street-Person Chic/More Rags and Tatters from Paris, San Francisco Chronicle, 16 March 1993, p. B3.
} 
complex and concatenated, as more and cheaper firsthand clothing increased the volume — and decreased the quality—of used offerings. ${ }^{29}$ EBay and other Internet auctioning sites expanded the scope of secondhand exchange as all commerce globalized. Urban Outfitters original ostensible connection to potentially radical uses of secondhand are more than belied by their later products" "Made in" labels, which indicated countries whose factory conditions and worker wages were far below American standards. ${ }^{30}$

Moreover, international goods recycling companies with modest mid-century beginnings were by the 1990s, hugely profitable, and not without their share of scandals. Thrift shops like those of the Salvation Army and Goodwill Industries relied on such companies to manage the increasing amount of unsalable clothing they received. The Domsey Trading Corporation, a secondhand clothing export company started by GermanJewish immigrants in New York City just after World War II, grossed an estimated $\$ 40$ million in 1996. That profit was accrued while the wealthy corporation still faced intensely negative publicity in the wake of several lawsuits for labor violations. The first lawsuit, filed in 1990, International Ladies' Garment Workers' Union vs. Domsey Trading Corporation, stemmed from the illegal firing of unionizing workers-mostly Haitian immigrants—-and the harassment of striking workers. ${ }^{31}$

\footnotetext{
${ }^{29}$ For more on the global growth of cheap clothing consumption, see Elizabeth L. Cline, Overdressed: The Shockingly High Cost of Cheap Fashion (New York: Penguin Group, 2012). ${ }^{30}$ Yet, at Kaya Oakes points out, Urban Outfitters sell themselves as hiply "Indie." See Oakes, Slanted and Enchanted: The Evolution of Indie Culture (New York: Henry Holt and Company, 2009), pp. 197-201.

${ }^{31}$ Karen Tranberg Hansen, Salaula: The World of Secondhand Clothing and Zambia (Chicago: University of Chicago Press, 2000), p. 113. For more on Domsey's "blatent disregard for the law," see Richard W. Hurd and Joseph B. Ueblein, "Patterned Responses to Organizing: Case Studies of the Union-Busting Convention," pp. 61-74 in Sheldon Freeman et al., eds., Restoring the Promise of American Labor Law (Ithaca, NY: Cornell University Press, 1994), p. 68.
} 
The developments of a global secondhand market and the adaptations of poor dress by high fashion developed alongside the imaginative use of secondhand goods to break down restrictive formulas of gender, sexuality, and class, to create aesthetically and politically groundbreaking art, and to provide incomes for small entrepreneurs. From before the Salvation Army sold dancing girls used bronze heels and made children's coats from discarded automobile upholstery, secondhand commerce was an incorporated part of the broader cultural economy, reacting to, encouraging, establishing, and resisting major consumer trends. The fashion of secondhand has retained an air of rebelliousness into the twenty-first century, rebelliousness that still comes from bucking middle-class standards of cleanliness and order. The cultural memory of when used clothing carried deadly communicable diseases lingers just enough to lend a sexily dangerous and adventurous air to obviously old clothes.

However, since the growth of Urban Outfitters and other ultra-inexpensive chain like $\mathrm{H} \& \mathrm{M}$ and Forever 21, secondhand style no longer represented an affordable alternative suggesting cross-class alliance. ${ }^{32}$ Thanks to globalized labor, American shoppers do not need an affordable alternative. Today, Hollywood celebrities boast about thousand-dollar vintage Chanel dresses, and 1950s Lucite bracelets go for as much as a good used Honda. Well-made older clothing, though no longer cheap, is the choice of advocates for under-consumption. Carefully cultivated secondhand styles still represent an alternative consumerism, but to what they are an alternative has changed.

\footnotetext{
${ }^{32}$ When Elizabeth Cline examined the labels at one New York City Goodwill, she found that one in five were from Old Navy, H \& M, Forever 21, or Target. See Cline, The Afterlife of Cheap Clothing, 131.
} 


\section{Bibliography}

\section{Archives}

Bill Bowers papers (\#2001-16), San Francisco GLBT Historical Society

The Diggers Papers, Diggers archives at www.diggers.org Last accessed June 2013.

Ed Collins personal papers, National Flea Market Association [NFMA]

Fashion Institute of Technology, Special Collections and FIT Archives

Jose Sarria Papers (photo box 6, \#1996-01), San Francisco GLBT Historical Society

Joyce F. Menschel Photography Library at the Metropolitan Museum of Art

Kreemah Ritz Papers and tapes (\#1996-37), San Francisco GLBT Historical Society

Kreemah Ritz Paper from the San Francisco Public Library Archives (GLC uncat)

New York City Municipal Archives [NYCMA]

The Salvation Army National Archives of [TSANA]

Newspapers and Magazines

American Home
Better Homes and Gardens
Business Week
Christian Science Monitor
Chicago Daily Tribune
Chicago Tribune
Chicago Sun-Times
Denver Post
Door
Earth
Ft. Worth Daily Gazette
Gay Sunshine
Gentry
Good Housekeeping
Good Times
Guardian Weekend
Italian L-Uomo Vogue
Kiplinger's Personal Finance
Ladies' Homes Journal
Los Angeles Times
Liberation
Life
Look
Masses

Medical News

Newsweek

New York

Observer

Octopus

Orlando Sentinal

Outlook

Rags

Rolling Stone

San Francisco Chronicle

Saturday Evening Post

The Berkeley Barb

The Great Speckled Bird

The Lyre of Alpha Chi Omega

The New York Times

The New Yorker

The Washington Post

Time

Vector

Village Voice

Vogue

Vogue, U.K.

Wall Street Journal 


\section{Interviews and Email Correspondences}

Barron, Gail. Interview with the author. Digital recording. October 30, 2006.

Barron, Gail. Email in possession of the author, July 27, 2005.

Collins, Ed. Interview with the author. Digital recording. November 4, 2006.

Hauser, Fayette. Interview with the author. Digital recording. November 22, 2010.

Jane Ormsby-Gore, conducted by the Victoria \& Albert Museum. http://www.vam.ac.uk/content/articles/i/jane-ormsby-gore/ Accessed June 20, 2013.

Missabu, Rumi. Interview with the author. Digital recording. September, 2010.

Stokes, Jerry. Interview with the author. Digital recording. November 25, 2006

Terry Goodson. Interview with the author. Digital recording. September 9, 2005

Tosches, Nick. Interview with Patti Smith. The Nick Tosches Reader. New York: Da Capo Press Books, 2000.

\section{Films/Documentaries/Television}

Allen, Woody. Annie Hall Beverly Hills, CA: United Artist1977. DVD.

Bates, Kathy. Tupperware! directed by Laurie Kahn-Leavitt, Crossroad Films, 2004. DVD>

Crowe, Cameron. Singles. Burbank, CA: Warner Bros., 1992. DVD.

Eshel, Shuli. Maxwell Street: A Living Memory. Kartemquin Films, 2008. DVD.

"Ladies’ Day," The Flintstones. Directed by Willam Hanna and Joseph Barbera. Los Angeles, CA: Hanna Barbera. First broadcast Nov. 23, 1962.

Leave It to Beaver, Episode 37. Directed by Norman Tokar and written by Joe Connelly and Bob Mosher. First broadcast 25 June 1958 by ABC.

McCarthy-Miller, Beth. director, Nirvana: MTV Unplugged. New York: Geffen Records, 2007. DVD.

Pickup, Gregory. Pickup's Tricks, Unreleased film in author's possession, 1973. DVD

Ranstrom, Phil. "Cheat You Fair”: The Story of Maxwell Street. Rantrom, documentary DVD.

Sebak, Rick. “A Flea Market Documentary.” Pittsburgh: WQED Pittsburgh, Public Broadcasting System, 2001. DVD.

Shea, Mike. And This is Free. Shanachie, 2008. DVD.

“Two Ford Freedom,” Ford Television Commercial. Prelinger Archives, 1956. 
http://archive.org/details/TwoFordFreed. Accessed March 2012.

Weber, Bill and David Weissman. The Cockettes, documentary, 2002. DVD.

Published and Unpublished Memoirs/Reminiscences/Autobiographies/Journals

Booth, Evangeline. The Harp and the Sword: Published and Unpublished Writings and Speeches of Evangeline Cory Booth. Salvation Army Literary Dept., USA Eastern Territory, 1992.

-------- and Grace Livingston Hill. The War Romance of the Salvation Army. Philadelphia and London: J. B. Lippincott Company, 1919.

Brinkley, Douglas ed., Windblown World: The Journals of Jack Kerouac, 1947-1954. New York: Viking, 2004.

Cassady, Neal. The First Third. San Francisco: City Lights Books, 1971.

Collins, Jane. "What I Got Out of the War," in Mary Susannah Robbins, ed., Against the Vietnam War: Writings by Activists. Syracuse, New York: Syracuse University Press, 1999.

Coyote, Peter. Sleeping Where I Fall: a Chronicle. Washington D.C.: Counterpoint, 1998.

Edwards, Robert. Bob Edwards' Guide to Greenwich Village and all through Life with Map History Directory Music Verse Pictures Advice \& Formula for Art, Love, Etc. . . New York: The Quill, 1919.

Grogan, Joshua. Ringolevio: A Life Played for Keeps. New York: New York Review of Books, 1972.

Hapgood, Hutchins. A Victorian in the Modern World. Seattle and London: University of Washington Press, 1972.

Helms, Edgar J. Pioneering in Modern City Missions. Boston: Morgan Memorial Printing Dept., 1944.

Hoffman, Abbie. Soon to Be a Major Motion Picture. New York: Perigee Book, 1980.

Johnson, Joyce. Minor Characters: A Beat Memoir. New York: Penguin Press, 1981.

Lake, Bambi and Alvin Orloff. The Unsinkable Bambi Lake: A Fairytale Containing the Dish of Cockettes, Punks, and Angels. San Francisco: Manic D Press, 1996.

Lipton, Lawrence. The Holy Barbarians. New York: Julian Messner, Inc., 1959.

Malcolm X and Alex Haley. The Autobiography of Malcolm X. Ballantine Books, 1999.

Orcutt, William Dana. The Magic of the Book: The Story of Collecting. London: Herbert Jenkins, 1924.

Tent, Pam. Midnight At the Palace: My Life as a Fabulous Cockette. New York City: Alyson 
Books, 2004.

\section{Published Industry Manuals/Guidelines}

Dallas, Helen. How to Win on the Home Front, Public Affairs Pamphlet No. 72. New York: Public Affairs Committee, 1942.

Kimbell, Horace Warren. This Is Goodwill Industries: An Address at New York. New York: The Newcomen Society in North America, 1962

Oaks, L. Clinton. Managing Suburban Branches of Department Stores. Stanford, Calif., 1957.

Subcommittee on Memorial History, Fifty Years of Boston: a memorial volume issued in commemoration of the tercentenary of 1930. Boston: Tercentenary Committee, 1932.

"The Flea Market Industry: Economic and Legislative Impact Data." From the personal papers of Ed Collins: National Flea Market Association, 2006.

The Goodwill Industries: A Manual, A History of the Movement, Departmental Methods of Work, Religious and Cultural Activities, Administration and Organization. Boston: Morgan Memorial Goodwill Press, 1935.

"The Spiritual, Social and Economic Implications of the Goodwill Movement," Purpose and Policies of Goodwill Industries. Milwaukee: The Bureau of Goodwill Industries and the National Association of Goodwill Industries, 1936.

Tupperware: A Household Word in Homes Everywhere! Product catalog. Orlando, Fl.: Tupperware, Home Parties, 1957.

\section{$\underline{\text { Songs }}$}

Clarke, Grant and James F. Hanley. "Second Hand Rose.” New York: Shapiro, Bernstein \& Co., 1921.

MacDonald, Ballard and James F. Hanley. "Rose of Washington Square.” New York: Shapiro, Bernstein \& Co., 1920.

\section{Primary Books and Journal Articles}

Adorno, Theodor and Max Horkheimer, "The Culture Industry: Enlightenment as Mass Deception," in Dialectics of Enlightenment. New York: Verso, 1997. Originally published in 1944.

------. "Kitsch," in Adorno, Essays on Music. Berkeley and Los Angeles: Univeristy of California Press, 2002. Originally published in 1934. pp. 501-505.

Alexander, J. P. "Sales of Materials.” Electric Railway Journal 23 (January 1915): 192-93.

Antin, Mary. At School in the Promised Land. New York: Houghton-Mifflin Company, 1912. 
Breton, André. Nadja. Translated by Richard Howard. New York: Grove Press, Inc., 1960. Originally published in 1928.

Carlin, Eva V. “A Salvage Bureau.” Overland Monthly (September 1900): 246-57.

Carnegie, Andrew. "Wealth." North American Review (June 1889): 653-54.

-------. “The Best Fields of Philanthropy.” North American Review (December 1889): 682-98.

------. "The Gospel of Wealth” and Other Timely Essays. New York: New York Century Co., 1901.

Carver, T. N. "Thrift and the Standard of Living," Journal of Political Economy 28. November 1920.

Champfleury, Les Excentriques. Paris: Michel Levy, 1855.

Coon, Horace. Hobbies for Pleasure and Profit: New Worlds of Fun and Relaxation for Everyone New York: New American Library, 1955.

Didion, Joan. "Slouching Towards Bethlehem, in Slouching Towards Bethlehem. New York: Dell, 1968.

Dyer, Walter. The Lure of the Antique. New York: Century, 1910.

Engels, Frederick. "Outlines of a Critique of Political Economy, in Karl Marx, Frederick Engels: Marx and Engels: 1843-1844, ed. Jack Cohen et al. New York: International Publishers, 1843-1844.

Flugel, J. S. The Psychology of Clothes. New York: International Universities Press, Inc., 1971. Originally published 1930.

Ginsberg, Allan, “A Definition of the Beat Generation," in Deliberate Prose: Selected Essays, 1952-1995, Bill Morgan, ed. New York: HarperCollins, 2000.

Henry, Jules. Culture Against Man. New York: Vintage Press, 1963.

Lynch, Gerald. Roughnecks, Drillers, and Tool Pushers. Austin: University of Texas Press, 1987.

Gans, Herbert. The Levittowners: Ways of Life and Politics in a New Suburban Community. New York: Pantheon Books, 1967.

Grigg, Harry H. and George E. Haynes, text by Albert E. Webster Junk Dealing and Juvenile Delinquency. Chicago: Juvenile Protective Association, 1919[?].

Hanisch, Carol. "The Personal is Political," in Shulamith Firestone and Anne Koedt, eds., Notes from the Second Year: Women's Liberation. New York: Radical Feminist, 1970.

Originally published in 1969. 
Hawes, Harriet and Eleanor Edelman. McCall's Complete Book of Bazaars. New York: Simon and Schuster,1955.

Hoffman, Abbie, Izak Haber, and Bert Cohen. Steal This Book. Cambridge, Mass.: De Capo Press, 2002. Originally published in 1971.

Holmes, John Clellen. "This is the Beat Generation.” In Holly George-Warren, The Rolling Stone Book of the Beats: The Beat Generation and American Culture. New York: Hyperion, 1999. Originally published in The New York Times Magazine, November 16, 1952.

Huntington, Emily H. and Mary Gorringe Luck. Living on a Moderate Income: The Incomes and Expenditures of Street -Car Men's and Clerk's Families in the San Francisco Bay Region. Berkeley and Los Angeles: University of California Press, 1937.

Kerouac, Jack Visions of Cody. New York: McGraw-Hill Book Company, 1973.

-------. “The Beginning of Bop.” In Escapade III, April 1959.

------. On the Road. New York: Penguin Books, 1991. Originally published 1957.

------. Dharma Bums. New York: Penguin Books, 1976. Originally published 1958.

------. Desolation Angels. New York: Riverhead Books, 1995. Originally published 1965.

Lummis, Dayton. Clippings from the Vine: Selections from the Public Works of Dayton Lummis. Bloomington, Indiana, 2009.

Mailer, Norman. Armies of the Night: History as a Novel, The Novel as History. New York City: Penguin Books, 1968.

Mandel, George. Flee the Angry Strangers. New York: Thunder's Mouth Press, 1952.

McClure, Michael. "Painting Beats by Numbers," in The Rolling Stone Book of the Beats. New York: A Rolling Stone Press Book, 1999.

Mead, Emily Fogg. "The Place of Advertising in Modern Business," Journal of Political Economy 9.2 (March 1901).

Mills, C. Wright. "Letter to the New Left," in Alexander Bloom and Wini Breines, eds., "Takin' It to the Streets": A Sixties Reader. New York: Oxford University Press, 1995.

Milinaire, Caterine and Carol Troy. Cheap Chic. New York City: Harmony Books, 1975.

Morrow, Bradford ed., World Outside the Window: The Collected Essays of Kenneth Rexroth (New York: New Directions Books, 1987, originally published 1961

Rigney, Francis J. and L. Douglas Smith. The Real Bohemia. New York: Basic Books, 1961.

Rockefeller, John D. Random Reminiscences of Men and Events. New York: Doubleday, Page and Company, 1909. 
Samuels, Steven ed. Ridiculous Theatre: Scourge of Human Folly, The Essays and Opinions of Charles Ludlam. New York: Theatre Communications Group, Inc, 1992.

Shulman, Alix Kates. Burning Questions. New York City: Alfred A. Knopf, 1978.

Smith, Adam. An Inquiry into the Nature and Causes of the Wealth of Nations. Edwin Cannan, ed. Chicago: University of Chicago Press, 1976. Originally published in 1776.

Smith, Jack. "The Perfect Filmic Appositeness of Maria Montez." in Film Culture, 27 (Winter 1962-63): 28.

Smith, Patti. “dream of rimbaud.” In Early Work, 1970-1979. New York: W. W. Norton \& Company, 1994.

Smith, Patti. Just Kids. New York: HarperCollins Publishers, 2010).

Snyder, Gary. "Bubbs Creek Haircut.” In Mountains and Rivers Without End. Berkeley: Counterpoint, 2008.

Sontag, Susan. “Jack Smith's Flaming Creatures.” In Against Interpretation and other essays. New York: Farrar, Strauss \& Giroux, 1964.

Sontag, Susan. The Volcano Lover: A Romance. New York: Doubleday, 1992.

Sontag, Susan, "Notes on 'Camp,"” in Sontag, Against Interpretation and Other Essays. New York: Farrar, Straus, \& Giroux, 1966, pp. 275-292. Originally published in 1964.

Stedman, Gordon H. “The Rise of Shopping Centers," Journal of Retailing (Spring 1955): 11-26.

Students for a Democratic Society, The Port Huron Statement, original draft, distributed by Alan Haber at the SDS Northeast Regional Conference, April 23, 2006. http://www.sds1960s.org/PortHuronStatement-draft.htm, last accessed May 6, 2013.

Students for a Democratic Society. The Port Huron Statement. Chicago: C.H. Kerr Publishing Company, 1990.

Veblen, Thorstein. The Theory of the Leisure Class: An Economic Study of Institutions. New York and London: The Macmillan Company, 1921. Originally published 1899.

Waters, John. Shock Value. New York City: Thunder Mouth Press, 1995.

Welch, Lew. "In Answer to a Question from P.W." In Lew Welch, Ring of Bone: Collected Poems. San Francisco: City Lights Bookstore, 2013.

Whyte, Jr., William H. "Budgetism: Opiate of the Middle Class,” Fortune (May 1956): 133-137, 164-167.

--------. The Organization Man. New York: Simon and Schuster, Inc, 1956.

-------. "How the New Suburbia Socializes." In The Essential William H. Whyte. New York: Fordham University Press, 2000. 
Wolfe, Tom. The Electric Kool-Aid Acid Test. New York City: Farrar, Straus and Giroux, 1967.

Yezierska, Anzia. Salome of the Tenements. Chicago: University of Illinois Press, 1923.

-------. "Wings." repr. in How I Found America: Collected Stories of Anzia Yezierska. New York: Persea Books, 1991. Originally published in 1920.

Young, Jean and Jim Young. The Garage Sale Manual: Alternate Economics for the People. Westport, CT: Praeger, 1973.

\section{$\underline{\text { Secondary Source Materials }}$}

Abrams, Les. "Urban Marketplaces and Mobile Vendors: The Flea Market in the Metropolitan Economy. A Case Study of Two Flea Markets-Aqueduct and Roosevelt Raceway Flea Markets". Ph.D. diss., City University of New York, 2007.

Amburn, Ellis. Subterranean Kerouac: The Hidden Life of Jack Kerouac. New York: St. Martin's Press, 1998.

------. Pearl: The Obsessions and Passions of Janis Joplin. New York: Warner Books, 1992.

Anderson, Kyle Accidental Revolution: The Story of Grunge. New York: St. Martin's Press, 2007.

Appaduari, Arjun ed., The Social Life of Things: Commodities in Cultural Perspective. New York: Cambridge University Press, 1986.

Apter, Jeff. The Dave Grohl Story. London, Omnibus Press, 2006.

Aron, Cindy. Working At Play: A History of Vacations in the United States. Oxford and New York: Oxford University Press, 1999

Arthur, Linda B. Religion, Dress and the Body. Oxford, New York: Berg, 1999.

Arrington, Leonard J. and Davis Bitton, The Mormon Experience: A History of the Latter-day Saints. New York: Alfred A. Knopf, 1979.

Azerrad, Michael. Come As You Are: The Story of Nirvana. New York: Broadway Books, 2001.

Bailey, Beth L. From Front Porch to Back Seat: Courtship in Twentieth Century. Baltimore, MD: The Johns Hopkins University Press, 1998.

Baudrillard, Jean. Simulacra and Simulation. Translated by Sheila Faria Glaser. Ann Arbor, MI: University of Michigan Press, 1981.

Bayer, Ronald. Homosexuality and American Psychiatry: The Politics of Diagnosis. Princeton: Princeton University Press, 1987.

Belk, Russell W., John F. Sherry, Jr., and Melanie Wallendorf. "A Naturalistic Inquiry into 
Buyer and Seller Behavior at a Swap Meet," The Journal of Consumer Research 14.4 (1988): 13-30.

Bell, Daniel. The Cultural Contradictions of Capitalism. New York: Basic Books, Inc, 1976.

Berkow, Ira. Survival in a Bazaar. New York: Doubleday \& Company, Inc. 1977.

Bernard, Kenneth. "Confronting the Ridiculous/A Theatrical Review with John Vaccaro." Confrontations (Spring/Summer 1976).

Betts, Raymond F. and Liz Bly. A History of Popular Culture: More of Everything, Faster and Brighter. New York: Routledge, 2013.

Bird-David, Nurit and Asaf Darr. "Commodity, Gift, and Mass-Gift: on gift-commodity hybrids in advanced mass consumption cultures," Economy and Society (38:2, 2009): 304-325.

Blackman, Cally. "Clothing the Cosmic Counterculture: Fashion and Psychedelia." In Cristoph Grunenberg and Jonathan Harris, eds. Summer of Love: Psychedelic Art, Social Crisis and Counterculture in the 1960s. Liverpool: Liverpool University Press, 2005.

Blake, Angela. How New York Became American, 1890-1924. Baltimore, MD: The Johns Hopkins University Press, 2006.

Blanchard, Mary Warner. Oscar Wilde's America: Counterculture in the Gilded Age. New Haven and London: Yale University Press, 1998.

Blankenhorn, David, Barbara Dafoe Whitehead, and Sorcha Brophy-Warren, eds. Franklin's Thrift: The Lost History of an American Virtue. West Conshohocken, PA: Templeton Press, 2009.

Blount, Jackie M. Fit to Teach: Same-Sex Desire, Gender, and School Work in the Twentieth Century. Albany: State University of New York Press, 2005.

Bluestone, Daniel. “The Pushcart Evil.” In David Ward and Olivier Zunz, eds. Landscapes of Modernity: New York, 1900-1940. Baltimore, MD: Johns Hopkins University Press, 1992.

Bold, Christine. Selling the Wild West: Popular Western Fiction, 1860 to 1960. Bloomington and Indianapolis: Indiana University Press, 1987.

Bosworth, Patricia. Jane Fonda: The Private Life of a Public Woman. New York City: Houghton Mifflin, 2011.

Bottoms, Stephen J. Playing Underground: A Critical History of the 1960s Off-Off-Broadway Movement. Ann Arbor, Michigan: University of Michigan Press, 2006.

Bouchier, David. The Cats and the Water Bottles: and Other Mysteries of French Village Life. Mid Atlantic Production, 2002.

Bourdieu, Pierre Distinction: A Social Critique of the Judgment of Taste. Oxon: Routledge, 1984. 
Boyer, Christine M. "Critics for sale: Merchandising History at South Street Seaport." In Michael Sorkin. Variations on a Theme Park: The New American City and the End of Public Space. New York: Hill and Wang, 1992.

Brandon, Ruth. Surreal Lives: The Surrealists, 1917-1945. New York: Grove Press, 1999.

Brecht, Stefan. “Jack Smith, 1961-71. The Sheer Beauty of Junk.” In Queer Theatre: The Original Theatre of the City of New York. From the mid-6os to the mid-70s, book 2. New York: Methuen Drama, 1978.

-----. "Family of the f.p. The Theatre of the Ridiculous, 1965-1968." In Queer Theatre, The Original Theatre of the City of New York. From the mid-6os to the mid-70s, book 2. New York: Methuen Drama, 1978.

------. "The Sheer Beauty of Junk." In Queer Theatre, The Original Theatre of the City of New York. From the mid-6os to the mid-70s, book 2. New York: Methuen Drama, 1978.

Bremner, Robert H. Giving: Charity and Philanthropy in Giving. New Brunswick: Transaction Publishers, 1994. American Philanthropy, 2nd ed. Chicago: University of Chicago Press, 1988.

Breen, T.H. The Marketplace of Revolution: How Consumer Politics Shaped American Independence. Oxford: Oxford University Press, 2004.

Breines, Wini. Young, White, and Miserable: Growing Up Female in the Fifties. Chicago: University of Chicago Press, 1992.

Brightman, Carol. Sweet Chaos: The Grateful Dead's American Adventure. New York: Pocket Books, 1998.

Brown, Allison. "Counting Farmers Markets,” Geographical Review 91.4 (Oct., 2001): 655674.

Brown, Clair. American Standards of Living: 1918-1988. Cambridge, Massachusetts: Basil Blackwell Inc., 1994.

Brown, Rodger Lyle. Party Out of Bounds: The B-52s, R.E.M., and the Kids Who Rocked Athens, Georgia. Atlanta, GA: Everthemore Books, 2003.

Buckley, Peter F. "The Old Curiosity Shop and the New Antique Store: A Note on the Vanishing Curio in New York City," Common-place 4.2 (January 2004), accessed May 17, 2013, http://www.common-place.org/vol-04/no-02/buckley/.

Boyd, Nan Alamilla. "Transgender and Gay Male Cultures from the 1890s through the 1960s." In Wide-Open Town: A History of Queer San Francisco to 1965. Berkeley: University of California Press, 2003.

Bushman, Richard L. and Claudia L. Bushman. "The Early History of Cleanliness in America," Journal of American History 74.4 (March 1988): 1213-38. 
Calhoun, Charles W. ed. The Gilded Age: Perspectives on the Origins of Modern America, 2nd ed. Lanham, Md.: Rowman and Littlefield Publishers, Inc., 2007.

Călinescu, Matei. Five Faces of Modernity: Modernism, Avant-Garde, Decadence, Kitsch, Postmodernism. Durham, NC: Duke University Press, 2003.

Carlsson, Chris and Lisa Ruth Elliot, eds. Ten Years That Shook the City: San Francisco, 19681978. San Francisco: City Lights Books, 2011.

Carpenter, Niles. Immigrants and Their Children. Washington, D.C.: Government Printing Office, 1927.

Carr, C. “The World According to Jack Smith.” In C. Carr., ed., On Edge: Performance at the End of the Twentieth Century. Middletown, CT: Wesleyan University Press, 1993.

Carson, Rachel. Silent Spring. New York: Houghton Mifflin, 2002. Originally published in The New Yorker in 1962.

Carter, David. Stonewall: The Riots That Sparked the Day Revolution. New York: St. Martin's Press, 2004.

Castells, Manuel. "Cultural Identity, Sexual Liberation, and Urban Structure: The Gay Community in San Francisco." In The City and the Grassroots: A Cross-Cultural Theory of Urban Social Movements. Berkley and Los Angeles: The University of California Press, 1983.

Cateforis, Theodore. Are We Not New Wave?: Modern Pop at the Turn of the 1980s. Ann Arbor, MI: University of Michigan Press, 2011.

Cavallo, Dominick. A Fiction of the Past: Sixties in American History. New York: Palgrave, 1999.

Chauncey, George. Gay New York: Gender, Urban Culture, and the Making of the Gay Male World, 1890-1940. New York City: Basic Books, 1994.

Christmas, Earl. House of Goodwill: A Story of Morgan Memorial. Boston: Morgan Memorial Press, 1924.

Clark, Jr., Clifford Edward. The American Family Home, 1900-1960. Chapel Hill: University of North Carolina Press, 1986.

Clarke, Alison. Tupperware: The Promise of Plastic in 1950s America. Washington and London, 1999.

Clemente, Deirdre. "Made in Miami: The Development of the Sportswear Industry in South Florida, 1900-1960," Journal of Social History, 41, No. 1 (Fall, 2007): pp. 127-148.

Cline, Elizabeth L. Overdressed: The Shockingly High Cost of Cheap Fashion. New York: Penguin, 2012. 
Cohen, Joanna. "'The Right to Purchase Is as Free as the Right to Sell': Defining Consumers as Citizens in the Auction-house Conflicts of the Early Republic," Journal of the Early Republic 20.1 (Spring 2010): 25-62.

Cohen, Lizabeth. Making a New Deal: Industrial Workers in Chicago, 1919-1939. New York: Cambridge University Press, 1990.

------. A Consumers' Republic: The Politics of Mass Consumption. New York: Knopf, 2003.

-------. Embellishing a Life of Labor: An Interpretation of the Material Culture of American Working-Class Homes, 1885-1915." In American Material Culture: The Shape of Things around Us. Bowling Green, Ohio: Bowling Green State University Popular Press, 1984.

-------. "From Town Center to Shopping Center: The Reconfiguration of Community Marketplaces in Postwar America," The American Historical Review 101.4 (October 1996): 1050-1081, pp. 1075-1077

-------. "A Middle-Class Utopia? The Suburban Home in the 1950s." In Janice Tauer Wass, ed. Making Choices: A New Perspective on the History of Domestic Life. Springfield: Illinois State Museum, 1995.

Cohen, Margaret. Profane Illumination: Walter Benjamin and the Paris of Surrealist Revolution. Berkeley, Los Angeles, London: University of California Press, 1993.

Conley, Catharine. "Surrealism and Outsider Art: From the 'Automatic Message' to André Breton's Collection,” Yale French Studies, 109, Surrealism and Its Others (2006): 129143.

Coutts, Frederich. Bread for My Neighbour: An Appreciation of the Social Influence of William Booth. London: Hodder and Stoughton, 1978.

Cowley, Malcolm Exile's Return: A Literary Odyssey of the 1920s. London: The Bodley Head, revised ed., 1964. Originally published in 1934.

Crewe, Louise and Nicky Gregson. Second-Hand Cultures. Oxford: Oxford International Publishers, Ltd., 2003.

Cross, Charles R. Heavier Than Heaven: A Biography of Kurt Cobain. New York: Hyperion, 2001.

Cunningham, Patricia. Reforming Women's Fashion, 1850-1920: Politics, Health, and Art. Kent \& London: The Kent State University Press, 2003.

D’Emilio, John. "Capitalism and Gay Identity.” In Ann Snitow, Christine Stansell, and Sharon Thompson, eds. Powers of Desire: The Politics of Sexuality. New York: Monthly Review Press, 1983.

Dalzell, Tom. Flappers 2 Rappers: American Youth Slang. Springfield, MA: Mirriam-Webster, Inc., 1996. 
------. Damn the Man!: Slang of the Oppressed in America. New York: Dover Publications, 2010.

Davis, Fred. Fashion, Culture, and Identity. Chicago: University of Chicago, 1992.

Davis, Mary E. Classic Chic: Music, Fashion, and Modernism. Berkeley: University of California Press, 2006.

Decherney, Peter. Hollywood and the Culture Elite: How the Movies Became American. New York: Columbia University Press, 2005.

Deutsch, Tracey. Building a Housewife's Paradise: Gender, Politics, and American Grocery Stores in the Twentieth Century. Chapel Hill: University of North Carolina Press, 2010.

Donahue, Kathleen. Freedom From Want: American Liberalism and the Idea of the Consumer. Baltimore and London: The Johns Hopkins University Press, 2003.

Dorfles, Gillo. Kitsch: The World of Bad Taste. Ann Arbor, MI: University of Michigan Press, 1969.

Eastwood, Carolyn. Near West Side Stories: Struggles for Community in Chicago's Maxwell Street Neighborhood. Chicago: Lake Claremont Press, 2002.

-------. Chicago's Jewish Street Peddlers. Chicago: Chicago Jewish Historical Society, 1991.

Echols, Alice. "Hope and Hype in Sixties Haight-Ashbury." In Shaky Ground: The Sixties and Its Aftershocks. New York: Columbia University Press, 2002.

Echols, Alice. Scars of Sweet Paradise: The Life and Times of Janis Joplin. New York: Macmillan, 2000.

Ekins, Richard and Dave King, Transgender Phenomenon. London: Sage Publications, 2006.

Ensminger, David A. Visual Vitriol: The Street Art and Subculture of the Punk and Hardcore Generation. Jackson, Mississippi: University Press of Mississippi, 2011.

Ernst, Robert. Immigrant Life in New York City, 1825-1863. Syracuse, New York: Syracuse University Press, 1994.

Eskridge, Jr., William. Gaylaw: Challenging the Apartheid of the Closet. Boston: Harvard University Press, 2002.

Eskridge, William N. and John Ferejohn, A Republic of Statutes: The New American Constitution (Yale University Press, 2010

Ewen, Stuart Captains of Consciousness: Advertising and the Social Roots of the Consumer Culture. New York: McGraw-Hill, 1976.

Farber, David. Chicago '68. Chicago: University of Chicago Press, 1988. 
David Farber, "The Counterculture and the Antiwar Movement." In Melvin Small and William D. Hoover, eds. Give Peace a Chance: Exploring the Vietnam Antiwar Movement. Syracuse, New York: Syracuse University Press, 1992.

Egan, James, ed. John Waters: Interviews. Jackson, Mississippi: University of Mississippi Press, 2011.

Fink, James J. The Automobile Age. Cambridge: M.I.T. Press, 1988.

Fisher, James Terrence. The Catholic Counterculture in America, 1933-1962. Chapel Hill: University of North Carolina Press, 1989.

Folpe, Emily Kies. It Happened in Washington Square. Baltimore: The Johns Hopkins University Press, 2002.

Frank, Thomas. The Conquest of Cool: Business Culture, Counterculture, and the Rise of Hip Consumerism. Chicago and London: The University of Chicago Press, 1997.

Franklin, Benjamin. The Way to Wealth. Repr. New York: New York Association for Improving the Condition of the Poor, 1848. Originally published in 1758.

Friedman, Lawrence J. and Mark D. McGarvie. Charity, Philanthropy, and Civility in American History. New York: Cambridge University Press, 2003.

Frith, Simon. Sound Effects: Youth, Leisure, and the Politics of Rock ' $n$ ' Roll. New York: Pantheon, 1981.

Fuller, Robert C. Stairways to Heaven: Drugs in American Religious History. Boulder, Colorado: Westview Press, 2000.

Furlough, Ellen and Carl Strikwerda, "Economics, Consumer Culture, and Gender: An Introduction to the Politics of Consumer Cooperation." In Furlough and Strikwerda, eds. Consumers against Capitalism? Consumer Cooperation in Europe, North America, and Japan, 1840-1990. Lanham, MD: Rowman \& Littlefield Publishers, Inc., 1999, pp. 1-66.

Gamson, Joshua. The Fabulous Sylvester: The Legend, the Music, The Seventies in San Francisco. New York: Henry Holt and Company, 2005.

Garreau, Joel. Edge Cities: Life on the New Frontier. New York: Doubleday, 1991.

Gelber, Steven M. Do-It-Yourself: Constructing, Repairing and Maintaining Domestic Masculinity," American Quarterly 49.1 (March 1997): 66-112.

-------. Hobbies: Leisure and the Culture of Work in America .New York: Columbia University Press, 1999.

Genat, Robert. American Car Dealership. St. Paul: Motorbooks International, 2004.

Giamo, Benedict. Kerouac, the Word and the Way: Prose Artist as Spiritual Quester. Southern Illinois University, 2000. 
Giles, Paul. American Catholic Arts and Fiction: Culture, Ideology, Aesthetics. New York: Cambridge University Press, 1992.

Ginsburg, Madeleine. "Rags to Riches: the Second Hand Clothes Trade, 1700-1978," Costume: The Journal of the Costume Society 14 (London, 1980).

Goat, Leslie G. "Housing the Horseless Carriage: America's Early Private Garages," Perspectives in Vernacular Architecture 3 (1989): 62-72.

Goldman, Herbert G. Fanny Brice: the Original Funny Girl. New York: Oxford University Press, 1992.

Goldsmith, Kenneth, ed., I'll Be Your Mirror: The Selected Andy Warhol Interviews: 1962-1987 New York: Carroll and Graf Publishers, 2004.

Gottfried, Herbert and Jan Jennings, American Vernacular Buildings and Interiors, 1870-1960, New York: W. W. Norton \& Company, 2009.

Greenfield, Briann Out of the Attic: Inventing Antiques in Twentieth-Century New England Amherst and Boston: University of Massachusetts Press, 2009.

Grossman, Barbara W. Funny Woman: the Life and Times of Fanny Brice. Indiana University Press, 1992.

Gordon, Beverly. Bazaars and Fair Ladies: The History of the American Fundraising Fair Knoxville: University of Tennessee Press, 1998.

Gordon, Linda. "Black and White Visions of Welfare: Women's Welfare Activism, 18901945," Journal of American History 78.2 (September 1991): 559-90.

Gorman, Michael R. The Empress is a Man: Stories from the Life of Jose Sarria. New York: The Haworth Press, 1998.

Graham Jr., Otis L. and Elizabeth Koed, “Americanizing the Immigrant, Past and Future: History and Implications of a Social Movement," Public Historian 15 (Fall 1992): 41.

Greenberg, Brian Linda S. Watts, and Richard A. Greenwald, Social History of the United States: The 1900s. Santa Barbara: ABC-CLIO, Inc., 2009.

Grimm Jr., Robert T. "Working with Handicaps: Americans with Disabilities, Goodwill Industries and Employment, 1920s-1970s". Ph.D. diss. Indiana University, 2002.

Gross, Robert A. "Giving in America: From Charity to Philanthropy," In Lawrence J. Friedman and Mark D. McGarvie, eds. Charity, Philanthropy, and Civility. New York: Cambridge University Press, 2003. pp. 32-44.

Grove, Lori and Laura Kamedulski Chicago's Maxwell Street. Chicago: Arcadia Publishing, 2002.

Gurney, Peter J. “"The Sublime of the Bazaar': A Moment in the Making of a Consumer 
Culture in Mid-Nineteenth Century England," Journal of Social History 40.2 (Winter 2006): 386-405.

Gutman, Marta. "Inside the Institution: The Art and Craft of Settlement Work at the Oakland New Century Club, 1895-1923," Perspectives in Vernacular Architecture 8 (2000): 248-79.

Hale, Grace Elizabeth. A Nation of Outsiders: How the White Middle Class Fell in Love with Rebellion in Postwar America. Oxford, New York: Oxford University Press, 2011.

Halnon, Karen Bettez. "Poor Chic: The Rational Consumption of Poverty," Current Sociology 50.4 (July 2002): 501-516.

Halperin, Ian and Max Wallace. Who Killed Kurt Cobain?: The Mysterious Death of an Icon. New York: Citadel Books, 1999.

Hamilton, Neil A. Rebels and Renegades: A Chronology of Social and Political Dissent in the United States. New York City: Routledge, 2002.

Handley, Susannah. Nylon: The Story of a Fashion Revolution. Baltimore, MD: The Johns Hopkins University Press, 1999.

Hansen, Karen Transberg. Salaula: The World of Secondhand Clothing and Zambia. Chicago and London: The University of Chicago Press, 2000.

Harap, Louis. The Image of the Jew in American Literature: From Early Republic to Mass Immigration. New York: Syracuse University Press, 2003.

Harris, Betty. With Courage Adequate .. . With Dignity Intact: The Story of Goodwill Industries of Southern California. Los Angeles: Goodwill Industries of Southern California, 1971.

Hartmann, Susan. “Women's Employment and the Domestic Ideal in the War Years," In Joanne Meyerowitz, Not June Cleaver: Women and Gender in Postwar America, 1945-1960 (Philadelphia: Temple University Press, 1994).

Hayden, Dolores. "Building the American Way: Public Subsidy, Private Space," Unpublished paper delivered at the International Panning History Society conference, Barcelona, Spain, July 17, 2004, repr. in Becky M. Nicolaides and Andrew Weise, eds., The Suburb Reader. New York: Routledge, 2006.

Hays, Samuel P. Conservation and the Gospel of Efficiency: The Progressive Conservation Movement, 1890-1920. Repr. Pittsburgh: University of Pittsburgh Press, 1999. Originally published in 1959.

Hebdige, Dick. Subculture. London and New York: Routledge, 1979.

------. "The Meaning of Mod," in Stuart Hall and Tony Jefferson, eds., Resistance Through Rituals: Youth Subcultures in Post-War Britain. London: Routledge, 1993.

Heitmann, John. The Automobile and American Life. Jefferson, North Carolina: McFarland \& 
Company, Inc, 2009.

Henthorn, Cynthia Lee. From Submarines to Suburbs: Selling a Better America, 1939-1959. Athens, Ohio: Ohio University Press, 2006.

Herrmann, Gretchen M. "Gift or Commodity: What Changes Hands in the U. S. Garage Sale?," American Ethnologist 24. 4 (Nov. 1997): 910-930.

------. "Women's Exchange in the U. S. Garage Sale: Giving Gifts and Creating Community," Gender and Society 10.6 (Dec. 1996): 703-728.

------. "Negotiating Culture: Conflict and Concensus in U. S. Garage-Sale Bargaining," Ethnology 42.3 (Sumer 2003): 237-252.

------. "Haggling Spoken Here: Gender, Class, and Style in US Garage-Sale Bargaining," Journal of Popular Culture 38.1 (August 2004): 55-81.

Hine, Thomas. Populuxe. New York: Alfred A Knopf, 1986.

Hoberman, J. On Jack Smith's Flaming Creatures (and Other Secret-Flix of Cinemaroc). New York City: Granary Books, 2001.

------. “Sight and Sound: Everything Overexposed,” New York 1.9 (January 1992): 4.

Hodgdon, Tim. Manhood in the Age of Aquarius: Masculinity in Two Countercultural Communities, 1965-83. New York: Columbia University Press, 2007.

Horowitz, Daniel. "Consumption and Its Discontents: Simon N. Patten, Thorstein Veblen, and George Gunton," The Journal of American History 67 (1980): 301-17.

-- The Morality of Spending: Attitudes toward the Consumer Society in America, 18751940. Baltimore: Johns Hopkins University Press, 1985.

Hough, Pamela and Stuart Hough. Bit by the Fleas: An Insider's Guide to the Paris Flea Market. Paris: Vilo, 2002.

Hoy, Suellen. Chasing Dirt: The American Pursuit of Cleanliness. New York: Oxford University Press, 1995.

Huddleston, Robert Rollin. "The Relatedness of Goodwill Industries and the Christian Church". Ph.D. diss., Iliff School of Theology, 1959.

Hunt, Bruce. "Webster," in Visiting Small-Town Florida, $3^{\text {rd }}$ ed. Sarasota, Florida: Pineapple Press, Inc., 2011. pp. 131-135

Hurd, Richard W. and Joseph B. Ueblein, "Patterned Responses to Organizing: Case Studies of the Union-Busting Convention," pp. 61-74 in Sheldon Freeman et al., eds., Restoring the Promise of American Labor Law. Ithaca, NY: Cornell University Press, 1994.

Israel, Matthew. Kill For Peace: American Artists Against the Vietnam War. Austin, Texas: The University of Texas Press, 2013. 
Issitt, Micah. Hippies: A Guide to an American Subculture. Santa Barbara, CA: Greenwood Press, 2009.

Jackson, Kenneth T. Crabgrass Frontier: The Suburbanization of the United States. New York: Oxford University Press, 1985.

Jackson Lears, T. J. Fables of Abundance: A Cultural History of Advertising in America. New York: Basic Books, 1994.

------. No Place of Grace: Antimodernism and the Transformation of American Culture, 18801920. Chicago and London: The University of Chicago Press, 1981.

Jacopetti, Alexandra. Native Funk and Flash: An Emerging Folk Art. San Francisco: Scrimshaw Press, 1974.

Jerome, Judith. "Creating the World Waiting to Be Created: Jack Smith and D. W. Winnicott". Ph.D. diss. Department of Performance Studies, New York University, May 2007.

Jezer, Marty. Abbie Hoffman: American Rebel. New Brunswick, New Jersey: Rutgers University Press, 1992.

Johnson, David K. The Lavender Scare: The Cold War Persecution of Gays and Lesbians. Chicago: The University of Chicago Press, 2004.

Johnson, Michael L. The Westers: The West in Contemporary American Culture. Lawrence, KS: University of Kansas Press, 1996.

Johnstone, Nick. Patti Smith: A Biography. London: Omnibus Press, 1997.

Jones, Landon Y. Great Expectations: American and the Baby Boom Generation. New York: Coward, McCann and Geoghegan, 1980.

Jones, Sonya L. Gay and Lesbian Literature Since World War II: History and Memory. Philadelphia: Haworth Press, 1998.

Kaufman, David. Ridiculous! The Theatrical Life and Times of Charles Ludlam. New York: Applause Theatre \& Cinema Books, 2002.

Kennedy, Alicia and Emily Banis Stoehler with Jay Calderin, Fashion Design, Referenced: A Visual Guide to the History, Language \& Practice of Fashion. Rockport Publishers, 2013.

Kessler-Harris, Alice. Out to Work: A History of Wage-earning Women in the United States. New York: Oxford Publishing Press, 1982.

Kirby, Jack Temple. Rural Worlds Lost: The American South, 1920-1960. Louisiana State University Press, 1987.

Kirkland, Kate Sayen. The Hogg Family and Houston. Houston: University of Texas Press, 2009. 
Klaffke, Pamela. Spree: A Cultural History of Shopping. Vancouver: Arsenal Pulp Press, 2003.

Klein, Christina. Cold War Orientalism: Asia in the Middlebrow Imagination, 1945-1961 Berkeley: University of California Press, 2003.

Klepacki, Laura. Avon: Building the World's Premier Company for Women. Hoboken, NJ: John Wiley \& Sons, 2005.

Knuth, Jane. Thrift Store Saints: Meeting Jesus 25 Cents at a Time. Chicago: Loyola Press, 2010.

Koistinen, Paul A. C. Arsenal of World War II: The Political Economy of American Warfare, 1940-1945. Lawrence, KS: University Press of Kansas, 1994.

Kozmetsky, George and Piyu Yue, The Economic Transformation of the United States, 19502000: focusing on the technological revolution, the service sector expansion, and the cultural, ideological, and demographic changes. West Lafayette, IN: Purdue University Press, 2005.

Kostlevy, William. Holy Jumpers: Evangelicals and Radicals in Progressive Era America. Oxford: Oxford University Press, 2010.

Kotynek, Roy and John Cohassey, American Cultural Rebels: Avant-Garde and Bohemian Artists, Writer and Musicians from the 1850s through the 1960s. Jefferson, North Carolina: McFarland \& Company, Inc., 2008.

Krakow, Kari. The Harvey Milk Story. Ambler, Pennsylvania: Two Lives Publishing, 2001.

Krauss, Rosalind. "The Photographic Conditions of Surrealism," October 19 (Winter 1981): 3-34.

Kruse, Kevin Michael. White Flight: Atlanta and the Making of Modern Conservatism. Princeton, New Jersey: Princeton University Press, 2005.

Kuhn, Betsy. Gay Power!: The Stonewall Riots and the Gay Rights Movement, 1969. Minneapolis, MN: Twenty-First Century Books, 2011.

Kulikoff, Allan. "Households and Markets: Toward a New Synthesis of American Agrarian History." The William and Mary Quarterly, 3d Ser., 1.1 (April, 1993): 342-355.

Kusch, Frank. Battleground Chicago: The Police and the 1968 Democratic National Conventio.n Chicago: The University of Chicago Press, 2008.

Kusmer, Kenneth. "The Functions of Organized Charity in the Progressive Era: Chicago as a Case Study,” Journal of American History 60.3 (December 1973): 665.

Laband, David N. and Deborah Hendry Heinbuch, Blue Laws: The History, Economic, and Poltics of Sunday-Closing Laws. Lanham, MD: Lexington Books, 1987.

LaFarge, Albert. U.S. Flea Market Directory, $3^{\text {rd }}$ Edition: A Guide to the Best Flea Markets in All 50 States. New York: St. Martin's Press, 2000. 
Landman, Ruth H. "Washington's Yard Sales: Women's Work, but Not for the Money," City and Society 1.2 (Dec. 1987): 148-161.

Lasch, Christopher. The New Radicalism in America, 1889-1963: The Intellectual as a Social Type. New York: Knopf, 1965.

Lassiter, Matthew D. The Silent Majority: Suburban Politics in the Sunbelt South. Princeton, NJ: Princeton University Press, 2006.

Lastovicka, John and Karen V. Fernandez. "Three Paths to Disposition: The Movement of Meaningful Possessions to Strangers," The Journal of Consumer Research 31.4 (March 2005): 813-823.

Lathers, Marie. Space Oddities: Women and Outer Space in Popular Film and Culture, 19602000. New York City: Continuum International Publishing Group, 2010.

Lawler, William. Beat Culture: Lifestyles, Icons, and Impact. Santa Barbara: ABC-CLIO, 2005.

Leach, William Land of Desire: Merchants, Power, and the Rise of a New American Culture. New York: Pantheon, 1993.

Leffingwell, "The Only Normal Man in Baghdad," in Edward Leffingwell, Jack Smith, and Carole Kismaric, and Marvin Heiferman, eds.,in Flaming Creature: Jack Smith, His Amazing Life and Times. New York: Serpent's Tail, 1997.

Lemire, Beverly. "Consumerism in Preindustial and Early Industrial England: The Trade in Secondhand Clothes.” Journal of Business Studies 27 (1988): 1-24.

Levinson, Mark .The Great A\&P and the Struggle for Small Business in America. New York: Hill and Wang, 2011.

Lewis, David L and Laurence Goldstein, eds, The Automobile and American Culture. The University of Michigan Press, 1980.

Le Zotte, Jennifer. "'Be Odd': The Contradictory Use of Dress in the Gilded Age Salvation Army," Winterthur Portfolio 47, no. 4 (Winter 2012).

Lipsitz, George. “Who'll Stop the Rain?: Youth Culture, Rock 'n' Roll, and Social Crises.” In David Farber, ed. The Sixties: From Memory to History. Chapel Hill: University of North Carolina Press, 1994.

Lobenthal, Joel. Radical Rags: Fashions of Sixties. New York City: Abbeville Press, 1990.

Longstreth, Richard W. City Center to Regional Mall: Architecture, the Automobile, and Retailing in Los Angeles, 1920-1950. Boston: Massachusetts Institute of Technology, 1998.

Lott, Eric. Love and Theft: Blackface Minstrelsy and the American Working Class. New York: Oxford University Press, 1993. 
Lukas, Paul. "The Last Picture Shows," Money 30. 8 (August 2001): 90-96.

Ma, Sheng-Mai. The Deathly Embrace: Orientalism and Asian American Identity. Minneapolis, MH: University of Minnesota Press, 2000.

Mackrell, Alice. Paul Poiret. New York: Holmes and Meier, 1990.

Mandell, Lewis. The Credit Card Industry: A History. Farmington Hills, MI: Twayne Publishers, 1990.

Marchand, Roland Advertising the American Dream: Making Way for Modernity, 1920-1940. Berkeley and Los Angeles: University of California Press, 1985.

Marcus, Sara. Girls to the Front: The True Story of the Riot Grrl Revolution. New York: HarperCollins Publishers, 2010.

Marcuse, Herbert. One-Dimensional Man. Boston: Beacon Press, 1964.

Marranca, Bonnie and Guatam Dasgupta, Theatre of the Ridiculous. New York: Performing Arts Journal Publications, 1979.

Martin, Bradford D. The Theater in the Street: Politics and Public Performance in Sixties America. Amherst and Boston: University of Massachusetts Press, 2004.

Martin, Richard. Charles James. New York City: Assouline Press, 2006.

Mathjis, Ernest and Jamie Sexton. Cult Cinema (John Wiley \& Sons, 2012.

Matthews, Mark. Droppers: America's First Hippie Commune, Drop City. Norman, Oklahoma: University of Oklahoma Press, 2010.

May, Elaine Tyler "The Commodity Gap: Consumerism and the Modern Home," in Consumer Society in American History: A Reader.Ithaca and London: Cornell University Press, 1999.

------. Homeward Bound: American Families in the Cold War Era. New York: Basic Books, 1988.

Maynard, John Arthur. Venice West: The Beat Generation in Southern California. New Brunswick and London: Rutgers University Press, 1991.

Mayo, James. "The American Public Market," Journal of Architectural Education 45 no. 1 (Nov. 1991): 41-57.

McCree, Cree. "Flea Market," Psychology Today 18 (June 1986): 46-52.

McDarrah Fred W. and Gloria S. McDarrah, Beat Generation: Glory Days in Greenwich Village. New York: Schirmer Books, 1996.

McKinley, Edward H. Somebody's Brother: A History of the Salvation Army Men's Social Service Department. Lewiston: The Edwin Mellon Press, 1986. 
------. Marching to Glory: The History of the Salvation Army in the United States of America, 1880-1980. San Francisco: Harper and Row, 1980.

McMillian, John \& Paul Buhle, eds. The New Left Revisited. Philadelphia: Temple University Press, 2003.

McNally, Dennis. Desolate Angel: Jack Kerouac, the Beat Generation, and America. New York: Random House, 1979.

McRobbie, Angela ed., Zoot Suits and Secondhand Dresses: An Anthology of Fashion and Music. Boston: Unwin Hyman, 1988.

Medovoi, Leerom Rebels: Youth and the old War Origins of Identity. Durham, NC: Duke University Press, 2005.

Meikle, Jeffrey L. American Plastic: a Cultural History. New Brunswick: Rutgers University Press, 1995.

Melosi, Martin V. Garbage in the Cities: Refuse, Reform, and the Environment. Rev. ed., Pittsburgh: University of Pittsburgh Press, 2004).

Mendelsohn, Adam. “'It's the Economy, Shmendrick': A New Turn in Jewish Studies?” AJS Perspectives (Fall, 2009): 14-17.

Meyerowitz, Joanne. Women Adrift: Independent Wage Earners in Chicago, 1880-1930. Chicago: University of Chicago Press, 1988.

Miles, Barry. Ginsberg: A Biography. New York: Harper Perennial, 1990.

Miles, Barry. The British Invasion: The Music, The Times, The Era. New York: Sterling Publishing, 2009.

Barry Miles, Hippie. New York: Sterling Publishing Company, 2005.

Miller, Max H. "Patterns of Exchange in the Rural Sector: Flea Markets Along the Highway," Journal of American Culture 2.3 (1988): 55-59.

Miller, Michael B. The Bon Marché: Bourgeois Culture and the Department Store, 1869-1920. Princeton, New Jersey: Princeton University Press, 1981.

Mitchell, Claudia A. and Jacqueline Reid-Walsh, eds. Girl Culture: an Encyclopedia. Westport, CT: Greenwood Press, 2007.

Moffitt, Peggy and William Claxton. The Rudi Gernreich Book. Cologne, Germany: Taschen, 1999.

Montague, Ken. "The Aesthetics of Hygiene: Aesthetic Dress, Modernity, and the Body as Sign," Journal of Design History 7.2 (1994): 91-111.

Monton, Henry L. Departing from Deviance: A History of Homosexual Rights and Emancipatory 
Science. Chicago: The University of Chicago Press, 2002.

Moon, Michael. Small Boy and Others. Durham and London: Duke University Press, 1998.

Moore, Frederick C. The Golden Threads of Destiny. Boston: Morgan Memorial Goodwill Press, 1952.

Moreton, Bethany. To Serve God and Wal-Mart: The Making of Christian Free Enterprise. Boston: Harvard University Press, 2010.

Morrisroe, Patricia. Mapplethorpe: a Biography. New York City: Random Books, 1995.

Murdoch, David Hamilton. The American West: The Invention of a Myth. Reno: University of Nevada Press, 2001.

Murdoch, Norman. Origins of the Salvation Army. Knoxville: University of Tennessee Press, 1996.

Murphy, Patrick D. Understanding Gary Snyder. Columbia, South Carolina: University of South Carolina Press, 1992.

Neth, Mary. Preserving the Family Farm: Women, Community, and the Foundations of Agribusiness in the Midwest, 1900-1940. Baltimore MD: Johns Hopkins University Press, 1998.

Nicholson, Virginia. Among the Bohemians: Experiments in Living, 1900-1939. London, New York: Penguin, 2002.

Olmsted, Jr., Frederick Law. “Introduction.” In John Nolen, ed. City Planning: A Series of Papers Presenting the Essential Elements of a City Plan, NML Series. New York: D. Appleton, 1916.

Paglia, Camille. "What's in a Picture," Civilizations (Dec. 96/Jan 97).

Palmer, Alexandra and Hazel Clark, eds. Old Clothes, New Looks: Second Hand Fashion. New York: Berg, 2005.

Parker, Florence E. "Consumers' Cooperation in the United States," Annals of the American Academy of Political and Social Science, 191 (May 1937).

Peck, Abe. Uncovering the Sixties: The Life and Times of the Underground Press. New York: Pantheon, 1985.

Peiss, Kathy Cheap Amusements: Working Women and Leisure in Turn-of-the-Century New York. Philadelphia: Temple University Press, 1986.

-------- Hope in a Jar: The Making of America's Beauty Culture. New York: Metropolitan Books, 1998.

Pela, Robert L. Filthy: The Weird World of John Waters. New York City: Alyson Books, 2002. 
Penslar, Derek Jonathan and Anthony W. Lee. Shylock's Children: Economics and Jewish Identity in Modern Europe. Berkeley and Los Angeles: University of California Press, 2001.

Peraino, Judith A. Listening to the Sirens: Musical Technologies of Queer Identity from Homer to Hedwig. Berkeley: University of California Press, 2006.

Perry, Charles. The Haight-Ashbury: A History. New York: Random House, 1984.

Peterson, Jon. A. The Birth of City Planning in the United States, 1849-1917. Baltimore, MD: The Johns Hopkins University Press, 2003.

Phillips, Lisa, ed. Beat Culture and the New America, 1950-1965. New York: Whitney Museum of Art, 1996.

Plumb, Beatrice Edgar James Helms, the Goodwill Man. Minneapolis: T. S. Denison \& Company, Inc., 1965.

Portes, Alejandro. "The Informal Sector: Definition, Controversy, and Relation to National Development," Review 7, no. 1 (1983): 151-74.

and Saskia Sassen-Koob, "Making it Underground: Comparative Material on the Informal Sector in Western Market Economies," American Journal of Sociology 93, no.1 (1987).

Manuel Castells, and Lauren A. Benton, ed., The Informal Economy: Studies in Advanced and Less Developed Countries/ Baltimore and London: The Johns Hopkins University Press, 1989.

Potter, David. People of Plenty: Economic Abundance and the American Character. Chicago: University of Chicago Press, 1954.

Pozzetta, George E. Americanization, Social Control, and Philanthropy. New York and London: Taylor and Francis, 1991.

Prato, Greg. Grunge is Dead: The Oral History of Seattle Rock Music. Toronto: ECW Press, 2009.

Price, Sandy. Exploring the Flea Markets of France. New York: Three Rivers Press, 1999.

Prochaska, F. K. "Charity Bazaars in Nineteenth-Century England," Journal of British Studies 16.2 (Spring 1977).

Prohaska, Ellen M. "The Garage Sale: A Quasi-Economic Institution”. MA thesis: Northern Illinois University, Apr 1974.

Putnam, Robert D. Bowling Alone: The Collapse and Revival of American Community. New York: Simon and Schuster Paperbacks, 2000.

Pyle, Jane. "Farmers' Markets in the United States: Functional Anachronisms," in American Geographical Society 61.2 (Apr., 1971): 167-197. 
Quart, Leonard and Albert Auster. American Film and Society Since 1945. Santa Barbara, California: Praeger, 2011.

Razzouk, Nabil Y. and David Gourley, "Swap Meets: A Profile of Shoppers," Arizona Business 29 (1982): 8-12.

Rechiutti, John Louis. Civic Engagement: Social Science and Progressive-Era Reform in New York City. Philadelphia: University of Pennsylvania Press, 2007.

Reed, Jeremy. Jean Genet: Born to Lose. London: Creation Books, 2005.

Reid, John Bevus and Ronal Michael James, eds. Uncovering Nevada's Past: A Primary Source History of the Silver State. Reno: University of Nevada Press, 2004.

Reilly, Edward G. The 1960s. Westport, CT: Greenwood Press, 2003.

Reimers, David M. "Immigrants and Thrift." In Joshua J. Yates and James Davison Hunter, eds. Thrift and Thriving in America: Capitalism and Moral Order from the Puritans to the Present. New York: Oxford University Press, 2011.

Reisman, David, Reuel Denny, and Nathan Glazer Reisman. The Lonely Crowd: A Study of the Changing American Character. New Haven and London: Yale University Press, 1950.

Renan, Sheldon. The Underground Film: An Introduction to Its Development in America. Encinitas, CA: Studio Vista Books, 1967.

Richmond, Phyllis Allen. "American Attitudes toward the Germ Theory of Disease, 18601880," Journal of the History of Medicine 9 (1954).

Ridinger, Robert B. ed., Speaking for our Lives: Historic Speeches and Rhetoric for Gay and Lesbian Rights (1892-2000). Binghamton, New York: Harrington Park Press, 2004.

Robinson, Willard B. "The Public Square as a Determinant of Courthouse Form in Texas," The Southwestern Historical Quarterly, 75.3 (January 1972): 339-372.

Roemer, Rick. Charles Ludlam and the Ridiculous Theatrical Company. Jefferson, North Carolina and London: McFarland \& Company, Inc, 1998.

Rosemont, Franklin. André Breton and the First Principles of Surrealism. London: Pluto Press, 1978.

Rufus, Anneli and Kristan Lawson. The Scavengers' Manifesto. New York: Penguin, 2009.

Saloy, Mona Lisa. "Black Beats and Black Issues," in Lisa Phillips, ed. Beat Culture and the New America, 1950-1965. New York: Whitney Museum of Art, 1996.

Said, Edward. Orientalism. New York: Vintage Books, 1979.

Sanderson, Ross Warren. The Church Serves the Changing City. New York: Harper Books, 1955 . 
Sargeant, Jack. Naked Lens: Beat Cinema. Berkeley: Soft Skull Press, 2008.

Satterthwaite, Ann. Going Shopping: Consumer Choices and Community Consequences. New Haven and London: Yale University Press, 2001.

Sauder, Robert A. "The Origin and Spread of the Public Market System in New Orleans," Louisiana, History: The Journal of the Louisiana Historical Association 22.3 (Summer, 1981): 282 .

Saul, Scott. Freedom Is, Freedom Ain't: Jazz and the Making of the Sixties. Boston: Harvard University Press, 2009.

Savage, Jon. Time Travel: Pop, Media, and Sexuality, 1976-1996. London: Chatto \& Windus, 1996.

Saville, Deborah. "Dress and Culture in Greenwich Village," In Linda Welters and Patricia A. Cunningham, Twentieth-Century American Fashion. New York: Berg, 2005 pp. 33-56.

Schatz, Eshel and Roger. Jewish Maxwell Street Stories. Chicago: Arcadia, 2004.

Schreier, Barbara A. Becoming American Women: Clothing and the Jewish Immigrant Experience, 1880-1920. Chicago: Chicago Historical Society, 1994.

Scroop, Daniel. "The Anti-Chain Store Movement and the Politics of Consumption," American Quarterly 60.4 (Dec. 2008): 925-949.

Segrave, Kerry. Drive-in Theaters: A History from Their Inception in 1933. North Carolina: McFarland and Company, Inc. Publishers, 1992.

Sealander, Judith. "Curing Evils at Their Source: The Arrival of Scientific Giving." In Charity, Philanthropy, and Civility in American History. Lawrence J. Friedman and Mark D. McGarvie, eds. New York: Cambridge University Press, 2003.

Seigal, Jerrold. Bohemian Paris: Culture, Politics, and the Boundaries of Bourgeois Life, 18301930. New York: Penguin, 1986.

Shaw, Arnold The Jazz Age: Popular Music in the 1920's. New York: Oxford University Press, 1987.

Shaw, Philip. Patti Smith's Horses. New York City: The Continuum International Publishing Group, 2008.

Shepard, Benjamin. "History, Narrative, and Sexual Identity: Gay Liberation and Postwar Movements for Sexual Freedom in the United States." In Phillip L. Hammack and Bertram J. Cohler, eds., The Story of Sexual Identity: Narrative Perspectives on the Gay and Lesbian Life Course. New York: Oxford University Press, Inc., 2009.

Shepherd, Robert J. When Culture Goes to Market: Space, Place, and Identity in an Urban Marketplace. New York: Peter Lang, 2008.

Shepard, Benjamin. "Play as World-Making: From the Cockettes to the Germs, Gay Liberation to 
DIY Community Building." In Dan Berger, ed. The Hidden 1970s: Histories of Radicalism. New Brunswick: Rutgers University Press, 2010.

Sherman, Elaine, Kevin McCrohan, and James Smith. "Informal Retailing: An Analysis of Products, Attitudes, and Expectations." In Elizabeth C. Hirschman, Morris B. Holbrook eds. Advances in Consumer Research. Provo, Utah: Association for Consumer Research, 1985.

Sherry Jr., John F. "A Sociocultural Analysis of a Midwestern American Flea Market," The Journal of Consumer Research 17.1 (June 1990): 13-30.

Shilts, Randy. The Mayor of Castro Street. New York: St. Martin’s Press, 1982.

Sheumaker, Helen. “'I Hope You Won't Mind My Writing You': Mabel Urner Harper and her antique-collecting fans," unpublished paper presented at the American Historical Association annual conference. January 2013.

Sides, Josh. Erotic City: Sexual Revoutions and the Making of San Francisco. Oxford and New York City: Oxford University Press, 2009.

Simic, Charles. Dime-Store Alchemy: The Art of Joseph Cornell. New York: New York Review Book, 1992.

Slade, Giles. Made to Break: Technology and Obsolescence in America. Boston: First Harvard University Press, 2007.

Solan, Britta Ann-Christin. The Culture of Local Food: A Life History Study of Farmers' Market Customers in a Midwest City (Iowa City: University of Iowa Press, 2002.

Sollers, Werner. Amiri Baraka/LeRoi Jones: The Quest for a “Populist Modernism.” New York City: Columbia University Press, 1978.

Soiffer, Stephen M. and Gretchen Herrmann, "For Fun and Profit: An Analysis of the American Garage Sale," Urban Life 12 (1984): 397-421.

Somers-Willett, Susan B.A. Cultural Politics of Slam Poetry: Race, Identity and the Performance of Popular Verse in America. Ann Arbor: MI: University of Michigan, 2009.

Springer, Robert ed., Nobody Knows Where the Blues Come From: Lyrics and History. Jackson, Mississippi: The University of Mississippi Press, 2006.

St. Thomas, Kurt. Nirvana: The Chosen Rejects. New York: St. Martin's Press, 2004.

Stein, Marc. Rethinking the Gay and Lesbian Movement. New York: Routledge, 2012.

Steinberg, Shirley Priya Parmar, and Birgit Richard, Contemporary Youth Culture: And International Encyclopedia, Vol 2. Westport, CT: Greenwood Press, 2006.

Stansell, City of Women: Sex and Class in New York, 1789-1860. Chicago: University of Illinois Press, 1987. 
Stansell, Christine American Moderns: Bohemian New York and the Creation of a New Century. New York: Henry Holt and Company, 2000.

Stanton, Maureen. Killer Stuff and Tons of Money: Seeking History and Hidden Gems in FleaMarket America. New York: The Penguin Press, 2011.

State, Paul F. Historical Dictionary of Brussels. Lanham, MD: Scarecrow Press, Inc, 2004.

Steele, Valerie. Fifty Years of Fashion: From New Look to Now. New Haven, CT: Yale University Press, 1997.

-------. The Berg Companion to Fashion. New York: Berg, 2010.

------. The Black Dress. New York: HarperCollins, 2007.

Stillinger, Elizabeth. The Antiquers: The lives and careers, the deals, the finds, the collections of the men and women who were responsible for changing taste in American antiques, 1850-1930. New York: Alfred A. Knopf, 1980.

Stokes, Jerry. "A Flea Market By Any Other Name Is a Flea Market," in Rupert Thomas and Eglé Salvy, Antique \& Flea Market of London \& Paris. London: Thames \& Hudson, 1999.

Strasser Susan. Waste and Want: A Social History of Trash. New York: Henry Holt and Company, 1999.

Stryker, Susan and Jim Van Buskirk, Gay By the Bay: A History of Queer Culture in the San Francisco Bay Area. San Francisco: Chronicle Books, 1996.

Stubbs, Katherine. "Reading Material: Contextualizing Clothing in the Work of Anzia Yezierska," MELUS 23.2, Varieties of Ethnic Criticism (Summer 1998): 157-72.

Sugrue, Thomas J. The Origins of the Urban Crisis: Race and Inequality in Postwar Detroit Princeton, New Jersey: Princeton University Press, 1996.

Sullivan, James. Jeans. New York City: Gotham Books, 2006.

Swiencicki, Mark A. "Consuming Brotherhood: men's Culture, Style and Recreation as Consumer Culture, 1880-1930,” Journal of Social History 31.4 (Summer 1998): 773-808.

Taiz, Lillian. Hallelujah Lads and Lasses: Remaking the Salvation Army in America, 1880-1930. Chapel Hill: University of North Carolina Press, 2001.

Talbot, David. Season of the Witch: Enchantment, Terror, and Deliverance in the City of Love. New York: Free Press, 2012.

Taminiaux, Pierre. The Paradox of Photography. New York: Editions Rodopi B.V., 2009.

Tangires, Helen. Public Markets and Civic Culture in Nineteenth-Century America. Baltimore: Johns Hopkins University Press, 2003. 
Tangires, Public Markets. New York: W \& W Norton and Company, Inc, 2008.

Tartaglia, Jerry. "The Perfect Queer Appositeness of Jack Smith” In Winston Dixon Wheeler and Gwendolyn Audrey Foster, eds. Experimental Cinema: The Film Reader. London: Routledge, 2002.

Tavel, Ronald. "Maria Montez: Anima of an Antediluvian World.” In Edward Leffingwell, Jack Smith, and Carole Kismaric, and Marvin Heiferman, eds. Flaming Creature: Jack Smith, His Amazing Life and Times. New York: Serpent's Tail, 1997.

Tehranian, Katherine. Modernity, Space, and Power: The American City in Discourse and Practice. Cresskill, NJ: Hampton Press, 1995.

Thompson, Dave. Dancing Barefoot: The Patti Smith Story. Chicago: Chicago Review Press, 2011.

Thompson, Mark. "Children of Paradise." In Corey K. Creekmur and Alexander Doty, eds. Out in Culture: Gay, Lesbian, and Queer Essays on Popular Culture. Duke University Press, 1995.

Thompson, Michael Rubbish Theory. London: Oxford University Press, 1979.

Tischler, Barbara L. Sights on the Sixties. Rutgers University Press, 1992.

Tomlinson, Sally. "Psychedelic Rock Poster: History, Ideas, and Art.” In Ann Charters, ed. The Portable Sixties Reader. New York City: Penguin Books, 2003.

Troutt, Margaret. The General Was a Lady: The Story of Evangeline Booth. Nashville: A.J. Holman, 1980.

Tucker, David M. The Decline of Thrift in America: Our Cultural Shift from Saving to Spending. New York: Praeger, 1991.

Tomes, Nancy. The Gospel of Germs: Men, Women, and the Microbe in American Life. Cambridge: Harvard University Press, 1998.

Unwin, P.T.H. Wine and the Vine. New York: Routledge, 1996.

Wagner, David. What's Love Got to Do with It? A Critical Look at American Charity. New York: New Press, 2001.

Waldman, Diane. Joseph Cornell: Master of Dreams. New York: Abrams, Inc, 2002.

Walick, M. E. Max Ernst and Alchemy: A Magician in Search of Myth. Texas: University of Texas, 2001.

Wallace, Amy and Handsome Dick Manitoba. The Official Punk Rock Book of Lists. New York: Backbeat Books, 2007.

Ward, David and Olivier Zunz, eds. Landscapes of Modernity: New York, 1900-1940.

Baltimore, MD: Johns Hopkins University Press, 1992. 
Watson, Steven. Strange Bedfellows: The First American Avant-Garde. New York: Abbeville Press Publishers, 1991.

Watson, Steven. The Birth of the Beat Generation: Visionaries, Rebels, and Hipsters, 1944-1960. New York: Pantheon Books, 1995.

Watts, Amber. "Remaking Consumer Culture." In Dana Alice Heller, ed. The Great American Makeover: Television, History, Nation. New York: Palgrave MacMillan, 2006.

Welters, Linda. “The Beat Generation.” In Linda Welters and Patricia A. Cunningham, eds. Twentieth-Century American Fashion. New York: Berg, 2005.

Weil, Steven E. and G. Daniel DeWeese. Western Shirts: A Classic American Fashion. Layton, Utah: Gibbs Smith, 2004.

Wetzsteon, Ross. Republic of Dreams: Greenwich Village, The American Bohemia, 1910-1960. New York: Simon \& Schuster, 2002.

Wilson, Elizabeth. Adorned in Dreams: Fashion and Modernity. Berkeley and Los Angeles: University of California Press, 1985.

------. Bohemians: The Glamorous Outcasts. New Brunswick, New Jersey: Rutgers University Press, 2000.

Wilson, P.W. General Evangeline Booth of the Salvation Army (NewYork: Charles Scribner's Sons, 1948),

Wilson, William H. The City Beautiful Movement. Baltimore and London: The Johns Hopkins University Press, 1989.

Williams, Susan L. and Michelle Bemiller. Women at Work: Tupperware, Passion Parties, and Beyond. Boulder, Colorado: Lynne Rienner Publications, 2011.

Winston, Diane. Red-Hot and Righteous: The Urban Religion of the Salvation Army. Cambridge, Harvard University Press, 1999.

Woloson, Wendy. In Hock: Pawning in America from Independence Through the Great Depression. Chicago: The University of Chicago Press, 2009.

Wren, David Nelson. Every First Monday: A History of Canton, Texas. Wichita Falls, Texas: Nortex Offset Publications, 1973.

Valliant, Derek. "Peddling Noise: Contesting the Civic Soundscape of Chicago, 1890-1913," Journal of the Illinois State Historical Society (vol. 96, No. 3, Autumn, 2003): 257-287.

Voguepedia. "Turning Points: Grunge," http://www.vogue.com/voguepedia/Grunge\#cite note-9 Accessed June 15, 2013.

Von Hoffman, Nicholas. We Are the People Our Parents Warned Us Against. Chicago: Quadrangle, 1968. 
Yates, Joshua J. and James Davison Hunter, eds. Thrift and Thriving in America: Capitalism and Moral Order from the Puritans to the Present. New York: Oxford University Press, 2011.

Young, Rob. Electric Eden: Unearthing Britain's Visionary Music. New York: Faber and Faber, Inc., 2010.

Young, William H. with Nancy K. Young, The 1950s. Westport, CT: Greenwood Press, 2004.

York, Peter. Modern Times (London: Futura, 1980

Zarefsky, David. President Johnson's War on Poverty: Rhetoric and History. Tuscaloosa, Alabama: University of Alabama Press, 2005.

Zimmerman, Bonnie, ed. Encyclopedia of Lesbian and Gay Histories and Cultures. New York: Garland Publishing, 2000.

Zimring, Carl Cash for Your Trash: Scrap Recycling in America. New Brunswick, N.J.: Rutgers University Press, 2000.

--------“Dirty Work: How Hygiene and Xenophobia Marginalized the American Waste Trades, 1870-1930," Environmental History 9.1 (January 2004).

Zunz, Olivier. Philanthropy in America: A History. Princeton: Princeton University Press, 2012.

"Mass Philanthropy as Public Thrift for an Age of Consumption," in Yates and Hunter, eds. Thrift and Thriving in America: Capitalism and Moral Order from the Puritans to the Present. New York: Oxford University Press, 2011. pp. 336-38 